\author{
Universidade de São Paulo \\ Faculdade de Medicina de Ribeirão Preto
}

Tiago Mauricio Francoy

Variabilidade genético-morfológica em populações Neotropicais de Apis mellifera.

Ribeirão Preto

2007 
Tiago Mauricio Francoy

\section{Variabilidade genético-morfológica em populações Neotropicais de Apis mellifera.}

Tese apresentada à Faculdade de Medicina de Ribeirão Preto para Obtenção do Título de Doutor em Ciências

Área de Concentração: Genética Orientador: Prof. Dr. Lionel Segui Gonçalves

Ribeirão Preto

2007 


\section{AUTORIZO A DIVULGAÇÃO TOTAL OU PARCIAL DESTE TRABALHO, POR QUALQUER MEIO CONVENCIONAL OU ELETRÔNICO, PARA FINS DE ESTUDO E PESQUISA, DESDE QUE CITADA A FONTE.}

\section{FRANCOY, TIAGO MAURICIO}

Variabilidade genético-morfológica em populações Neotropicais de Apis mellifera. Tiago Mauricio Francoy; orientador: Lionel Segui Gonçalves-Ribeirão Preto, 2007.

158p.: 46 il.

Tese de Doutorado, apresentada à Faculdade de Medicina de Ribeirão Preto/USP - Departamento de Genética.

1. Apis mellifera. 2. Morfometria de asa. 3. DNA mitocondrial. 4. Variabilidade Populacional. 5. Identificação individual e populacional. 


\section{Folha de Aprovação}

Tiago Mauricio Francoy

Variabilidade genético-morfológica em

populações Neotropicais de Apis mellifera

Tese apresentada à Faculdade de Medicina de Ribeirão Preto para Obtenção do Título de Doutor em Ciências

Área de Concentração: Genética

Aprovado em:

Banca Examinadora

Prof. Dr.

Instituição:

Assinatura

Prof. Dr.

Instituição:

Assinatura

Prof. Dr.

Instituição:

Assinatura

Prof. Dr.

Instituição:

Assinatura

Prof. Dr.

Instituição:

Assinatura 


\section{Dedico}

À minha família e aos meus amigos, em especial aos meus pais, Vitor e Rosa, meus irmãos, Vitor, Sandra e Lucas e aos meus "irmãos molarianos", Fernando (Fernandex), Saulo (Saulinho), Rodrigo Ivo (Doidinho), Rodrigo Anselmo (Smoo), Leandro (Leandrão), Rogério (Wimbe), José Luiz (Zézim) e Anderson (Homer) por se tornarem a base da minha força e dedicação ao longo dos anos. Nada disso teria sido possível sem vocês. 


\section{Agradecimentos}

É difícil, e muitas vezes injusto, externar em palavras sentimentos de qualquer natureza, pois nem sempre as palavras conseguem expressar a intensidade real dos mesmos. Entretanto, é ainda mais injusto deixar de expressar estes sentimentos, de modo que vou tentar, dentro de minhas limitações, demonstrar meu carinho e agradecimento a todas as pessoas que ajudaram ou participaram de alguma forma deste trabalho ou da minha vida durantes estes anos

$>$ Ao Prof. Dr. Lionel Segui Gonçalves, pela oportunidade oferecida e pela orientação em todos os momentos de minha vida acadêmica, sempre disposto a ajudar, mas principalmente pela imensa amizade e carinho dispensados. Um segundo pai pra mim;

$>$ Ao Prof. Dr. Dieter Wittmann, que tão bem me acolheu em sua casa e em seu instituto em Bonn - Alemanha, por toda a ajuda e amizade desprendidos;

$>\quad$ À Prof ${ }^{a} \operatorname{Dr}^{a}$ Zilá L. P. Simões e à Prof ${ }^{a} \operatorname{Dr}^{a}$ Márcia Bitondi, meus agradecimentos especiais por terem me incluído no projeto temático da Fapesp e em seu grupo de pesquisa, o que permitiu o desenvolvimento da parte molecular do presente trabalho;

$>\quad$ Ao Prof. Dr. David de Jong, por todos os ensinamentos, auxílio e amizade durante todos estes anos de trabalhos em conjunto;

$>$ Ao Prof. Dr. Klaus Hartfelder e Prof. Dr. Ademilson Soares, pela convivência e amizade;

$>\quad \grave{A}$ Prof $^{\mathrm{a}} \operatorname{Dr}^{\mathrm{a}}$ Érika Hingst Zaher, pelo auxílio com as análises de morfometria geométrica;

> À minha Família Científica, a "Família Gonçalves", Michelle, Rogério, Gesline, Vanessa, Marina e aos mais novos, mas não menos importantes Daiana e Francisco: o MELHOR grupo de trabalho que uma pessoa pode encontrar;

> À Patrícia Nunes Silva, grande amiga e companheira de horas boas e ruins, por todo o carinho e dedicação durantes todos estes anos; 
À Ana Durvalina Bomtorin (Tita), amiga presente em todos os momentos, sempre disposta a ajudar sem pedir nada em troca;

> Às outras três integrantes do quarteto fantástico, Micheli Beccari (Tia), Mariana do Valle (Hema) e Marina Fonseca (Skol) por sempre estarem lá, pro que der e vier;

> Ao Prof. Dr. Patrício Maracajá da UFERSA - Mossoró e ao Sr. Valdemar Belchior Filho do Sebrae - RN pelas amostras cedidas para análise;

> À Marcela B. F. Laure, pelo auxílio com as milhares de asas, todas montadas com muito bom humor e risadas;

> À Adriana M. Nascimento e à Vera Lucia Castelo Figueiredo, pelos incontáveis géis e polímeros, mas principalmente pela amizade e carinho;

> À minha querida amiga Renata Andrade Cavallari, sempre presente e disposta. Não sei o que faria sem você;

> Aos companheiros de Bloco A, Érica, Fernanda, Ana Paula, Anete, Karina, Roberto Barchuk, Alexandre Cristino, Paulo Emílio, Amanda, Weyder, Aline Mackert, Juliana, Mônica, Francis, David, Ana Bonetti, Liliane, Moysés, Michelle Prioli, Umberto Moreno, Omar, Ivan, Rodrigo, Ana Rita, Camila e Sérgio;

$>$ Aos queridos amigos que fiz na Alemanha, mais uma "Família", Fernando, Rebeca, Aline, Michelle, Jaqueline, Pedro, Rheinaldo, Bernhard, Guilherme, Maria Teresa, Anika, Stephan e Lasic por fazerem meu ano de estágio inesquecível, um dos melhores de toda a minha vida;

$>$ Aos amigos da $36^{\mathrm{a}}$ turma de Ciências Biológicas da USP Ribeirão Caroline Cunha (Carol), Andréia Barbosa (Déia), Maíra Sousa (Má), Danielle Guimarães (Dani), Carlos Lobo (Carlitos) e Fernando Franco (Fernandex), amigos pra sempre;

$>$ Aos amigos do Institut für Nutzplfanzenwissenschaften und Ressourcenschutz, Jessica, Andreé, Mathias, Jens, Markus, Muhammad, Moses, Josué, Flora, Uwe, Viola, Marie Rose, Ingrid, Christiane, Dete e Christa por terem me acolhido nos abelhudos de Bonn; 
Aos amigos do Institu für Informatik III, Prof. Dr. Volker Steinhage, Martin Drauschke, Stephan Müller e Stephan Schröder pelo auxílio com o software ABIS e pelos melhoramentos alcançados juntos;

Aos meus pais, irmãos e familiares, Vitor, Rosa, Vitor, Sandra Mara, Pedro Henrique, João Lucas (que ainda não chegou, mas que já ta encomendado), Sandra Renata, Lucas e Jeanne, que são a melhor de todas as famílias;

$>$ Um agradecimento especial à família Wittmann, Mônica, Steffi e Pascal, que tão bem me acolheram em seu lar e tornaram minha adaptação à Alemanha muito mais fácil;

$>\quad$ Ao Prof. Dr. Stephan Fuchs, Prof. Dr. Connal Eardley e Prof ${ }^{a}$ Dr $^{a}$ Maria Cristina Arias pelo envio de amostras e dados fundamentais para a realização deste trabalho;

$>$ Aos técnicos do nosso laboratório, João José dos Santos, Adelino Penatti, Luiz Roberto Aguiar, Jairo de Souza e Roberto Mazucatti, pela amizade e auxílios prestados;

$>$ À CAPES, pelo apoio financeiro durante o período do doutorado e pela oportunidade de cursar parte deste processo na Alemanha, uma experiência sem igual;

$>$ À FAPESP, pela bolsa outorgada graças a qual iniciei meus estudos em biologia molecular;

A todas as pessoas que de alguma maneira fizeram parte da minha vida nestes últimos anos, pois todas as pessoas que passam deixam um pouco de si mesmas e também levam um pouco de nós, tornando únicos cada um de nós.

A todos vocês, o meu muito obrigado 


\section{Tocando em Frente}

Composição: Almir Sater e Renato Teixeira

Ando devagar porque já tive pressa; e levo esse sorriso porque já chorei demais

Hoje me sinto mais forte, mais feliz quem sabe; Só levo a certeza de que muito pouco eu sei, ou nada sei..

Conhecer as manhas e as manhãs; o sabor das massas e das maçãs

É preciso amor pra poder pulsar; É preciso paz pra poder sorrir

É preciso a chuva para florir.

Penso que cumpri a vida seja simplesmente; compreender a marcha ir tocando em frente como um velho boiadeiro levando a boiada eu vou tocando os dias

pela longa estrada eu vou, estrada eu sou

Conhecer as manhas e as manhãs; o sabor das massas e das maçãs

É preciso amor pra poder pulsar; É preciso paz pra poder sorrir

É preciso a chuva para florir

Todo mundo ama um dia, todo mundo chora, um dia a gente chega no outro vai embora

Cada um de nós compõe a sua história, cada ser em si carrega o dom de ser capaz e ser feliz

Conhecer as manhas e as manhãs; o sabor das massas e das maçãs

É preciso amor pra poder pulsar; É preciso paz pra poder sorrir

É preciso a chuva para florir

Ando devagar porque já tive pressa; levo esse sorriso porque já chorei demais

cada um de nós compõe a sua história; cada ser em si carrega o dom de ser capaz

de ser feliz 


\section{Resumo}

Desde o início do processo de africanização das abelhas Apis mellifera nas Américas em 1957, as abelhas africanizadas têm sido alvo de muitos estudos, sendo a variabilidade populacional um destes focos. Neste trabalho, populações Neotropicais de Apis mellifera do Brasil e do Panamá foram avaliadas quanto a sua variabilidade morfológica por morfometria tradicional, morfometria geométrica e pelo software de identificação automática de abelhas ABIS (Automatic Bee Identification System). Foram ainda avaliadas quanto à origem do DNA mitocondrial encontrado atualmente nas populações, bem como mudanças temporais nos perfis morfométricos e de DNA mitocondrial nas populações de Ribeirão Preto e do Panamá. Os resultados mostram que as populações brasileiras amostradas apresentam um gradiente de variação de tamanho, sendo que as abelhas do sul são significantemente maiores que as do norte do país, assim como as abelhas do princípio do processo de africanização em Ribeirão Preto e no Panamá são maiores que as populações atuais. Essas diferenças de tamanho podem refletir diferentes graus de mistura das populações ancestrais e também fatores ecológicos e ambientais. Entretanto, nenhuma correlação significante foi encontrada entre as medidas de tamanho de asa e altitude da localidade amostrada, fato este que nos indica que em nossas amostras, a variável altitude não interferiu no tamanho das asas das abelhas. No que diz respeito à variabilidade do formato das nervuras das asas das abelhas africanizadas, esta se mostra pequena e, apesar de distinto do formato de Apis mellifera scutellata, o formato das nervuras das abelhas africanizadas é mais parecido com o destas abelhas do que das demais subespécies formadoras do híbrido. O DNA mitocondrial das populações brasileiras de abelhas africanizadas apresentou-se quase que totalmente como sendo de origem africana à exceção de três colônias que apresentaram DNA mitocondrial como sendo de origem de subespécies do leste europeu. Quando a morfometria geométrica e o ABIS foram testado no quesito identificação populacional, ambos mostraram um desempenho muito fraco em identificar as populações de abelhas africanizadas, provavelmente devido ao alto fluxo gênico entre os grupos. Entretanto, quando tratamos de grupos mais distantes, como 
subespécies e populações isoladas, como é o caso da população de abelhas italianas $(A . m$. ligustica) de Fernando de Noronha, os dois métodos morfométricos se mostraram muito eficientes, com as taxas de acerto girando entre $85 \%$ e $100 \%$ na identificação de colônias de diferentes subespécies e da população de Fernando de Noronha. A população de Fernando de Noronha apresentou ainda um perfil morfométrico completamente diferenciado de Apis mellifera ligustica, subespécie que foi introduzida na ilha em 1984, podendo estas diferenças serem resultado de inbreeding, adaptação ambiental ou mesmo efeito gargalo das matrizes introduzidas. Desta maneira, as novas metodologias morfométricas utilizadas neste trabalho, embora não sejam precisas ou as mais apropriadas para identificar o grau de africanização das populações de abelhas africanizadas, se mostram muito promissoras no estudo da identificação das subespécies de Apis mellifera e mesmo de outras espécies de abelhas. 


\begin{abstract}
Since the release of the African bee Apis mellifera scutellata in Brazil in 1957, Africanized honey bees have been widely studied, though there are still unresolved questions about population variability. We examined the temporal and spatial variability of Apis mellifera populations from Brazil and Panama, using mitochondrial DNA, traditional morphometrics, geometric morphometrics and an Automatic Bee Identification System (ABIS). The populations from Ribeirão Preto, Brazil and Panamá were examined for temporal changes in their morphometric profiles and in mitochondrial DNA patterns. Bees from south Brazil were found to be significantly larger than those from the north and northeast. Bees collected at the beginning of the Africanization process were also found to be bigger than those collected recently. These differences in size may reflect different degrees of admixture of the founder subspecies and also environmental and ecological factors. No significant correlation was observed between the size of the wings and the altitude where the bees were sampled. When the patterns of wing venation were compared among the Africanized populations, we found little variation; though Africanized bees were found to be distinct from (African) A. m. scutellata, this group was most similar to the African pattern. The mtDNA of the Africanized populations was found to be almost completely of African origin, except for three of 394 colonies, which had the east European pattern. This nearly complete displacement may have been caused by nest usurpation by Africanized bees or due to a competitive disadvantage of hybrids with European maternity. We did not get good discrimination or identifications of the populations with ABIS and geometric morphometrics, probably due to the high rates of gene flow among the groups. However, when tested in more distinct groups, for example, subspecies and isolated populations, such as the Italian bees on Fernando de Noronha island, these two methods were very efficient, with identification rates of around $85 \%$ and $100 \%$, respectively. The population of Italian bees (A.m. ligustica) on Fernando de Noronha presented a morphometric profile very different from that of $A$. m. ligustica, the subspecies introduced to the island in 1984. These differences could be a result of inbreeding, environmental
\end{abstract}


adaptations or bottleneck effects. The two new morphometric methodologies, though they did not provide good discrimination of the Africanized populations, are very promising for studies of Apis mellifera subspecies and for identification of other bee species. 


\section{Lista de abreviaturas}

Amm - Apis mellifera mellifera

Aml - Apis mellifera ligustica

Amc - Apis mellifera carnica

Ams - Apis mellifera scutellata

AJ - Aracaju/SE

$\mathrm{AL}$ - Alegrete/RS

$\mathrm{AQ}$ - Aquidauana/MS

$\mathrm{AR}$ - Araripina/PE

$\mathrm{BA}$ - Baraúna/RN

BE - Belém/PA

$\mathrm{CB}-$ Curitiba/PR

CR - Catolé do Rocha/PB

CT - Crato/CE

FL - Florianópolis/SC

FO - Fortaleza/CE

MA - Maringá/PR

MO - Mossoró/RN

PI - Picos/PI

PA - Porto Alegre/RS

RP - Ribeirão Preto/SP

RJ - Rio de Janeiro/RJ

SA - Salvador/BA

$\mathrm{SE}$ - Serra do Mel/RN

SEM - Severiano Mello/RN

SJ - São João da Boa Vista/SP

SL - São Luis/MA

SM - Santa Maria/RS

TU - Tucano/BA 


\section{Índice}

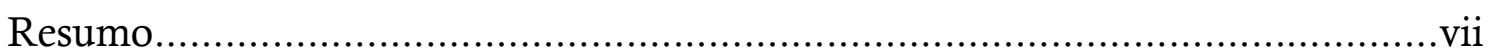

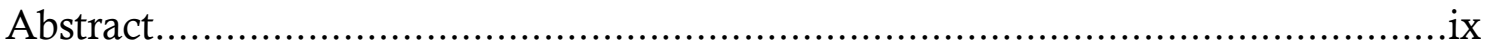

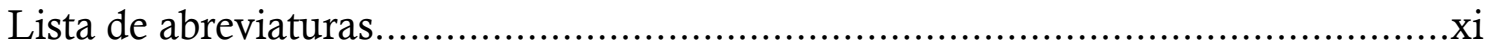

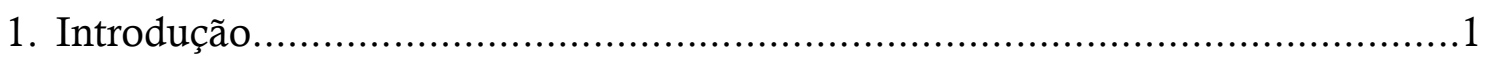

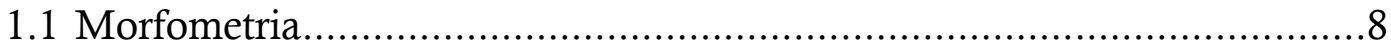

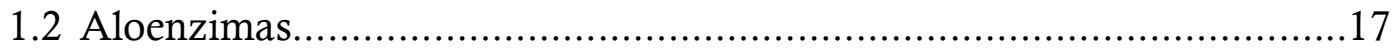

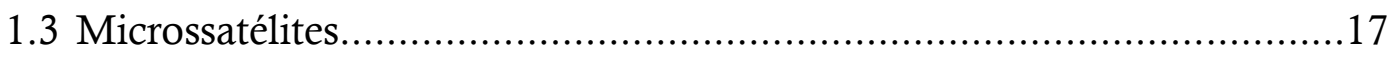

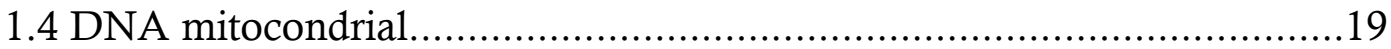

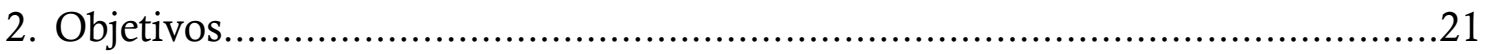

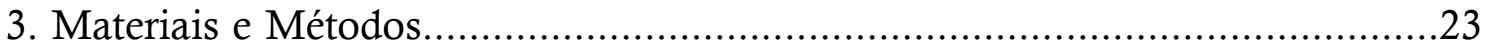

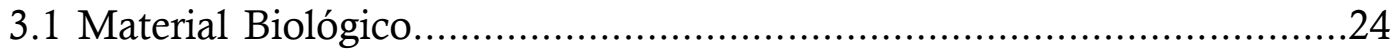

3.2 Montagem das asas e captura das imagens..........................................26

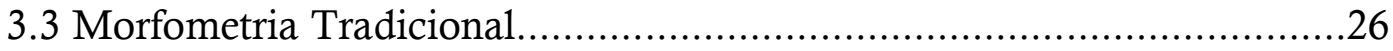

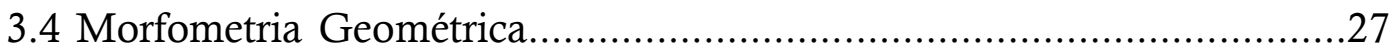

3.5 J - ABIS (Automatic Bee Identification System)........................28

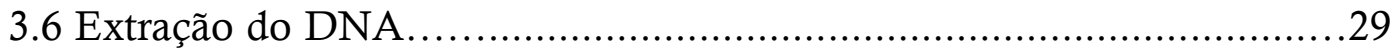

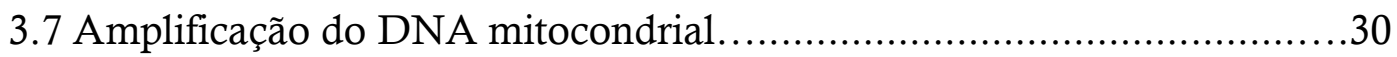

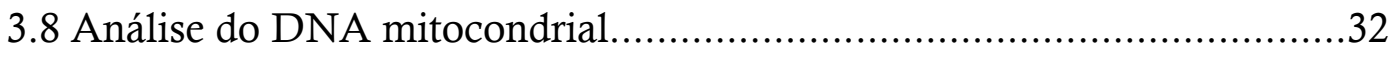

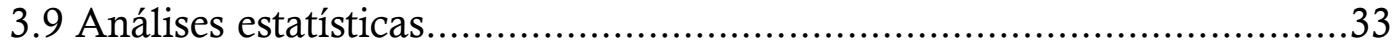

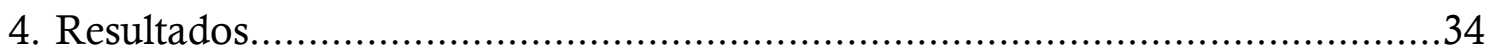

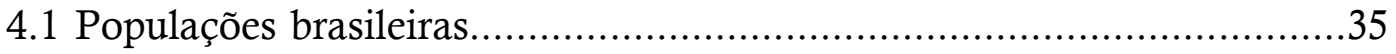

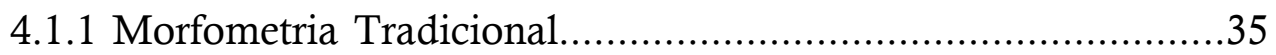

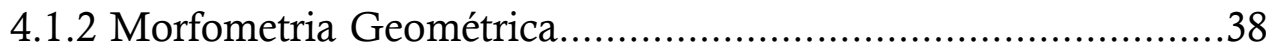

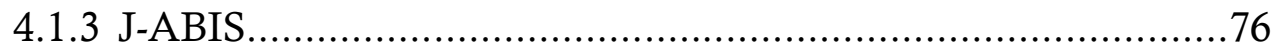

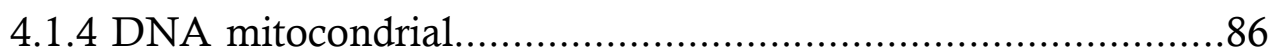

4.2 Mudanças na população de Ribeirão Preto - SP entre 1968 e 2002 ..........87

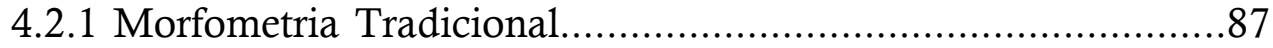

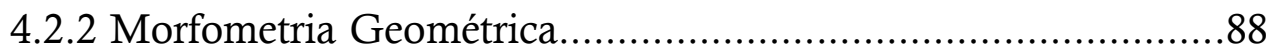

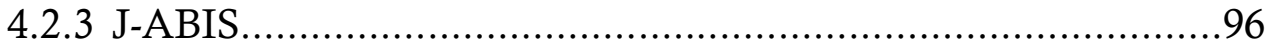

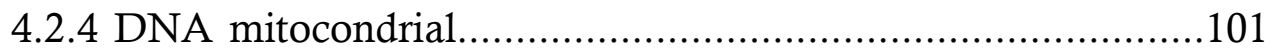


4.3 Mudanças na população do Panamá entre os anos de 1982 e 2006........101

4.3.1 Morfometria Tradicional.................................................101

4.3.2 Morfometria Geométrica...............................................102

4.3.3 J-ABIS ............................................................. 111

4.3.4 DNA mitocondrial.................................................... 117

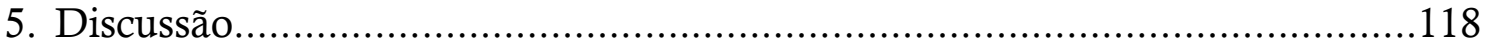

6. Conclusões e Considerações Finais..........................................................139

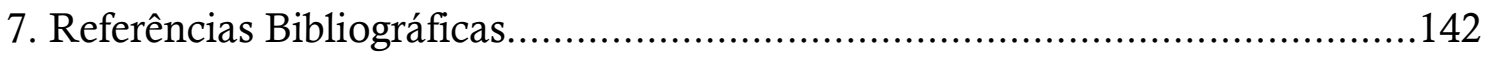


fet

Introdução 
Em sua distribuição autóctone, as abelhas Apis mellifera estão geograficamente espalhadas por grandes partes dos continentes africano e europeu e em parte da Ásia ocidental (Ruttner, 1988). Ao longo desta área, elas ocupam os mais variados ambientes, como desertos, florestas tropicais, altas montanhas e savanas entre outros (Smith, 1961). A grande diversidade de ambientes ocupados está também diretamente associada a uma grande diversificação dentro da espécie, que atualmente é dividida em pelo menos 26 subespécies (Ruttner, 1992; Sheppard et al., 1997; Sheppard \& Meixner, 2003), cada uma delas apresentando um conjunto particular de características comportamentais e muito bem adaptadas aos mais variados ambientes.

As diversas sociedades humanas presentes nas áreas de ocorrência destas abelhas sempre as exploraram como fonte de alimento, utilizando-se normalmente da subespécie presente próximo à sua área de ocorrência.

Em verdade, desde os tempos da pré-história, o homem explora os recursos oferecidos pelas abelhas melíferas. Os registros mais antigos são as pinturas rupestres datadas de aproximadamente 7000 anos encontradas na Caverna das Aranhas, em Valencia - Espanha (Crane, 1999), onde são encontradas gravuras de pessoas coletando material em colméias selvagens instaladas em árvores e frestas de rocha. De fato, quando analisada em detalhes, toda a existência do homem, que de alguma forma foi documentada, demonstra o quanto este inseto foi, e ainda é, importante para a humanidade. Histórias grafadas em paredes egípcias da época dos faraós mostram apicultores a trabalhar utilizando-se de técnicas que são praticadas até os dias atuais naquele país. A representatividade das abelhas era tão grande para aquela civilização que as abelhas eram o símbolo do bem estar e um hieróglifo de abelha era o símbolo do reino do Egito Superior antes da unificação dos reinos (Figura 1). Acreditava-se ainda que as abelhas surgissem na terra a partir das lágrimas do Deus Rá (Wilkinson, 1992). Na Grécia Antiga, tamanha era a importância das abelhas que elas eram cunhadas nas moedas de "Tetradracme" (Figura2) (Gonçalves, 1975). Outras diversas gravuras e ornamentos relacionados com abelhas, sua criação e exploração pelo homem podem ser encontradas ao longo dos anos, ressaltando a 
importância da apicultura na história humana. O atual status da apicultura mundial leva à exploração quase todos os recursos que podem ser oferecidos pelas abelhas, como polinização, mel, geléia real, cera, veneno e própolis entre outros (Gonçalves, 2004).

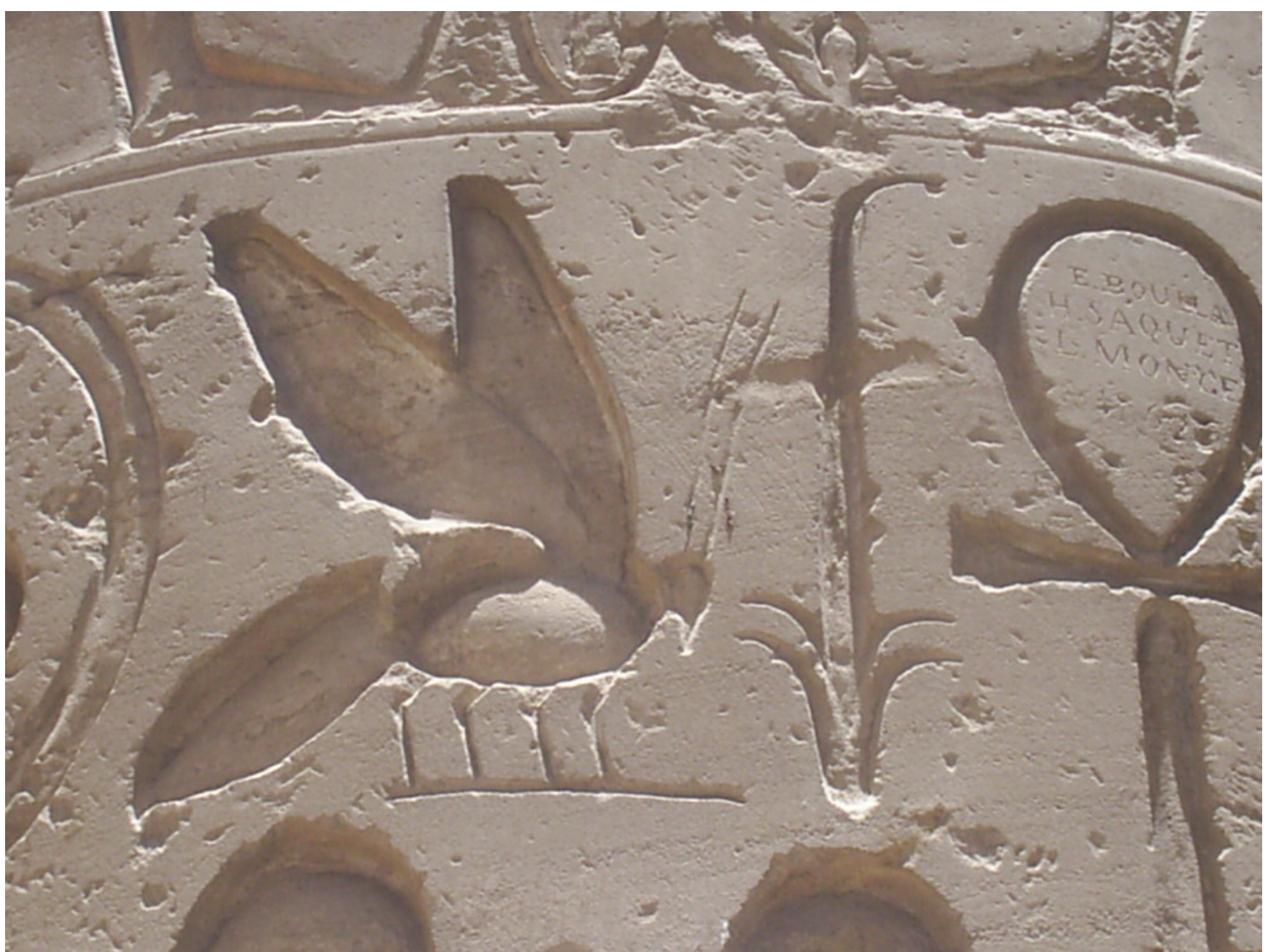

Figura 1: Hieróglifo de abelha símbolo do Egito superior e do bem estar no Egito Antigo. (Foto: Tiago Mauricio Francoy)

Com o advento da expansão européia e a colonização das novas terras descobertas, estas abelhas, que a princípio ocupavam somente o Velho Mundo, foram introduzidas em locais onde originalmente não existiam. As primeiras introduções documentadas nas Américas datam do século XVIII com a introdução de colméias da Europa Ocidental, provavelmente de $A$. m. mellifera nos Estados Unidos (Ruttner, 1992). Em terras brasileiras, elas primeiro foram introduzidas em 1839, quando o Reverendo Antônio Carneiro mandou vir da Europa colméias de A. m. mellifera. Com a introdução destas abelhas, além do objetivo de se produzir mel, pretendia-se utilizar a cera branca produzida por elas para a fabricação de velas para fins religiosos, uma vez que a cera produzida pelas abelhas sem ferrão nativas é de cor amarronzada, por ser uma mistura de cera e resinas, entre outros 
produtos. Primeiramente foram introduzidas nove colméias, sendo que destas, duas pereceram. Ao final do primeiro ano o numero de colméias já era de 50 e ao final do ano seguinte, mais de duzentas, que foram então entregues aos cuidados do governo local (Nogueira-Neto, 1972). Durantes os anos seguintes, com a chegada de mais imigrantes, foram também introduzidas no Brasil as subespécies A. m. ligustica, A. m. carnica e A. $m$. caucasica entre outras, sendo as duas primeiras, juntamente com A. m. mellifera as principais subespécies européias introduzidas em nossas terras (Gonçalves, 1994).

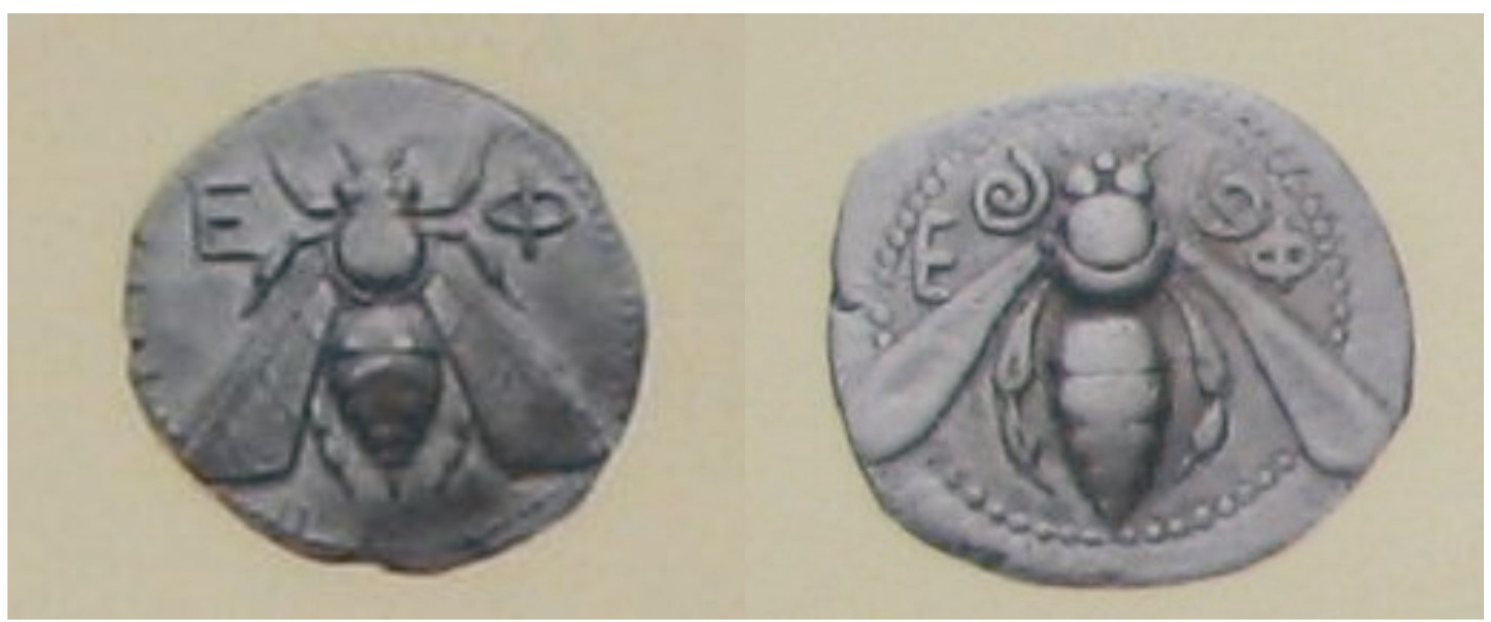

Figura 2: Moedas de "Tetradracme" da Grécia Antiga cunhadas com a imagem de abelhas. (Fotos: Tiago Mauricio Francoy)

Desta maneira, até o ano de 1956, somente as subespécies européias haviam sido introduzidas no Brasil. Entretanto, na década de 50, agências apícolas, órgãos governamentais, apicultores e cooperativas manifestaram seu descontentamento com a baixa produtividade das abelhas pretas $(A$. m. mellifera $)$ em nosso país, bem como também com a dificuldade de "italianizar" nossas abelhas (Kerr, 1967). Após uma extensa busca na literatura apícola mundial, foram encontrados relatos de um apicultor da África do Sul chamado E. A. Schnetler que conseguia médias anuais que giravam em torno de $70 \mathrm{~kg}$ de mel por colméia utilizando-se da subespécie até então conhecida como $A$. $m$. adansonii (Kerr \& Portugal-Araújo, 1958) que teve seu nome mudado para A. m. scutellata (Ruttner et al., 1978). No ano de 1956, o então eminente geneticista Prof. Dr. Warwick Estevan Kerr foi contemplado com o Prêmio Nacional de Genética "André Dreyfus", o que possibilitou sua viagem ao continente africano de agosto a dezembro de 1956 com o intuito de que 
rainhas da referida subespécie fossem importadas para o Brasil. Dentre todas as rainhas que foram trazidas para o Brasil, 48 sobreviveram, sendo que destas, 26 eram consideradas "as mais produtivas e trabalhadeiras" que o autor já tinha visto até então (Kerr, 1957). Destas, 35 colônias foram transportadas para uma floresta de Eucalipto no Horto de Camacuã, nas proximidades da cidade de Rio Claro - SP para a realização de testes e cada uma das colônias teve sua entrada protegida por uma tela excluídora de rainhas. Um apicultor visitante retirou as telas e quando os pesquisadores tomaram conhecimento do fato, enxames de 26 colônias já haviam abandonado o local, estabelecendo-se então como colônias selvagens (Kerr, 1967). Iniciou-se então uma rápida expansão das abelhas para todas as direções no Brasil, realizando cruzamentos com as subespécies européias préintroduzidas, que eram mantidas principalmente em apiários, resultando em um polihíbrido (Kerr, 1967) que foi posteriormente chamado de abelha africanizada (Gonçalves, 1974). Nestes híbridos predominaram principalmente as características da subespécie africana como uma alta capacidade enxameatória, alta produtividade, forte comportamento defensivo e uma alta adaptabilidade. Todas estas características aliadas ajudaram as abelhas africanizadas a rapidamente se estabelecer como populações silvestres nas regiões Neotropicais (Lobo \& Krieger, 1992).

Devido principalmente a sua alta capacidade enxameatória e às condições favoráveis que estas abelhas encontraram nos territórios Neotropicais, elas rapidamente se espalharam pelas Américas (Figura 3), colonizando o Brasil em 15 anos (Taylor, 1977) e, subsequentemente, quase toda a América do Sul, excetuando-se as regiões abaixo do paralelo $35^{\circ}$ na Argentina, onde o limite foi provavelmente imposto pelas baixas temperaturas de inverno encontradas nesta região (Kerr et al., 1982; Sheppard et al., 1999). Ao oeste, sua expansão foi limitada pela presença da Cordilheira dos Andes, que provavelmente impediu a passagem dos enxames devido às baixas temperaturas encontradas nas montanhas. Graças às Cordilheiras, o Chile é o único país da América do Sul que não apresenta abelhas africanizadas em seu território até a presente data (Del Lama et al., 2004). A América Central foi rapidamente colonizada, mesmo com as 
tentativas frustradas de se criar barreiras que impedissem o avanço dos enxames na região do Panamá (Boreham \& Roubik, 1987). Os primeiros enxames africanizados em território panamenho foram encontrados no ano de 1982 (Roubik, 1982) e se espalharam pelo país, e, mesmo com as campanhas educacionais feitas pelos governos norte-americano e panamenho para a população e com a eliminação de mais de 1000 colônias na área do Canal do Panamá, as abelhas continuaram seu caminho rumo ao norte do continente (Boheram \& Roubik, 1987). Uma outra tentativa de se barrar o avanço das abelhas foi feita no istmo de Tehuantepec no México no ano de 1986 (Loper \& Danka, 1991) e mais uma vez as abelhas passaram tranquilamente pelas barreiras, sendo que os primeiros enxames de abelhas africanizadas foram encontrados nos EUA em 1990 (Rinderer et al., 1993a). Atualmente, já ocupam grande parte ou a totalidade dos estados do Texas, Califórnia, Arizona, Novo México e Nevada no sul dos Estados Unidos (Pinto et al., 2007). Seu limite ao norte, embora em uma velocidade muito menor do que a registrada nas regiões de clima tropical (350 a $500 \mathrm{~km} / \mathrm{ano}$ ) (Michener, 1975), continua em expansão, com as abelhas lentamente migrando mais para o norte (Pinto et al., 2007). 


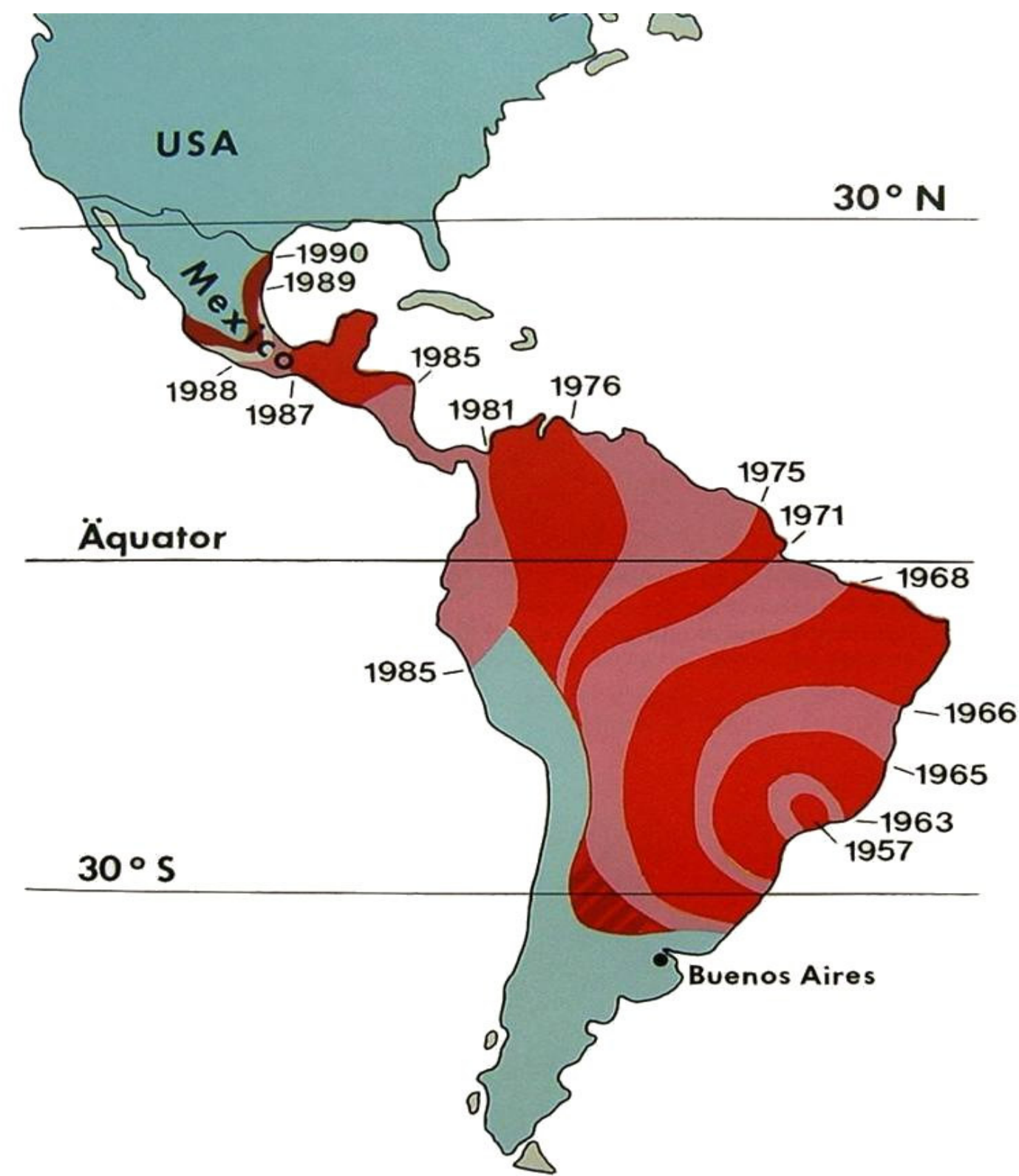

Figura 3: Mapa mostrando a expansão das abelhas africanizadas ao longo do continente americano. Os círculos coloridos indicam o ano em que os enxames foram encontrados nas regiões (Ruttner, 1992).

Como a nova abelha que se formara era um híbrido, muito pouco ou quase nada se sabia sobre seus hábitos e sua biologia à época de sua formação. Os primeiros estudos feitos com abelhas africanizadas foram voltados principalmente à sua biologia (Kerr et al., 1967), morfologia de indivíduos provenientes de cruzamentos entre as subespécies (Gonçalves, 1970) e comportamento defensivo das colônias resultantes destes cruzamentos (Stort, 1972). 
A identificação e a procura por marcadores morfológicos e genéticos que pudessem distinguir tais abelhas, bem como a identificação do grau de africanização das populações foram preocupações constantes durante os primeiros trabalhos com estas abelhas. Para tanto, diversos marcadores vem sendo propostos, sejam morfológicos ou bioquímicos ou moleculares:

\section{1 - Morfometria.}

Os primeiros trabalhos com morfometria de abelhas remontam ao início do século passado, quando Cochlov (1916) (apud Ruttner, 1988) mediu o comprimento de língua em seis raças geográficas de $A$. mellifera utilizando três colônias por raça e pelo menos 100 abelhas por colméia. Após este trabalho, uma série de outros foi realizada (Michailov, 1924, 1926; Alpatov, 1925, 1929; Skorikov, 1929) (apud Ruttner, 1988) com a constatação de um aumento no comprimento médio da probóscide das populações, do norte para o sul ao longo das planícies russas. Goetze (1940) propôs uma enorme gama de medidas que poderiam ser utilizadas para a discriminação de subespécies de $A$. mellifera. No Brasil, Gonçalves (1970) realizou uma série de cruzamentos e retrocruzamentos entre $A$. $m$. ligustica e $A$. m. scutellata tomando diversas medidas do corpo todo das abelhas resultando no primeiro trabalho brasileiro com morfometria de abelhas italianas, africanizadas e seus híbridos. Seus dados indicam uma dominância em termos genético-morfológicos apresentada pelas abelhas africanizadas sobre a subespécie européia estudada na ocasião. Entretanto, todos estes trabalhos se utilizavam principalmente de morfometria univariada, levando em consideração somente uma medida de cada vez, o que dificultava o uso destas medidas como fator discriminante de grupos, uma vez que estas medidas se sobrepunham em diversos intervalos, dificultando uma identificação precisa. Foi somente a partir do trabalho de DuPraw (1964, 1965a,b), que se iniciou o uso das técnicas de análises estatísticas multivariadas, como Análise de Componentes Principais e Análises Discriminantes, que uma identificação mais precisa começou a ser possível. Nestes 
mesmos trabalhos, DuPraw (1965a) propõe também o uso de medidas que sejam independentes de tamanho, como ângulos entre as junções de nervura da asa, uma vez que estas medidas não seriam afetadas por efeitos ambientais, como escassez de alimentos, parasitoses etc.

Assim, seguindo as análises propostas por DuPraw, Friederich Ruttner inicia uma série de trabalhos que culminam com a publicação de um guia de medidas necessárias para se discriminar as subespécies de $A$. mellifera (Ruttner et al., 1978). Neste trabalho são propostas aproximadamente 40 medidas, que deveriam ser tomadas de pelo menos 20 abelhas por colméia de determinada população para que se pudesse ter uma boa confiabilidade na indicação da procedência destas abelhas.

Desta maneira, temos uma grande diversificação dos trabalhos com morfometria de abelhas, passando desde trabalhos simples de identificação, como o proposto por Daly \& Baling (1978), que utilizava 25 medidas de diversas partes do corpo das abelhas com o intuito de discriminar abelhas africanizadas e européias, até grandes trabalhos de biogeografia, onde foram primeiramente propostas as linhagens evolutivas das subespécies de $A$. mellifera (Ruttner et al., 1978; Ruttner, 1988), que mais tarde foram confirmadas por outros marcadores, como microssatélites (Estoup et al., 1995) DNA mitocondrial (Franck et al., 2000) e mutações pontuais no DNA (Whitfield et al., 2006).

Com o advento da maior facilidade de acesso a computadores, ficou cada vez mais evidente a necessidade de se digitalizar as medições e análises, ganhando-se muito em tempo dispendido para a realização das medidas e também em termos de precisão. Em 1982, Daly et al., desenvolveram um sistema de medidas acoplado a um microcomputador, o que tornava a tomada de dados e o restante das análises muito mais rápidos e fáceis. Em 1986, Rinderer et al. desenvolveram o FABIS (Fast Africanized Bee Identification System), um método rápido, que consistia na medição de células de cria e comprimentos de algumas partes do corpo das abelhas, como asas anteriores, fêmur e trocanter. De acordo com os autores, as amostras africanizadas eram identificadas com uma probabilidade de $99 \%$ ou 
mais. Atualmente, devido aos avanços computacionais, a gama possível de medidas aumentou muito, bem como sua precisão. Posteriormente as subespécies de $A$. mellifera, incluindo as abelhas africanizadas, passaram a ser identificadas a partir de uma única célula radial com altas probabilidades de acerto (Francoy et al., 2006a).

Uma das questões que também foi respondida com o auxílio da morfometria estava relacionada a dificuldade na identificação das abelhas africanizadas devido à enorme similaridade das abelhas africanizadas com seu ancestral africano A. m. scutellata. De acordo com as medidas propostas por Daly e Baling (1978) para identificar as abelhas africanizadas, foi possível distinguir claramente entre amostras de abelhas africanizadas da Venezuela das amostras de A. m. scutellata provenientes da África do Sul (Buco et al., 1987). Ainda por morfometria tradicional, estas abelhas puderam ser diferenciadas de seus híbridos com as abelhas de origem européia (Rinderer et al., 1990; 1993b).

No entanto, apesar de extremamente úteis, as técnicas de medidas de caracteres morfométricos até então existentes eram demoradas e dispendiosas. Entretanto, ultimamente, com o enorme avanço dos computadores e das técnicas computacionais, a evolução dos sistemas morfométricos para sistemas completamente automatizados foi significativa. Em 1995, Schröder et al. desenvolveram um sistema semi-automático de obtenção de medidas, classificação e identificação de espécies. Neste sistema chamado ABIS (Automated Bee Identification System), os pontos de junção de nervuras das asas anteriores tinham que ser manualmente marcados e o sistema, através de um complexo mecanismo de reconhecimento de padrões de imagens, identificava as nervuras e extraia as características de cada uma das asas, criando uma "impressão digital" de cada uma das asas. Para um reconhecimento e classificação com maior confiabilidade, o sistema precisava primeiro ser treinado com pelo menos 30 indivíduos por espécie. Uma vez feito esse treinamento, a identificação se torna extremamente rápida (Steinhage et al., 1997; Schröder et al., 2006), sendo que a automatização deste sistema foi publicada em 2001 (Steinhage et al., 2001), com dois grandes melhoramentos que facilitavam o uso do 
software e aumentavam a precisão das classificações. O primeiro deles foi a detecção automática dos pontos de junção de nervuras e marcação automática dos landmarks utilizados na análise. A segunda grande melhora no software foi a utilização de Análises Discriminantes Não Lineares de Kernel (KDA) (Roth \& Steinhage, 1999) ao invés da tradicional Análise Discriminante Linear (LDA). As KDA se utilizam de funções discriminantes não lineares que se dobram no espaço, permitindo uma melhor classificação dos grupos estudados e possibilitando uma taxa de acerto de até 99,8\% nas classificações dos indivíduos dentro de suas respectivas espécies, mesmo quando os grupos utilizados na análise apresentavam grandes similaridades, como no caso das abelhas do gênero Colletes, Andrena e Bombus.

O sistema automático também trabalha com base em um banco de dados que é montado a partir do treinamento do sistema com indivíduos previamente identificados. Entretanto, devido a sua completa automatização, o ABIS precisa seguir padrões rígidos de reconhecimento de formas. Assim sendo, em um primeiro momento ele identifica três células iniciais, a célula braquial e as duas células discoidais. Em um segundo passo, ele identifica as células cubitais e por fim a célula radial. Após identificar todas as células, ele reconhece as junções de nervura das células e as nomeia. A partir daí extrai várias características das células, veias e junções e forma seu banco de dados (Drauschke et al., 2007).

Uma outra técnica morfométrica que vem se mostrando muito promissora no estudo de variações de forma e da quantificação e reestruturação desta é a morfometria geométrica (Bookstein, 1991). Enquanto que em estudos de morfometria tradicional a variação da forma é estudada através da covariação de pares de medidas lineares, a morfometria geométrica é capaz de descrever e localizar mais claramente as regiões de mudanças na forma e, sobretudo, de reconstruir e restituir graficamente estas diferenças. Esta descrição pode ser feita através do estabelecimento de pontos anatômicos de referência em estruturas homólogas, ou ainda através da análise do contorno das estruturas, 
inovações que ampliaram as comparações entre as estruturas morfológicas não definidas por pontos de referência fixos.

Nas análises baseadas em pontos de referências, as coordenadas cartesianas destes pontos são as variáveis que capturam as informações sobre a geometria das estruturas estudadas. A vantagem do uso de coordenadas em relação a medidas lineares, é que estas incluem informação sobre as posições relativas, e deste modo permitem a reconstrução da forma estudada (Rohlf \& Marcus, 1993). Estas análises, baseadas em pontos de referência, incluem a eliminação do tamanho, padronizando todas as configurações para uma mesma medida geral de tamanho, assim como os efeitos de localização no espaço e da orientação da estrutura em questão. Retirando-se esses três efeitos, as diferenças observadas podem ser atribuídas somente à forma. Essa transformação é realizada através de uma medida geral multivariada de tamanho, e não por meio de uma medida única, como observado em índices de indicadores de tamanho. Além disso, pode-se detectar precisamente a localização das mudanças na forma, assim como o deslocamento de certos pontos em relação a outros, permitindo a visualização das diferenças na forma. As relações geométricas entre os pontos são deduzidas através do ajuste de uma função ao conjunto de pontos, e os parâmetros das funções ajustadas podem então ser usados como variáveis comparáveis com os métodos uni ou multivariados tradicionais (Monteiro \& Reis, 1999).

Um dos métodos mais empregados na morfométrica geométrica para avaliar e visualizar mudanças em configurações de pontos de referências é o de funções de deformação de placas finas (Bookstein, 1989). Estas funções, baseadas em um modelo físico de deformação de uma placa de metal de espessura desprezível e infinitamente grande, permitem descrever as diferenças entre duas conformações de pontos como uma deformação continua. Na pratica, é como se em uma placa de metal fossem marcados pontos de referência da forma a ser comparada. Esta placa é então deformada de modo que os seus pontos se encaixem sobre os pontos da forma a qual esta sendo comparada. A força feita para deformar a placa é uma quantificação das diferenças entre as formas, sendo que formas similares necessitarão de pouca deformação, e, portanto pouca energia envolvida, 
enquanto formas muito divergentes envolverão uma quantidade maior de energia para realizar a deformação (Monteiro \& Reis, 1999). Assim, podem-se descrever quantitativamente as diferenças entre duas formas através de grades de deformação como as descritas por Thompson (1917).

Os métodos de morfometria geométrica baseiam-se no chamado espaço da forma de Kendall. Este é um espaço multidimensional curvo no qual cada forma representa um ponto (Rohlf, 1996). No espaço da forma de Kendall as distâncias são distâncias geodésicas, geralmente medidas em radianos (distâncias de Procrustes). Como todos os métodos estatísticos habituais pressupõem um espaço linear (i.e. distâncias euclidianas), estes não podem ser aplicados às distâncias de Procrustes. Os pontos no espaço da forma podem, porém, ser projetados em um espaço linear, tangente ao espaço da forma, de modo que as distâncias lineares entre pontos correspondam a projeções das distâncias de Procrustes originais. Quando a variação da forma é pequena o suficiente, as projeções no espaço linear podem ser consideradas boas estimativas das distâncias de Procrustes (Monteiro \& Reis, 1999).

Como o espaço da forma é curvo, à medida que as formas se afastam do ponto de tangencia, as projeções tendem a diminuir no espaço linear. Portanto, sempre que possível, recomenda-se que o ponto de tangência entre dois espaços seja definido como sendo a média de todas as formas observadas, de modo que esta forma média esteja o mais eqüidistante de todas as formas estudadas e as variações sejam as menores possíveis (Rohlf, 1998). Esta forma média corresponde à media de todas as formas, tendo sido retiradas as diferenças de orientação, posição e tamanho, através de uma sobreposição por quadrados mínimos generalizada, ou sobreposição de Procrustes (Rohlf, 1999).

Nas distâncias de Procrustes a distância entre dois indivíduos é calculada com a soma dos quadrados das distâncias entre os pontos correspondentes de duas configurações. Do mesmo modo, o tamanho do centróide é a medida de tamanho usada para redimensionar, e corresponde à raiz da soma dos quadrados das distâncias entre cada ponto e seu centróide. Assim, quanto maior a configuração, mais longe estarão os pontos 
do centróide e maior o tamanho do centróide. Este tamanho constitui um único valor de tamanho e é o valor usado pra redimensionar as configurações para adequá-las ao espaço da forma. Portanto, a sobreposição de Procrustes é realizada da seguinte forma interativa: uma das formas é escolhida aleatoriamente, e todas as demais são rodadas, transladas e redimensionadas de modo que seus centróides se sobreponham, que seus tamanhos de centróides sejam iguais e que as distâncias de Procrustes entre elas sejam minimizadas. A média de todas estas configurações é calculada e o processo de rotação e sobreposição é repetido, sobrepondo todas as formas a esta média, e o mesmo processo é repetido até que não seja encontrada uma diminuição significativa nas distâncias de Procrustes entre as configurações. A configuração assim calculada é chamada de referência, configuração tangente ou configuração de consenso. As demais formas são então comparadas entre si através desta configuração de consenso (Rohlf \& Marcus, 1993).

Um método que vem se mostrando extremamente útil para avaliar a variação da forma existente em um conjunto de organismos é a Análise das Deformações Relativas (Rohlf, 1993), que se baseia no uso dos parâmetros das funções de deformação das placas finas, que transformam uma configuração de referência em cada configuração individual. A partir das coordenadas da configuração de referência com p pontos de referência estabelece-se uma matriz, denominada matriz de energia de deformação. Essa matriz é, em seguida, decomposta em duas matrizes, uma de auto valores e uma de autovetores.

Os autovetores que cobrem a extensão do espaço tangente definido pelos componentes não-afins da forma são chamados de Deformações Principais (Bookstein, 1991). A escala das deformações associadas a cada deformação principal está inversamente relacionada à magnitude do seu autovalor associado, e diretamente relacionada à quantidade de energia necessária para efetuar tal deformação. Autovalores elevados estão associados a deformações principais que descrevem deformações localizadas e em pequena escala, enquanto autovalores baixos estão associados a deformações em larga escala (Rohlf, 1993). Isto deriva do fato de que é necessário mais energia para deslocar dois pontos próximos numa placa fina do que para deslocar dois pontos muito afastados. Como as 
deformações principais são estabelecidas a partir de coordenadas de configuração de referência, estes simplesmente definem os principais eixos de deformações possíveis na configuração de referência.

Para descrever as deformações que transformam a configuração de referência nas configurações originais, as coordenadas de cada indivíduo são projetadas nas deformações principais. Os escores de cada indivíduo nas deformações principais descrevem o peso de cada deformação principal para transformar a configuração de referência na configuração destes indivíduos, e o conjunto destes escores forma a matriz de pesos W. A projeção das coordenadas de cada indivíduo nas deformações principais gera vetores chamados de Deformações Parciais, que são uma característica de cada individuo (Rohlf, 1993).

A Análise de Deformações Relativas consiste em realizar uma Análise de Componentes Principais sobre a matriz W. Os autovetores calculados são então chamados de Deformações Relativas, e estes descrevem os eixos ortogonais de maior variação da forma a partir das Deformações Parciais. Uma Análise de Componentes Principais realizada com as coordenadas dos pontos de referência de cada indivíduo após serem submetidos à sobreposição de Procrustes, resulta na mesma ordenação que uma Análise de Componentes Principais realizada com a matriz W, incluindo os Componentes Uniformes. A análise das Deformações Relativas também permite alterar o peso exponencial usado no cálculo da matriz W e das Deformações Parciais, denominado parâmetro alfa. O uso de um parâmetro $\alpha=0$ pesa de maneira igual todas as Deformações Parciais que descrevem as mudanças em todas as escalas espaciais (Rohlf, 1993). Valores de $\alpha>0$ (geralmente $=1$ ) dão mais ênfase a mudanças que ocorrem em larga escala espacial, ao passo que valores de $\alpha<0$ (geralmente $=-1$ ) dão mais peso a diferenças localizadas em pequena escala. De acordo com Rohlf \& Marcus (1993), estudos exploratórios devem sempre ser realizados com o padrão $\alpha$ estipulado como zero, uma vez que nada se sabe sobre as forças relacionadas com as deformações da estrutura em questão.

Embora largamente utilizada em estudos de variação de formas nos mais diversos organismos, como salmões (Hard et al., 2000), crânios de roedores (Dobigny et al., 2002), 
genitálias de machos de triatomídeos (Pires et al., 1998) e crânios de humanos (Frieß, 2003) entre outros, as técnicas de deformações relativas eram até pouco tempo praticamente ignoradas no estudo da variação da forma em abelhas. Somente uns poucos estudos bastante recentes foram realizados com o auxílio desta técnica. Smith et al (1997) estudaram o efeito da hibridização entre dois grupos no aparecimento de anormalidades na venação das asas de $A$. m. carnica, A. m. mellifera e seus híbridos Nigra. Estes efeitos, que são denominados de assimetria flutuante, também foram estudados em abelhas africanizadas, européias e seus híbridos, onde foi demonstrado que as abelhas africanizadas apresentam uma maior estabilidade durante seu desenvolvimento quando comparado com as abelhas européias e com os híbridos entre os dois grupos (Schneider, et al., 2003). Francoy e colaboradores (2006b) demonstraram ainda uma maior proximidade morfológica dos padrões de venação de asa das abelhas africanizadas com a subespécie africana $A . m$. scutellata, bem como as mudanças temporais destes padrões. Seu uso em abelhas sem ferrão teve início somente recentemente, onde tal metodologia provou ser bastante útil na separação e identificação de espécies do gênero Plebeia (Silva, 2006), bem como na demonstração de ausência de fluxo gênico entre duas populações de Plebeia remota (NunesSilva et al., submetido). Foram ainda encontradas diferenças entre subespécies de Melipona bicolor (Francoy et al., não publicado), entre populações de Nannotrigona testaceicoris e subestruturação populacional (Mendes, 2006) e diferenças entre o padrão de venação das asas anteriores em machos e fêmeas de Plebeia flavocincta (Silva, 2006).

Assim, a morfometria continua se mostrando cada vez mais promissora para a realização dos mais diversos tipos de trabalhos de identificação de espécimes ou grupos, ou mesmo comparações entre grupos, e, mesmo que não consiga demonstrar claramente níveis de hibridização entre raças ou subespécies em abelhas de uma população, como por exemplo o grau de africanização das populações de abelhas, se mostra muito útil na análise da variabilidade das mesmas quanto às características morfológicas. 


\section{2 - Aloenzimas.}

Os primeiros estudos de variabilidade bioquímica envolvendo abelhas africanizadas foram publicados no final dos anos 60 e início dos anos 70 (Mestriner, 1969; Mestriner \& Contel, 1972). Nestes trabalhos foram descritos a existência de sistemas polimórficos protéico (P3) e esterásico (Est), onde foram encontradas ainda diferenças nas freqüências gênicas entre as subespécies européias e abelhas africanizadas. Dentre os diversos sistemas polimórficos descritos (Martins et al., 1977; Bitondi \& Mestriner, 1983; Del Lama et al., 1985), a malato desidrogenase (MDH) (Contel et al., 1977) e a hexoquinase (Hk) (Del Lama et al., 1988) são os que mostram uma diferenciação substancial nas freqüências alélicas entre as subespécies pertencentes aos ramos C, A e M (Sheppard \& Smith, 2000). Os dados obtidos com estes marcadores para populações do Brasil, Uruguai e América Central indicam grande influência da subespécie africana $A . m$. scutellata nas populações, com baixa contribuição das subespécies européias, contribuição esta significativa, sendo $A$. m. mellifera a subespécie européia que mais contribui para as atuais populações, em detrimento das $A$. m. ligustica, que eram largamente utilizadas. Constatam ainda que as freqüências gênicas européias aumentam nas proximidades dos limites de distribuição geográfica dos enxames africanizados selvagens (Lobo et al., 1989; Del Lama et al., 1990; Lobo \& Krieger, 1992).

A maior limitação desta técnica é a baixa diversidade alélica encontrada em organismos haplo-diplóides, uma vez que mutações que apresentem mudanças na expressão funcional das formas expressas são fortemente selecionadas nos indivíduos haplóides (Pamilo et al., 1978; Pamilo \& Crozier, 1982).

\section{3 - Microssatélites.}

Ultimamente, os microssatélites têm se mostrado úteis para resolver praticamente todo problema que requer o uso de marcadores mendelianos (Queller et al., 1993). 
Aparentemente comuns em todos os eucariotos e também conhecidos por SSR (simple sequence repeats) e STR (simple tandem repeats), os microssatélites são uma classe de marcadores de DNA caracterizados por um número variável de repetições em tandem de seqüências que variam de 1 a 6 pares de bases (Estoup et al., 1995; Hughes \& Queller, 1993). Excetuando-se alguns loci que se encontram dentro de regiões expressas do genoma e geralmente estão associados a doenças (Sutherlands \& Richards, 1995; Watkins et al., 1995), a maior parte dos microssatélites conhecidos são porções não codificantes de DNA e, portanto, não estão sujeitas à ação da seleção natural. Assim sendo, possuem uma taxa de mutação relativamente alta, o que pode gerar um alto número de alelos, tornando essas seqüências bons marcadores para análises de paternidade. Mesmo em espécies onde a variabilidade enzimática é baixa, é provável que se encontre um alto número de microssatélites (Queller et al., 1993; Pamilo et al., 1997). Como são marcadores codominantes, e geralmente com uma alta variabilidade, microssatélites são bons para análises de genética de populações, estudos evolutivos de sistemas de acasalamento, identificação individual, fluxo gênico e sistemática de populações ou espécies próximas (Hughes \& Queller, 1993).

Em Apis mellifera, devido ao alto número de loci detectados (Estoup et al., 1993) e de sua grande diversidade alélica (Estoup et al., 1994), os microssatélites vêm sendo muito explorados para os mais diversos estudos, como por exemplo, na identificação genética de marcadores no uso de sêmen pelas rainhas (Haberl \& Tautz, 1998), na produção de zangões pelas operárias (Chaline et al., 2002), em estudos de biogeografia (Franck et al., 1998) e na separação das linhagens evolutivas dentro da espécie (Estoup et al., 1995). Em diversos loci foram encontrados alelos presentes somente nas populações Africanas ou então nas populações Européias, o que torna os microssatélites particularmente interessantes para estudos de introgressão e mistura gênica nas populações de abelhas Africanizadas (Estoup et al., 1995). Em um estudo realizado na península de Yucatan no México, foram detectados em torno de $65 \%$ de alelos tipicamente africanos, apenas 12 anos 
após a chegada das abelhas Africanizadas naquele território, que antes da chegada era considerado como tendo uma das maiores concentrações de colméias de A. mellifera de origem Européia do mundo (Clarke et al., 2002), o que evidencia a rápida africanização das abelhas na região e o domínio das características morfológicas e comportamentais das abelhas $A$. m. scutellata.

\section{4 - DNA mitocondrial}

Salvo algumas exceções (Warrior \& Gall, 1985), o DNA mitocondrial de animais é uma molécula circular que é herdada maternalmente e sem recombinações (Avise et al., 1987). Sua taxa de mutação é compatível com a dos genes nucleares, apresentando regiões mais ou menos variáveis, o que o nos permite a escolha de regiões mais adequadas para os diversos trabalhos e níveis taxonômicos a serem estudados (Arias et al., 2006).

Em A. mellifera L., os sítios de restrição foram inicialmente descritos por Moritz et al. (1986) tendo muitos outros estudos sido realizados (Hall \& Muralidharan, 1989; Smith e Brow, 1990; Sheppard et al., 1991a; b; Segura, 2000). A descrição inicial do mapa genético do DNA mitocondrial para esta espécie foi feita por Cornuet \& Garnery (1991), tendo sido completada por Crozier \& Crozier em 1993.

Em sua maioria, os estudos de DNA mitocondrial realizados em áreas onde as abelhas africanizadas já estão estabelecidas há algum tempo, como Brasil, Colômbia e Venezuela, indicam uma quase que completa predominância de colônias de origem materna Africana (Rotta, 1999; Diniz et al., 2003; Collet et al., 2006). Mesmo regiões colonizadas há menos tempo, como o México, apresentam uma predominância de DNA mitocondrial de origem africana em suas colônias selvagens (Clarke et al., 2001), reforçando ainda mais a idéia do reduzido número de colônias européias estabelecidas como enxames selvagens. No Panamá, Boheram \& Roubik (1987) mencionam ainda o fato de nunca haverem encontrado enxames naturais antes da chegada das abelhas africanizadas naquele território. 
Assim, os marcadores de DNA mitocondrial se mostram muito úteis para estudos de fluxo gênico materno e no caso de abelhas, como marcador para dispersão dos enxames. 
eve

Objetivos 
Existem atualmente diversas metodologias que normalmente são empregadas no estudo da estruturação genética das populações de abelhas africanizadas e também na diferenciação de subespécies de abelhas Apis mellifera. Entretanto, normalmente estas ferramentas são utilizadas separadamente e uma integração destas metodologias pode nos fornecer respostas mais concretas. Desta maneira, este trabalho teve por objetivos:

- Avaliar a variabilidade morfológica em populações Neotropicais de Apis mellifera coletadas no Brasil e no Panamá;

- Quantificar a porcentagem de DNA mitocondrial de origem européia e africana encontrada nas atuais populações de abelhas africanizadas;

- Testar o uso de morfometria geométrica e do software ABIS na identificação de populações, subespécies e outros grupos de abelhas Apis mellifera;

- Estabelecer protocolos de análise para estas duas novas metodologias, que até o presente momento são inéditas quando usadas na identificação de Apis mellifera;

- Avaliar as mudanças temporais ocorridas nas abelhas africanizadas desde o início do processo de africanização até o presente mediante análises morfométricas e de DNA mitocondrial de abelhas coletadas no Panamá e em Ribeirão Preto - SP. 
\&

Materiais e Métodos 


\section{1 - Material Biológico}

Amostras de operárias foram coletadas a partir de colônias de abelhas africanizadas provenientes de apiários comerciais e experimentais de todas as regiões do país em um total de 394 colônias (Tabela 1). Amostras de 25 colméias foram coletadas na cidade de Ribeirão Preto - SP durante o período de 1965 a 1968 (Gonçalves, 1970). Tais amostras foram armazenadas e mantidas secas até o momento das atuais análises. Adicionalmente foram coletadas em 2006 amostras de nove colônias italianas provenientes da ilha de Fernando de Noronha - PE, onde foram introduzidas no ano de 1984 rainhas instrumentalmente inseminadas que eram filhas de rainhas do tipo comercial Italiano (Italian Comercial Type) importadas da Califórnia e da Geórgia nos EUA (Malagodi et al., 1986). Foram também amostradas 10 colônias de abelhas africanizadas na região central do Panamá, provenientes do Apiário Experimental do Instituto Smithsonian de Pesquisas Tropicais. Estas últimas amostras, que foram gentilmente coletadas e enviadas por correio pelo Prof. Dr. David Roubik, consistiam de asas anteriores e pernas de operárias. O Dr. Roubik ainda nos forneceu amostras de operárias dos 10 primeiros enxames naturais coletados no ano de 1982, ano em que os primeiros enxames africanizados foram relatados naquele país (Roubik, 1982), sendo que estas últimas estavam armazenadas em álcool 70\%. Amostras de 10 enxames naturais de Apis mellifera scutellata, provenientes da região da Pretória - África do Sul foram também coletadas e armazenadas em álcool 70\% pelo Prof. Dr. Connal Eardley, que gentilmente nos enviou esses exemplares. 
Tabela 1: Localidade com populações de abelhas africanizadas amostradas no Brasil. Os dados de latitude (LS), longitude (LW) e altitude foram conseguidos com o auxílio do software Google Earth (www.earth.google.com). Os dados de temperatura média anual foram conseguidos junto ao site do Instituto Nacional de Pesquisas Espaciais (www.inpe.br). LS = Latitude Sul; LW = Longitude Oeste. Os dados de temperatura média anual (T) estão em graus Celsius e a altitude em metros.

\begin{tabular}{|c|c|c|c|c|c|c|}
\hline Localidade & Código & LS & LW & $\mathrm{T}^{\circ}$ anual média & Altitude & N colônias \\
\hline Curitiba-PR & $\mathrm{CB}$ & $25^{\circ} 25^{\prime}$ & $49^{\circ} 17^{\prime}$ & \begin{tabular}{|l|}
16,9 \\
\end{tabular} & 915 & 20 \\
\hline Porto Alegre - RS & PA & $30^{\circ} 02^{\prime}$ & $51^{\circ} 13^{\prime}$ & 19,4 & 18 & 15 \\
\hline Florianópolis - SC & FL & $27^{\circ} 35^{\prime}$ & $48^{\circ} 32^{\prime}$ & 20,4 & 15 & 19 \\
\hline Aquidauana-MS & $\mathrm{AQ}$ & $20^{\circ} 28^{\prime}$ & $55^{\circ} 47^{\prime}$ & 24,5 & 149 & 19 \\
\hline Alegrete-RS & $\mathrm{AI}$ & $29^{\circ} 47^{\prime}$ & $55^{\circ} 47^{\prime}$ & 18,6 & 95 & 14 \\
\hline Santa Maria-RS & $\mathrm{SM}$ & $29^{\circ} 41^{\prime}$ & $53^{\circ} 49^{\prime}$ & 19,2 & 132 & 20 \\
\hline Maringá-PR & MA & $23^{\circ} 24^{\prime}$ & $51^{\circ} 55^{\prime}$ & 20,3 & 563 & 10 \\
\hline Picos-PI & PI & $7^{\circ} 05^{\prime}$ & $41^{\circ} 46^{\prime}$ & 30 & 254 & 25 \\
\hline Crato - CE & $\mathrm{CT}$ & $7^{\circ} 14^{\prime}$ & $39^{\circ} 25^{\prime}$ & 27 & 483 & 22 \\
\hline Catolé do Rocha-PB & $\mathrm{CR}$ & $6^{\circ} 20^{\prime}$ & $37^{\circ} 45^{\prime}$ & 27 & 280 & 3 \\
\hline Baraúna-RN & $\mathrm{BA}$ & $5^{\circ} 05^{\prime}$ & $37^{\circ} 36$ & 27,5 & 97 & 6 \\
\hline Serra do Mel-RN & $\mathrm{SE}$ & $5^{\circ} 10^{\prime}$ & $37^{\circ} 02^{\prime}$ & 27,5 & 217 & 8 \\
\hline Severiano Melo-RN & SEM & $5^{\circ} 46^{\prime}$ & $37^{\circ} 57^{\prime}$ & 27,5 & 148 & 5 \\
\hline Mossoró-RN & MO & $5^{\circ} 11^{\prime}$ & $37^{\circ} 20$ & 27,5 & 15 & 5 \\
\hline Salvador - BA & AS & $12^{\circ} 58^{\prime}$ & $38^{\circ} 30^{\prime}$ & 25,3 & 10 & 13 \\
\hline São João da Boa Vista - SP & SJ & $21^{\circ} 59^{\prime}$ & $46^{\circ} 47^{\prime}$ & 22,3 & 792 & 12 \\
\hline Araripina-PE & $\mathrm{AR}$ & $7^{\circ} 33^{\prime}$ & $40^{\circ} 34^{\prime}$ & 24 & 648 & 20 \\
\hline Fortaleza-CE & $\mathrm{FO}$ & $3^{\circ} 46^{\prime}$ & $38^{\circ} 35^{\prime}$ & 26,5 & 20 & 40 \\
\hline Tucano-BA & TU & $10^{\circ} 58^{\prime}$ & $38^{\circ} 47^{\prime}$ & 26 & 205 & 20 \\
\hline Belém-PA & $\mathrm{BE}$ & $1^{\circ} 26^{\prime}$ & $48^{\circ} 29^{\prime}$ & 26,1 & 5 & 20 \\
\hline Săo Luis - MA & SL & $2^{\circ} 31^{\prime}$ & $44^{\circ} 18$ & 26 & 12 & 20 \\
\hline Rio de Janeiro - RJ & $\mathrm{RJ}$ & $22^{\circ} 54^{\prime}$ & $43^{\circ} 12^{\prime}$ & 23,9 & 8 & 20 \\
\hline Aracaju-SE & $\mathrm{AJ}$ & $10^{\circ} 54^{\prime}$ & $37^{\circ} 03^{\prime}$ & 26 & 15 & 20 \\
\hline Ribeirão Preto - $2002-\mathrm{SP}$ & RP-2002 & $21^{\circ} 10^{\prime}$ & $47^{\circ} 51^{\prime}$ & 22,5 & 581 & 18 \\
\hline Ribeirão Preto 1968 - SP & RP-1968 & $21^{\circ} 10^{\prime}$ & $47^{\circ} 51^{\prime}$ & - & 581 & 25 \\
\hline
\end{tabular}

Por ocasião de duas visitas que fizemos ao Institut für Bienenkunde em Oberursel Alemanha, o Prof. Dr. Stefan Fuchs gentilmente nos cedeu amostras digitalizadas de imagens de asas de abelhas das subespécies scutellata, mellifera, ligustica e carnica. Tais imagens foram utilizadas nas análises morfométricas como base de comparação para as outras populações e também como grupos externos na verificação da influência de cada subespécie no perfil morfométrico das populações de abelhas africanizadas amostradas neste trabalho. 
O material biológico total consistiu de 32 grupos, onde constam as 25 localidades da tabela 1, as quatro subespécies cedidas pelo Dr. Fuchs, a amostra de Fernando de Noronha - PE e as duas amostras do Panamá.

\section{2 - Montagem das asas e captura das imagens.}

As asas anteriores direitas das operárias foram retiradas com o auxílio de pinças e foram posicionadas entre lâminas de microscopia, as quais eram separadas por pequenas quantidades de massa de modelar em suas extremidades. As análises envolvendo as populações africanizadas brasileiras tiveram seus dados coletados a partir de amostras de cinco operarias por colônia. Como um dos objetivos deste trabalho é o de estabelecer protocolos de análise para a metodologia de morfometria geométrica, nos estudos envolvendo as mudanças temporais na morfologia das abelhas do Panamá, foram utilizadas amostras de 10 operárias por colônia das subespécies puras, visando estabelecer o melhor número a ser coletado para a identificação dos grupos.

Nas análises envolvendo os dados de morfometria geométrica foram utilizadas as amostras de asas que nos foram cedidas pelo Dr. Fuchs, que são mais representativas das subespécies. Entretanto, para os estudos de morfometria tradicional, foram utilizadas as amostras de A. m. scutellata que nos foram cedidas pelo Dr. Eardley, que foram coletadas na mesma região de origem de onde vieram os enxames importados em 1956 e, portanto, menos sujeitos a variações ambientais relativas ao tamanho das asas. Cada uma destas asas teve sua imagem capturada com o auxílio de uma câmera digital acoplada a um estereomicroscópio. $\mathrm{O}$ restante do corpo da abelha era preservado a $-20^{\circ} \mathrm{C}$ para a realização dos estudos moleculares.

\section{3 - Morfometria tradicional.}

Foram medidos o comprimento e largura das asas anteriores bem como o comprimento da célula radial. As medidas foram realizadas com o auxílio do software SigmaScan 5.0 (SPSS Inc.). 


\section{4-Morfometria geométrica.}

Todos os softwares necessários para a realização das análises de morfometria geométrica estão disponíveis na internet (http://life.bio.sunysb.edu/morph/) e são de uso livre. Primeiramente, com o auxílio do software tpsUtil versão 1.33 (Rohlf, 2004) foi construído um arquivo para possibilitar a análise das imagens previamente capturadas. Posteriormente 19 marcos anatômicos homólogos foram manualmente marcados nas intersecções das veias das asas anteriores (Figura 4) com o auxílio do software tpsDig, versão 2.04 (Rohlf, 2005a). As imagens foram então alinhadas de acordo com a metodologia de morfometria geométrica (distância de Procrustes) e tiveram suas medidas de deformações relativas calculadas no software tpsRelw versão 1.42 (Rohlf, 2005b).

A partir dos 19 marcos anatômicos foram geradas 34 medidas de deformações relativas $(\mathrm{k}=2 \mathrm{n}-4)$ sendo que $\mathrm{k}$ é igual ao número total de deformações relativas e $\mathrm{n}$ é igual ao número de marcos anatômicos.

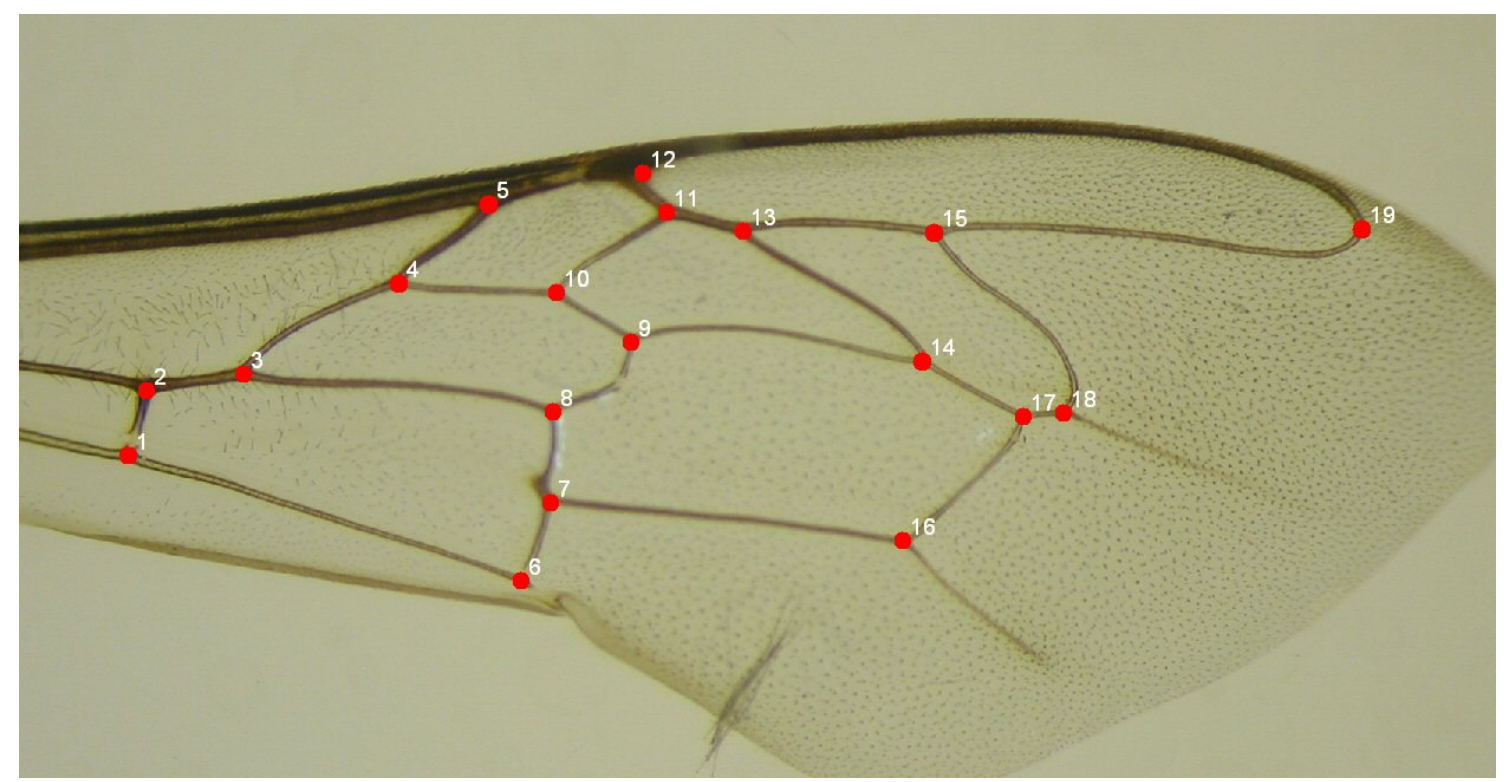

Figura 4: Asa anterior direita de uma abelha africanizada com os 19 marcos anatômicos (vermelho) marcados nas intersecções das veias alares.

Os dados referentes ao posicionamento relativo de cada marco anatômico foram analisados no software MORPHEUS (Slice, 1998) e tiveram sua forma reconstruída, o que 
possibilitou uma visualização do deslocamento de cada um dos pontos nas configurações médias das populações.

O principal objetivo desta análise é o de comparar morfologicamente as populações Neotropicais de abelhas $A$. mellifera, incluindo também as subespécies ancestrais a fim de se delimitar a influência das mesmas no atual status de hibridização apresentado. As amostras foram analisadas de duas maneiras diferentes; uma delas levando-se em consideração as medidas obtidas para cada indivíduo e na outra, foram analisadas as formas médias dos indivíduos pertencentes à mesma colônia, sendo então a colônia tratada como unidade evolutiva.

\section{5 - Sistema morfométrico J - ABIS (Automatic Bee Identification System).}

O sistema morfométrico ABIS é um software que foi desenvolvido primariamente para a identificação de espécies de abelhas a partir dos padrões de nervação das asas anteriores. Como foi criado para um fim muito específico, o ABIS não permite aos usuários o acesso aos dados brutos, mostrando somente o procedimento de análise e o resultado final. Primeiramente ele faz uma análise totalmente automatizada das imagens das asas anteriores das abelhas. O resultado desta análise é a completa rede de venação das asas (Figura 5). De acordo com Schröder et al. (2006) as medidas estruturais da rede de venação (distâncias, áreas de células, curvaturas das nervuras e etc.) são utilizada na obtenção das equações de discriminação e classificação dos grupos. Uma vez feita a extração das medidas, o ABIS tem duas opções de análises estatísticas; uma baseada nas clássicas Análises Discriminantes Lineares de Fisher (LDA) e alternativamente Análises Discriminantes Não-Lineares de Kernel (KDA) (Roth \& Steinhage, 1999). Entretanto, estes métodos de classificação pertencem à classe dos métodos de classificação supervisionados, ou seja, o método de classificação precisa ser treinado a priori com aproximadamente 20 indivíduos por grupo (espécie, raça, população) previamente classificados para serem utilizados no ABIS. Uma vez feita a classificação, o ABIS mostra os resultados em forma de tabelas de classificação e gráficos de dispersão. 


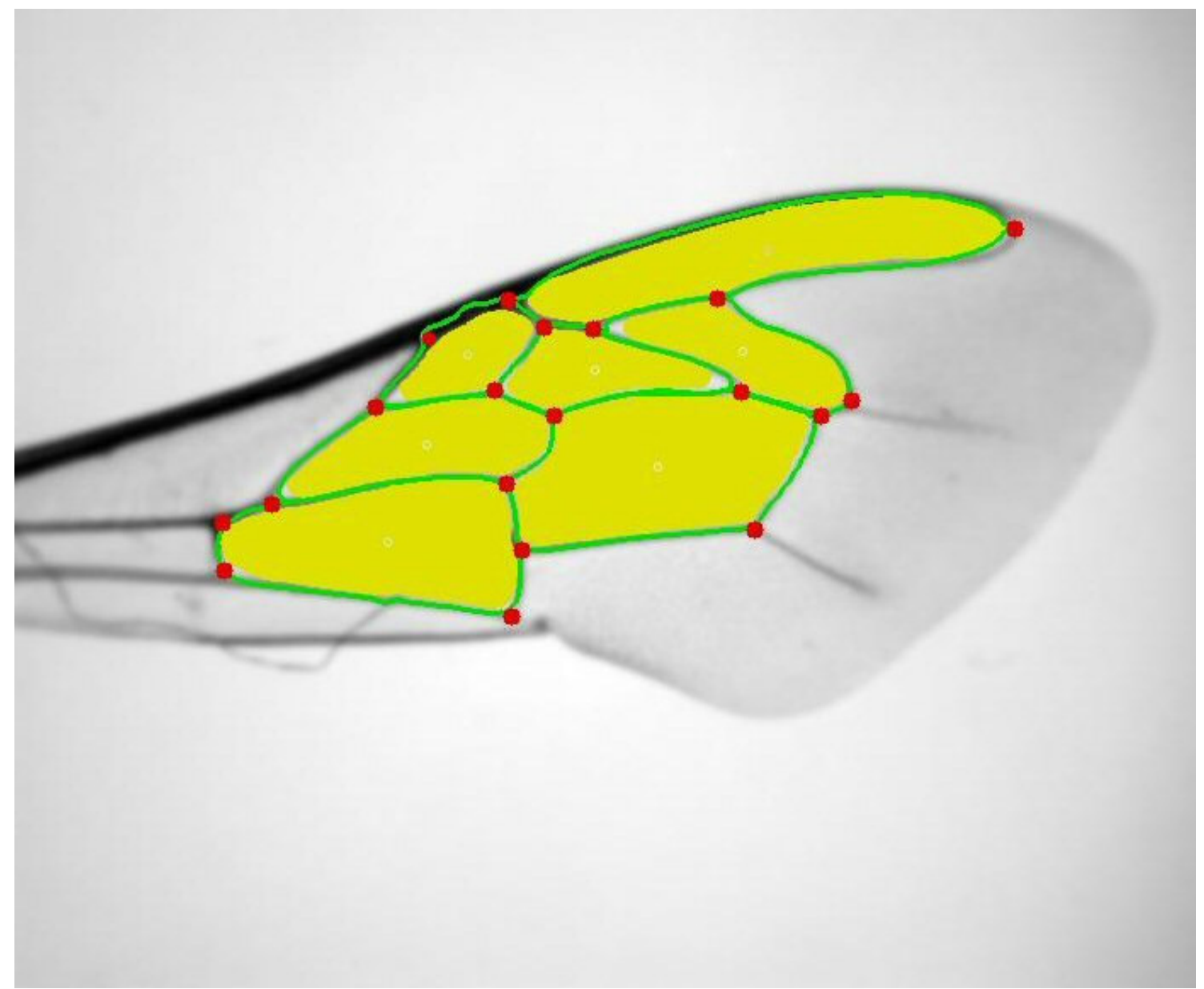

Figura 5: Asa anterior direita de uma abelha africanizada com 19 marcos anatômicos (vermelho) marcados automaticamente pelo software ABIS. As linhas em verde indicam a rede de nervuras extraídas pelo software e as partes em amarelo indicam o restante das características calculadas.

Para as análises no ABIS, os mesmos 19 marcos anatômicos utilizados na morfometria geométrica foram escolhidos. Após o treinamento com 30 indivíduos por grupo, todas as amostras foram analisadas pelo sistema e as taxas de classificação foram calculadas.

\section{6 - Extração do DNA}

Para a realização dos estudos moleculares foi realizada a extração do DNA de um indivíduo (operária) por colônia. A extração do DNA para estudo dos microssatélites e do DNA mitocondrial foi baseada na metodologia proposta por Innis et al. (1990), com algumas modificações. O DNA das amostras recentes de abelhas africanizadas foi extraído do par de antenas de cada abelha, ficando o restante da abelha preservado para estudos 
posteriores. Para extração foi utilizado Tampão Tris- $\mathrm{HCl}$ 0,005M, pH 8,5 ( $\mathrm{KCl}$ 0,01M; $\mathrm{MgCl}_{2}$ 0,0025 M; NP-40 1\%; sacarose $\left.13,8 \%\right)$ e proteinase $\mathrm{K}(0,02 \%)$. As antenas de cada indivíduo foram colocadas em tubos eppendorf individuais contendo $48 \mu 1$ de tampão e $2 \mu 1$ de proteinase $\mathrm{K}$, sendo aquecidas a $62^{\circ} \mathrm{C}$ por 2 horas e trinta minutos. Em seguida a proteinase $\mathrm{K}$ era inativada por aquecimento a $92^{\circ} \mathrm{C}$ por 10 minutos. A mesma metodologia foi seguida para as amostras armazenadas em álcool, porém aquecidas a apenas $37^{\circ} \mathrm{C}$ por 12 horas. Já para as amostras panamenhas, quando da existência de pernas, estas eram utilizadas em substituição as antenas. Quando da ausência de pernas nas amostras, as próprias asas foram utilizadas como fonte de extração de DNA. Estas amostras seguiam o procedimento normal de extração. A extração das amostras secas foi realizada diretamente da musculatura das asas mediante dissecção com o auxílio de pinças. Devido à pequena quantidade de DNA existente nestes exemplares, a reação era aquecida a $62^{\circ} \mathrm{C}$ por duas horas e trinta minutos e na seqüência era mantida a $37^{\circ} \mathrm{C}$ por 12 horas. $\mathrm{O}$ DNA assim extraído foi mantido a $-20^{\circ} \mathrm{C}$.

\section{7 - Amplificação do DNA Mitocondrial.}

Todas as amostras de operárias das 394 colônias africanizadas tiveram seu DNA mitocondrial identificado quanto a sua origem, seja ela africana ou européia, juntamente com todas as amostras provenientes do Panamá e outras nove amostras das colônias de Ribeirão Preto da década de 60. Das 25 colônias amostradas em 1968, nove já haviam tido seu DNA mitocondrial identificado quanto à origem materna (Arias et al., não publicado). Já para as sete colônias restantes, não foi possível a amplificação do DNA devido a problemas com a extração do mesmo. Todas as colônias de Fernando de Noronha - PE existentes em 1999 já haviam tido a origem de seu DNA mitocondrial identificada por Rotta (1999). Como não houve nenhuma introdução de abelhas novas na ilha nos últimos anos, estas amostras não foram analisadas quanto à origem de seu DNA mitocondrial, uma vez que todos haviam sido identificados como sendo de origem européia. 
Para tanto, uma abelha por colméia teve seu loco do Cit B (FWD 5'TAT GTA CTA CCA TGA GGA CAA ATA TC3' REV 5'ATT ACA CCT CCT AAT TTA TTA GGA AT3') (Hall \& Smith, 1991) amplificado de acordo com a seguinte reação:

Mistura de reação:

$2 \mu 1$ da solução de DNA

$1 \mu 1$ de primer FWD $(10$ pmoles $/ \mu \mathrm{l})$

$1 \mu 1$ de primer REV $(10$ pmoles $/ \mu 1)$

$10 \mu 1$ de solução Eppendorf® MasterMix 2.5x

$\mathrm{H} 2 \mathrm{O}$ para completar $25 \mu 1$

O lócus do Cit B foi amplificado em um termociclador GeneAmp ${ }^{\circledR}$ PCR System 9700, seguindo o programa abaixo (Figura 6):

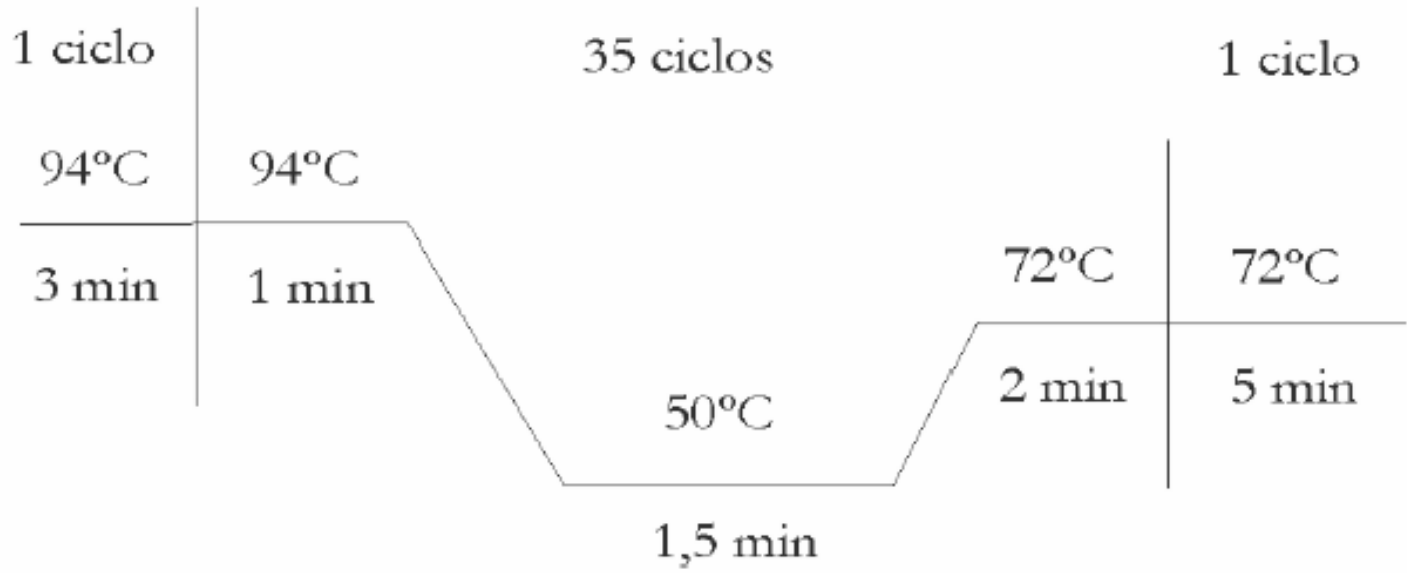

Figura 6: Ciclos de Reação para amplificação dos genes mitocondriais.

A escolha deste loco se deu devido à existência de um sítio de restrição para a enzima Bgl II que diferencia os mitótipos das subespécies européias dos mitótipos das subespécies africanas (Hall \& Smith, 1991).

Quando da existência do sítio de restrição na amostra, estas eram analisadas quanto a sua origem dentro das subespécies européias. Para tanto, foi amplificada a região 
intergênica COI-COII, a qual apresenta um sítio de restrição para a enzima $X b a I$ nas abelhas no leste europeu, sítio este ausente nas subespécies do oeste europeu.

Para esta amplificação, foram utilizados os primers utilizados por Rotta (1999) (FWD: 5' TCT ATA CCA CGA CGT TAT TC 3' REV: 5' GAT CAA TAT CAT TGA TGA CC 3') e foram utilizadas a mesma mistura de reação de PCR e o mesmo programa (Figura 6) para a amplificação do DNA.

\section{8 - Análise do DNA Mitocondrial}

Primeiramente, $5 \mu \mathrm{l}$ do material amplificado de cada amostra analisado em um gel de poliacrilamida $8 \%$ para a verificação da amplificação do material e este era corado com nitrato de prata para visualização dos fragmentos amplificados (Sanguinetti et al., 1994). Quando positiva a resposta, essa amostra era submetida a uma reação com a enzima de restrição $B g l$ II de acordo com a seguinte mistura:

Mistura da reação:

$20 \mu 1$ de material amplificado por PCR

$1 \mu 1$ de enzima $B g l \mathrm{II}$

2,5 $\mu 1$ de tampão da enzima

$1,5 \mu 1$ de água.

Esta reação era mantida em banho Maria à $37^{\circ} \mathrm{C}$ por 2 horas. Após este período, as amostras eram analisadas em gel de poliacrilamida $8 \%$ para a verificação da presença ou ausência do sítio de restrição.

Quando da presença do sítio de restrição, o mesmo procedimento era realizado para as amostras, só que com o produto de PCR para o locus COI-COII e com a enzima de restrição $X b a \mathrm{I}$. 


\section{9 - Análises estatísticas}

Os dados de morfometria tradicional tiveram sua média e desvio padrão calculados. Foi calculada ainda a correlação entre os dados morfométricos e dados de latitude, altitude e temperatura média anual de cada uma das localidades amostradas. Os dados climáticos foram conseguidos junto ao site do Instituto Nacional de Pesquisas Espaciais (www.inpe.br).

Os resultados do ABIS são apresentados em forma de tabelas de classificação e também gráficos de dispersão de pontos. Entretanto, o ABIS, por ser totalmente automático, não permite acesso aos dados brutos extraídos das asas, o que impossibilita uma análise mais detalhada, como identificação dos parâmetros que mais diferenciam os grupos e a significância deles.

Os dados de morfometria geométrica foram processados mediante análises discriminantes lineares no software STATISTICA 6.0 (Statsoft, 2001) e SPSS 15.0 (SPSS Inc.) e as distâncias lineares quadradas de Mahalanobis entre os grupos foram calculadas. Árvores de proximidades morfológicas foram construídas com o auxílio do software MEGA versão 2.1 (Kumar et al., 2001). 
Dld

Resultados 


\section{1 - Populações brasileiras.}

\subsection{1 - Morfometria tradicional.}

Foram calculados a média e o desvio padrão das medidas de comprimento da asa anterior, largura da asa anterior e comprimento da célula radial para cada uma das localidades brasileiras amostradas (tabela 2). Os dados mostram uma diminuição gradativa destas medidas em direção ao norte do país.

Tabela 2: Média e desvio padrão das medidas de morfometria tradicional para cada uma das localidades amostradas. $\mathrm{CA}=$ Comprimento da asa anterior; $\mathrm{LA}=$ Largura da asa anterior; $\mathrm{CR}=$ Comprimento da célula radial.

\begin{tabular}{|c|c|c|c|c|c|}
\hline Localidade & código & CA & LA & CR & N \\
\hline Curitiba - PR & CB & $0.832 \pm 0,018$ & $0.292 \pm 0,008$ & $0.328 \pm 0,009$ & 99 \\
\hline Porto Alegre - RS & PA & $0.833 \pm 0,018$ & $0.306 \pm 0,010$ & $0.316 \pm 0,010$ & 74 \\
\hline Florianópolis - SC & FL & $0.833 \pm 0,020$ & $0.294 \pm 0,007$ & $0.331 \pm 0,009$ & 93 \\
\hline Aquidauana - MS & AQ & $0.812 \pm 0,021$ & $0.287 \pm 0,007$ & $0.325 \pm 0.008$ & 96 \\
\hline Alegrete - RS & AL & $0.831 \pm 0,017$ & $0.295 \pm 0,008$ & $0.331 \pm 0,009$ & 68 \\
\hline Santa Maria - RS & SM & $0.837 \pm 0,021$ & $0.293 \pm 0,009$ & $0.330 \pm 0,009$ & 97 \\
\hline Maringá - PR & MA & $0.839 \pm 0,018$ & $0.293 \pm 0,008$ & $0.329 \pm 0,009$ & 46 \\
\hline Picos - PI & PI & $0.810 \pm 0,017$ & $0.292 \pm 0,007$ & $0.325 \pm 0,009$ & 105 \\
\hline Crato - CE & CT & $0.810 \pm 0,021$ & $0.287 \pm 0,011$ & $0.318 \pm 0,012$ & 74 \\
\hline Catolé do Rocha - PB & CR & $0.796 \pm 0,016$ & $0.292 \pm 0,011$ & $0.314 \pm 0,008$ & 15 \\
\hline Baraúna - RN & BA & $0.806 \pm 0,015$ & $0.283 \pm 0,006$ & $0.298 \pm 0,007$ & 30 \\
\hline Serra do Mel - RN & SE & $0.801 \pm 0,022$ & $0.280 \pm 0,009$ & $0.295 \pm 0,009$ & 33 \\
\hline Severiano Melo - RN & SEM & $0.808 \pm 0,011$ & $0.288 \pm 0,007$ & $0.300 \pm 0,006$ & 17 \\
\hline Mossoró - RN & MO & $0.808 \pm 0,013$ & $0.282 \pm 0,006$ & $0.299 \pm 0,004$ & 25 \\
\hline Salvador - BA & SA & $0.814 \pm 0,018$ & $0.287 \pm 0,007$ & $0.297 \pm 0,007$ & 66 \\
\hline São João da Boa Vista - SP & SJ & $0.836 \pm 0,016$ & $0.291 \pm 0,006$ & $0.306 \pm 0,007$ & 60 \\
\hline Araripina - PE & AR & $0.819 \pm 0,016$ & $0.285 \pm 0,006$ & $0.299 \pm 0,007$ & 97 \\
\hline Fortaleza - CE & FO & $0.808 \pm 0,017$ & $0.281 \pm 0,006$ & $0.296 \pm 0,008$ & 185 \\
\hline Tucano - BA & TU & $0.811 \pm 0,018$ & $0.282 \pm 0,007$ & $0.296 \pm 0,008$ & 100 \\
\hline Belém - PA & BE & $0.824 \pm 0,013$ & $0.288 \pm 0,007$ & $0.301 \pm 0,006$ & 99 \\
\hline São Luis - MA & SL & $0.804 \pm 0,016$ & $0.280 \pm 0,005$ & $0.297 \pm 0,007$ & 100 \\
\hline Rio de Janeiro - RJ & RJ & $0.841 \pm 0,017$ & $0.288 \pm 0,006$ & $0.305 \pm 0,007$ & 100 \\
\hline Aracaju - SE & AJ & $0.821 \pm 0,020$ & $0.282 \pm 0,007$ & $0.300 \pm 0,008$ & 99 \\
\hline Ribeirão Preto - SP & RP-2002 & $0.822 \pm 0,014$ & $0.289 \pm 0,008$ & $0.296 \pm 0,007$ & 92 \\
\hline & & & &
\end{tabular}

Foi encontrada uma correlação positiva entre comprimento da asa anterior e latitude sul $(\mathrm{r}=0,821)$, largura da asa anterior e latitude sul $(\mathrm{r}=0,740)$ e comprimento da asa anterior e latitude sul $(r=0,675)$ (Figura 7). Foi também encontrada correlação negativa entre comprimento da asa anterior e temperatura média anual $(r=-0,810)$, largura da asa anterior e temperatura média anual $(\mathrm{r}=-0,654)$ e comprimento da célula radial e temperatura média anual $(\mathrm{r}=0,600)$ (Figura 8), sendo que todas foram 
estatisticamente significantes $(\mathrm{P}<0,05)$. Já as correlações entre as medidas realizadas e a altitude da localidade não foram estatisticamente significantes. A correlação altitude $\mathrm{X}$ comprimento da asa anterior $(r=0,232)$ apresentou um $p=0,275$, altitude $X$ largura da asa anterior $(\mathrm{r}=0,146)$ apresentou $\mathrm{p}=0,490$ e altitude $\mathrm{X}$ comprimento da célula radial $(\mathrm{r}=$ 0,194) apresentou um $\mathrm{p}=0,361$ (Figura 9).

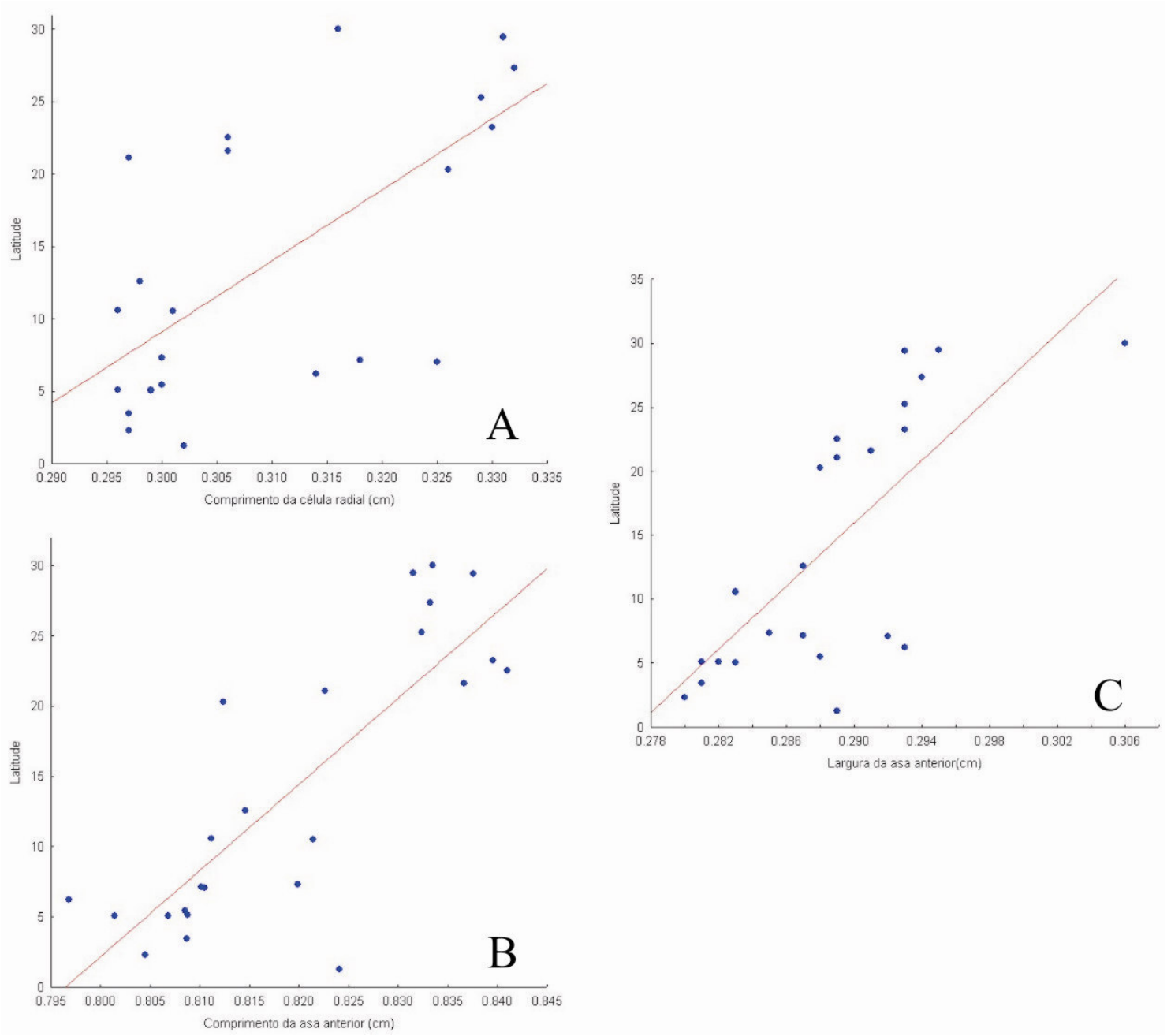

Figura 7: Regressões lineares entre as medidas de comprimento da célula radial (A) e de comprimento (B) e largura (C) da asa anterior em relação à latitude sul das localidades. 


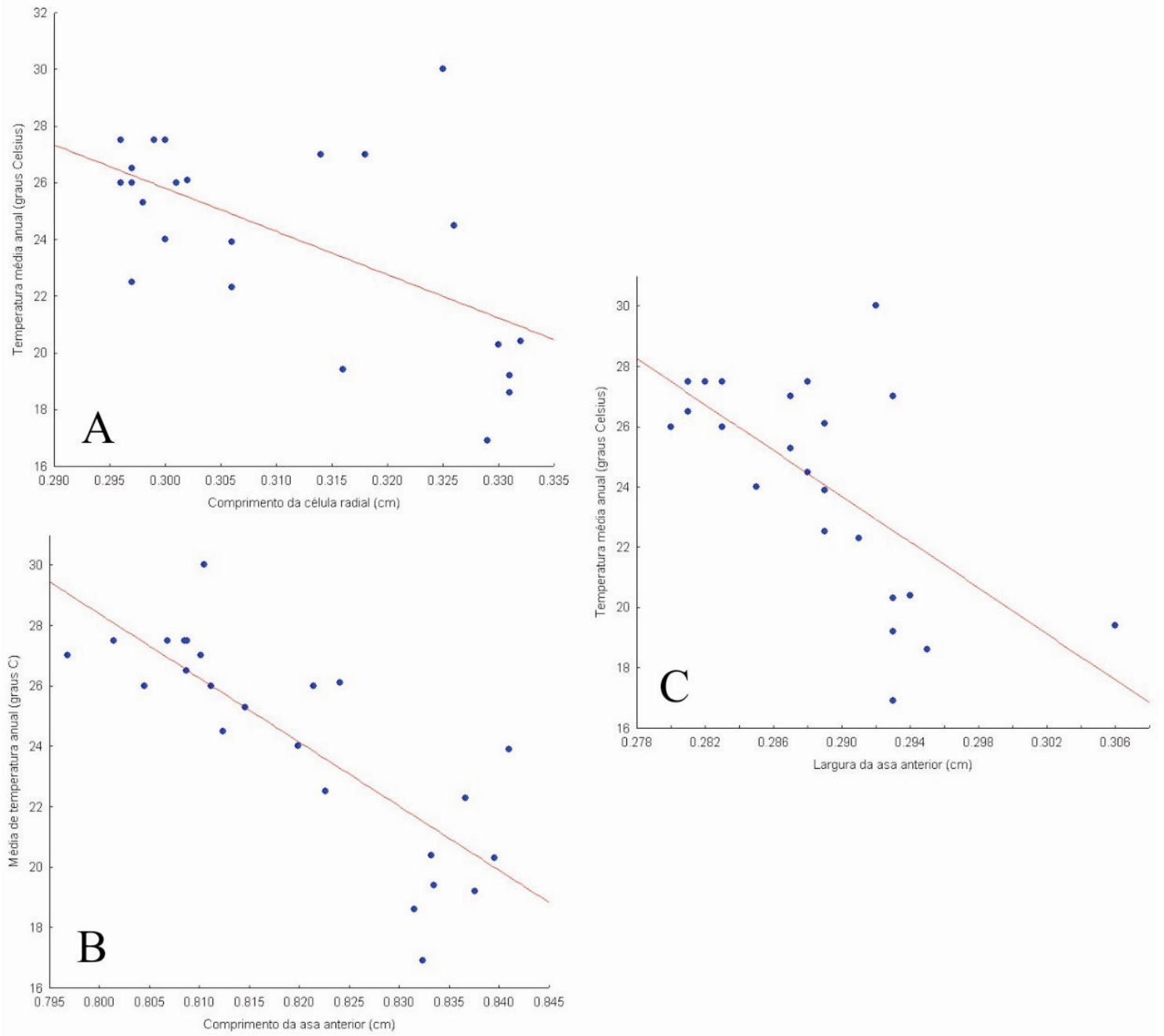

Figura 8: Regressões lineares entre as medidas de comprimento da célula radial (A) e de comprimento (B) e largura (C) da asa anterior em relação à média de temperatura anual das localidades. 


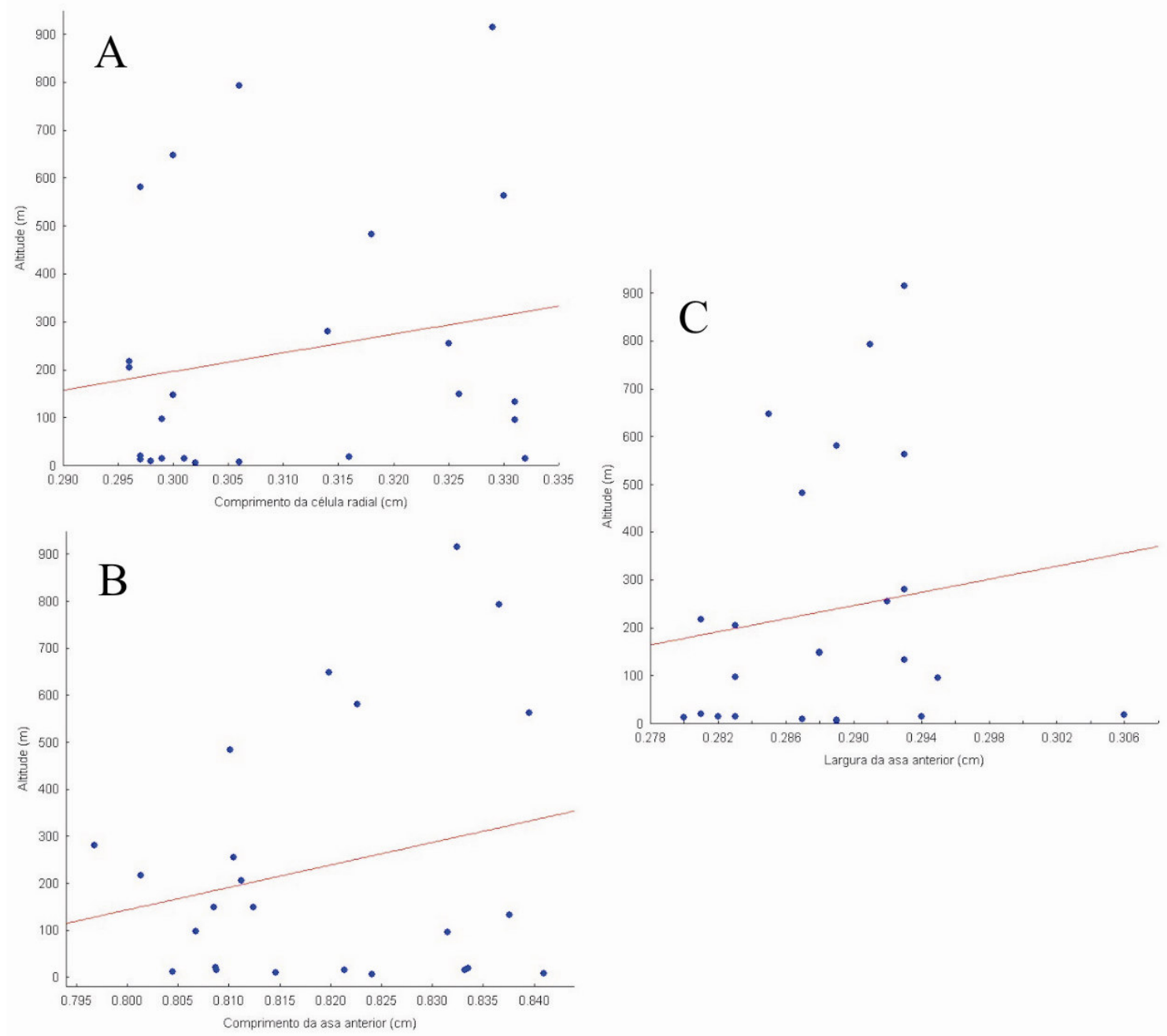

Figura 9: Regressões lineares entre as medidas de comprimento da célula radial (A) e de comprimento (B) e largura (C) da asa anterior em relação à altitude das localidades.

\subsection{2 - Morfometria geométrica.}

A partir dos 19 marcos anatômicos, as análises geraram 34 medidas de deformações relativas $(\mathbf{k}=2 \mathbf{n}-4$, sendo que $\mathbf{k}$ é igual ao número total de deformações relativas e $\mathbf{n}$ é igual ao número de marcos anatômicos).

Quando foram analisados os indivíduos, todas as 34 deformações relativas geradas contribuíram significantemente $(\alpha=0,05)$ para a discriminação dos grupos. A análise multivariada de variância (MANOVA) apresentou um valor $\lambda$ de Wilk $=0,025$, valor que indica diferenças altamente significantes $(\mathrm{P}<0,0001)$ entre os trinta grupos estudados $(A$. m. ligustica, A. m. carnica, A. m. mellifera, A. m. scutellata, Fernando de Noronha e as amostras de populações de abelhas africanizadas). 
As distâncias quadradas de Mahalanobis entre os centróides das distribuições de cada grupo se mostraram estatisticamente significantes (Tabela 3), exceto pela comparação das populações de Catolé do Rocha - PB (CR) com Rio de Janeiro - RJ (RJ), Severiano Melo - RN (SEM), Picos - PI (PI), Mossoró - RN (MO), Fortaleza - CE (FO) e Crato CE (CT) e também da população de Severiano Melo - RN (SEM) com Mossoró - RN (MO) e Crato - CE (CT). 
Tabela 3: Distâncias quadradas de Mahalanobis entre as populações estudadas (metade superior da tabela) e suas significâncias estatísticas (metade inferior da tabela). Os pontos em destaque indicam os pares de populações nas quais a distância entre os centróides não foi estatisticamente significante $(\alpha=0,05)$.

\begin{tabular}{ll|l|l|l|l|l|l|l|l|l|l|l|l|l|l|l|l|l|l|l|l|l|l|l|l|l|l|l|l|l|l|l|l|} 
RP-1968 & RP-2002 & RJ & SA & SM & SL & Aml & SE & SEM & SJ & TU & PA & PI & CR & MO & MA & FO & FL & CB & CR & BE & BA & AR & AJ & AQ & AL & Amm & Amc & Ams & FN \\
\hline
\end{tabular}

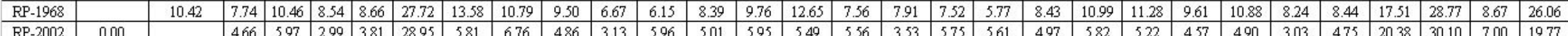

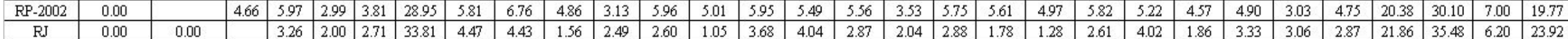

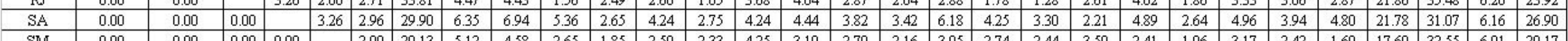

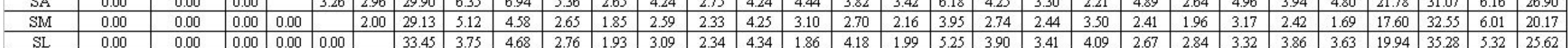

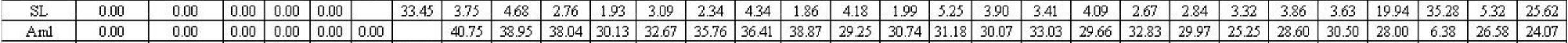

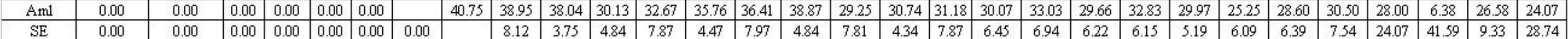

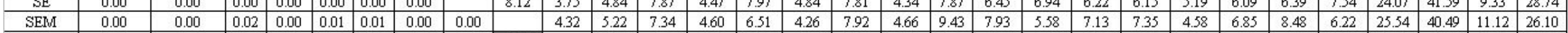

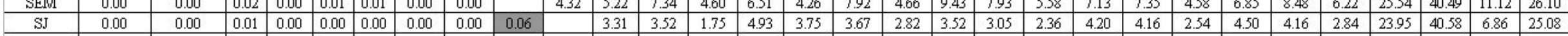

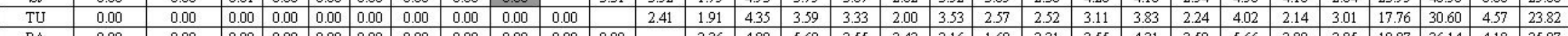

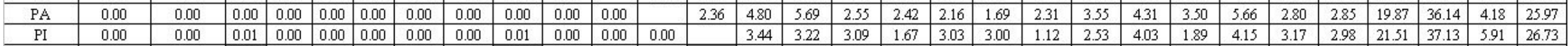

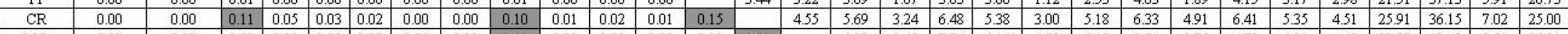

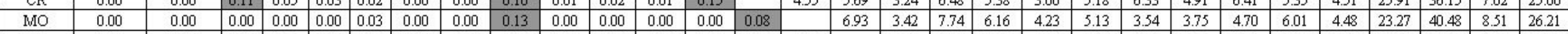

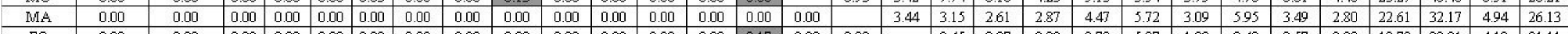

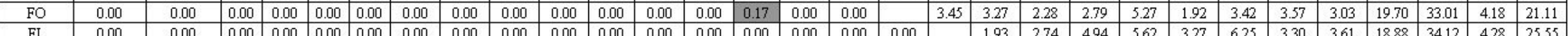

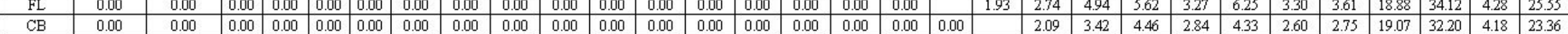

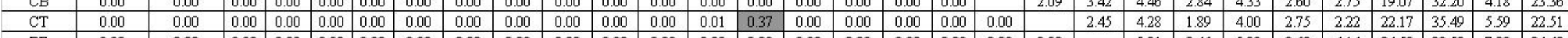

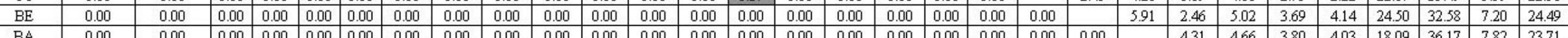

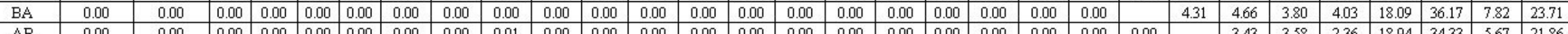

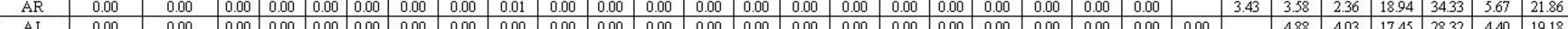

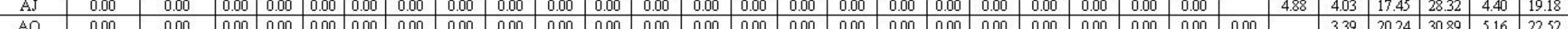

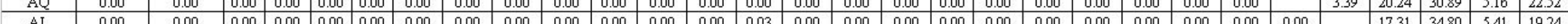

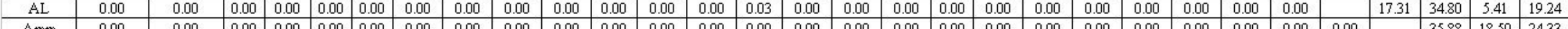

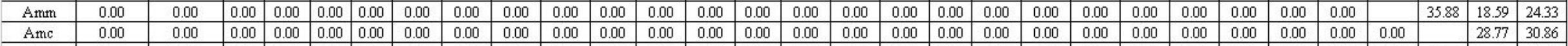

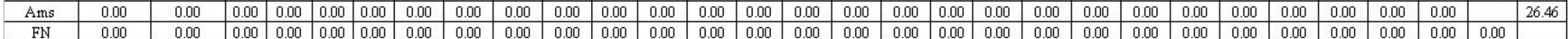


A Análise discriminante foi capaz de classificar 43,5\% dos indivíduos dentro de seu respectivo grupo (Tabela 4) e 36,5\% foram corretamente identificados nos testes de validação cruzada (Tabela 5). Estes valores foram obtidos dividindo-se o número de classificações e identificações corretas pelo número total de indivíduos. Merecem destaque os grupos de Ribeirão Preto - 1968 com 78,5\% na classificação e $76,2 \%$ na identificação, $A$. m. ligustica, com $91,8 \%$ na classificação e $85,6 \%$ na identificação, A. m. mellifera, com 96\% tanto na classificação quanto na identificação, Fernando de Noronha, com 96\% na classificação e $94 \%$ na identificação e por fim A. m. scutellata, com $62,1 \%$ nas classificações corretas e 55,7\% nas identificações corretas. Nota-se que as populações atuais de abelhas africanizadas apresentam-se com uma morfologia de asa muito próxima, uma vez que as classificações corretas giram entre $42 \%$ e $6,7 \%$, enquanto que as identificações corretas ficam entre $33 \%$ e $0 \%$.

A partir das distâncias quadradas de Mahalanobis foi também construído um dendograma de proximidade morfológica (Figura 10). Neste dendograma, as duas subespécies do ramo evolutivo C (Ruttner et al., 1978, Ruttner 1988) A. m. ligustica e A. m. carnica ficam agrupadas em um ramo separado e mais distante de todas as outras populações. Na seqüência, encontramos a população de Fernando de Noronha e no ramo seguinte A. m. mellifera. A população de Ribeirão Preto de 1968 é o próximo ramo, seguida por A. m. scutellata. Todas as populações de abelhas africanizadas são encontradas no próximo ramo, com subdivisões que se encontram de maneira relativamente coerente. As populações do nordeste brasileiro ficam agrupadas relativamente juntas, exceção às populações de Aracaju - SE e Tucano - BA, que ficam relativamente mais distantes. É possível identificar um ramo com todas as populações do Rio Grande do Norte e a população de São João da Boa Vista - SP, com outros ramos agrupando as outras populações nordestinas como ramos próximos deste primeiro. A população do Rio de Janeiro - RJ também fica agrupada no meio das populações nordestinas. Um ramo somente com as populações do sul do país também é observado neste dendograma. A população atual de Ribeirão Preto - SP fica agrupada juntamente com Tucano - BA e com 
Aquidauana - MS, sendo que Aracaju fica na base das populações africanizadas, em um ramo distinto. 
Tabela 4: Classificação de indivíduos dentro de seus respectivos grupos. As linhas representam as classificações esperadas e as colunas as classificações observadas. Em destaque estão os valores em porcentagem de indivíduos corretamente classificados dentro de seus grupos.

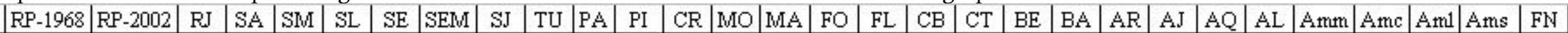
\begin{tabular}{|l|c|c|c|c|c|c|c|c|c|c|c|c|c|c|c|c|c|c|c|c|c|c|c|c|c|c|c|c|c|c|}
\hline RP-1968 & 78.5 & 1.4 & 0.5 & 0.0 & 1.9 & 0.0 & 0.0 & 0.0 & 0.5 & 0.0 & 1.4 & 1.4 & 0.0 & 0.0 & 0.0 & 2.8 & 0.5 & 2.3 & 1.4 & 0.9 & 0.0 & 0.9 & 0.9 & 0.0 & 0.5 & 1.9 & 0.9 & 0.0 & 1.4 & 0.0 \\
\hline
\end{tabular} \begin{tabular}{|l|l|l|l|l|l|l|l|l|l|l|l|l|l|l|l|l|l|l|l|l|l|l|l|l|l|l|l|l|l|l|}
\hline RP-2002 & 1.1 & 42.2 & 1.1 & 0.0 & 1.1 & 4.4 & 1.1 & 1.1 & 0.0 & 4.4 & 0.0 & 1.1 & 1.1 & 0.0 & 0.0 & 14.4 & 3.3 & 0.0 & 1.1 & 1.1 & 0.0 & 0.0 & 3.3 & 6.7 & 2.2 & 1.1 & 1.1 & 2.2 & 3.3 & 1.1 \\
\hline
\end{tabular}

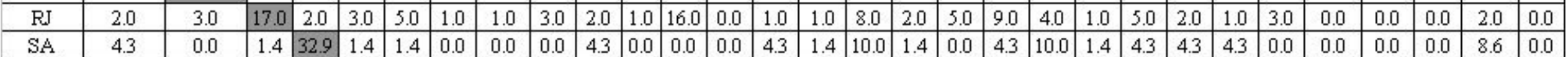

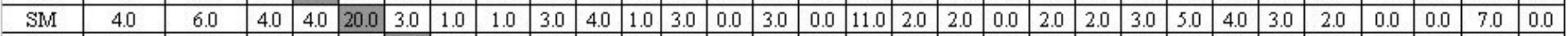

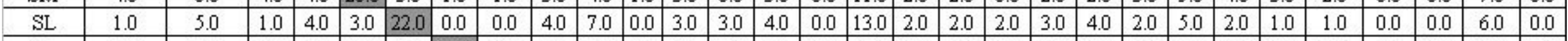

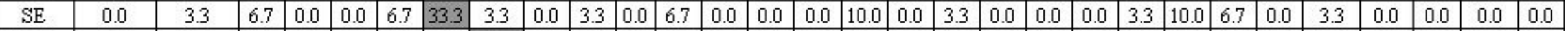

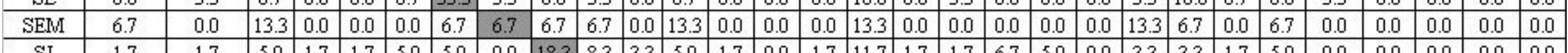

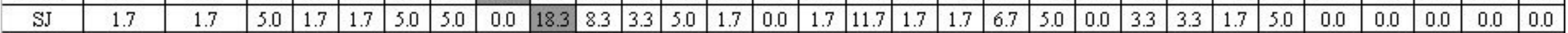

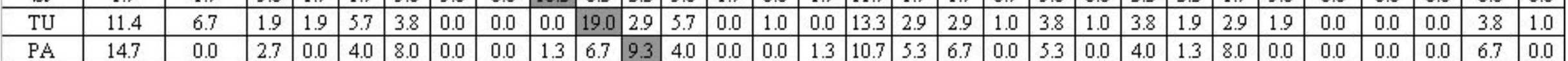

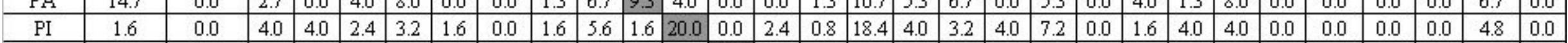

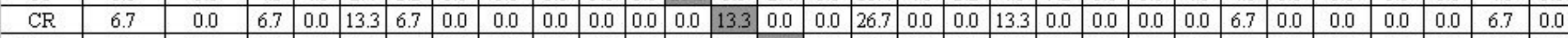
\begin{tabular}{l|l|l|l|l|l|l|l|l|l|l|l|l|l|l|l|l|l|l|l|l|l|l|l|l|l|l|l|l|l|l|}
\hline MO & 2.5 & 2.5 & 0.0 & 7.5 & 5.0 & 10.0 & 5.0 & 2.5 & 0.0 & 5.0 & 0.0 & 10.0 & 0.0 & 22.5 & 0.0 & 7.5 & 0.0 & 2.5 & 5.0 & 0.0 & 2.5 & 5.0 & 2.5 & 0.0 & 2.5 & 0.0 & 0.0 & 0.0 & 0.0 & 0.0 \\
\hline
\end{tabular}

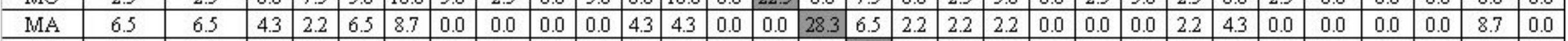
\begin{tabular}{|c|c|c|c|c|c|c|c|c|c|c|c|c|c|c|c|c|c|c|c|c|c|c|c|c|c|c|c|c|c|c|c|c|c|c|}
\hline FO & 5.0 & 3.5 & 1.5 & 2.0 & 1.0 & 2.5 & 1.0 & 1.5 & 2.0 & 2.5 & 1.5 & 7.0 & 0.0 & 1.0 & 1.0 & 41.0 & 2.5 & 0.5 & 1.0 & 4.0 & 0.0 & 4.5 & 2.5 & 3.0 & 1.0 & 0.5 & 0.0 & 0.0 & 6.5 & 0.0 \\
\hline
\end{tabular}

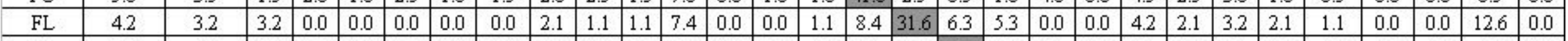

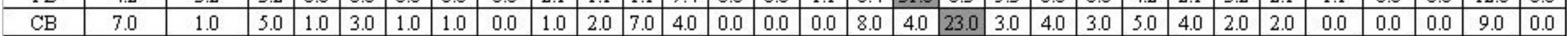

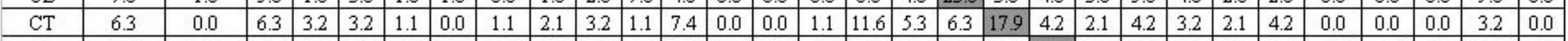

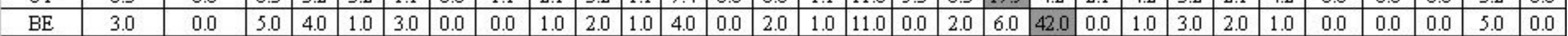

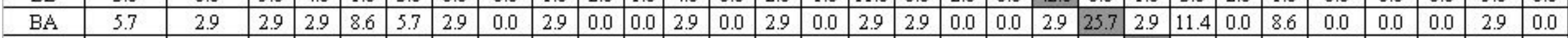

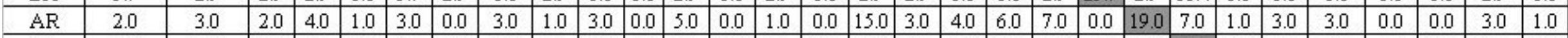

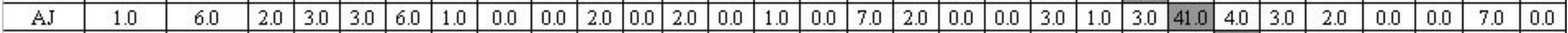
\begin{tabular}{|l|l|l|l|l|l|l|l|l|l|l|l|l|l|l|l|l|l|l|l|l|l|l|l|l|l|l|l|l|l|l|l|l|l|l}
\hline $\mathrm{AQ}$ & 5.3 & 10.5 & 1.1 & 2.1 & 1.1 & 1.1 & 0.0 & 0.0 & 2.1 & 3.2 & 3.2 & 3.2 & 0.0 & 1.1 & 0.0 & 3.2 & 5.3 & 5.3 & 3.2 & 6.3 & 3.2 & 2.1 & 2.1 & 28.4 & 1.1 & 0.0 & 0.0 & 0.0 & 6.3 & 0.0 \\
\hline
\end{tabular} \begin{tabular}{|l|l|l|l|l|l|l|l|l|l|l|l|l|l|l|l|l|l|l|l|l|l|l|l|l|l|l|l|l|l|l|}
\hline $\mathrm{AL}$ & 1.4 & 1.4 & 2.9 & 1.4 & 2.9 & 2.9 & 0.0 & 2.9 & 0.0 & 1.4 & 1.4 & 2.9 & 0.0 & 1.4 & 4.3 & 10.0 & 8.6 & 7.1 & 5.7 & 1.4 & 2.9 & 2.9 & 4.3 & 5.7 & 20.0 & 0.0 & 0.0 & 0.0 & 4.3 & 0.0 \\
\hline
\end{tabular} \begin{tabular}{|l|l|l|l|l|l|l|l|l|l|l|l|l|l|l|l|l|l|l|l|l|l|l|l|l|l|l|l|l|l|l|}
\hline Amm & 1.3 & 0.0 & 0.0 & 0.0 & 0.0 & 0.0 & 0.0 & 0.0 & 0.0 & 0.7 & 0.0 & 0.0 & 0.0 & 0.0 & 0.0 & 0.0 & 0.0 & 0.0 & 0.0 & 0.0 & 0.0 & 0.0 & 0.0 & 0.7 & 0.0 & 96.0 & 0.0 & 0.7 & 0.0 & 0.7 \\
\hline
\end{tabular}

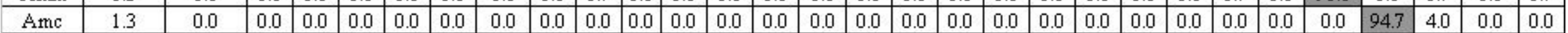
\begin{tabular}{l|l|l|l|l|l|l|l|l|l|l|l|l|l|l|l|l|l|l|l|l|l|l|l|l|l|l|l|l|l|l|}
\hline Aml & 0.0 & 0.0 & 0.0 & 0.0 & 0.0 & 0.0 & 0.0 & 0.0 & 0.0 & 0.0 & 0.0 & 0.0 & 0.0 & 0.0 & 0.0 & 0.0 & 0.0 & 0.0 & 0.0 & 0.0 & 0.0 & 0.0 & 0.0 & 0.0 & 0.0 & 0.0 & 8.2 & 91.8 & 0.0 & 0.0 \\
\hline
\end{tabular} \begin{tabular}{|l|l|l|l|l|l|l|l|l|l|l|l|l|l|l|l|l|l|l|l|l|l|l|l|l|l|l|l|l|l|l|l|l}
\hline Ams & 7.1 & 2.9 & 0.7 & 2.1 & 0.7 & 0.0 & 1.4 & 0.0 & 0.0 & 1.4 & 0.0 & 0.0 & 0.0 & 0.0 & 0.0 & 9.3 & 2.1 & 2.1 & 0.0 & 1.4 & 0.0 & 1.4 & 1.4 & 2.1 & 0.7 & 0.0 & 0.0 & 0.0 & 62.1 & 0.7 \\
\hline
\end{tabular}

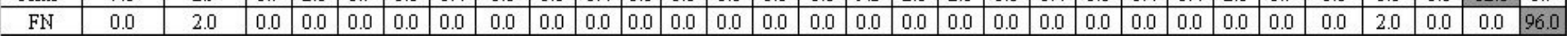


Tabela 5: Identificação de indivíduos por validação cruzada dentro de seus respectivos grupos. As linhas representam as classificações esperadas e as colunas as classificações observadas. Em destaque estão os valores em porcentagem de indivíduos corretamente classificados dentro de seus grupos.

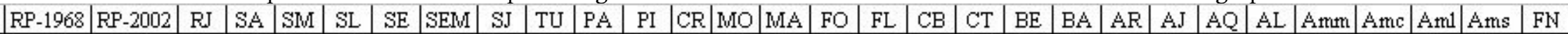

\begin{tabular}{|c|c|c|c|c|c|c|c|c|c|c|c|c|c|c|c|c|c|c|c|c|c|c|c|c|c|c|c|c|c|c|}
\hline-1968 & 5.2 & & & 0.0 & & 0.0 & & & & 0.5 & & 1.9 & 0.0 & 0.0 & 0.0 & 2.8 & 0.5 & 2.3 & 1.4 & 0.9 & 0.0 & 0.5 & 0.9 & 0.0 & 0.5 & 2.3 & 0.9 & 0.0 & 2.3 & 0.0 \\
\hline 20 & 2.2 & 289 & & 0.0 & & 4.4 & & & & 3.3 & & 3.3 & 1.1 & & 0.0 & 14.4 & \begin{tabular}{|l|l}
3.3 \\
\end{tabular} & 1.1 & 1.1 & 2.2 & 1.1 & 0.0 & 5.6 & 7.8 & 2.2 & 11 & 11 & 2.2 & & \\
\hline $\mathrm{RJ}$ & 2.0 & 10 & 0 & 2.0 & & 5.0 & & & & 2.0 & & 17.0 & \begin{tabular}{|l|}
0.0 \\
\end{tabular} & & .0 & 9.0 & 2.0 & & 9.0 & 0 & 1.0 & 0 & 2.0 & 1.0 & 30 & & 0 & .0 & 0 & 1.0 \\
\hline SA & t. & & 4 & 21.4 & 1.4 & 1.4 & & & & 8.1 & & 0.0 & \begin{tabular}{|l|}
0.0 \\
\end{tabular} & 4.3 & 1.4 & 10.0 & 1.4 & & 4.3 & 5.7 & 4 & 1.3 & 4.3 & 1.3 & & & .0 & .0 & 1.4 & 0.0 \\
\hline SM & & & 0 & 4.0 & 4.0 & 3.0 & & 1.0 & 4.0 & 4.0 & & 3.0 & 0.0 & 3.0 & 0.0 & 11.0 & 2.0 & 0 & 0.0 & .0 & 4.0 & 0 & 6.0 & 0 & & & .0 & 0 & 80 & 0.0 \\
\hline SL & & & & 4.0 & & 18.0 & & & & 7.0 & & 4.0 & 3.0 & & 10 & 14.0 & 2.0 & & 2.0 & 0 & 4.0 & .0 & 6.0 & 0 & & & & & & \\
\hline SE & & & & 0 & & 6.7 & & & & 3.3 & & 6.7 & 0.0 & & 100 & & \begin{tabular}{|l|l}
0.0 \\
\end{tabular} & & 0.0 & .0 & 0.0 & 3.3 & 133 & & & & & & & 0.0 \\
\hline SEM & & & 13.3 & 0.0 & 0.0 & 0.0 & 6.7 & 6.7 & 6.7 & 6.7 & 0.0 & 13.3 & \begin{tabular}{|l|}
0.0 \\
\end{tabular} & 0.0 & 0.0 & 13.3 & \begin{tabular}{|l|l} 
\\
\end{tabular} & 0 & 0.0 & 10 & 0.0 & 3.3 & 6.7 & 0.0 & & & .0 & & 1.0 & 0.0 \\
\hline SJ & & & 5.0 & 1.7 & 3 & 5.0 & & 0.0 & 0.0 & 8.3 & & 5.0 & 1.7 & 0.0 & 1.7 & 13.3 & \begin{tabular}{|l}
1.7 \\
\end{tabular} & 7 & 6.7 & 0 & 0.0 & 0 & 3.3 & 7 & & & .0 & & 1.0 & 0.0 \\
\hline TU & & & 1.9 & 2.9 & 3.7 & 3.8 & 0.0 & 0.0 & 0.0 & 12.4 & 2.9 & 5.7 & 0.0 & 1.0 & 0.0 & 13.3 & \begin{tabular}{|l}
2.9 \\
\end{tabular} & 2.9 & 1.9 & 4.8 & 1.0 & 3.8 & 1.9 & 3.8 & 1. & & & & & 1.0 \\
\hline PA & & & & 0 & & 8.0 & & & & 6.7 & $\frac{3}{2}$ & 4.0 & 0.0 & & 3 & 4.7 & 8.0 & & 0.0 & & 0.0 & 4.0 & 1.3 & & & & & & & 0.0 \\
\hline PI & & & & 4.0 & 2.4 & 3.2 & & 0.0 & 1.6 & 5.6 & 2.4 & 13.6 & 0.0 & 2.4 & 0.8 & 8.6 & 4.0 & 2 & 4.8 & .2 & 0 & 1.6 & 5.6 & 1.0 & & & & & & 1.0 \\
\hline $\mathrm{CR}$ & & & 6.7 & 0.0 & 13.3 & 6.7 & 0.0 & 0.0 & .0 & 6.7 & 0.0 & 0.0 & 0.0 & 0.0 & 0.0 & 20.0 & 0.0 & 10 & 13.3 & 0 & 0.0 & 0.0 & 0.0 & \begin{tabular}{|l}
6.7 \\
\end{tabular} & & & & & 17 & 0.0 \\
\hline MO & & & 0.0 & 7.5 & 7.5 & 15.0 & 5.0 & 2.5 & 0.0 & 5.0 & 0.0 & 12.5 & \begin{tabular}{|l|}
0.0 \\
\end{tabular} & 10.0 & 0.0 & 7.5 & 0.0 & 2.5 & 5.0 & 0.0 & 2.5 & 5.0 & 5.0 & 0.0 & 2 & & 10 & & J.0 & 0.0 \\
\hline MA & & & 4. & 4.3 & 6.5 & 8.7 & & 0.0 & 0.0 & 0.0 & 8 & \begin{tabular}{|l|l|}
4.3 \\
\end{tabular} & \begin{tabular}{|l|}
0.0 \\
\end{tabular} & 0.0 & 8.7 & 8.7 & \begin{tabular}{|l|l} 
\\
\end{tabular} & 4.5 & 2.2 & 0.0 & 0.0 & \begin{tabular}{|l}
2.2 \\
\end{tabular} & 2.2 & 4.3 & & & & & 0.9 & 0.0 \\
\hline FO & & & & 2 & 1 & 3.5 & & 2 & 2. & 3.0 & 5 & 9.0 & 0.0 & 1 & 1.0 & 30.5 & \begin{tabular}{|l}
3.0 \\
\end{tabular} & 0.5 & 1. & & & & .0 & & & & & & 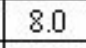 & 0.0 \\
\hline FL & & & & & ] & 0.0 & & U & 2. & 1.1 & 1 & 7.4 & 0.0 & 0.0 & 1.1 & 8.4 & 27.4 & 7.4 & 5.3 & & & 5 & 2.1 & & & & & & & 0.0 \\
\hline $\mathrm{CB}$ & & & 6.0 & 1.0 & 3.0 & 1.0 & 1.0 & 0.0 & 1.0 & 2.0 & 10.0 & 5.0 & \begin{tabular}{l|l}
0.0 \\
\end{tabular} & 0.0 & 1.0 & 7.0 & 7.0 & 3.0 & 3.0 & 4.0 & 3.0 & 5.0 & 4.0 & 2.0 & - & & $D$ & 10 & 0.0 & 0.0 \\
\hline CT & & & 6. & 3.2 & 4. & 1.1 & & 1 & 3. & 3.2 & 1 & 8.4 & 0.0 & & 1.1 & 12.6 & \begin{tabular}{|l}
6.3 \\
\end{tabular} & 6.3 & 11.6 & 4.2 & 2.1 & \begin{tabular}{|l}
4.2 \\
\end{tabular} & 3.2 & 2 & & & & & & 0.0 \\
\hline $\mathrm{BE}$ & 3 & & 6.0 & 5.0 & 1.0 & 4.0 & 0 & 0.0 & 1.0 & 2.0 & & 6.0 & 0.0 & 2.0 & 1.0 & 12.0 & 0.0 & & 7.0 & 10 & & \begin{tabular}{|l}
1.0 \\
\end{tabular} & 5.0 & 0 & & & & & 0 & 0.0 \\
\hline $\mathrm{BA}$ & & & 2. & 2.9 & 8. & 5.7 & 2 & 0.0 & 2. & 0.0 & & 2.9 & 0.0 & 8.6 & 0.0 & 5.7 & 2.9 & 0. & 0.0 & 2.9 & 14.3 & 2.9 & 11.4 & 0 & & & & & & 0.0 \\
\hline $\mathrm{AR}$ & & & 2 & 4.0 & 2 & 4.0 & 0 & & 1 & 3.0 & & 5.0 & \begin{tabular}{l|l}
0.0 \\
\end{tabular} & 1.0 & 0.0 & 18.0 & 4.0 & & 6.0 & & 0.0 & & 7.0 & & & & & & & 1.0 \\
\hline $\mathrm{AJ}$ & 1 & & 2. & 3.0 & 3. & 5.0 & 1 & 0 & 0. & 2.0 & & 2.0 & 0.0 & 2.0 & 0.0 & 9.0 & 2.0 & 0.0 & 1.0 & .0 & 2.0 & 4.0 & 30.0 & 5.0 & 4. & & & & 0 & 0.0 \\
\hline $\mathrm{AQ}$ & 5 & & 1.1 & 2.1 & 1.1 & 1.1 & 0 & 0.0 & 2.1 & 3.2 & 3 & 3.2 & 0.0 & 1.1 & 0.0 & 4.2 & 6. & & 3.2 & & & 1.1 & 2.1 & 3.2 & & & & & 4 & 0.0 \\
\hline $\mathrm{AL}$ & 1 & & 1.4 & 2.9 & 5.7 & 2.9 & 0 & 4 & 0 & 1.4 & 2.9 & 2.9 & 0.0 & 1.4 & 2.9 & 11.4 & 8.6 & & 5.7 & 2.9 & 2.9 & 2.9 & 4.3 & 5.7 & 11.4 & & & & 3 & 0.0 \\
\hline$A$ & & & 0 & 0.0 & 0 & 0.0 & 0 & U & & 0.7 & & 0.0 & \begin{tabular}{l|l}
0.0 \\
\end{tabular} & 0.0 & 20 & 0.0 & 0.0 & & 0.0 & & & & 0.0 & & & & & & & 0.7 \\
\hline & & & 0 & 0 & 0 & 0 & 0 & 0 & 0 & & & 0.0 & 0.0 & 0 & & 0 & & & & & & & & & & & & & & 1.0 \\
\hline And & 0 & & 0.0 & 0.0 & 0.0 & 0.0 & 0.0 & 0.0 & 0. & 0.0 & 0. & 0.0 & 0.0 & 0.0 & 0.0 & 0.0 & 0.0 & 0. & 0.0 & 0.0 & 0 & 0.0 & 1.0 & 0.0 & 0 & & 13.4 & 85.6 & 0 & 0.0 \\
\hline Ams & 8.6 & 2.9 & 0.7 & 2.1 & 1.4 & 0.0 & 1.4 & 0.0 & 0.0 & 1.4 & 0.7 & 0.0 & 0.0 & 0.0 & 0.0 & 12.1 & 2.1 & 2.9 & 0.0 & 1.4 & 0.0 & 1.4 & 1.4 & 2.1 & 0.7 & 0.0 & 0.0 & 0.0 & 55.7 & 0.7 \\
\hline & 0.0 & 2.0 & & 0.0 & & \begin{tabular}{|l|}
0.0 \\
\end{tabular} & & & & & & \begin{tabular}{|l|}
0.0 \\
\end{tabular} & \begin{tabular}{|l|}
0.0 \\
\end{tabular} & & & 0.0 & 00 & 0.0 & \begin{tabular}{|l|}
0.0 \\
\end{tabular} & $\mid 0.0$ & 0.0 & 0.0 & 0.0 & 0.0 & 0.0 & 0.0 & 2.0 & 2.0 & 0.0 & \\
\hline
\end{tabular}




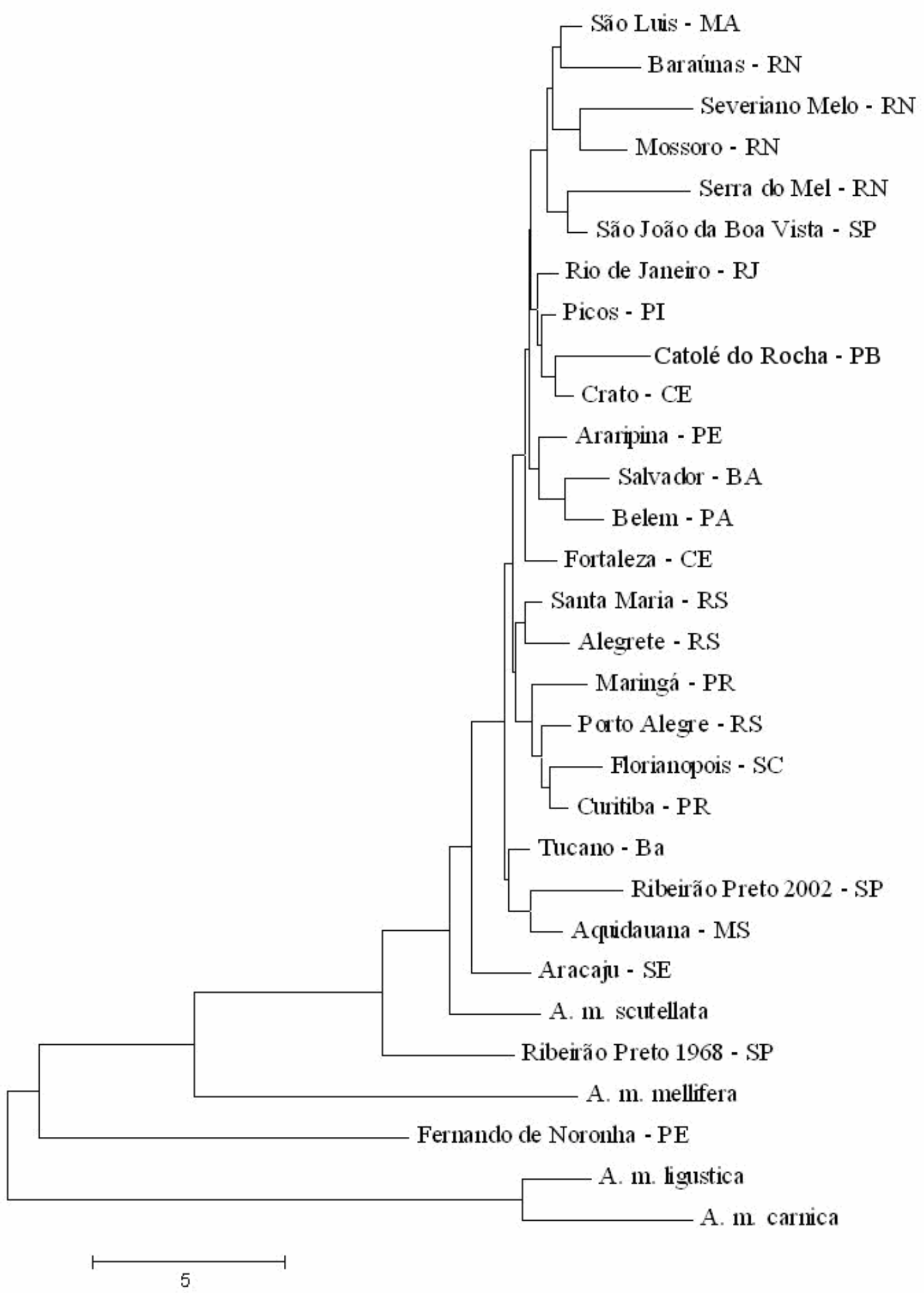

Figura 10: Dendograma de proximidade morfológica com as populações brasileiras de abelhas africanizadas e as subespécies ancestrais juntamente com a população européia de Fernando de Noronha. Características de todos os indivíduos foram utilizadas como base de dados.

A análise de discriminantes canônicas das 34 medidas de deformações relativas mostra um gráfico (Figura 11) onde os grupos estudados se apresentam de uma maneira 
bem definida, indicando claramente uma maior influência de $A . m$. scutellata nas populações africanizadas, uma vez que os centróides das distribuições destes grupos se mostram muito próximos. É interessante notar ainda que os grupos de A. m. ligustica e A.m. carnica se posicionam no lado oposto do gráfico de acordo com o eixo da primeira função discriminante, enquanto que $A$. m. mellifera apresenta o mesmo comportamento em relação às abelhas africanizadas, só que em relação ao eixo da segunda função discriminante. A população existente em Fernando de Noronha - PE apresenta-se isolada das demais populações, numa posição intermediária no triângulo formado pelo cluster de abelhas africanizadas $+A . m$. scutellata, A. m. mellifera e o cluster formado por A. m. ligustica e A. $m$. carnica. A população de Ribeirão Preto - 1968 fica posicionada um pouco afastada do cluster de abelhas africanizadas $+A$. m. scutellata, indicando uma maior influência das subespécies européias em seu perfil morfológico. 


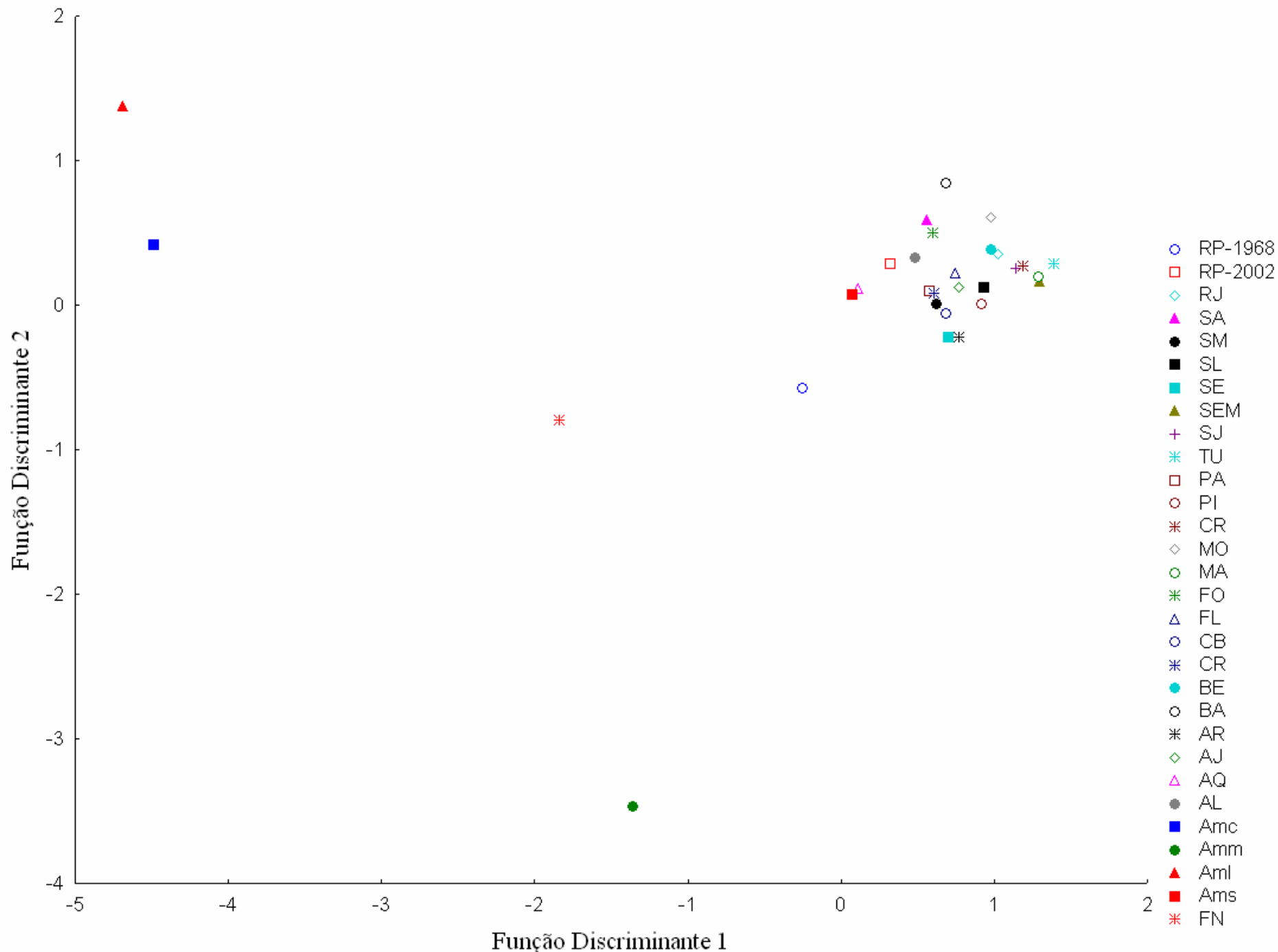

Figura 11: Análise de discriminantes canônicas das populações de abelhas africanizadas estudadas juntamente com as subespécies formadoras do híbrido e a população de abelhas italianas de Fernando de Noronha. 
A reconstrução gráfica dos formatos de asa de cada um dos grupos mostra uma diferença acentuada entre as subespécies, sendo que $A$. m. carnica e $A$. m. ligustica tem seus padrões de venação bastante parecidos quando comparadas entre si em relação aos outros grupos. As A. m. mellfera apresentam um padrão bem diferenciado das outras subespécies européias, mais próximo da subespécie africana que das ultimas. As abelhas de Fernando de Noronha - PE, apesar de sua origem européia, apresentam grandes diferenças quando comparadas com as outras subespécies européias, possuindo um perfil distinto (Figura 12). Já as populações de abelhas africanizadas apresentam uma enorme similaridade quando comparadas com as A. m. scutellata. Alguns exemplos são mostrados nas Figuras 13 e 14 . Um dos pontos de diferença entre quase todas as populações africanizadas e as $A . m$. scutellata é o posicionamento do marco anatômico 1, sendo a mudança nos outros marcos anatômicos não tão bem definida. A pequena variação apresentada pelas populações de abelhas africanizadas quanto ao deslocamento dos marcos anatômicos indica uma grande homogeneidade no tocante ao padrão de venação das asas anteriores. 


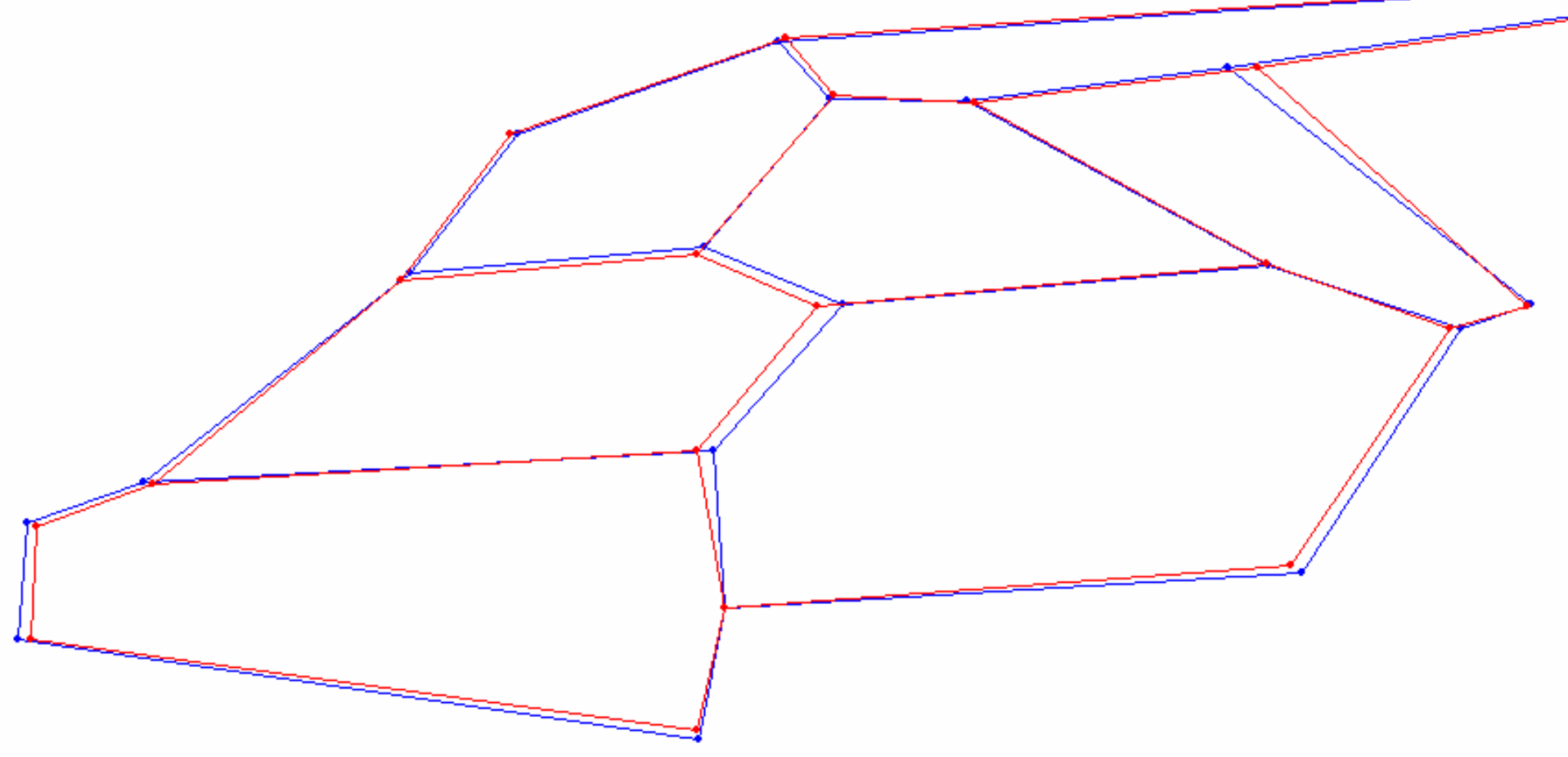

\section{$\mathrm{FN}>\mathrm{Aml}$}

Figura 12: Comparação do deslocamento dos marcos anatômicos nas subespécies de A. mellifera e nas populações de Fernando de Noronha e Ribeirão Preto - 1968. Nas reconstruções, o nome do primeiro grupo sempre corresponde ao formato em vermelho enquanto o segundo grupo corresponde ao formato em azul. 


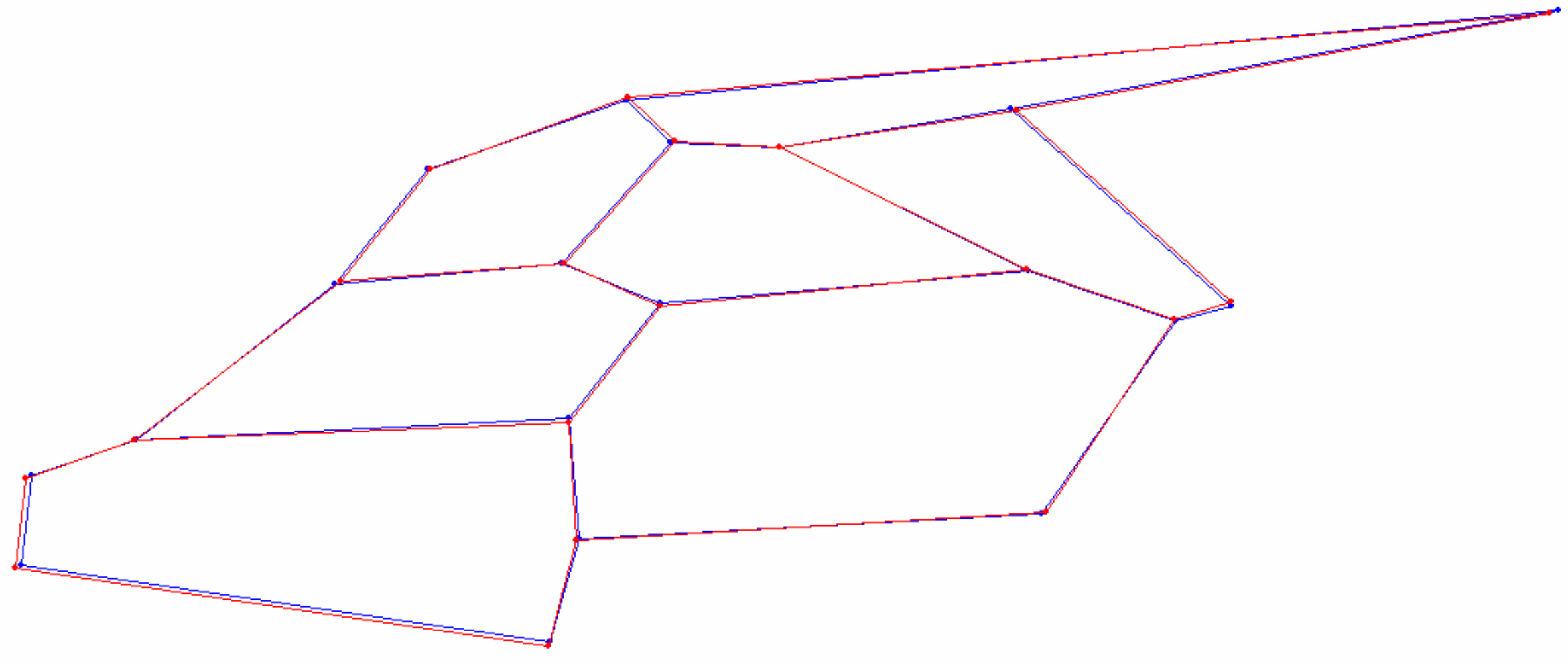

Ams $>$ AQ

Figura 13: Comparação do deslocamento dos marcos anatômicos na população de abelhas africanizadas de Aquidauana - MS em comparação com $A$. $m$. scutellata. Na reconstrução, $A$. m. scutellata corresponde ao formato em vermelho e a população de Aquidauana - MS corresponde ao formato em azul. 


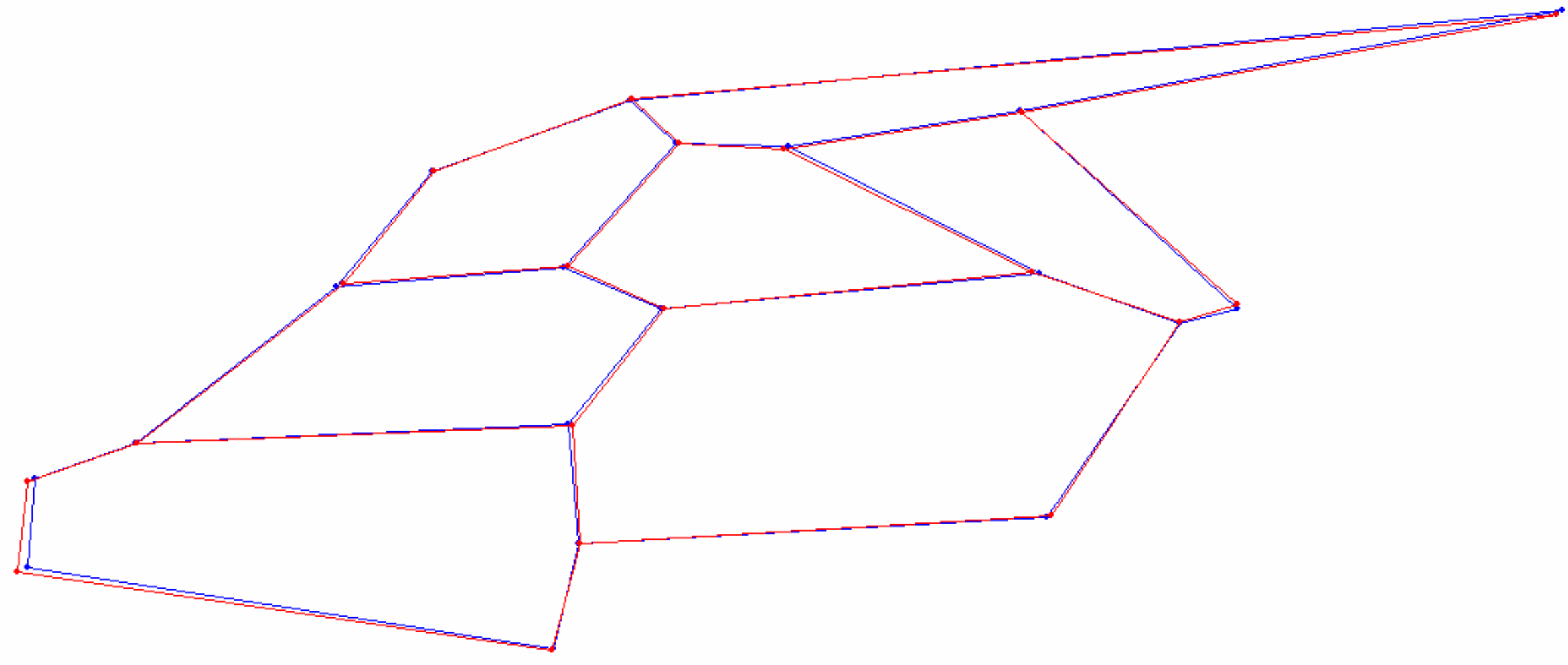

Ams $>$ RJ

Figura 14: Comparação do deslocamento dos marcos anatômicos na população de abelhas africanizadas do Rio de Janeiro - RJ em comparação com $A$. m. scutellata. Na reconstrução, A. m. scutellata corresponde ao formato em vermelho e a população do Rio de Janeiro - RJ corresponde ao formato em azul. 
Uma vez que a variação de deslocamento dos marcos anatômicos entre as populações atuais de abelhas africanizadas é pequena, uma análise adicional foi feita, onde as populações de A. m. mellifera, A. m. carnica, A. m. ligustica, A. m. scutellata, Fernando de Noronha e Ribeirão Preto - 1968 foram retiradas da amostra para uma estimativa das distâncias quadradas de Mahalanobis corrigidas entre os centróides das distribuições de cada população. Assim, somente as atuais populações brasileiras existentes foram avaliadas sem a presença de grupos externos para que o poder discriminatório da técnica de deformações relativas pudesse ser testado quanto à discriminação de populações de abelhas africanizadas.

Desta maneira, dentre as 34 deformações relativas geradas, 32 contribuíram significantemente $(\alpha=0,05)$ para a separação dos grupos. A MANOVA utilizando-se das 34 deformações relativas demonstrou a presença de diferenças estatísticas significantes entre os grupos $(\lambda$ de Wilk $=0,224 \mathrm{P}<0,001)$.

As distâncias quadradas de Mahalanobis corrigidas entre os centróides das distribuições de cada grupo se mostraram estatisticamente significantes $(\alpha=0,05)$ (Tabela 6), exceto pela comparação das populações de Catolé do Rocha - PB (CR) com Rio de Janeiro - RJ (RJ), Severiano Melo - RN (SEM), Picos - PI (PI), Mossoró - RN (MO), Fortaleza - CE (FO) e Crato - CE (CT) e também da população de Severiano Melo - RN (SEM) com Mossoró - RN (MO) e Crato - CE (CT), sendo estas as mesmas populações que não apresentaram diferenças estatísticas quando as amostras foram avaliadas com as subespécies incluídas. 
Tabela 6: Distâncias quadradas de Mahalanobis corrigidas (sem a população de Fernando de Noronha e as subespécies puras) entre as populações estudadas (metade superior da tabela) e suas significâncias estatísticas (metade inferior da tabela). Os pontos em destaque indicam os pares de populações nas quais a distância entre os centróides não foi estatisticamente significante $(\alpha=0,05)$.

\begin{tabular}{|c|c|c|c|c|c|c|c|c|c|c|c|c|c|c|c|c|c|c|c|c|c|c|c|c|}
\hline & 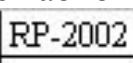 & $\mathrm{RJ}$ & SA & SM & $\mathrm{SL}$ & SE & SEM & SJ & TU & PA & PI & $\mathrm{CR}$ & MO & MA & FO & FL & $\mathrm{CB}$ & $\mathrm{CT}$ & $\mathrm{BE}$ & BA & $\mathrm{AR}$ & $\mathrm{AJ}$ & $\mathrm{AQ}$ & $\mathrm{AL}$ \\
\hline P-2002 & & 4.93 & 6.41 & 3.28 & 4.59 & 6.7 & 6.92 & 5.28 & 3.59 & 6.6 & 5.59 & 6.35 & 6.38 & 5.55 & 4.14 & 6.02 & 5.8 & 5.32 & 5.96 & 5.74 & 5.02 & 5.03 & 3.34 & 5.22 \\
\hline RJ & .000 & & 22 & 1.93 & 57 & 4.46 & 4.28 & 1.46 & 2.49 & 2.68 & 0.99 & 3.56 & 3.81 & 2.75 & 2.01 & 2.84 & 1.76 & 1.28 & 58 & 3.94 & 1.77 & 3.36 & 94 & 2.90 \\
\hline SA & & 000 & & 3.2 & 2.78 & 6.24 & 6.46 & 5.21 & 2.6 & 4.37 & 2.68 & 4.35 & 4.03 & 3.95 & 3.57 & 6.31 & 1.29 & 35 & 19 & 4 & 2.62 & 5.08 & 88 & 4.88 \\
\hline SM & & 000 & 100 & & 1.87 & 5.08 & 4.34 & 2.45 & 1.85 & 2.58 & 2.24 & 4.16 & 2.83 & 2.61 & 2.19 & 3.9 & 67 & & 3.33 & 2.29 & & & 2.3 & \\
\hline SL & & 100 & 000 & 000 & & 4 & 4.51 & 2.73 & 1.8 & 93 & 2.24 & 4.29 & 1.86 & 3.93 & 1.98 & 4.98 & 58 & 24 & 78 & 2.63 & 2.68 & & & 3.6 \\
\hline $\mathrm{SE}$ & & 000 & 000 & 000 & 0.000 & & 8.14 & 3.87 & 4.92 & 8.13 & 4.52 & 17 & 4.96 & 7.89 & 4.44 & 7.81 & 6.44 & .05 & 5.97 & 6.36 & 4.99 & & & 7.8 \\
\hline SEM & & 029 & 900 & 024 & 0.016 & .000 & & 4.39 & 4.99 & 7.11 & 4.41 & 6.14 & 4.17 & 7.55 & 4.33 & 9.07 & 7.5 & 5.28 & 6.61 & 7.3 & 4.25 & 6.92 & .96 & 6.2 \\
\hline SJ & & 020 & 000 & 000 & 000 & 0.000 & 0.050 & & 3.29 & 3.5 & 1.66 & 4.75 & 3.68 & 3.46 & 2.69 & 3.35 & 88 & 2.21 & 3.83 & 4.2 & 2.32 & 7.32 & 78 & 2.81 \\
\hline TU & & 000 & 000 & 000 & 000 & 0.000 & 0.004 & 0.000 & & 2.49 & 1.91 & 4.41 & 3.4 & 3.34 & 2.16 & 3.55 & 2.5 & 2.59 & 3.09 & 68 & 2.25 & & 2.04 & 3.18 \\
\hline PA & & 1.000 & 000 & .000 & .000 & 0.000 & 0.000 & 0.000 & 0.000 & & 2.41 & 4.87 & 5.5 & 2.48 & 2.54 & 2.25 & 1.71 & 2.45 & 3.76 & 4.18 & 3.66 & .78 & 2.7 & 2.98 \\
\hline PI & & 0.019 & 0.000 & 0.000 & 0.000 & 0.000 & 0.015 & 0.001 & 0.000 & 000 & & 3.37 & 3.11 & 2.92 & 1.68 & & 2.9 & 1.14 & 2.48 & 4.02 & 1.8 & & 3 & 2.99 \\
\hline $\mathrm{CR}$ & & 0.142 & 0.041 & 0.038 & 0.028 & 0.000 & 0.159 & 0.022 & 0.019 & 0.010 & 0.175 & & 4.41 & 5.63 & 3.22 & 6.43 & 5.3 & 2.86 & 5.06 & 6.3 & 4.79 & 6.25 & 5.23 & 4.4 \\
\hline MO & & 0.000 & .000 & 0.000 & 0.032 & 0.000 & 0.159 & 0.000 & 0.000 & 0.000 & 0.000 & 0.106 & & 6.59 & 3.3 & 7.34 & 5.74 & 4.02 & 4.56 & 3.51 & 3.43 & 4.71 & 5.5 & 4.39 \\
\hline MA & & 0.000 & 000 & 0.000 & 0.000 & 0.000 & 0.000 & 0.000 & 0.000 & 001 & 0.000 & 0.005 & 0.000 & & 3.44 & 3.03 & 2.53 & 2.79 & 4.52 & 5.44 & 3.06 & 5.87 & 3.3 & 2.78 \\
\hline $\mathrm{FO}$ & & 0.000 & 000 & 0.000 & 0.000 & 0.000 & 0.012 & 0.000 & 0.000 & 000 & 000 & 0.183 & 0.000 & 0.000 & & 3.45 & 3.26 & 2.3 & 2.87 & 5.22 & 2 & 3.47 & 3.5 & 3.10 \\
\hline FL & & 0.000 & 000 & 0.000 & 0.000 & 0.000 & 0.000 & 0.000 & 0.000 & 000 & 000 & 000 & 0.000 & 0.000 & 0.000 & & 1.93 & 2.86 & 5.12 & 5.46 & 3.29 & 6.13 & 3.27 & 3.60 \\
\hline CB & & 0.000 & 000 & 0.000 & 0.000 & 0.000 & 0.000 & 0.000 & 0.000 & 000 & 000 & 0.002 & 0.000 & 0.000 & 0.000 & 0.000 & & 2.12 & 3.5 & 4.17 & 2.82 & 4.19 & 2.48 & 2.7 \\
\hline CT & & 0.004 & 000 & 0.000 & 0.000 & 0.000 & 0.002 & 0.000 & 0.000 & 000 & 1.005 & 458 & 1.000 & 0.000 & 0.000 & 0.000 & 0.000 & & 2.5 & 4.24 & 1.91 & 3.84 & 2.68 & 2.19 \\
\hline $\mathrm{BE}$ & & 0.000 & 0.000 & 0.000 & 0.000 & 0.000 & 0.000 & 0.000 & 0.000 & 000 & 0.000 & .003 & 0.000 & 0.000 & 0.000 & 0.000 & 0.000 & 0.000 & & 5.66 & 2.45 & 4.88 & 3.6 & 4.02 \\
\hline $\mathrm{BA}$ & & 0.000 & 0.000 & 0.009 & 0.001 & 0.000 & 0.000 & 0.000 & 0.000 & 000 & 0.000 & 0.003 & 0.002 & 0.000 & 0.000 & 0.000 & 0.000 & 0.000 & 0.000 & & 4.21 & 4.64 & 3.5 & 4.03 \\
\hline $\mathrm{AR}$ & & 0.000 & 000 & 0.000 & 0.000 & 0.000 & 0.031 & 0.000 & 0.000 & 0.000 & 0.000 & 0.007 & 0.000 & 0.000 & 0.000 & 0.000 & 0.000 & 0.000 & 0.000 & 0.000 & & 3.46 & 53 & 2.4 \\
\hline $\mathrm{AJ}$ & & 0.000 & 000 & 000 & 0.000 & 0.000 & 0.000 & 0.000 & 0.000 & 0.000 & .000 & 1.000 & 0.000 & 0.000 & 0.000 & 0.000 & 0.000 & 0.000 & 0.000 & 0.000 & .000 & & 4.63 & 3.89 \\
\hline $\mathrm{AQ}$ & & 0.000 & 0.000 & 1.000 & 0.000 & 0.000 & 0.000 & 0.000 & 0.000 & 0.000 & .000 & 0.002 & 0.000 & 0.000 & 0.000 & 0.000 & 0.000 & 0.000 & 0.000 & 0.000 & 1.000 & .000 & & 3.27 \\
\hline $\mathrm{AL}$ & 000 & 0.000 & .000 & .000 & 0.000 & 0.000 & .000 & 0.000 & 0.000 & 0.000 & .000 & 1.033 & .000 & 0.000 & 0.000 & 0.000 & 0.000 & 0.000 & 0.000 & 0.000 & 0.000 & 0.000 & 0000 & \\
\hline
\end{tabular}


De acordo com as análises discriminantes, 29,4\% dos indivíduos foram corretamente classificados dentro de seus respectivos grupos (Tabela 7) e 21,4\% dos indivíduos foram corretamente identificados (Tabela 8) nos testes de validação cruzada, com destaque para as populações de Ribeirão Preto 2002 - SP, com 53\% de classificações corretas e 47\% na identificação, Belém - PA (BE), com 47\% de classificações corretas e 34\% na identificação, Aracaju - SE (AJ), com 46\% nas classificações corretas e 36\% na identificação e Fortaleza - CE (FO), com 45\% nas classificações corretas e 38,5\% na identificação de seus indivíduos. É interessante notar que os valores, tanto nas classificações quanto nas identificações corretas no nível populacional dos grupos atualmente existentes são bem menores do que as taxas apresentadas pelas classificações subespecíficas (Tabelas 4, 5, 7 e 8).

O dendograma de proximidade morfológica construído a partir das distâncias de Mahalanobis corrigidas (Figura 15) entre as diversas localidades brasileiras amostradas (Tabela 6) apresentou-se dividido em três ramos. Um deles mostra as populações do sul do Brasil agrupadas (Alegrete - RS, Maringá - PR, Porto Alegre - RS, Florianópolis - SC e Curitiba - PR), com exceção de Santa Maria - RS. Um sub-ramo lateral composto pelas populações de Crato - CE e Catolé do Rocha - PB apresenta-se mais próximo das populações do Sul do Brasil. O segundo grande ramo agrupa três das quatro populações amostradas no Rio Grande do Norte (Baraúna, Mossoró e Severiano Melo). Curiosamente, a população de Santa Maria - RS sai agrupada neste ramo juntamente com a população de Baraúna - RN. Assim como no dendograma anterior (Figura 10), as populações de Tucano - BA, Ribeirão Preto - SP e Aquidauana - MS saem novamente incluídas no mesmo grupo. No terceiro ramo, as populações de São João da Boa Vista - SP e Rio de Janeiro - RJ novamente saem agrupadas junto com as populações do norte e nordeste do Brasil (Picos PI, Serra do Mel - RN, Salvador - BA, Belém - PA e Araripina - PE). 
Tabela 7: Classificação de indivíduos dentro de seus respectivos grupos de acordo com as análises discriminantes. As linhas representam as classificações esperadas e as colunas as classificações observadas. Estão destacados os valores em porcentagem de indivíduos corretamente classificados dentro de seus grupos.

\begin{tabular}{|l|l|l|l|l|l|l|l|l|l|l|l|l|l|l|l|l|l|l|l|l|l|l|l|} 
RP-2002 & RJ & SA & SM & SL & SE & SEM & SJ & TU & PA & PI & CR & MO & MA & FO & FL & CB & CR & BE & BA & AR & AJ & AQ & AL \\
\hline
\end{tabular}

\begin{tabular}{|c|c|c|c|c|c|c|c|c|c|c|c|c|c|c|c|c|c|c|c|c|c|c|c|c|}
\hline & & & & & & & & & & & & & & & & & & & & & & & & \\
\hline RP-2002 & 53.0 & 1.0 & 1.0 & 1.0 & 3.0 & 1.0 & 1.0 & 0.0 & 5.0 & 0.0 & 0.0 & 1.0 & 0.0 & 0.0 & 13.0 & 3.0 & 0.0 & 1.0 & 1.0 & 0.0 & 1.0 & 8.0 & 6.0 & \\
\hline $\mathrm{RJ}$ & 5.0 & 13.0 & 3.0 & 3.0 & 4.0 & 2.0 & 1.0 & 4.0 & 2.0 & 2.0 & 15.0 & 0.0 & 1.0 & 3.0 & 10.0 & 2.0 & 7.0 & 7.0 & 4.0 & 1.0 & 4.0 & 2.0 & 1.0 & 4.0 \\
\hline SA & 1.0 & 0.0 & 31.4 & 1.4 & 0.0 & 0.0 & 0.0 & 0.0 & 5.7 & 5.7 & 0.0 & 0.0 & 4.3 & 1.4 & 8.6 & 2.9 & 1.4 & 2.9 & 17.1 & 2.9 & 5.7 & 4.3 & 4.3 & 0.0 \\
\hline SM & 0 & .0 & 3.0 & 22.0 & 4.0 & 1.0 & 1.0 & 3.0 & 6.0 & 3.0 & 3.0 & 0.0 & 2.0 & 0.0 & 1.0 & 1.0 & 4.0 & 1.0 & 1.0 & 3.0 & 3.0 & 6.0 & 6.0 & 5.0 \\
\hline SL & .0 & 3.0 & 4.0 & 2.0 & 23.0 & 0.0 & 1.0 & 4.0 & 6.0 & 0.0 & 4.0 & 3.0 & 3.0 & 0.0 & 16.0 & 2.0 & 2.0 & 2.0 & 3.0 & 4.0 & 2.0 & 5.0 & 3.0 & 8.0 \\
\hline $\mathrm{SE}$ & 3 & 3 & 0.0 & 0.0 & 6.7 & 36.7 & 3.3 & 0.0 & 3.3 & 0.0 & 6.7 & 0.0 & 0.0 & 0.0 & 10.0 & 0.0 & 6.7 & 0.0 & 0.0 & 0.0 & 3.3 & 10.0 & 6.7 & 0.0 \\
\hline SEM & 6.7 & 6.7 & 0.0 & 0.0 & 0.0 & 6.7 & 6.7 & 6.7 & 6.7 & 0.0 & 13.3 & 0.0 & 0.0 & 0.0 & 20.0 & 0.0 & 0.0 & 0.0 & 0.0 & 0.0 & 20.0 & \begin{tabular}{|l|l|} 
\\
\end{tabular} & 0.0 & 6.7 \\
\hline SJ & 3 & 3.3 & 1.7 & 1.7 & 3.3 & 3.3 & 0.0 & 18.3 & 10.0 & 3.3 & 5.0 & 1.7 & 0.0 & 1.7 & 13.3 & 1.7 & 1.7 & 8.3 & 5.0 & 0.0 & 1.7 & 3.3 & 1.7 & 6.7 \\
\hline TU & 7.6 & 2.9 & 2.9 & 6.7 & 5.7 & 0.0 & 0.0 & 0.0 & 24.8 & 2.9 & 6.7 & 0.0 & 1.0 & 0.0 & 14.3 & 3.8 & 1.9 & 1.0 & 5.7 & 0.0 & 3.8 & 3.8 & 3.8 & 1.0 \\
\hline PA & 0 & 1.3 & 0.0 & 5.3 & 10.7 & 0.0 & 0.0 & 1.3 & 5.3 & 14.7 & 6.7 & 0.0 & 0.0 & 2.7 & 10.7 & 5.3 & 10.7 & 1.3 & 6.7 & 0.0 & 4.0 & 2.7 & 10.7 & 0.0 \\
\hline PI & 1.8 & 4.0 & 3.2 & 2.4 & 3.2 & 1.6 & 0.0 & 1.6 & 5.6 & 2.4 & 20.8 & 0.0 & 2.4 & 1.6 & 18.4 & 4.8 & 5.6 & 4.0 & 7.2 & 0.0 & 1.6 & 4.8 & 4.0 & 0.0 \\
\hline $\mathrm{CR}$ & 7 & 6.7 & 0.0 & 13.3 & 6.7 & 0.0 & 0.0 & 0.0 & 0.0 & 0.0 & 0.0 & 13.3 & 0.0 & 0.0 & 33.3 & 0.0 & 0.0 & 13.3 & 0.0 & 0.0 & 0.0 & 0.0 & 6.7 & 0.0 \\
\hline $\mathrm{MO}$ & 2.5 & 2.5 & 5.0 & 5.0 & 15.0 & 5.0 & 0.0 & 0.0 & 5.0 & 0.0 & 10.0 & 0.0 & 20.0 & 0.0 & 7.5 & 0.0 & 2.5 & 5.0 & 0.0 & 2.5 & 5.0 & 5.0 & 0.0 & 2.5 \\
\hline MA & 6.5 & 4.3 & 2.2 & 6.5 & 8.7 & 0.0 & 0.0 & 0.0 & 0.0 & 4.3 & 4.3 & 0.0 & \begin{tabular}{|l|}
0.0 \\
\end{tabular} & 28.3 & 13.0 & 2.2 & 6.5 & 2.2 & 2.2 & 0.0 & 2.2 & 0.0 & 4.3 & 2.2 \\
\hline $\mathrm{FO}$ & 5.0 & 1.5 & 2.0 & 2.0 & 2.5 & 1.5 & 2.0 & 1. & 3.5 & 1.5 & 7.0 & 0.0 & 0.5 & 1.0 & 45.0 & 5.0 & 1.0 & 1.5 & 6.0 & 0.0 & 4.5 & 1.5 & 2.5 & 1.5 \\
\hline $\mathrm{FL}$ & 5.3 & \begin{tabular}{|l|}
3.2 \\
\end{tabular} & 0.0 & 0.0 & 0.0 & 0.0 & 0.0 & 3.2 & 1.1 & 3.2 & 8.4 & 0.0 & 0.0 & 1.1 & 7.4 & 40.0 & 8.4 & 4.2 & 1.1 & 0.0 & 3.2 & 2.1 & 3.2 & 5.3 \\
\hline $\mathrm{CB}$ & 2 & 6.0 & 2.0 & 3.0 & 1.0 & 0.0 & 0.0 & 2. & 4.0 & 7.0 & 3. & 0.0 & 0.0 & 1.0 & 10.0 & 9.0 & 27.0 & 3.0 & 4.0 & 3.0 & 5.0 & 5.0 & 1.0 & 2.0 \\
\hline $\mathrm{CR}$ & 2.1 & 8.4 & 3.2 & 2.1 & 1.1 & 1.1 & 1.1 & 1.1 & 3.2 & 1.1 & 6.3 & 0.0 & 0.0 & 2.1 & 12.6 & 7.4 & 6.3 & 17.9 & 4.2 & 2.1 & 6.3 & 1.1 & 5.3 & 4.2 \\
\hline$B$ & 0.0 & 6.0 & 3.0 & 2.0 & 2.0 & 0.0 & 0.0 & 1. & 2.0 & 1.0 & 7.0 & 0.0 & 1.0 & 1.0 & 12.0 & 1.0 & 1.0 & 4.0 & 47.0 & 0.0 & 0.0 & 4.0 & 3.0 & 2.0 \\
\hline $\mathrm{BA}$ & 5.7 & 2.9 & 2.9 & 8.6 & 8.6 & 2.9 & 0.0 & 0.0 & 2.9 & 0.0 & 2.9 & 0.0 & 2.9 & 0.0 & 5.7 & 2.9 & 0.0 & 0.0 & 2.9 & 20.0 & 5.7 & 14.3 & 2.9 & 5.7 \\
\hline $\mathrm{AR}$ & 3.0 & 1.0 & 4.0 & 1.0 & 3.0 & 0.0 & 2.0 & 1.0 & 3.0 & 1.0 & 7.0 & 0.0 & 1.0 & 0.0 & 14.0 & 3.0 & 6.0 & 9.0 & 7.0 & 0.0 & 22.0 & \begin{tabular}{|l|}
7.0 \\
\end{tabular} & 1.0 & 4.0 \\
\hline $\mathrm{AJ}$ & 7.0 & 1.0 & 3.0 & 4.0 & 4.0 & 1.0 & 0.0 & 0.0 & 2.0 & 1.0 & 1.0 & 0.0 & 1.0 & 1.0 & 11.0 & 2.0 & 2.0 & 0.0 & 3.0 & 1.0 & 2.0 & 46.0 & 3.0 & 4.0 \\
\hline $\mathrm{AQ}$ & 10.5 & \begin{tabular}{|l}
1.1 \\
\end{tabular} & 3.2 & 2.1 & 2.1 & 0.0 & 0.0 & 2.1 & 3.2 & 3.2 & 2.1 & 0.0 & 2.1 & 0.0 & 5.3 & 8.4 & 7.4 & 3.2 & 5.3 & 2.1 & 2.1 & \begin{tabular}{|l|}
4.2 \\
\end{tabular} & 29.5 & 1.1 \\
\hline $\mathrm{AL}$ & 1.4 & 2.9 & 2.9 & 1.4 & 4.3 & 0.0 & 1.4 & 0.0 & 1.4 & 2.9 & 2.9 & 0.0 & 1.4 & 4.3 & 11.4 & 8.6 & 7.1 & 5.7 & 2.9 & \begin{tabular}{|l|}
1.4 \\
\end{tabular} & 2.9 & 5.7 & 5.7 & 21.4 \\
\hline
\end{tabular}


Tabela 8: Identificação de indivíduos por validação cruzada dentro de seus respectivos grupos. As linhas representam as classificações esperadas e as colunas as classificações observadas. Em destaque estão os valores em porcentagem de indivíduos corretamente classificados dentro de seus grupos.

\begin{tabular}{|c|c|c|c|c|c|c|c|c|c|c|c|c|c|c|c|c|c|c|c|c|c|c|c|c|}
\hline & RP-2002 & $\mathrm{RJ}$ & SA & $M$ & SL & SE & SEM & SJ & TU & PA & PI & $\mathrm{CR}$ & $\mathrm{MO}$ & MA & $\mathrm{FO}$ & $\mathrm{FL}$ & $\mathrm{CB}$ & $\mathrm{CR}$ & $\mathrm{BE}$ & $B A$ & $\mathrm{AR}$ & $\mathrm{AJ}$ & $\mathrm{AQ}$ & $\mathrm{AL}$ \\
\hline & 470 & 1.0 & & & & & 0 & 0.0 & 5.0 & 0.0 & 1.0 & 1.0 & 0.0 & \begin{tabular}{|l|}
0.0 \\
\end{tabular} & 13.0 & 30 & 10 & 1.0 & 1.0 & 0.0 & 1.0 & 8.0 & 10.0 & 0 \\
\hline & & & 0 & 0 & 0 & & & & 3.0 & 0 & 4.0 & 0 & & .0 & 10.0 & .0 & .0 & .0 & 5.0 & 1.0 & 1.0 & 0 & .0 & \\
\hline & & 4 & 1.4 & 4 & 0 & & & 0 & 7.1 & .1 & & 0 & & .4 & 8.6 & & 4 & 9 & 1.4 & 2.9 & 5.7 & & 4.3 & 0 \\
\hline & & 0 & 4.0 & 13.0 & 4.0 & & & 0 & 7.0 & .0 & & 0 & & 1.0 & 11.0 & 0 & 4.0 & 1.0 & 0 & 3.0 & 4.0 & & .0 & 0 \\
\hline & & & 0 & 3.0 & 20.0 & 0 & .0 & 4.0 & 7.0 & .0 & 0 & .0 & & 1.0 & 16.0 & 2.0 & 2.0 & 2.0 & 0 & 4.0 & 2.0 & 6.0 & 3.0 & 0 \\
\hline & & & & 0 & 7 & 23.3 & & 3 & 3.3 & .0 & & 0 & & 0.0 & 13.3 & & & & & & 3.3 & & 6.7 & \\
\hline & & & & 0 & 0 & 67 & 6.7 & 6.7 & 6.7 & .0 & 3.3 & 0 & & 1.0 & 20.0 & 0.0 & 1.0 & .0 & 0.0 & 0.0 & 0.0 & & 0.0 & 7 \\
\hline & & & & 7 & 3 & & & 6.7 & 10.0 & 3.3 & 7 & 7 & 1 & 1.7 & 13.3 & 1.7 & 1.7 & 8.3 & .0 & 0.0 & 3 & & 1.7 & 8.3 \\
\hline & & & & 7 & 8 & & & 0.0 & 19.0 & 2.9 & & 0 & & 0.0 & 14.3 & 4.8 & & & & & 8 & & 4.8 & \\
\hline & & & [ & 5.3 & 0.7 & 0 & & 1.3 & 5.3 & 5.3 & 6.7 & 0.0 & 0.0 & 2.7 & 14.7 & 10.7 & 10.7 & 1.3 & 6.7 & 0.0 & 4.0 & & 10.7 & 0.0 \\
\hline & & & 2 & 2 & 2 & & & 2.4 & 7.2 & 3.2 & 4.4 & .0 & & 1.6 & 17.6 & 4.8 & 5.6 & 8 & & & .6 & & 4.0 & .0 \\
\hline & & & 0 & 3.3 & 6.7 & 0 & ח0 & 0.0 & 0.0 & 0.0 & 0.0 & 0.0 & 0.0 & 0.0 & 33.3 & 0.0 & 0.0 & 20.0 & 0.0 & 0.0 & 0.0 & & 6.7 & 1.0 \\
\hline & & & 0 & \begin{tabular}{|l|}
5.0 \\
\end{tabular} & 10 & & & 0.0 & 5.0 & 0.0 & 10.0 & 0.0 & 15.0 & 0.0 & 7.5 & .0 & .5 & 5.0 & .0 & 5 & 50 & & 0 & 2.5 \\
\hline & & & & 5 & & & & 0.0 & 0.0 & 9.9 & & 0 & & & 13.0 & 6.5 & & & & & & & & 3 \\
\hline & & & & 0 & 4 & & 20 & 2.0 & 4.0 & 2.0 & 8.0 & 0.0 & & 1.0 & 38.5 & 5.0 & 1.0 & 1.5 & 6.0 & 0.0 & 5.5 & & 2.5 & 1.5 \\
\hline & & 3.2 & & 0 & 0 & & & 3.2 & 3.2 & 5.3 & 9.5 & .0 & & 2.1 & 8.4 & 28.4 & 9.5 & 5.3 & 1.1 & 0.0 & 4.2 & & 2 & 5.3 \\
\hline & & & & & & & & 2.0 & 4.0 & 12.0 & & & & & 10.0 & 11.0 & 17.0 & & 5.0 & 3.0 & & & 0 & 0 \\
\hline & & 8.4 & 3.2 & 3.2 & 1.1 & & 11 & 1.1 & 3.2 & 1.1 & 7.4 & 0.0 & 0 & 2.1 & 12.6 & 8.4 & 6.3 & 11.6 & 4.2 & 2.1 & 6.3 & & 6.3 & 5.3 \\
\hline & & & 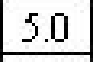 & & & & & 1.0 & 2.0 & 1.0 & 0 & 0.0 & & & 13.0 & & & 6.0 & 34.0 & 0.0 & 0.0 & & 4.0 & 2.0 \\
\hline & & 20 & 2.9 & 86 & 0.0 & & & 0.0 & 2.9 & 20 & 30 & 0.0 & 5.7 & 0.0 & 8.6 & 2.9 & 0.0 & 0.0 & 2.9 & 11.4 & 5.7 & & 2.9 & 5.7 \\
\hline & & 2.0 & 4.0 & 1.0 & 3.0 & 0.0 & & 2.0 & 3.0 & 1.0 & 8.0 & 0.0 & & 0.0 & 16.0 & 4.0 & 6.0 & 9.0 & 7.0 & 0.0 & 16.0 & 7.0 & 1.0 & 4.0 \\
\hline & & 1.0 & 3.0 & 4.0 & 0.0 & 1 & & 0.0 & 2.0 & 1.0 & 1.0 & 0.0 & 2. & 1.0 & 14.0 & 2.0 & 3.0 & 1.0 & 4.0 & 1.0 & 3.0 & 36.0 & 4.0 & 4.0 \\
\hline & & 2.1 & 3.2 & 2.1 & 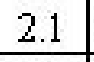 & & & 2.1 & 5.3 & 3.2 & 2.1 & 0.0 & 5.4 & 0.0 & 5.3 & 10.5 & 7.4 & 3.2 & 5.3 & 2.1 & 2.1 & 4.2 & 23.2 & \begin{tabular}{|l|l}
1.1 \\
\end{tabular} \\
\hline $\mathrm{AL}$ & 1.4 & 2.9 & 2.9 & 4.3 & 4.3 & 0.0 & 1.4 & 0.0 & 1.4 & 2.9 & 2.9 & 0.0 & 1.4 & 4.3 & 12.9 & 8.6 & 8.6 & 5.7 & 2.9 & 2.9 & 2.9 & 5.7 & 5.7 & $14 . ?$ \\
\hline
\end{tabular}




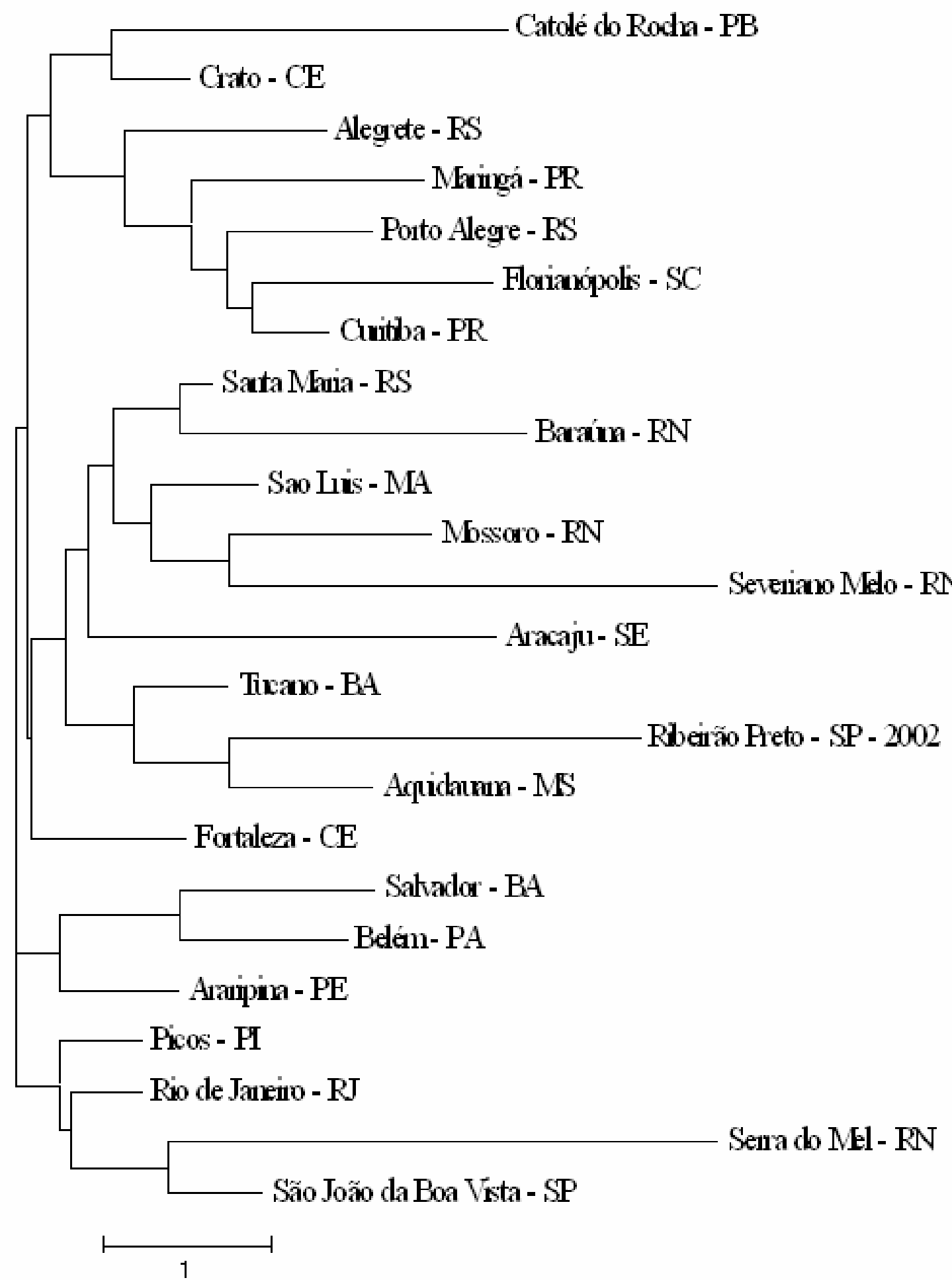

Figura 15: Dendograma de proximidade morfológica entre as populações brasileiras de abelhas africanizadas construído com características de todos os indivíduos na base de dados.

A distribuição gráfica dos centróides dos grupos de acordo com as funções discriminantes (Figura 16) mostra o grupo de Ribeirão Preto - SP 2002 mais distante dos demais, isolado na parte inferior do gráfico. Todas as demais populações ficam distribuídas 
de maneira a não formarem padrões de distribuição. Entretanto, vale lembrar que somente dois eixos estão representados neste gráfico e que as equações de discriminação e identificação sempre criam espaços com $\mathbf{n}-1$ dimensões, sendo que $\mathbf{n}$ corresponde ao número de medidas utilizadas nas análises, no nosso caso, 33 dimensões.

A reconstrução gráfica das formas médias dos marcos anatômicos para as populações de abelhas africanizadas confirma os resultados do gráfico de análises discriminantes, onde a população de Ribeirão Preto - SP é a que mais se diferencia nos perfil morfológico dentre as demais populações (ver exemplo da variação na figura 17). A maior variação da população de Ribeirão Preto para as demais parece se localizar na região dos marcos anatômicos 19 e 6, demonstrando assim a variação dos marcos anatômicos mostrada na figura 17. A figura 18 mostra um exemplo da menor variação encontrada entre as outras populações de abelhas africanizadas. 


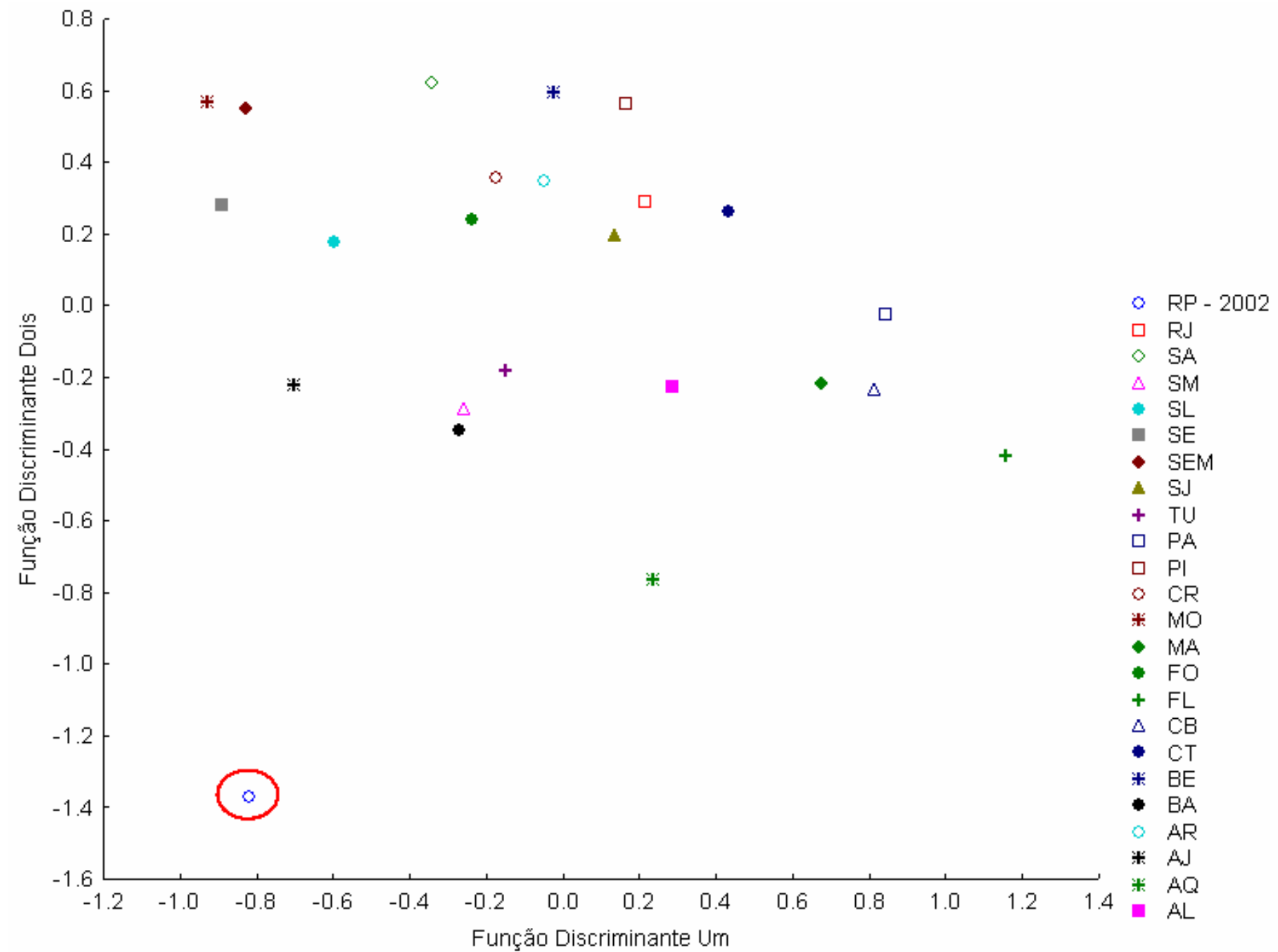

Figura 16: Análise de discriminantes canônicas das populações de abelhas africanizadas estudadas. Destacada com o grande círculo vermelho esta a população de Ribeirão Preto - SP 


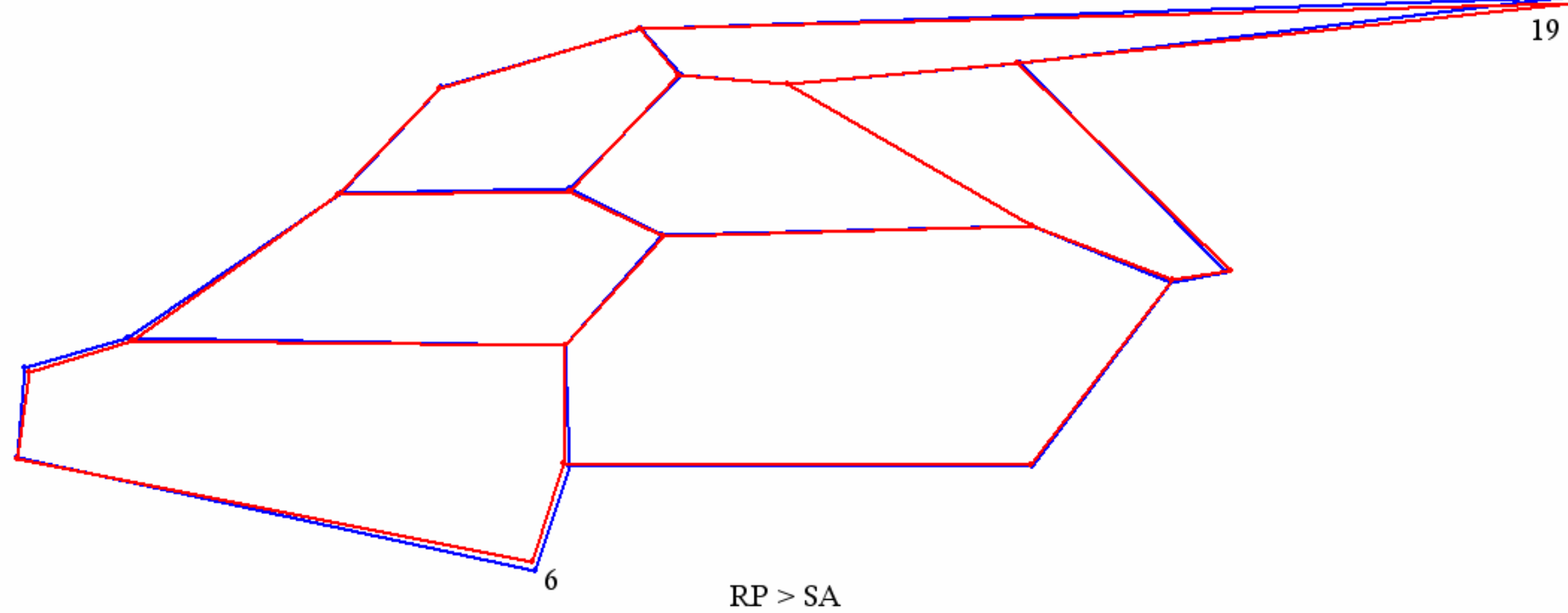

Figura 17: Comparação do deslocamento dos marcos anatômicos na população de abelhas africanizadas de Salvador - BA em comparação com a população de Ribeirão Preto. Na reconstrução, Ribeirão Preto corresponde ao formato em vermelho e a população de Salvador corresponde ao formato em azul. Em destaque, os dois marcos anatômicos com maior deslocamento. 


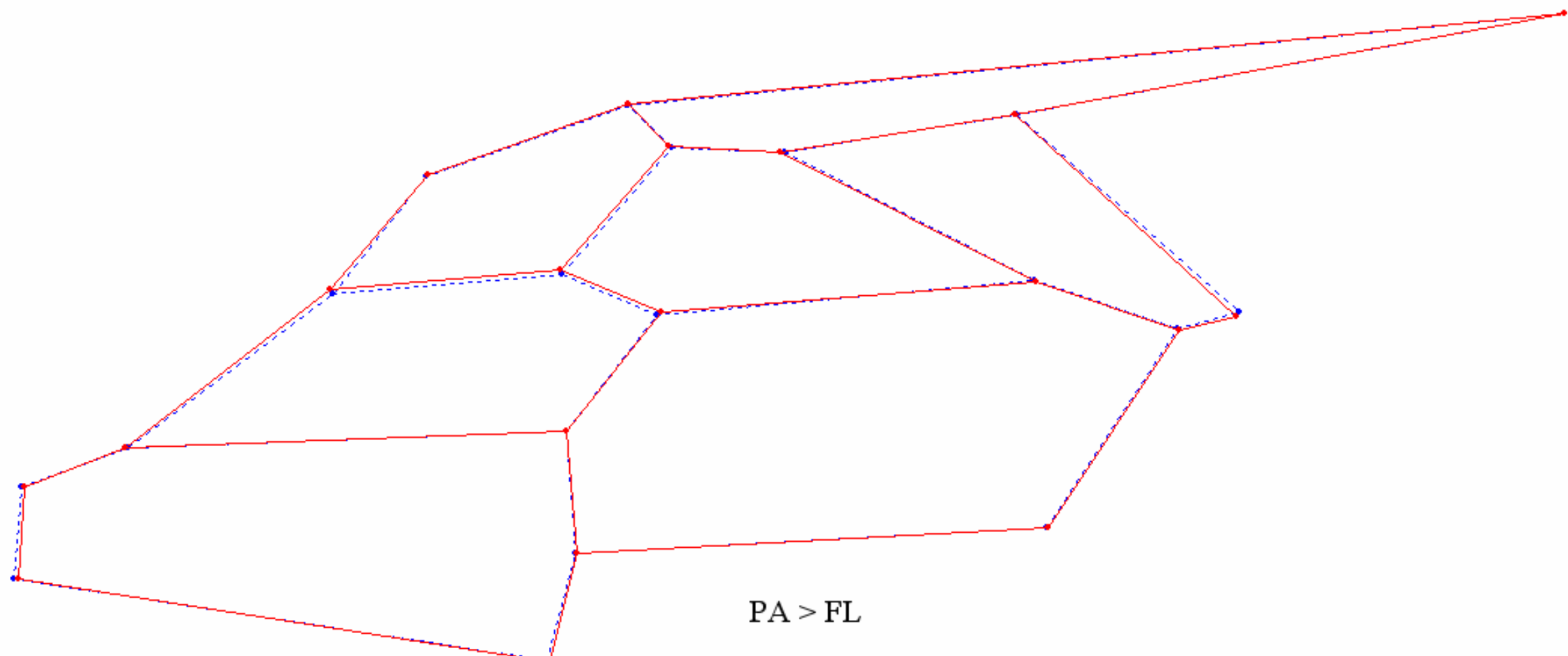

Figura 18: Comparação do deslocamento dos marcos anatômicos nas populações de abelhas africanizadas de Porto Alegre (PA) em comparação com a população de Florianópolis (FL). Na reconstrução, Porto Alegre corresponde ao formato em vermelho e a população de Florianópolis corresponde ao formato em azul. 
A identificação das subespécies e populações de Apis mellifera por morfometria tradicional não leva em consideração os indivíduos, mas sim médias de indivíduos provenientes de uma mesma colônia, e a identificação é feita com base nas colônias como unidade evolutiva. Neste trabalho, a metodologia de análise de deformações relativas foi pela primeira vez testada na discriminação e identificação de subespécies e populações de Apis mellifera, então, as amostras foram avaliadas utilizando-se tanto os indivíduos quanto as médias de indivíduos de uma mesma colônia, permitindo assim a determinação de um protocolo que apresente resultados melhores e mais confiáveis.

Ao utilizarmos as médias dos indivíduos de mesma colônia como parâmetro de análise, encontramos que 33 deformações relativas contribuem significantemente $(\mathrm{P}<0,05)$ para a separação dos grupos (A. m. ligustica, A. m. carnica, A. m. mellifera, A. m. scutellata, Fernando de Noronha e as amostras de populações de abelhas africanizadas).

A MANOVA mostrou diferenças estatisticamente significantes (Wilk's $\lambda=0.0004$; $\mathrm{P}<0.0001)$ entre os grupos. Entretanto, nesta análise, diversos pares de populações não puderam ser estatisticamente diferenciados $(\mathrm{P}>0,05)$ pelas distâncias quadradas de Mahalanobis (Tabela 9). 
Tabela 9: Distâncias quadradas de Mahalanobis avaliando a média de indivíduos de uma mesma colônia entre as populações estudadas (metade superior da tabela) e suas significâncias estatísticas (metade inferior da tabela). Os pontos em destaque indicam os pares de populações nas quais a distância entre os centróides não foi estatisticamente significante $(\alpha=0,05)$.

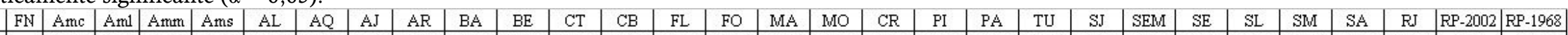

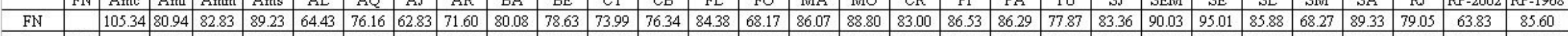

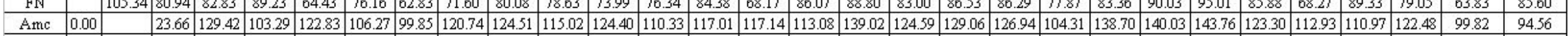

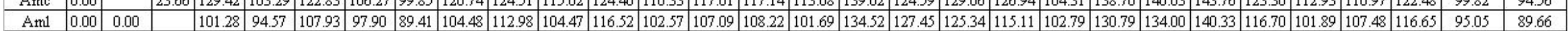

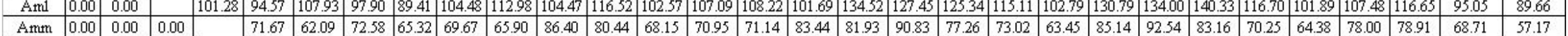

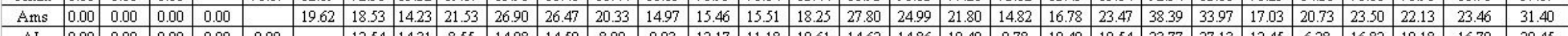

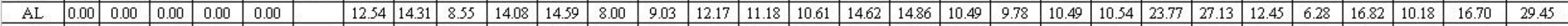
\begin{tabular}{lll|l|l|l|l|l|l|l|l|l|l|l|l|l|l|l|l|l|l|l|l|l|l|l|l|l|l|l|l|l|l|l}
$\mathrm{AQ}$ & 0.00 & 0.00 & 0.00 & 0.00 & 0.00 & 0.00 & & 16.73 & 13.56 & 13.00 & 13.64 & 10.83 & 8.80 & 11.86 & 13.91 & 13.39 & 20.23 & 18.12 & 12.17 & 9.67 & 7.11 & 15.91 & 32.16 & 25.33 & 13.17 & 8.71 & 14.06 & 11.53 & 10.39 & 27.98 \\
\hline
\end{tabular}

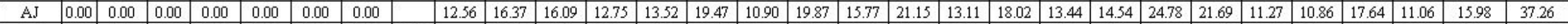

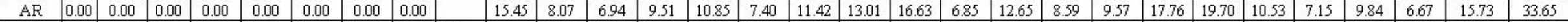

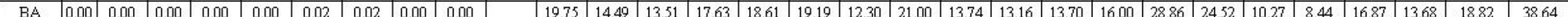

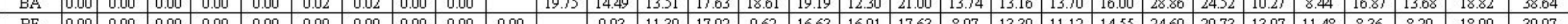

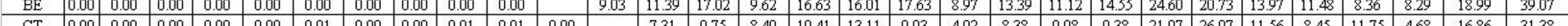

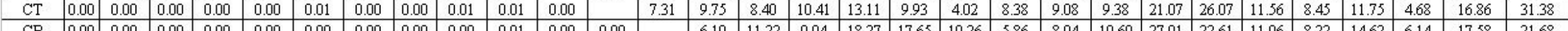

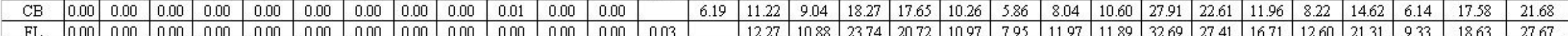

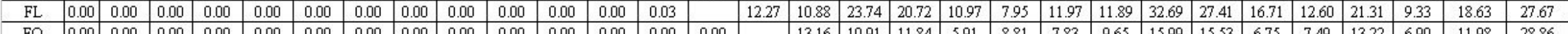

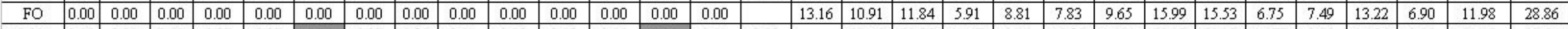

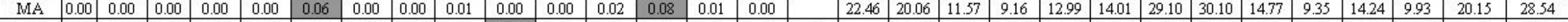

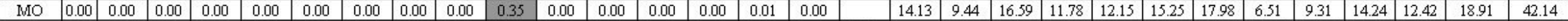

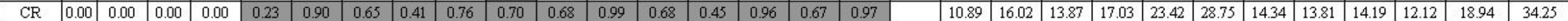

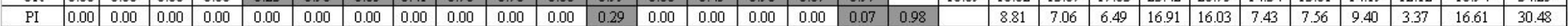

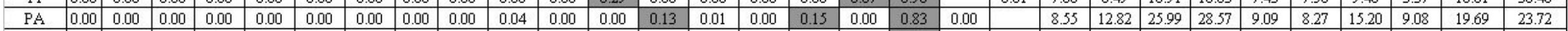

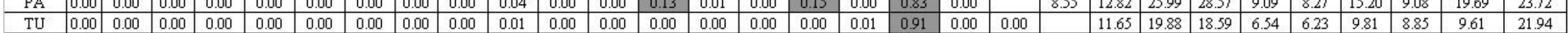

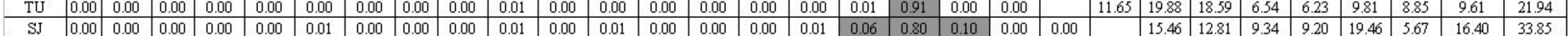

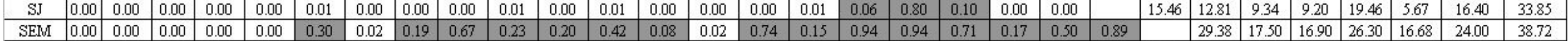

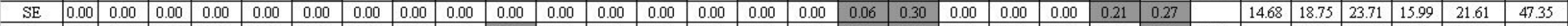

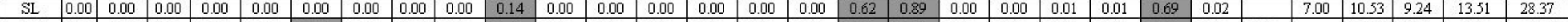

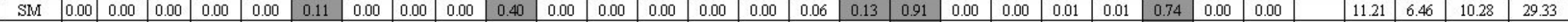

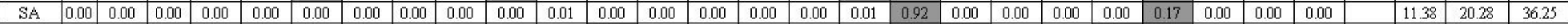

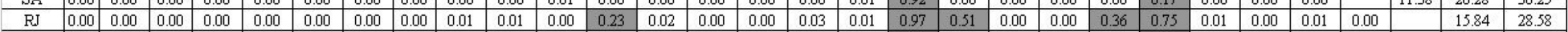

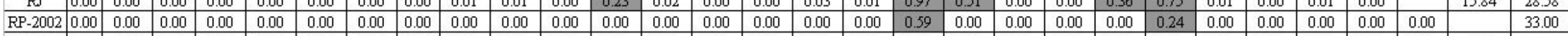

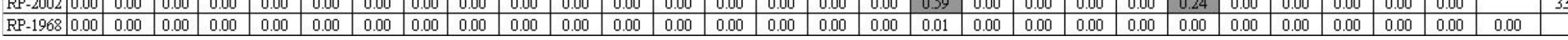


As funções discriminantes lineares foram capazes de distinguir 69,6\% das colônias dentro de seus respectivos grupos (Tabela 10), com $41,1 \%$ de classificações corretas no teste de validação cruzada (Tabela 11). Os grupos das subespécies européias (A. m. ligustica, A. m. carnica, A. m. mellifera) apresentaram $100 \%$ de acerto nas classificações, tanto nas análises discriminantes quanto na validação cruzada. A população de Ribeirão Preto - SP 1968 teve uma taxa de $88 \%$, tanto na classificação quanto na identificação por validação cruzada e A. m. scutellata obteve $78,6 \%$ de acerto na classificação e $57,1 \%$ na identificação por validação cruzada. Entre as populações africanizadas atuais, destaque para Belém - PA (BE), com 95\% de acerto nas análises discriminantes e 70\% na identificação por validação cruzada. Aracaju - SE (AJ), apresentou-se com $75 \%$ de acerto na classificação e $60 \%$ na identificação por validação cruzada. As demais populações que apresentaram altas taxas de acerto nas análises discriminantes não repetiram tal desempenho nos testes de validação cruzada. 
Tabela 10: Classificação de colônias dentro de seus respectivos grupos mediante avaliação de médias de indivíduos de mesma colônia. As linhas representam as classificações esperadas e as colunas as classificações observadas. Em destaque estão os valores em porcentagem de colônias corretamente classificadas dentro de seus grupos.

\begin{tabular}{|c|c|c|c|c|c|c|c|c|c|c|c|c|c|c|c|c|c|c|c|c|c|c|c|c|c|c|c|c|c|c|}
\hline & $\mathrm{FN}$ & Amc & Aml & Amm & Ans & AL & 0 & $\mathrm{AJ}$ & $\mathrm{AB}$ & BA & $\mathrm{BE}$ & CT & $\mathrm{CB}$ & FL & $\mathrm{FO}$ & MA & MO & $\mathrm{CR}$ & PI & PA & $\mathrm{TU}$ & SJ & SEM & SE & SL & SM & SA & RJ & RP-2002 & RP-1968 \\
\hline $\mathrm{FN}$ & 100.0 & 0.0 & 0.0 & 0.0 & 0.0 & 0.0 & 0.0 & 0.0 & 0.0 & 0.0 & 0.0 & 0.0 & 0.0 & 0.0 & 0.0 & 0.0 & 0.0 & 0.0 & 0.0 & 0.0 & 0.0 & 0.0 & 0.0 & 0.0 & 0.0 & 0.0 & 0.0 & 0.0 & 0.0 & 0.0 \\
\hline Amc & 0.0 & 100.0 & 0.0 & 0.0 & 0.0 & 0.0 & 0.0 & 0.0 & 0.0 & 0.0 & 0.0 & 0.0 & 0.0 & 0.0 & 0.0 & 0.0 & 0.0 & 0.0 & 0.0 & 0.0 & 0.0 & 0.0 & 0.0 & 0.0 & 0.0 & \begin{tabular}{|l|l}
0.0 \\
\end{tabular} & 0.0 & 0.0 & 0.0 & 0.0 \\
\hline And & 0.0 & 0.0 & 100.0 & 0.0 & 0.0 & 0.0 & 0.0 & 0.0 & 0.0 & 0.0 & 0.0 & 0.0 & 0.0 & 0.0 & 0.0 & 0.0 & 0.0 & 0.0 & 0.0 & 0.0 & 0.0 & 0.0 & 0.0 & 0.0 & 0.0 & 0.0 & 0.0 & 0.0 & 0.0 & 0.0 \\
\hline Amm & 0.0 & 0.0 & 0.0 & 100.0 & 0.0 & 0.0 & 0.0 & 0.0 & 0.0 & 0.0 & 0.0 & 0.0 & 0.0 & 0.0 & 0.0 & 0.0 & 0.0 & 0.0 & 0.0 & 0.0 & 0.0 & 0.0 & 0.0 & 0.0 & 0.0 & 0.0 & 0.0 & 0.0 & 0. & 0.0 \\
\hline Ams & 0.0 & 0.0 & 0.0 & 0.0 & 78.6 & 0.0 & 0.0 & 0.0 & 0.0 & 0.0 & 0.0 & 0.0 & 7.1 & 7.1 & 0.0 & 0.0 & 0.0 & 0.0 & 0.0 & 0.0 & 7.1 & 0.0 & 0.0 & 0.0 & 0.0 & 0.0 & 0.0 & 0.0 & & 0.0 \\
\hline $\mathrm{AL}$ & 0.0 & 0.0 & 0.0 & 0.0 & 0.0 & 57.1 & 0.0 & 0.0 & 0.0 & 0.0 & 0.0 & 7.1 & 0.0 & 0.0 & 7.1 & 7.1 & 0.0 & 0.0 & 0.0 & 7.1 & 0.0 & 7.1 & 00 & 0.0 & 0.0 & 0.0 & 7.1 & 0.0 & 0.0 & 0.0 \\
\hline $\mathrm{AQ}$ & 0.0 & 0.0 & 0.0 & 0.0 & 0.0 & 0.0 & 73.7 & 0.0 & 0.0 & 5.3 & 5.3 & 0.0 & 0.0 & 0.0 & 0.0 & 0.0 & 0.0 & 0.0 & 0.0 & 0.0 & 5.3 & 0.0 & 0.0 & 0.0 & 0.0 & 0.0 & 0.0 & 0.0 & 10.5 & 0.0 \\
\hline $\mathrm{AJ}$ & 0.0 & 0.0 & 0.0 & 0.0 & 0.0 & 10.0 & 0.0 & 75.0 & 0.0 & 0.0 & 0.0 & 5.0 & 0.0 & 0.0 & 0.0 & 0.0 & 0.0 & 0.0 & 0.0 & 0.0 & 0.0 & 0.0 & 0.0 & 0.0 & 0.0 & 10.0 & 0.0 & 0.0 & & 0.0 \\
\hline $\mathrm{AR}$ & 0 & 0. & 0 & 0.0 & 0.0 & 10.0 & 0.0 & 0.0 & 50.0 & 0.0 & 10.0 & 5.0 & 5.0 & 5.0 & 0.0 & 0.0 & 0.0 & 0.0 & 10.0 & 0.0 & 0.0 & 0.0 & & 0.0 & 5.0 & 0.0 & 0.0 & 0.0 & & \\
\hline $\mathrm{BA}$ & 0.0 & 0.0 & 0.0 & 0.0 & 0.0 & 0.0 & 0.0 & 0.0 & 0.0 & 71.4 & 0.0 & 0.0 & 0.0 & 0.0 & 0.0 & 0.0 & 0.0 & 0.0 & 0.0 & 0.0 & 0.0 & 0.0 & 0.0 & 0.0 & 0.0 & 28.6 & \begin{tabular}{|l|l} 
\\
\end{tabular} & 0.0 & & 0.0 \\
\hline $\mathrm{BE}$ & 0.0 & 0.0 & 0.0 & 0.0 & 0.0 & 0.0 & \begin{tabular}{|l|l} 
\\
\end{tabular} & 0.0 & \begin{tabular}{|l|l} 
\\
\end{tabular} & 0.0 & 95.0 & 0.0 & \begin{tabular}{|l|l} 
\\
\end{tabular} & 0.0 & \begin{tabular}{|l}
0.0 \\
\end{tabular} & 0.0 & 0.0 & 0.0 & 0.0 & 0.0 & 0.0 & \begin{tabular}{|l|l}
0.0 \\
\end{tabular} & 0.0 & 0.0 & 0.0 & \begin{tabular}{|l|l}
0.0 \\
\end{tabular} & \begin{tabular}{|l|l} 
\\
\end{tabular} & 5.0 & J. & 0.0 \\
\hline $\mathrm{CT}$ & 0.0 & 0.0 & 0.0 & 0.0 & 0.0 & 0.0 & 0.0 & 0.0 & \begin{tabular}{|l}
5.3 \\
\end{tabular} & 0.0 & \begin{tabular}{|l|l}
0.0 \\
\end{tabular} & 63.2 & \begin{tabular}{|l|l} 
\\
\end{tabular} & 0.0 & \begin{tabular}{|l|l}
5.3 \\
\end{tabular} & 5.3 & 0.0 & 0.0 & 10.5 & 0.0 & 0.0 & \begin{tabular}{|l|l}
0.0 \\
\end{tabular} & 0.0 & 0.0 & 0.0 & 0.0 & 0.0 & 10.5 & U. & 0.0 \\
\hline CB & 0. & 0.0 & 0. & 0.0 & 0.0 & 5.0 & \begin{tabular}{|l|l}
0.0 \\
\end{tabular} & 5.0 & \begin{tabular}{|l|l} 
\\
\end{tabular} & 5.0 & 0.0 & 5.0 & 65.0 & 0.0 & 5.0 & 0.0 & 0.0 & 0.0 & 5.0 & 0.0 & 0.0 & 0.0 & 0.0 & 0.0 & 0.0 & 0.0 & 0.0 & 5.0 & & 0.0 \\
\hline $\mathrm{FL}$ & 0.0 & 0.0 & 0.0 & 0.0 & 5.3 & 0.0 & \begin{tabular}{|l|l}
0.0 \\
\end{tabular} & 0.0 & \begin{tabular}{|l|l} 
\\
\end{tabular} & 0.0 & 0.0 & 0.0 & 0.0 & 84.2 & 0.0 & 5.3 & 0.0 & 0.0 & 5.3 & 0.0 & 0.0 & 0.0 & 0.0 & 0.0 & 0.0 & 0.0 & 0.0 & 0.0 & & \\
\hline $\mathrm{FO}$ & 0.0 & 0.0 & 0.0 & 0.0 & 2.5 & 0.0 & 0.0 & 0.0 & 2.5 & 0.0 & 5.0 & 0.0 & 2.5 & 5.0 & 65.0 & 0.0 & 0.0 & 0.0 & 7.5 & 0.0 & 0.0 & 2.5 & 0.0 & 2.5 & 0.0 & 2.5 & 0.0 & 0.0 & & 0.0 \\
\hline MA & 0. & 0.0 & 0.0 & 0.0 & 0.0 & 0.0 & 0.0 & 0.0 & 0.0 & 0.0 & 0.0 & 0.0 & 22.2 & 0.0 & 11.1 & 55.6 & 0.0 & 0.0 & 11.1 & 0.0 & 0.0 & 0.0 & 0.0 & 0.0 & 0.0 & 0.0 & 0.0 & 0.0 & U. & 0.0 \\
\hline MO & 0. & 0.0 & 0. & 0.0 & 0.0 & 0.0 & 0.0 & 0.0 & 0.0 & 0.0 & 0.0 & 0.0 & 0.0 & 0.0 & 0.0 & 0.0 & 75.0 & 0.0 & \begin{tabular}{|l|l|}
0.0 \\
\end{tabular} & 0.0 & 0.0 & 0.0 & 0.0 & 0.0 & 0.0 & 25.0 & 0.0 & 0.0 & & 0. \\
\hline $\mathrm{CR}$ & 0.0 & 0.0 & 0.0 & 0.0 & 0.0 & 0.0 & \begin{tabular}{|l|l} 
\\
\end{tabular} & 0.0 & \begin{tabular}{|l|l} 
\\
\end{tabular} & 0.0 & 0.0 & 0.0 & 0.0 & 0.0 & $\mid 0.0$ & 0.0 & 0.0 & 100.0 & 0.0 & 0.0 & 0.0 & 0.0 & 0.0 & 0.0 & 0.0 & 0.0 & 0.0 & 0.0 & & \\
\hline PI & 0. & 0.0 & 0.0 & 0.0 & 0.0 & 0.0 & \begin{tabular}{|l|l}
0.0 \\
\end{tabular} & 0.0 & \begin{tabular}{|l|l} 
\\
\end{tabular} & 0.0 & 0.0 & 4.0 & 4.0 & 0.0 & 8.0 & 0.0 & 0.0 & 0.0 & 72.0 & 0.0 & 4.0 & 0.0 & 0.0 & 0.0 & 0.0 & 0.0 & 0.0 & 8.0 & & 0.0 \\
\hline PA & 0. & 0.0 & 0.0 & 0.0 & 0.0 & 0.0 & 6.7 & 0.0 & 0.0 & 6.7 & 0.0 & 0.0 & 6.7 & 0.0 & 6.7 & 0.0 & 0.0 & 0.0 & \begin{tabular}{|l|}
0.0 \\
\end{tabular} & 66.7 & 0.0 & 0.0 & 0.0 & 0.0 & 6.7 & 0.0 & 0.0 & 0.0 & U. & 0.0 \\
\hline TU & 0.0 & 0.0 & 0.0 & 0.0 & 0.0 & 4.8 & \begin{tabular}{|l|l}
0.0 \\
\end{tabular} & 0.0 & \begin{tabular}{|l}
4.8 \\
\end{tabular} & 0.0 & 0.0 & 0.0 & 0.0 & 0.0 & 4.8 & 0.0 & 0.0 & 0.0 & 9.5 & 0.0 & 61.9 & 0.0 & 0.0 & 0.0 & 0.0 & 0.0 & 4.8 & 0.0 & 9. & 0.0 \\
\hline SJ & 0.0 & 0.0 & 0.0 & 0.0 & 0.0 & 0.0 & 0.0 & 0.0 & \begin{tabular}{|l|l}
8.3 \\
\end{tabular} & 0.0 & \begin{tabular}{|l|l} 
\\
\end{tabular} & 0.0 & 0.0 & 0.0 & 8.3 & 0.0 & 0.0 & 0.0 & 8.3 & 0.0 & \begin{tabular}{|l|}
8.3 \\
\end{tabular} & 66.7 & 0.0 & 0.0 & 0.0 & 0.0 & 0.0 & 0.0 & & \\
\hline SEM & 0. & 0.0 & 0.0 & 0.0 & 0.0 & 0.0 & 0.0 & 0.0 & 0.0 & 0.0 & 0.0 & 0.0 & 0.0 & 0.0 & 0.0 & 0.0 & 0.0 & 0.0 & 0.0 & 0.0 & 0.0 & \begin{tabular}{|l|l}
0.0 \\
\end{tabular} & 100. & 0.0 & 0.0 & 0.0 & 0.0 & 0.0 & & \\
\hline SE & 0.0 & 0.0 & 0.0 & 0.0 & 0.0 & 0.0 & 0.0 & 0.0 & 0.0 & 0.0 & 0.0 & 0.0 & 0.0 & 0.0 & 0.0 & 0.0 & 0.0 & 0.0 & 0.0 & 0.0 & \begin{tabular}{|l|}
0.0 \\
\end{tabular} & $\mid 0.0$ & 0.0 & 100.0 & 0.0 & 0.0 & 0.0 & 0.0 & 0. & 0.0 \\
\hline SL & 0.0 & 0.0 & 0.0 & 0.0 & 0.0 & 0.0 & 5.0 & 0.0 & 5.0 & 5.0 & 0.0 & 0.0 & \begin{tabular}{|l|l}
5.0 \\
\end{tabular} & 0.0 & 5.0 & 0.0 & 5.0 & 0.0 & 0.0 & 5.0 & 0.0 & $\mid 0.0$ & 0.0 & 0.0 & 60.0 & 0.0 & 0.0 & 0.0 & 3.0 & 0.0 \\
\hline SM & 0.0 & 0.0 & 0.0 & 0.0 & 0.0 & 0.0 & 5.0 & 0.0 & \begin{tabular}{|l|l} 
\\
\end{tabular} & 0.0 & \begin{tabular}{|l|l} 
\\
\end{tabular} & 0.0 & 0.0 & 0.0 & 5.0 & 0.0 & 0.0 & 0.0 & \begin{tabular}{|l|l|} 
\\
\end{tabular} & 5.0 & 5.0 & 5.0 & 0. & 0.0 & 0.0 & 60.0 & 0.0 & 10.0 & & \\
\hline SA & 0 & 0. & 0 & 0. & 0.0 & 0.0 & 0.0 & 0 & \begin{tabular}{|l|l} 
\\
\end{tabular} & 0 & \begin{tabular}{|l|l} 
\\
\end{tabular} & 0.0 & 0.0 & 0.0 & 14.3 & & 7.1 & 0.0 & \begin{tabular}{|l|l|}
0.0 \\
\end{tabular} & 0.0 & \begin{tabular}{|l|}
7.1 \\
\end{tabular} & & & & 0.0 & 0.0 & 71.4 & 0.0 & & \\
\hline $\mathrm{RJ}$ & 0.0 & 0.0 & 0.0 & 0.0 & 0.0 & 0.0 & \begin{tabular}{|l|l} 
\\
\end{tabular} & 0.0 & 10.0 & 5.0 & 5.0 & 5.0 & 5.0 & 0.0 & 5.0 & 0.0 & 0.0 & 0.0 & 15.0 & 0.0 & 0.0 & \begin{tabular}{|l|l} 
\\
\end{tabular} & 0.0 & 0.0 & 5.0 & \begin{tabular}{|l|l}
0.0 \\
\end{tabular} & \begin{tabular}{|l|l} 
\\
\end{tabular} & 45.0 & 0.0 & 0.0 \\
\hline P-2002 & 0.0 & 0.0 & 5.6 & 0.0 & 0.0 & 0.0 & \begin{tabular}{|l|l} 
\\
\end{tabular} & 5.6 & 0.0 & 0.0 & 0.0 & 0.0 & 0.0 & 0.0 & 11.1 & 0.0 & 0.0 & 0.0 & 0.0 & 0.0 & 5.6 & 0.0 & 0.0 & 0.0 & 0.0 & 0.0 & 0.0 & 0.0 & 72.2 & 0.0 \\
\hline$P-1968$ & 0.0 & 0.0 & 0.0 & 0.0 & 0.0 & 0.0 & \begin{tabular}{|l|l|}
0.0 \\
\end{tabular} & 0.0 & $\mid 0.0$ & 0.0 & 0.0 & 0.0 & 8.0 & 0.0 & 0.0 & 0.0 & 0.0 & 0.0 & 0.0 & 0.0 & 4.0 & 0.0 & 0.0 & 0.0 & 0.0 & 0.0 & 0.0 & 0.0 & 0.0 & 88.0 \\
\hline
\end{tabular}


Tabela 11: Identificação de colônias por validação cruzada dentro de seus respectivos grupos mediante avaliação de médias de indivíduos de mesma colônia. As linhas representam as classificações esperadas e as colunas as classificações observadas. Em destaque estão os valores em porcentagem de colônias corretamente classificadas dentro de seus grupos.

\begin{tabular}{|c|c|c|c|c|c|c|c|c|c|c|c|c|c|c|c|c|c|c|c|c|c|c|c|c|c|c|c|c|c|c|}
\hline & FN & Amc & Aml & Amm & Ams & AL & $\mathrm{AQ}$ & $\mathrm{A} \mathrm{J}$ & $\mathrm{AR}$ & BA & $\mathrm{BE}$ & $\mathrm{CT}$ & CB & $\mathrm{FL}$ & FO & MA & Mo & $\mathrm{CR}$ & PI & PA & TU & SJ & SEM & SE & SL & SM & SA & RI & RP-2002 & $P-196$ \\
\hline FN & 100.0 & 0.0 & 0.0 & 0.0 & 0.0 & 0.0 & 0.0 & 0.0 & 0.0 & 0.0 & 0.0 & \begin{tabular}{|l|}
0.0 \\
\end{tabular} & 0.0 & 0.0 & 0.0 & 0.0 & \begin{tabular}{|l|}
0.0 \\
\end{tabular} & \begin{tabular}{|l|}
0.0 \\
\end{tabular} & 0.0 & 0.0 & 0.0 & 0.0 & 0.0 & 0.0 & 0.0 & \begin{tabular}{|l|}
0.0 \\
\end{tabular} & 0.0 & 0.0 & 0.0 & 0.0 \\
\hline Amc & 0.0 & 100.0 & 0.0 & 0.0 & 0.0 & 0.0 & 0.0 & 0.0 & 0.0 & 0.0 & 0.0 & 0.0 & 0.0 & 0.0 & 0.0 & 0.0 & \begin{tabular}{|l|}
0.0 \\
\end{tabular} & 0.0 & 0.0 & 0.0 & 0.0 & 0.0 & 0.0 & 0.0 & 0.0 & 0.0 & 0.0 & 0.0 & 00 & 0.0 \\
\hline Aml & 0.0 & 0.0 & 100.0 & 0.0 & 0.0 & 0.0 & 0.0 & 0.0 & 1.0 & 0.0 & 0.0 & 0.0 & 0.0 & 0.0 & 0.0 & 0.0 & 0.0 & 0.0 & 0.0 & 0.0 & 0.0 & 0.0 & 0.0 & 0.0 & 0.0 & 0.0 & 0.0 & 0.0 & & 0.0 \\
\hline Amm & 0.0 & 0.0 & 0.0 & 100.0 & 0 & 0.0 & & 0.0 & 10 & 0.0 & 0.0 & 0.0 & 0.0 & 0.0 & 0.0 & 0.0 & 0.0 & \begin{tabular}{|l|}
0.0 \\
\end{tabular} & 0.0 & 0.0 & 0.0 & 0.0 & 1.0 & 0.0 & 0.0 & 0.0 & 0.0 & 0.0 & & 0.0 \\
\hline Ams & 0.0 & 0.0 & 0 & 0.0 & 57.1 & 7.1 & 0.0 & 14.3 & 0.0 & 0.0 & 0.0 & 0.0 & 7.1 & 7.1 & 0.0 & 0.0 & 0.0 & 0.0 & 0.0 & 0.0 & 7.1 & 00 & 0.0 & 0.0 & 0.0 & 0.0 & 0.0 & & & \\
\hline $\mathrm{AL}$ & 0.0 & 0.0 & U & 0.0 & 0.0 & 21.4 & 0.0 & 0.0 & 0.0 & 0.0 & 0.0 & 14.3 & 7.1 & 0.0 & 14.3 & 7.1 & 7.1 & 0.0 & 0.0 & 7.1 & 0.0 & 7.1 & 0.0 & 0.0 & 0.0 & 7.1 & 7.1 & III & & 0.0 \\
\hline $\mathrm{AQ}$ & 0.0 & 0.0 & 0.0 & 0.0 & 0.0 & 0.0 & 21.1 & 0.0 & 5.3 & 5.3 & 10.5 & 5.3 & 5.3 & 0.0 & 0.0 & 0.0 & \begin{tabular}{|l|l|}
0.0 \\
\end{tabular} & 0.0 & 0.0 & 5.3 & 15.8 & 0.0 & 0.0 & 0.0 & 0.0 & 10.5 & 0.0 & 0 & 13 & 0.0 \\
\hline AJ & 0.0 & 0.0 & 0.0 & 0.0 & 0. & 10.0 & 5.0 & 60.0 & 0.0 & 0.0 & 0.0 & 5.0 & 0.0 & 0.0 & 0.0 & 0.0 & 0.0 & 0.0 & 0.0 & 0.0 & 0.0 & 0.0 & 0.0 & 0.0 & 5.0 & 10.0 & 0.0 & 0.0 & & J. \\
\hline $\mathrm{AR}$ & 0. & 0.0 & & 0.0 & & 10.0 & 0.0 & 0.0 & 25.0 & 0.0 & 15.0 & 5.0 & 5.0 & 5.0 & 0.0 & 0.0 & \begin{tabular}{|l|}
0.0 \\
\end{tabular} & 0.0 & 15.0 & 0.0 & 5.0 & 0.0 & 0.0 & 0.0 & 5.0 & 0.0 & 5.0 & & & \\
\hline $\mathrm{BA}$ & & 0 & & 0.0 & & 14.3 & & 0.0 & 0.0 & 14.3 & 0.0 & 0.0 & 14.3 & 0.0 & 0.0 & 0.0 & 0.0 & 0.0 & 14.3 & 0.0 & 0.0 & 1.0 & 1.0 & 0.0 & 14.3 & 28.6 & 0.0 & & & \\
\hline $\mathrm{BE}$ & 0.0 & 0.0 & 0 & 0.0 & 0 & 0.0 & 0.0 & 0.0 & 5.0 & 0.0 & 70.0 & \begin{tabular}{|l|}
5.0 \\
\end{tabular} & 0.0 & 0.0 & 5.0 & 0.0 & 0.0 & 0.0 & \begin{tabular}{|l|}
0.0 \\
\end{tabular} & 5.0 & 0.0 & \begin{tabular}{|l|l} 
\\
\end{tabular} & 0.0 & 5.0 & 0.0 & 0.0 & 0.0 & & & \\
\hline CT & 0.0 & 0.0 & 0.0 & 0.0 & & 5.3 & 0.0 & 0.0 & 15.8 & 0.0 & 0.0 & 10.5 & 5.3 & 10.5 & 5.3 & 5.3 & 0.0 & 0.0 & 21.1 & \begin{tabular}{|l}
5.3 \\
\end{tabular} & 0.0 & 0.0 & 0.0 & 0.0 & 0.0 & 0.0 & \begin{tabular}{|l}
5.3 \\
\end{tabular} & 0.2 & & \\
\hline $\mathrm{CB}$ & 0.0 & 0.0 & 0.0 & 0.0 & 5. & 5.0 & 0.0 & 10.0 & 0.0 & 5.0 & \begin{tabular}{|l|}
0.0 \\
\end{tabular} & 10.0 & 25.0 & 10.0 & 5.0 & 0.0 & \begin{tabular}{|l|l|}
0.0 \\
\end{tabular} & \begin{tabular}{|l|}
0.0 \\
\end{tabular} & 5.0 & 10.0 & 0.0 & 0.0 & 0.0 & 0.0 & 0.0 & 0.0 & \begin{tabular}{|l}
0.0 \\
\end{tabular} & 10.0 & & J. \\
\hline FL & 0.0 & 0. & 0.1 & 0.0 & 10. & 5.3 & 5.3 & 0.0 & 0.0 & 0.0 & 0.0 & \begin{tabular}{|l|}
5.3 \\
\end{tabular} & 5.3 & \begin{tabular}{|l|l|}
42.1 \\
\end{tabular} & 0.0 & 10.5 & 0.0 & 0.0 & \begin{tabular}{|l|}
10.5 \\
\end{tabular} & 0.0 & 0.0 & 0.0 & 0.0 & 0.0 & 0.0 & 0.0 & 0.0 & 2. & & \\
\hline FO & 0. & 0.0 & 0 & 0.0 & & 0.0 & 0.0 & 0.0 & 7.5 & $\mid 0.0$ & \begin{tabular}{|l|} 
\\
\end{tabular} & 0.0 & 2.5 & 5.0 & 47.5 & 0.0 & 0.0 & 0.0 & 7.5 & 0.0 & 2.5 & 3.0 & 2.5 & 2.5 & 2.5 & 5.0 & 0.0 & & & \\
\hline MA & 0.0 & 0.0 & & 0.0 & 0 & 0.0 & 0.0 & 0.0 & 11.1 & 0.0 & 0.0 & 0.0 & 22.2 & \begin{tabular}{|l|l|}
0.0 \\
\end{tabular} & 11.1 & 44.4 & 0.0 & 0.0 & 11.1 & 0.0 & 0.0 & 0.0 & & 0.0 & 10 & \begin{tabular}{|l|}
0.0 \\
\end{tabular} & 0.0 & & & \\
\hline MO & 0.0 & 0.0 & 0. & 0.0 & & 0.0 & 0.0 & 0.0 & 0.0 & $\mid 0.0$ & 0.0 & $\mid 0.0$ & \begin{tabular}{|l|l|}
0.0 \\
\end{tabular} & 0.0 & 0.0 & 0.0 & 25.0 & 0.0 & 12.5 & 0.0 & 0.0 & 0.0 & 0.0 & 0.0 & 25.0 & 25.0 & 12.5 & & & \\
\hline $\mathrm{CR}$ & 0.0 & 0.0 & 0. & 0.0 & 0. & 0.0 & 0.0 & 0.0 & 0.0 & 0.0 & \begin{tabular}{|l|l|} 
\\
\end{tabular} & 33.3 & 0.0 & 0.0 & 0.0 & \begin{tabular}{|l|l}
0.0 \\
\end{tabular} & \begin{tabular}{|l|l|}
0.0 \\
\end{tabular} & 0.0 & 33.3 & 0.0 & 0.0 & 0.0 & 0.0 & 0.0 & 0.0 & 0.0 & 0.0 & 0.0 & 33 & \\
\hline PI & 0. & 0.0 & 0. & 0.0 & & 0.0 & 0.0 & 0.0 & 0.0 & 0.0 & 0.0 & 12.0 & 4.0 & \begin{tabular}{|l|l|}
0.0 \\
\end{tabular} & 24.0 & 0.0 & \begin{tabular}{|l|}
0.0 \\
\end{tabular} & 0.0 & 24.0 & 0.0 & 8.0 & 4.0 & 0.0 & 0.0 & \begin{tabular}{|l|l}
0.0 \\
\end{tabular} & 8.0 & 4.0 & 12. & & \\
\hline PA & 0.0 & 0.0 & 0.0 & 0.0 & 0.0 & 0.0 & 6.7 & 0.0 & 0.0 & \begin{tabular}{|l}
6.7 \\
\end{tabular} & 0.0 & 6.7 & 20.0 & 67 & 13.3 & 0.0 & \begin{tabular}{|l|}
0.0 \\
\end{tabular} & \begin{tabular}{|l|}
0.0 \\
\end{tabular} & 0.0 & 13.3 & 13.3 & 0.0 & 0.0 & \begin{tabular}{|l|}
0.0 \\
\end{tabular} & 6.7 & 6.7 & 0.0 & 0.0 & & 0.4 \\
\hline TU & 0.0 & 0.0 & 0. & 0.0 & 0 & 4.8 & 9.5 & 0.0 & 4.8 & \begin{tabular}{|l|l}
0.0 \\
\end{tabular} & 0.0 & 4.8 & \begin{tabular}{|l|l|}
0.0 \\
\end{tabular} & 9.5 & 9.5 & 0.0 & 0.0 & 0.0 & 9.5 & \begin{tabular}{|l|l|}
0.0 \\
\end{tabular} & 33.3 & \begin{tabular}{|l|l} 
\\
\end{tabular} & 0.0 & 0.0 & 0.0 & \begin{tabular}{|l|}
0.0 \\
\end{tabular} & 4.8 & 0.0 & & \\
\hline SJ & 0 & 0. & 0 & 0.0 & & 16.7 & 0.0 & 0.0 & \begin{tabular}{|l|}
8.3 \\
\end{tabular} & \begin{tabular}{|l|l}
0.0 \\
\end{tabular} & \begin{tabular}{|l}
0.0 \\
\end{tabular} & \begin{tabular}{|l|}
0.0 \\
\end{tabular} & 0.0 & \begin{tabular}{|l|}
8.3 \\
\end{tabular} & 8.3 & 0.0 & \begin{tabular}{|l|}
0.0 \\
\end{tabular} & 0.0 & 16.7 & 0.0 & 8.3 & 8.3 & 0.0 & 8.3 & 0. & 0.0 & 0.0 & & & \\
\hline SEM & 0.0 & 0. & 0. & 0.0 & & 0.0 & 0.0 & 0.0 & 0.0 & 0.0 & 0.0 & \begin{tabular}{|l|}
0.0 \\
\end{tabular} & 0.0 & 0.0 & 33.3 & 0.0 & 33.3 & 0.0 & \begin{tabular}{|l|l|}
0.0 \\
\end{tabular} & 0.0 & 0.0 & 33.3 & 0.0 & 0.0 & 0.0 & 0.0 & 0.0 & 0.0 & & \\
\hline SE & 0.0 & 0.0 & 0 & 0. & 0 & 0.0 & 0.0 & 0.0 & 0.0 & 0.0 & 0.0 & 0.0 & 0.0 & 0.0 & 16.7 & 0.0 & \begin{tabular}{|l|}
0.0 \\
\end{tabular} & 0.0 & 0.0 & 0.0 & 0.0 & 50.0 & 0.0 & 0.0 & 16.7 & 0.0 & 0.0 & 16.7 & & \\
\hline $\mathrm{SL}$ & 0.0 & 0.0 & 0. & 0.0 & 5.0 & 0.0 & 5.0 & 5.0 & 5.0 & 5.0 & 0.0 & 0.0 & 5.0 & 0.0 & 15.0 & 0.0 & \begin{tabular}{|l|l|}
5.0 \\
\end{tabular} & 0.0 & 0.0 & \begin{tabular}{|l|l|}
5.0 \\
\end{tabular} & 15.0 & 0.0 & 0.0 & 0.0 & 20.0 & 5.0 & 0.0 & 0.0 & 5 & 0.0 \\
\hline SM & 0.0 & 0.0 & 0. & 0.0 & 0.0 & 5.0 & 5.0 & 0.0 & 0.0 & 0.0 & 0.0 & 0.0 & 0.0 & \begin{tabular}{|l|}
0.0 \\
\end{tabular} & 15.0 & 0.0 & 10.0 & 0.0 & 5.0 & 5.0 & 5.0 & 5.0 & 0.0 & 0.0 & 0.0 & 35.0 & 0.0 & 10.0 & & \\
\hline SA & 0. & 0.0 & 0. & 0.0 & 0 & 0.0 & 7. & 0.0 & 0.0 & 7.1 & \begin{tabular}{|l|}
7.1 \\
\end{tabular} & 0.0 & \begin{tabular}{|l|l} 
\\
\end{tabular} & 0.0 & 14.3 & 7.1 & 7.1 & 0.0 & 7.1 & 0.0 & 7.1 & 0.0 & 0.0 & 0.0 & 0. & 0.0 & 35.7 & 0.0 & & \\
\hline $\mathrm{RJ}$ & 0 & 0. & 0 & 0 & & 0.0 & 0.0 & 0.0 & 10.0 & 5.0 & \begin{tabular}{|l|}
5.0 \\
\end{tabular} & 15.0 & 5.0 & 0 & 10.0 & 0.0 & 0.0 & 0.0 & 10.0 & & 0.0 & 10.0 & & 0.0 & & 5.0 & 0 & & & \\
\hline-2002 & 0.0 & 0.0 & 5.6 & 0.0 & 0.0 & 0.0 & 11.1 & 5.6 & 5.6 & \begin{tabular}{|l|l} 
\\
\end{tabular} & \begin{tabular}{|l|}
0.0 \\
\end{tabular} & 0.0 & \begin{tabular}{|l|l}
0.0 \\
\end{tabular} & 0.0 & $\mid 11.1$ & 0.0 & 0.0 & \begin{tabular}{|l|}
0.0 \\
\end{tabular} & \begin{tabular}{|l|l|}
0.0 \\
\end{tabular} & 0.0 & 5.6 & 0.0 & 0.0 & 0.0 & 5.6 & 5.6 & \begin{tabular}{|l}
0.0 \\
\end{tabular} & 0.0 & 44.4 & 0.0 \\
\hline $2-1908$ & 0.0 & 0.0 & 0.0 & 0.0 & 0.0 & 0.0 & 0.0 & 0.0 & \begin{tabular}{|l|}
0.0 \\
\end{tabular} & 0.0 & 0.0 & \begin{tabular}{|l|}
0.0 \\
\end{tabular} & 8.0 & 0.0 & $\mid 0.0$ & 0.0 & 0.0 & 0.0 & \begin{tabular}{|l|}
0.0 \\
\end{tabular} & 0.0 & 4.0 & $\mid 0.0$ & 0.0 & 0.0 & 0.0 & 0.0 & 0.0 & 0.0 & 0.0 & 88.0 \\
\hline
\end{tabular}


De acordo com as distâncias quadradas de Mahalanobis avaliando médias de indivíduos de mesma colônia (Tabela 9) foi construído um dendograma de proximidade morfológica (Figura 19). A distribuição dos grupos neste dendograma foi muito similar à outra topologia (Figura 10), construída com as medidas de todos os indivíduos. A única alteração foi a população de Baraúna - $\mathrm{RN}$, que muda de ramo, agrupando-se com as populações do Sul do país, e tomando o lugar de Alegrete - RS, que deixa de sair como população mais próxima de Santa Maria - RS e passa a ocupar lugar num ramo único, entre o ramo Santa Maria - RS/Baraúna - RN e o restante das populações sulistas, que permaneceram com suas posições inalteradas.

A distribuição gráfica dos grupos de acordo com as análises de discriminantes canônicas (Figura 20) também é muito parecida com a encontrada na análise com os valores dos indivíduos, sendo que a diferença se encontra na escala de distância entre os grupos e também no posicionamento das populações, uma vez que este gráfico se mostra invertido quando comparado com o outro. 


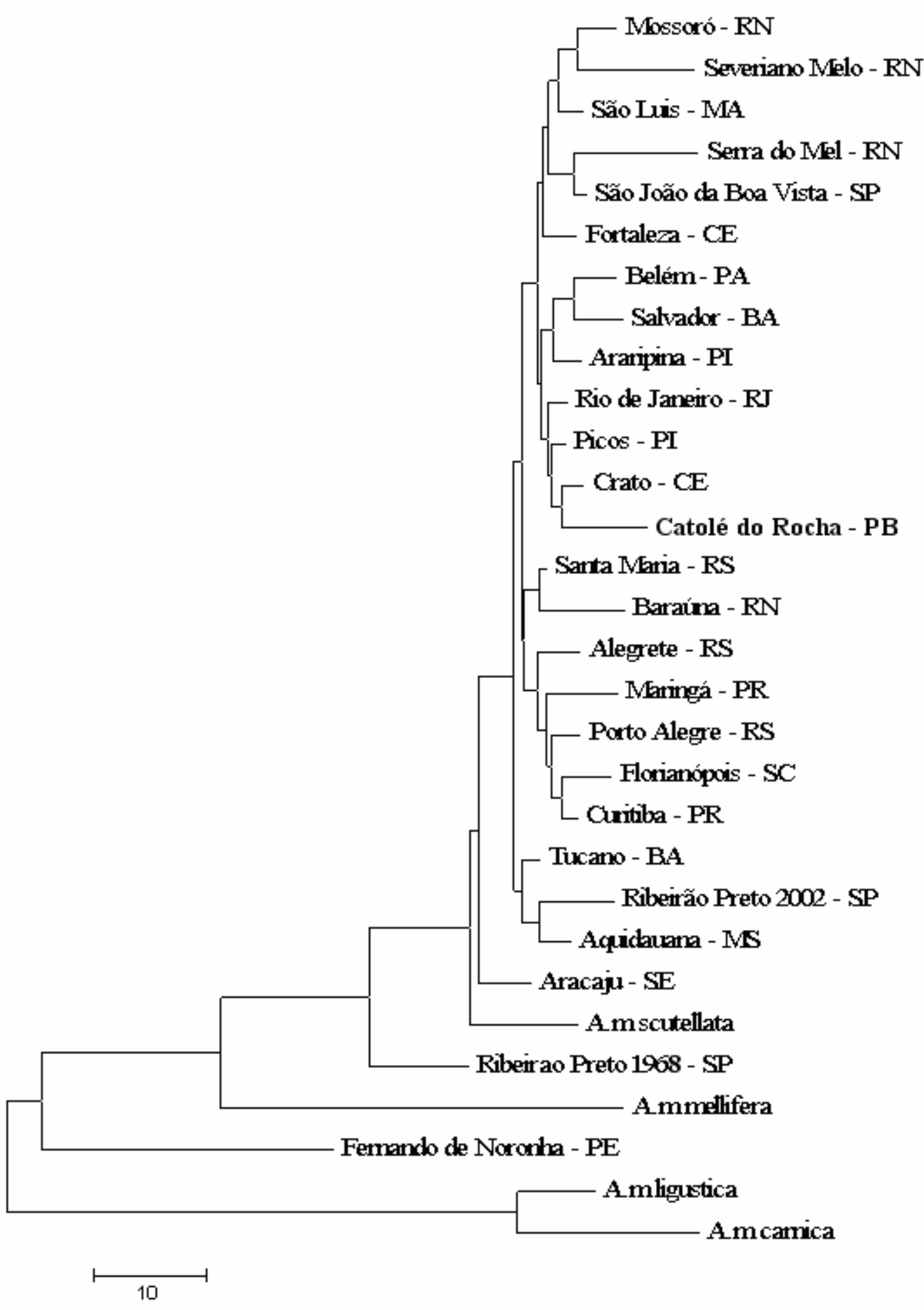

Figura 19: Dendograma de proximidade morfológica entre as populações de abelhas africanizadas, suas subespécies ancestrais e a população de Fernando de Noronha calculado a partir das distâncias de Mahalanobis. Foram utilizadas as médias dos indivíduos de mesma colméia como base de dados. 


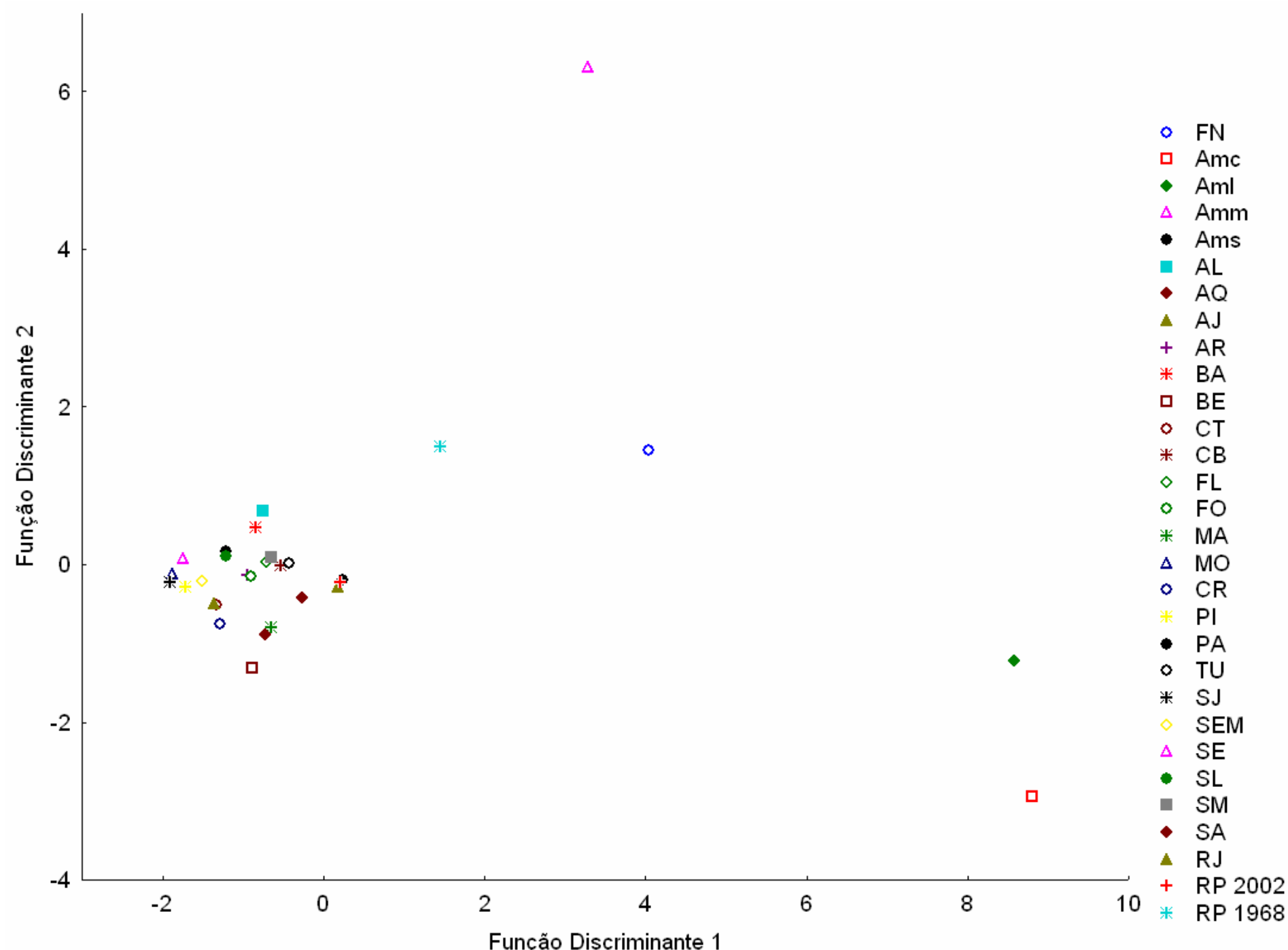

Figura 20: Análise de discriminantes canônicas das populações estudadas. Somente o centróide da distribuição de cada grupo está representado na figura. 
Assim como na análise utilizando-se todos os indivíduos como base de dados, nesta abordagem por colônias também foi feita uma análise adicional eliminando as populações de Fernando de Noronha - PE e Ribeirão Preto - SP - 1968 juntamente com as subespécies puras, de modo a restarem somente as populações de abelhas africanizadas atuais.

Desta maneira, 25 das 34 deformações relativas contribuíram significantemente para a separação dos grupos $(\mathrm{P}<0,05)$. A MANOVA das 34 deformações indicou a presença de diferenças estatísticas significantes (Wilk's $\lambda=0,009 \mathrm{P}<0,0001$ ) entre as populações de abelhas africanizadas.

As distâncias quadradas de Mahalanobis entre os centróides das distribuições de cada grupo se mostraram estatisticamente significantes $(\alpha=0,05)$ (Tabela 12). Diversos pares de populações não apresentaram diferenças estatísticas entre si, a maioria deles relacionada com as populações de Catolé do Rocha - PB (CR) e Mossoró - RN (MO). 
Tabela 12: Distâncias quadradas de Mahalanobis (análise adicional sem as populações de Ribeirão Preto 1968, Fernando de Noronha e as subespécies puras) entre as populações estudadas de abelhas africanizadas atuais (metade superior da tabela) e suas significâncias estatísticas (metade inferior da tabela). Os pontos em destaque indicam os pares de populações nas quais a distância entre os centróides não foi estatisticamente significante $(\alpha=0,05)$.

\begin{tabular}{|c|c|c|c|c|c|c|c|c|c|c|c|c|c|c|c|c|c|c|c|c|c|c|c|c|}
\hline & RP-2002 & $\mathrm{RJ}$ & SA & SM & SL & SE & SEM & SJ & TU & PA & PI & $\mathrm{CT}$ & MO & MA & $\mathrm{FO}$ & FL & $\mathrm{CB}$ & $\mathrm{CR}$ & $\mathrm{BE}$ & $\mathrm{BA}$ & $\mathrm{AR}$ & $\mathrm{AJ}$ & $\mathrm{AQ}$ & $\mathrm{AL}$ \\
\hline RP-2002 & & 11.75 & 14.25 & 8.72 & 14.09 & 15.30 & 7.23 & 8.93 & 12.01 & 11.23 & 10.05 & 13.95 & 15.22 & 10.22 & 9.42 & 11.48 & 9.99 & 23.34 & 28.94 & 11.91 & 6.16 & 17.99 & 10.01 & 17.77 \\
\hline RJ & 0.00 & & 17.70 & 13.83 & 12.66 & 15.37 & 10.75 & 8.62 & 12.43 & 13.28 & 12.73 & 18.33 & 18.67 & 11.84 & 9.22 & 7.41 & 14.43 & 29.69 & 5.55 & 11.87 & 8.92 & 15.66 & 11.16 & 11.11 \\
\hline SA & 00 & 0.00 & & 13.35 & 16.81 & 17.12 & 12.75 & 14.52 & 20.30 & 11.87 & 20.41 & 17.06 & 23.10 & 13.88 & 19.76 & 16.41 & 15.13 & 25.99 & 23.99 & 13.02 & 11.69 & 19.66 & 11.73 & 17.70 \\
\hline SM & & 0.00 & 1.00 & & 14.91 & 9.14 & 7.20 & 9.79 & 11.42 & 7.95 & 10.29 & 11.02 & 16.57 & 6.17 & 12.95 & 8.54 & 8.98 & 15.74 & 19.33 & 9.15 & 6.61 & 9.25 & 6.01 & 17.66 \\
\hline SL & & 0.03 & 1.00 & .01 & & 20.63 & 14.52 & 12.76 & 17.65 & 18.82 & 18.68 & 11.81 & 22.07 & 13.89 & 13.10 & 13.87 & 16.39 & 27.62 & 26.14 & 10.27 & 8.28 & 17.77 & 13.32 & 20.45 \\
\hline SE & & 0.00 & .00 & 0.00 & 0.00 & & 10.69 & 13.09 & 19.42 & 10.68 & 17.27 & 14.60 & 18.64 & 9.61 & 14.99 & 13.24 & 14.43 & 22.08 & 1.13 & 13.73 & 11.52 & 8.73 & 8.85 & 06 \\
\hline SEM & & 00 & 00 & 01 & 0.01 & 0.00 & & 8.14 & 11.36 & 8.84 & 9.89 & 12. & 9.49 & 4.94 & 8.66 & .28 & 8.91 & 93 & 8.76 & & 8.16 & 13.18 & 5.24 & \\
\hline SJ & & & & 00 & 0.03 & 0.00 & 0.00 & & 6.78 & 11.26 & 9.05 & 16.26 & 18.29 & & 5.67 & 8.46 & 10.22 & 26.07 & 22.73 & 10.46 & 8.56 & 16.04 & 6.24 & \\
\hline TU & & & .00 & 0.00 & 0.00 & 0.00 & 0.00 & 0.01 & & 12.60 & 10.53 & 21.91 & 21.92 & 11.02 & 8.56 & 12.86 & 10.81 & 31.02 & 27.69 & 15.93 & 12.04 & 24.01 & 9.59 & 18.50 \\
\hline PA & U & 0.00 & 0.00 & 0.00 & 0.00 & 0.00 & 0.00 & 0.00 & 0.00 & & 12.42 & 10.72 & 12.23 & 6.02 & 9.22 & 9.10 & 9.62 & 15.27 & 16.58 & 7.08 & 7.81 & 14.05 & 6.64 & 13.85 \\
\hline PI & 1 & 0.00 & 0.00 & 0.03 & 0.01 & 0.00 & 0.06 & 0.09 & 0.03 & 0.00 & & 20.27 & 20.24 & 10.64 & 8.69 & 13.30 & 12.80 & 26.61 & 30.80 & 13.33 & 9.23 & 15.45 & 9.65 & 19.48 \\
\hline CT & & 0.00 & 0.00 & 0.04 & 0.44 & 0.00 & 0.02 & 0.00 & 0.00 & 0.01 & 0.00 & & 13.88 & 8.90 & 15.69 & 11.20 & 12.22 & 13.98 & 19.29 & 6.53 & 8.24 & 13.42 & 11.01 & 21.63 \\
\hline MO & 8 & 0.63 & 0.31 & 0.79 & 0.66 & 0.64 & 1.00 & 0.66 & 0.39 & 0.95 & 0.69 & 0.97 & & 11.28 & 16.32 & 16.10 & 17.01 & 21.72 & 31.67 & 14.52 & 14.87 & 16.11 & 12.21 & 21.69 \\
\hline MA & & 0.00 & 0.00 & 0.01 & 0.01 & 0.00 & 0.12 & 0.00 & 0.00 & 0.00 & 0.01 & 0.14 & 0.98 & & 9.01 & 7.53 & 6.04 & 15.49 & 16.53 & 7.10 & 6.97 & 10.15 & 3.05 & 18.38 \\
\hline $\mathrm{FO}$ & & 100 & 0.00 & 0.00 & 0.05 & 0.00 & 0.01 & 0.19 & 0.01 & 0.00 & 0.23 & 0.00 & 0.83 & 0.00 & & 9.42 & 12.47 & 24.76 & 30.19 & 8.52 & 8.50 & 16.70 & 9.25 & 21.31 \\
\hline FL & & OI & 0.00 & 0.00 & 0.01 & 0.00 & 0.00 & 0.00 & 0.00 & 0.00 & 0.00 & 0.03 & 0.80 & 0.00 & 0.00 & & 12.16 & 18.95 & 19.16 & 6.24 & 6.86 & 10.92 & 9.52 & 11.88 \\
\hline $\mathrm{CB}$ & & חा & 0.00 & 0.02 & 0.01 & 0.00 & 0.02 & 0.00 & 0.00 & 0.00 & 0.02 & 0.07 & 0.82 & 0.19 & 0.00 & 0.00 & & 16.05 & 14.97 & 9.54 & 8.14 & 20.18 & 5.52 & 17.85 \\
\hline $\mathrm{CR}$ & & 06 & 17 & 0.84 & 32 & 0.38 & 0.62 & 0.16 & 0.04 & 0.81 & 0.28 & 0.97 & 0.97 & 0.83 & 0.26 & 0.60 & 0.87 & & 30.78 & 16.80 & 15.12 & 23.64 & 15.63 & 25.32 \\
\hline $\mathrm{BE}$ & & 00 & 0 & 0.00 & 0.00 & 0.00 & 0.00 & 0.00 & 0.00 & 0.00 & 0.00 & 0.04 & 0.20 & 0.00 & 0.00 & 0.00 & 0.08 & 0.24 & & 16.37 & 19.67 & 24.20 & 16.06 & 26.22 \\
\hline $\mathrm{BA}$ & 0 & 0.000 & 0.00 & 0.00 & 0.16 & 0.00 & 0.00 & 0.00 & 0.00 & 0.00 & 0.00 & 0.64 & 0.89 & 0.00 & 0.00 & 0.02 & 0.01 & 0.76 & 0.01 & & 6.64 & 10.25 & 8.45 & 16.38 \\
\hline $\mathrm{AR}$ & 0.20 & 0.00 & 0.00 & 0.03 & 0.50 & 0.00 & 0.00 & 0.00 & 0.00 & 0.00 & 0.10 & 0.34 & 0.89 & 0.00 & 0.01 & 0.01 & 0.05 & 0.87 & 0.00 & 0.02 & & 12.11 & 6.27 & 11.22 \\
\hline $\mathrm{AJ}$ & 00 & 0.00 & 0.00 & 0.00 & 0.00 & 0.01 & 0.00 & 0.00 & 0.00 & 0.00 & 0.00 & 0.02 & 0.85 & 0.00 & 0.00 & 0.00 & 0.00 & 0.33 & 0.00 & 0.00 & 0.00 & & 12.05 & 23.67 \\
\hline $\mathrm{AQ}$ & 00 & 0.00 & 0.00 & 0.04 & 0.02 & 0.00 & 0.16 & 0.02 & 0.00 & 0.00 & 0.05 & 0.04 & 0.97 & 0.69 & 0.00 & 0.00 & 0.43 & 0.84 & 0.01 & 0.00 & 0.04 & 0.00 & & 16.75 \\
\hline$A L$ & 0.00 & 0.00 & 0.00 & 0.00 & 0.00 & 0.00 & 0.00 & 0.00 & 0.00 & 0.00 & 0.00 & 0.00 & 0.41 & 0.00 & 0.00 & 0.00 & 0.00 & 0.19 & 0.00 & 0.00 & 0.00 & 0.00 & 0.00 & \\
\hline
\end{tabular}


As funções discriminantes foram capazes de distinguir $67,2 \%$ das colônias analisadas (Tabela 13) enquanto $33,1 \%$ das colônias foram corretamente identificadas nos testes de validação cruzada (Tabela 14). As populações de Belém - PA (BE), com 94,7\% de acerto nas análises discriminantes e 78,9\% nos testes de validação cruzada e Aracaju - SE (AJ), com $89,5 \%$ de acerto nas análises discriminantes e 73,7\% nos testes de validação cruzada merecem destaque.

A partir das distâncias quadradas de Mahalanobis foi construído um dendograma de proximidade morfológica (Figura 21). Neste dendograma, diversos ramos se repetem quando comparados com o dendograma feito com as medidas de todos os indivíduos (Figura 15), enquanto outras populações mudam de posição. Uma delas é o deslocamento do ramo Santa Maria - RS + Baraúna - RN para o ramo das populações do sul do Brasil, enquanto o ramo formado por Crato - CE (CT) + Catolé do Rocha - PB (CR) é deslocado para um ramo com populações do norte e nordeste do Brasil. 
Tabela 13: Classificação de colônias dentro de seus respectivos grupos sem as populações de Ribeirão Preto 1968, Fernando de Noronha e as subespécies puras. As linhas representam as classificações esperadas e as colunas as classificações observadas. Em destaque estão os valores em porcentagem de colônias corretamente classificadas dentro de seus grupos.

\begin{tabular}{|c|c|c|c|c|c|c|c|c|c|c|c|c|c|c|c|c|c|c|c|c|c|c|c|c|}
\hline & AL & $\mathrm{AQ}$ & $\mathrm{AJ}$ & $\mathrm{AR}$ & BA & $\mathrm{BE}$ & CT & $\mathrm{CB}$ & $\mathrm{FL}$ & $\mathrm{FO}$ & MA & $\mathrm{MO}$ & $\mathrm{CR}$ & PI & PA & TU & SJ & SEM & $\mathrm{SE}$ & SL & $\mathrm{SM}$ & SA & $\mathrm{RJ}$ & RP-2002 \\
\hline $\mathrm{AL}$ & 50.0 & 0.0 & 7.1 & 14.3 & 0.0 & 0.0 & 14.3 & 0.0 & 0.0 & 7.1 & 0.0 & 0.0 & 0.0 & 0.0 & 0.0 & 0.0 & 0.0 & 0.0 & 0.0 & 7.1 & 0.0 & 0.0 & 0.0 & 0.0 \\
\hline $\mathrm{AQ}$ & 0.0 & 68.4 & \begin{tabular}{|l|}
0.0 \\
\end{tabular} & 0.0 & 5.3 & 5.3 & 0.0 & 0.0 & 0.0 & 0.0 & 0.0 & 0.0 & 0.0 & 0.0 & 0.0 & 5.3 & 5.3 & 0.0 & 0.0 & 0.0 & 0.0 & 0.0 & 0.0 & 10.5 \\
\hline $\mathrm{AJ}$ & 5.3 & 0.0 & 89.5 & 0.0 & 0.0 & 0.0 & 0.0 & 0.0 & 0.0 & 0.0 & 0.0 & 0.0 & 0.0 & 0.0 & 0.0 & 0.0 & & 0.0 & 0.0 & 0.0 & 5.3 & 0.0 & 0.0 & \\
\hline $\mathrm{AR}$ & 5.3 & 0.0 & 0.0 & 63.2 & 0.0 & 5.3 & 0.0 & 0.0 & 5.3 & 5.3 & 0.0 & 0.0 & 0.0 & 10.5 & 0.0 & 5.3 & 0.0 & 0.0 & 0.0 & 0.0 & 0.0 & 0.0 & 0.0 & 0.0 \\
\hline $\mathrm{BA}$ & 0 & 0.0 & 0.0 & 0.0 & 71.4 & 0.0 & 0.0 & 0.0 & 0.0 & 0.0 & 0.0 & 0.0 & 0.0 & \begin{tabular}{|l|}
0.0 \\
\end{tabular} & 0.0 & 0.0 & & 0.0 & 0.0 & 0.0 & 28.6 & 0.0 & 0.0 & \\
\hline $\mathrm{BE}$ & 0 & 0.0 & 0.0 & 0.0 & 0.0 & 94.7 & 0.0 & 0.0 & 0.0 & 0.0 & 0.0 & 0.0 & 0.0 & 5.3 & 0.0 & 0.0 & 0.0 & 0.0 & 0.0 & 0.0 & 0.0 & 0.0 & 0.0 & .0 \\
\hline CT & 0 & 0.0 & 0.0 & 5.6 & 0.0 & 0.0 & 44.4 & 5.6 & 5.6 & 5.6 & 5.6 & 0.0 & 0.0 & 11.1 & 0.0 & 0.0 & & & 0.0 & 0 & 0.0 & 5.6 & 5.6 & \\
\hline $\mathrm{CB}$ & 5.0 & 0.0 & 5.0 & 0.0 & 5.0 & 0.0 & 5.0 & 65.0 & 0.0 & 5.0 & 0.0 & 0.0 & 0.0 & 5.0 & 0.0 & 0.0 & 0.0 & 0.0 & 0.0 & 0.0 & 0.0 & 0.0 & 5.0 & 0.0 \\
\hline FL & 3 & 0.0 & 0.0 & 0.0 & 0.0 & 0.0 & 5.3 & 0.0 & 84.2 & 0.0 & 5.3 & 0.0 & & 0.0 & 0.0 & 0.0 & & 0 & 0.0 & 0 & 0.0 & 0.0 & 0.0 & \\
\hline $\mathrm{FO}$ & 2.5 & 0.0 & 0.0 & 5.0 & 0.0 & 5.0 & 0.0 & 0.0 & 5.0 & 65.0 & 0.0 & 0.0 & 0.0 & 5.0 & 0.0 & 2.5 & 2.5 & 2. & 0.0 & 0.0 & 2.5 & 0.0 & 0.0 & 2. \\
\hline MA & 0 & 0.0 & 0.0 & 11.1 & 0.0 & 0.0 & 0.0 & 11.1 & \begin{tabular}{|l|}
11.1 \\
\end{tabular} & 11.1 & 55.6 & 0.0 & 0.1 & 0.0 & 0.0 & 0.0 & 0.0 & 0.1 & 0.0 & 0.0 & 0.0 & 0.0 & 0.0 & .0 \\
\hline $\mathrm{MO}$ & 0.0 & 0.0 & 0.0 & 0.0 & 12.5 & 0.0 & 0.0 & 0.0 & \begin{tabular}{|l|}
0.0 \\
\end{tabular} & 0.0 & 0.0 & 50.0 & 0.0 & 0.0 & 0.0 & 0.0 & 0.0 & 0.1 & 0.0 & 12.5 & 12.5 & 12.5 & 0.0 & 0 \\
\hline $\mathrm{CR}$ & 0.0 & 0.0 & 0.0 & 0.0 & 0.0 & 0.0 & 0.0 & 0.0 & 0.0 & 0.0 & 0.0 & 0.0 & 100.0 & 0.0 & 0.0 & 0.0 & 0.0 & 0.0 & 0.0 & 0.0 & 0.0 & 0.0 & 0.0 & 1.0 \\
\hline PI & 0 & 0.0 & 0.0 & 0.0 & 0.0 & 0.0 & 4.0 & 4.0 & 0.0 & 8.0 & 0.0 & 0.0 & \begin{tabular}{|l|}
0.0 \\
\end{tabular} & 72.0 & \begin{tabular}{l|l}
0.0 \\
\end{tabular} & 4.0 & & 0 & 0.0 & & 0.0 & 0.0 & 8.0 & \\
\hline PA & 0.0 & 6.7 & 0.0 & 0.0 & 0.0 & 0.0 & 0.0 & 6.7 & 0.0 & 6.7 & 0.0 & 0.0 & 0.0 & 0.0 & 73.3 & 0.0 & 0.0 & 0.0 & 0.0 & 6.7 & 0.0 & 0.0 & 0.0 & 0.0 \\
\hline TU & 4 & 0.0 & 0.0 & 0.0 & 0.0 & 4.8 & 0.1 & 0.0 & 0.0 & 4.8 & 0.0 & 0.0 & & 9.5 & 0.0 & 61.9 & 0.0 & 0 & 0.0 & & 0.0 & 4.8 & 0.0 & \\
\hline SJ & 0.0 & 0.0 & 0.0 & 8.3 & 0.0 & 0.0 & 0.0 & 0.0 & 0.0 & 0.0 & 0.0 & 0.0 & 0.0 & 8.3 & 0.0 & 8.3 & 75.0 & 0.0 & 0.0 & 0.0 & 0.0 & 0.0 & 0.0 & 0.0 \\
\hline SEM & 0.0 & 0.0 & 0.0 & 0.0 & 0.0 & 0.0 & 0.0 & 0.0 & 0.0 & 0.0 & 0.0 & 0.0 & & 0.0 & 0.0 & 0.0 & 0.0 & 100.0 & 0.0 & 0.0 & 0.0 & 0.0 & 0.0 & \\
\hline SE & 0.0 & 0.0 & 0.0 & 0.0 & 0.0 & 0.0 & 0.0 & 0.0 & 0.0 & 0.0 & 0.0 & 0.0 & 0.0 & 0.0 & 0.0 & 0.0 & 0.0 & 0.0 & 100.0 & 0.0 & 0.0 & 0.0 & 0.0 & 0.0 \\
\hline SL & 0.0 & 5.0 & 0.0 & 5.0 & 0.0 & 0.0 & 0.0 & 5.0 & 0.0 & 5.0 & 0.0 & 5.0 & & 0.0 & 0.0 & 10.0 & 5.0 & 0.0 & 0.0 & 60.0 & 0.0 & 0.0 & 0.0 & \\
\hline SM & 5.6 & 5.6 & 0.0 & 0.0 & 5.6 & 0.0 & 0.0 & 0.0 & 0.0 & 0.0 & 0.0 & 5.6 & & 5.6 & 5.6 & 0.0 & 5.6 & 0.0 & 0.0 & 5.6 & 44.4 & 0.0 & 11.1 & 0.0 \\
\hline SA & 0.0 & 0.0 & 0.0 & 0.0 & 0.0 & 0.0 & 0.0 & 0.0 & 0.0 & 7.1 & 0.0 & 7.1 & 0.0 & 0.0 & 0.0 & 7.1 & 0.0 & 0.0 & 0.0 & 7.1 & \begin{tabular}{|l|}
0.0 \\
\end{tabular} & 71.4 & 0.0 & 0.0 \\
\hline $\mathrm{RJ}$ & 0.0 & 0.0 & 0.0 & 10.0 & 5.0 & 5.0 & 10.0 & 5.0 & 0.0 & 5.0 & 0.0 & 0.0 & 0.0 & 10.0 & 0.0 & 0.0 & 5.0 & 0.0 & 0.0 & 0.0 & 5.0 & 5.0 & 35.0 & 0.0 \\
\hline$P-2002$ & 0.0 & 0.0 & 5.3 & 0.0 & 0.0 & 0.0 & 0.0 & 0.0 & 0.0 & 5.3 & 0.0 & 0.0 & 0.0 & 0.0 & 0.0 & 5.3 & 0.0 & 0.0 & 0.0 & 0.0 & 0.0 & 0.0 & 0.0 & 84.2 \\
\hline
\end{tabular}


Tabela 14: Identificação de colônias por validação cruzada dentro de seus respectivos grupos sem as populações de Ribeirão Preto 1968, Fernando de Noronha e as subespécies puras. As linhas representam as classificações esperadas e as colunas as classificações observadas. Em destaque estão os valores em porcentagem de colônias corretamente classificadas dentro de seus grupos.

\begin{tabular}{|c|c|c|c|c|c|c|c|c|c|c|c|c|c|c|c|c|c|c|c|c|c|c|c|c|}
\hline & $\mathrm{AL}$ & $\mathrm{AQ}$ & $\mathrm{AJ}$ & $\mathrm{AR}$ & $\mathrm{BA}$ & $\mathrm{BE}$ & CT & CB & FL & $\mathrm{FO}$ & MA & $\mathrm{MO}$ & $\mathrm{CR}$ & PI & PA & TU & SJ & SEMI & SE & SL & SMI & SA & $\mathrm{RJ}$ & RP-2002 \\
\hline $\mathrm{AL}$ & 14.3 & 7.1 & 14.3 & 7.1 & 0.0 & 0.0 & 7.1 & 7.1 & 7.1 & 7.1 & 0.0 & 0.0 & 0.0 & 0.0 & 0.0 & 7.1 & 0.0 & 7.1 & 0.0 & 7.1 & 7.1 & 0.0 & 0.0 & 0.0 \\
\hline $\mathrm{AQ}$ & 0.0 & 31.6 & 0.0 & 0.0 & 5.3 & 10.5 & 5.3 & 0.0 & 0.0 & 0.0 & 0.0 & 0.0 & 0.0 & 0.0 & 10.5 & 10.5 & 5.3 & 0.0 & 0.0 & 0.0 & 5.3 & 0.0 & 0.0 & 15.8 \\
\hline$A_{\mathrm{J} J}$ & 5.3 & 5.3 & 73.7 & 0.0 & 0.0 & 0.0 & 0.0 & 5.3 & 0.0 & 0.0 & 0.0 & 0.0 & 0.0 & 0.0 & 0.0 & 0.0 & 0.0 & 0.0 & 0.0 & 5.3 & 0.0 & 0.0 & 0.0 & 5.3 \\
\hline $\mathrm{AR}$ & 5.3 & 0.0 & 10.5 & 26.3 & 0.0 & 10.5 & 5.3 & 0.0 & 5.3 & 5.3 & 0.0 & 0.0 & 0.0 & 15.8 & 0.0 & 5.3 & 0.0 & 0.0 & 0.0 & 0.0 & 5.3 & 5.3 & 0.0 & 0.0 \\
\hline $\mathrm{BA}$ & 0.0 & 0.0 & 0.0 & 0.0 & 14.3 & 0.0 & 0.0 & 14.3 & 0.0 & 0.0 & 0.0 & 0.0 & 0.0 & 14.3 & 0.0 & 0.0 & 0.0 & 0.0 & 0.0 & 14.3 & 42.9 & 0.0 & 0.0 & 0.0 \\
\hline $\mathrm{BE}$ & 0.0 & 0.0 & 0.0 & 0.0 & 0.0 & 78.9 & 0.0 & 0.0 & 0.0 & 0.0 & 0.0 & 0.0 & 0.0 & 5.3 & 0.0 & 0.0 & 0.0 & 0.0 & 5.3 & 0.0 & 0.0 & 5.3 & 5.3 & 0.0 \\
\hline $\mathrm{CT}$ & 11.1 & 0.0 & 0.0 & 11.1 & 0.0 & 0.0 & 22.2 & 5.6 & 5.6 & 5.6 & 5.6 & 0.0 & 0.0 & 11.1 & 0.0 & 0.0 & 5.6 & 0.0 & 0.0 & 0.0 & 0.0 & 5.6 & 11.1 & 0.0 \\
\hline $\mathrm{CB}$ & 5.0 & 0.0 & 10.0 & 0.0 & 5.0 & 0.0 & 5.0 & 20.0 & 20.0 & 5.0 & 0.0 & 0.0 & 0.0 & 5.0 & 10.0 & 0.0 & 0.0 & 0.0 & 0.0 & 0.0 & 0.0 & 0.0 & 15.0 & 0.0 \\
\hline FL & 5.3 & 5.3 & 0.0 & 0.0 & 0.0 & 0.0 & 5.3 & 10.5 & 47.4 & 0.0 & 10.5 & 0.0 & 0.0 & 5.3 & 0.0 & 0.0 & 0.0 & 0.0 & 0.0 & 0.0 & 5.3 & 0.0 & 5.3 & 0.0 \\
\hline $\mathrm{FO}$ & 2.5 & 2.5 & 0.0 & 5.0 & 0.0 & 5.0 & 0.0 & 0.0 & 5.0 & 47.5 & 0.0 & 0.0 & 0.0 & 10.0 & 0.0 & 2.5 & 7.5 & 2.5 & 0.0 & 2.5 & 5.0 & 0.0 & 0.0 & 2.5 \\
\hline MA & 0.0 & 0.0 & 0.0 & 22.2 & 11.1 & 0.0 & 0.0 & 0.0 & 11.1 & 11.1 & 44.4 & 0.0 & 0.0 & 0.0 & 0.0 & 0.0 & 0.0 & 0.0 & 0.0 & 0.0 & 0.0 & 0.0 & 0.0 & 0.0 \\
\hline $\mathrm{MO}$ & 0.0 & 0.0 & 0.0 & 0.0 & 12.5 & 0.0 & 0.0 & 0.0 & 0.0 & 0.0 & 0.0 & 25.0 & 0.0 & 12.5 & 0.0 & 0.0 & 0.0 & 0.0 & 0.0 & 12.5 & 12.5 & 25.0 & 0.0 & 0.0 \\
\hline $\mathrm{CR}$ & 0.0 & 0.0 & 0.0 & 0.0 & 0.0 & 0.0 & 66.7 & 0.0 & 0.0 & 33.3 & 0.0 & 0.0 & 0.0 & 0.0 & 0.0 & 0.0 & 0.0 & 0.0 & 0.0 & 0.0 & 0.0 & 0.0 & 0.0 & 0.0 \\
\hline PI & 0.0 & 0.0 & 0.0 & 8.0 & 0.0 & 0.0 & 4.0 & 4.0 & 0.0 & 24.0 & 0.0 & 0.0 & 0.0 & 24.0 & 0.0 & 8.0 & 4.0 & 0.0 & 0.0 & 0.0 & 8.0 & 4.0 & 12.0 & 0.0 \\
\hline PA & 6.7 & 6.7 & 0.0 & 0.0 & 6.7 & 0.0 & 6.7 & 13.3 & 6.7 & 13.3 & 0.0 & 0.0 & 0.0 & 0.0 & 13.3 & 13.3 & 0.0 & 0.0 & 0.0 & 6.7 & 6.7 & 0.0 & 0.0 & 0.0 \\
\hline TU & 4.8 & 0.0 & 0.0 & 0.0 & 0.0 & 4.8 & 0.0 & 4.8 & 9.5 & 4.8 & 0.0 & 0.0 & 0.0 & 9.5 & 0.0 & 42.9 & 0.0 & 0.0 & 0.0 & 0.0 & 4.8 & 4.8 & 0.0 & 9.5 \\
\hline $\mathrm{SJ}$ & 8.3 & 0.0 & 0.0 & 8.3 & 0.0 & 0.0 & 16.7 & 8.3 & 0.0 & 8.3 & 0.0 & 0.0 & 0.0 & 25.0 & 0.0 & 8.3 & 8.3 & 0.0 & 0.0 & 0.0 & 0.0 & 0.0 & 8.3 & 0.0 \\
\hline SEMI & 0.0 & 0.0 & 0.0 & 33.3 & 0.0 & 0.0 & 0.0 & 0.0 & 0.0 & 33.3 & 0.0 & 0.0 & 0.0 & 0.0 & 0.0 & 0.0 & 33.3 & 0.0 & 0.0 & 0.0 & 0.0 & 0.0 & 0.0 & 0.0 \\
\hline $\mathrm{SE}$ & 0.0 & 0.0 & 0.0 & 0.0 & 0.0 & 0.0 & 0.0 & 0.0 & 0.0 & 16.7 & 0.0 & 0.0 & 0.0 & 0.0 & 0.0 & 0.0 & 33.3 & 0.0 & 33.3 & 0.0 & 0.0 & 0.0 & 16.7 & 0.0 \\
\hline SL & 0.0 & 5.0 & 5.0 & 5.0 & 0.0 & 0.0 & 5.0 & 5.0 & 0.0 & 10.0 & 0.0 & 5.0 & 0.0 & 0.0 & 5.0 & 20.0 & 5.0 & 0.0 & 5.0 & 20.0 & 0.0 & 0.0 & 5.0 & 0.0 \\
\hline SMI & 5.6 & 5.6 & 0.0 & 5.6 & 16.7 & 0.0 & 0.0 & 0.0 & 0.0 & 0.0 & 0.0 & 11.1 & 0.0 & 5.6 & 5.6 & 0.0 & 5.6 & 0.0 & 0.0 & 5.6 & 11.1 & 0.0 & 11.1 & 11.1 \\
\hline SA & 0.0 & 7.1 & 0.0 & 0.0 & 7.1 & 7.1 & 0.0 & 0.0 & 0.0 & 7.1 & 7.1 & 7.1 & 0.0 & 7.1 & 0.0 & 7.1 & 0.0 & 0.0 & 0.0 & 7.1 & 0.0 & 35.7 & 0.0 & 0.0 \\
\hline $\mathrm{RJ}$ & 0.0 & 0.0 & 0.0 & 10.0 & 5.0 & 10.0 & 10.0 & 10.0 & 0.0 & 10.0 & 0.0 & 0.0 & 0.0 & 10.0 & 0.0 & 0.0 & 10.0 & 0.0 & 5.0 & 0.0 & 5.0 & 5.0 & 10.0 & 0.0 \\
\hline RP-2002 & 0.0 & 10.5 & 5.3 & 0.0 & 0.0 & 0.0 & 0.0 & 0.0 & 0.0 & 10.5 & 0.0 & 0.0 & 0.0 & 0.0 & 0.0 & 10.5 & 0.0 & 0.0 & 0.0 & 0.0 & 10.5 & 0.0 & 0.0 & 52.6 \\
\hline
\end{tabular}




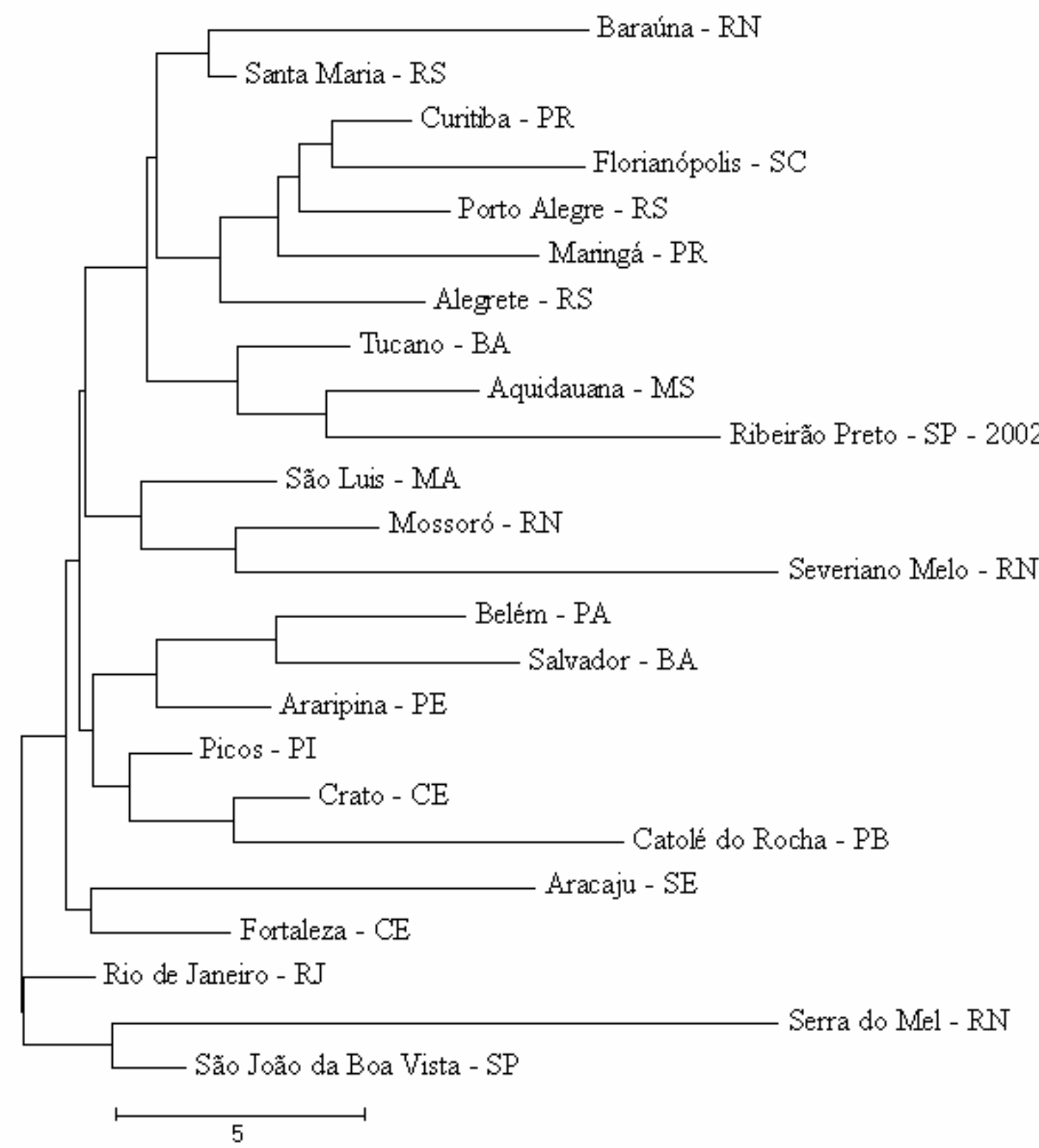

Figura 21: Dendograma de proximidade morfológica das populações de abelhas africanizadas construído a partir das distâncias de Mahalanobis entre os centróides dos grupos.

A representação gráfica da análise discriminante (Figura 22), assim como na análise com os indivíduos mostrou a população de Ribeirão Preto 2002 separada das demais, enquanto nenhum padrão de morfoclusters pode ser encontrado no gráfico. 


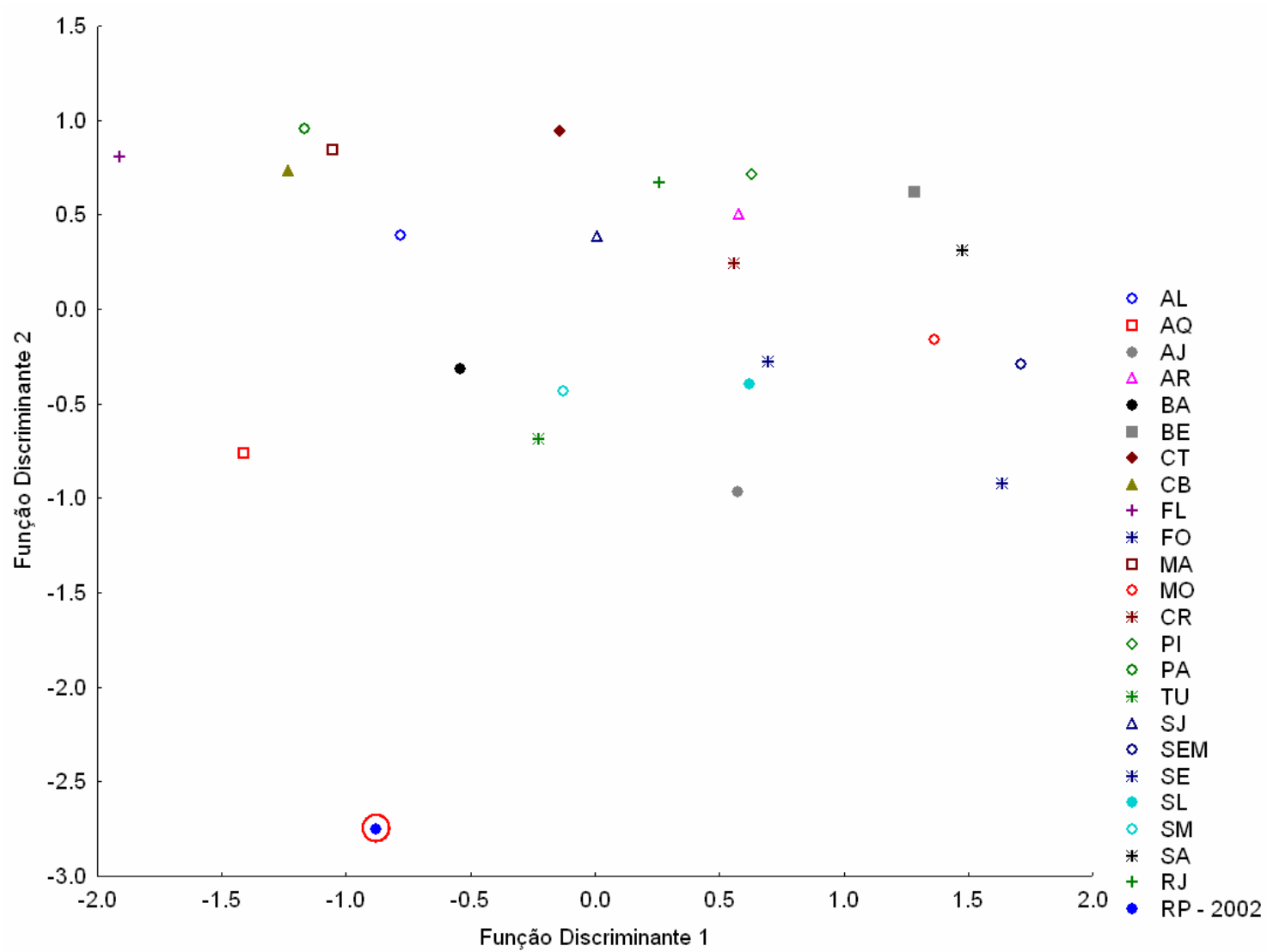

Figura 22: Representação gráfica da análise de discriminantes canônicas das populações de abelhas africanizadas analisadas quanto à média dos indivíduos provenientes de mesma colônia. Destacada pelo grande círculo vermelho encontra-se a população de Ribeirão Preto 2002.

\subsection{3 - J-ABIS}

O J-ABIS é um sistema completamente automatizado, cuja função primária é a identificação de espécies de abelhas. Como o desenvolvimento desse sistema teve um objetivo muito claro, o software não permite aos usuários o acesso aos dados brutos utilizados na classificação e identificação dos indivíduos. Apesar de diversas modificações terem sido propostas e já estarem sendo trabalhadas no software, a versão utilizada neste trabalho ainda não nos permite trabalhar diretamente com os dados, mostrando somente os resultados finais.

O ABIS nos permite dois tipos de análises estatística durante as análises discriminantes, uma linear (LDA) e a outra não linear (KDA) e, desta maneira, os dois tipos de análises foram realizadas. 
O ABIS necessita ainda de um número mínimo de 30 indivíduos por grupo para formar os seus padrões de grupos. Isso impossibilitou a análise das populações de Catolé do Rocha - PB e Severiano Melo - RN, que foram então, excluídas desta parte dos resultados.

$\mathrm{Na}$ primeira abordagem, onde foram analisadas todas as populações de abelhas africanizadas, a população de Fernando de Noronha - PE e as subespécies puras de acordo com funções discriminantes lineares, $86,1 \%$ dos indivíduos foram corretamente classificados dentro de seus respectivos grupos. Nos testes de validação cruzada onde foram utilizados $10 \%$ e $20 \%$ dos indivíduos como desconhecidos para identificação, $43,5 \%$ e $42,8 \%$ dos indivíduos foram respectivamente classificados dentro de seus grupos de origem.

O dendograma de proximidade morfológica (Figura 23) construído a partir das distâncias quadradas de Mahalanobis entre os grupos (Tabela 15) mostra a população de Fernando de Noronha - PE como sendo a mais distante de todas as outras, ficando isolada num ramo na base do dendograma. As subespécies da linhagem C (Ruttner, 1988), A. m. ligustica e $A$. m. carnica são posicionadas no próximo ramo, seguidas por um ramo isolado de $A$. m. mellifera. A subespécie mais próxima das populações africanizadas é a $A . m$. scutellata, com as duas populações de Ribeirão Preto, a de 2002 e a de 1968 como os próximos ramos da árvore, seguidos de todas as outras populações. Apesar de incongruências entre os agrupamentos, alguns grupos geograficamente próximos ficam posicionados de acordo com a região de origem das populações, como as populações do Rio Grande do Norte e algumas cidades do sul do Brasil, que ficam agrupadas em seus respectivos ramos. 


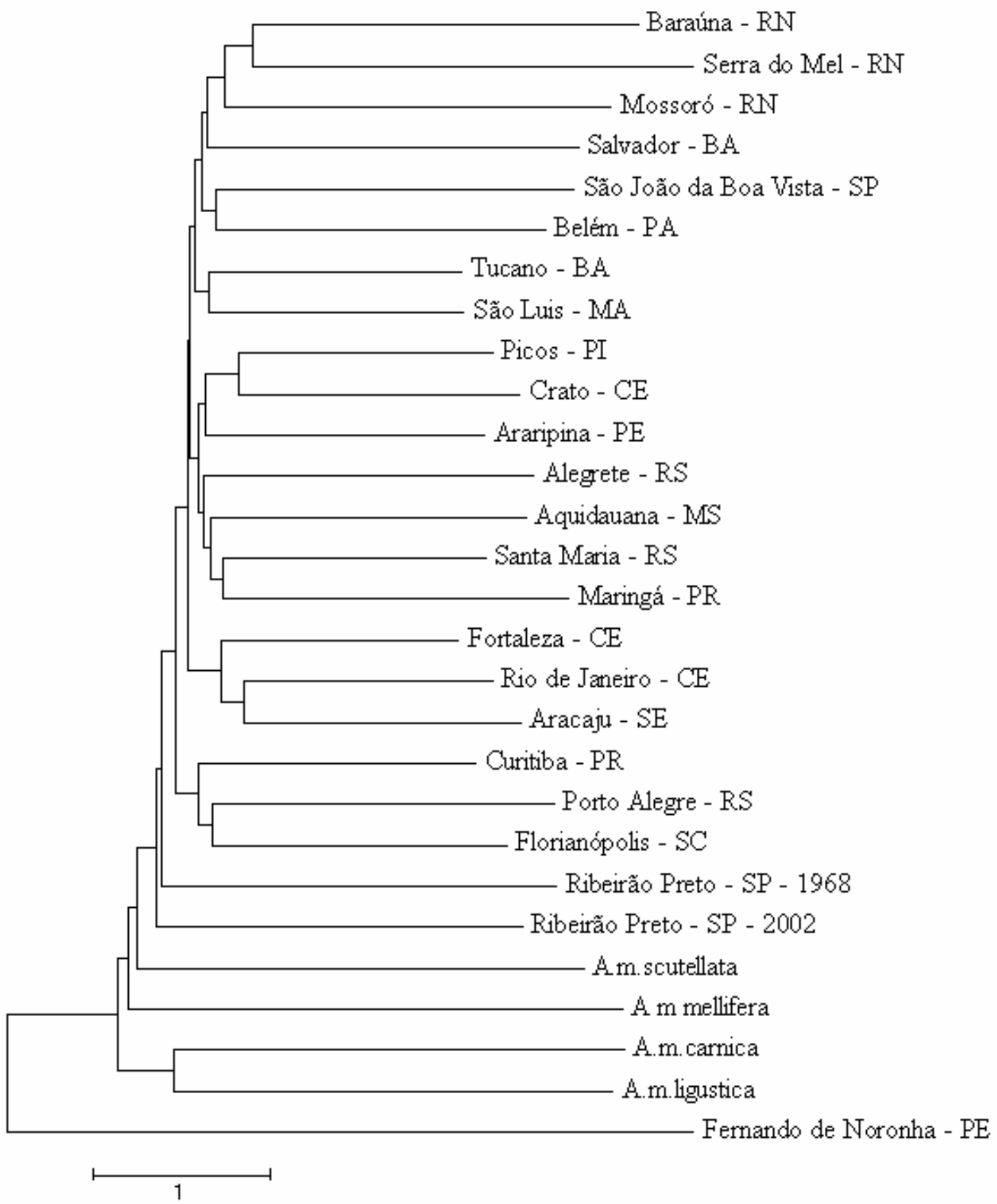

Figura 23: Dendograma de proximidade morfológica entre os grupos estudados construído a partir das distâncias quadradas de Mahalanobis calculadas por análises discriminantes lineares (LDA) pelo software ABIS. 
Tabela 15: Distâncias quadradas de Mahalanobis entre os pares de grupos estudados calculados de acordo com funções discriminantes lineares (LDA).

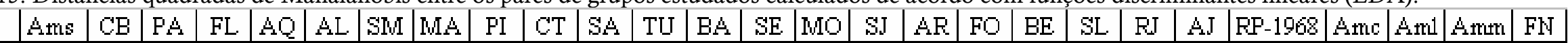

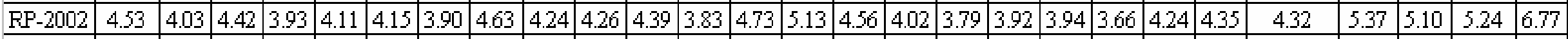

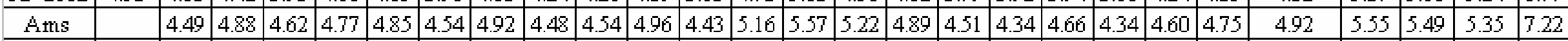

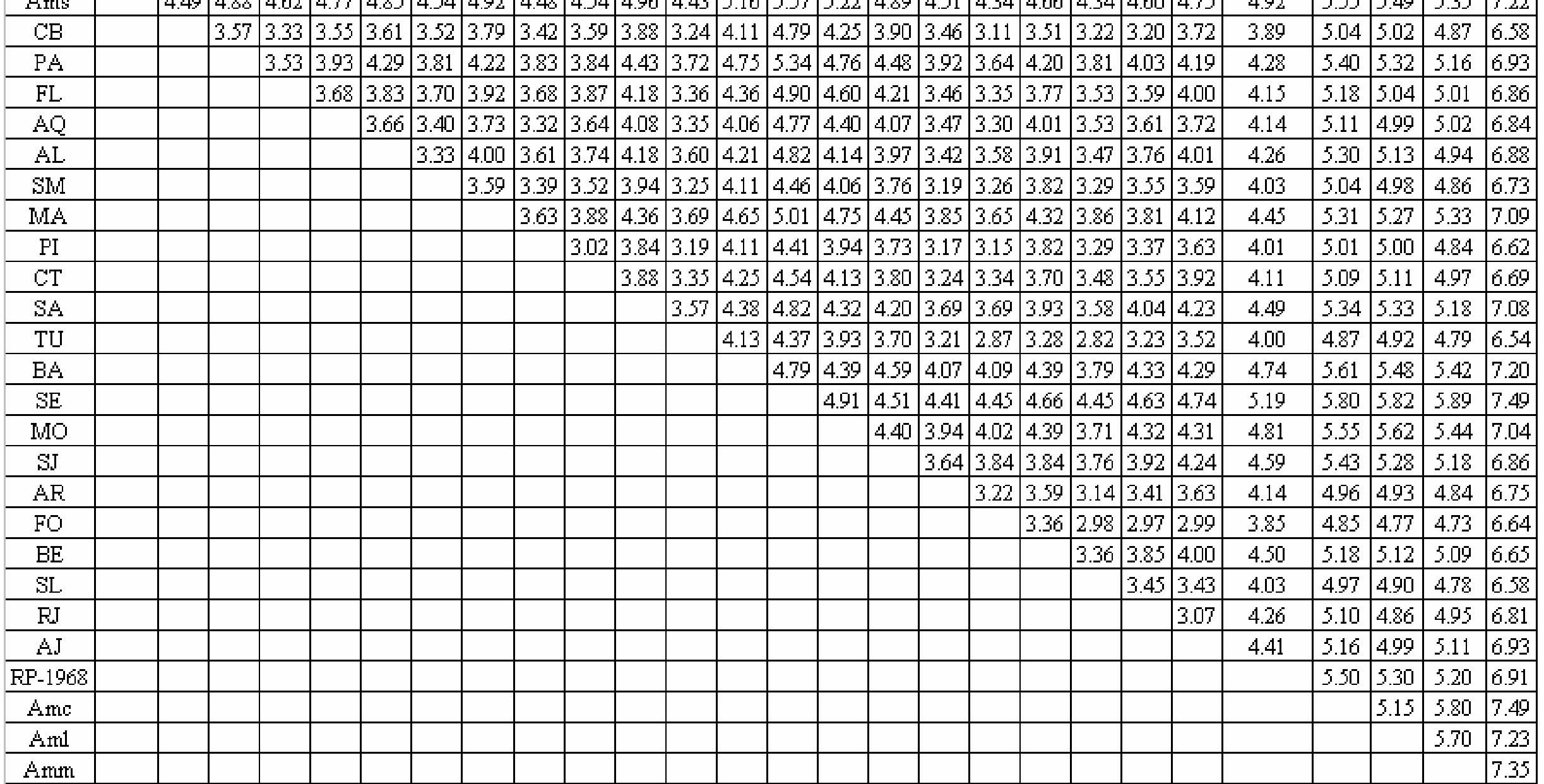


Já na abordagem não linear utilizando os mesmos grupos da análise anterior os valores de classificação e identificação por validação cruzada aumentam. As análises não lineares foram capazes de separar corretamente $99,9 \%$ dos indivíduos dentro de seus respectivos grupos, acertando ainda 52\% e 50,9\% nos testes de validação cruzada utilizando $10 \%$ e $20 \%$ dos indivíduos como desconhecidos para identificação.

As análises discriminantes não-lineares se mostraram mais eficientes na discriminação dos grupos e na identificação dos indivíduos do que as análises lineares. Devido à diferença nas análises, as distâncias de Mahalanobis entre os grupos também mudam (Tabela 16) e modificam um pouco a disposição dos grupos no dendograma de proximidade morfológica (Figura 24). Na nova disposição, Fernando de Noronha - PE continua sendo o grupo mais diferenciado de todos, se posicionando em um ramo isolado na base do dendograma. Uma subdivisão do segundo ramo separa as subespécies ancestrais de todas as outras populações africanizadas. No ramo das subespécies puras, $A$. m. ligustica e A. m. carnica ficam agrupadas mais proximamente, seguidas por $A$. m. mellifera e $A . m$. scutellata. As duas populações de Ribeirão Preto ficam posicionadas na base do dendograma e, assim como no dendograma produzido pelas análises lineares, alguns grupos geograficamente próximos ficam posicionados no mesmo ramo do dendograma, como as populações do Rio Grande do Norte e algumas populações do sul do Brasil. 


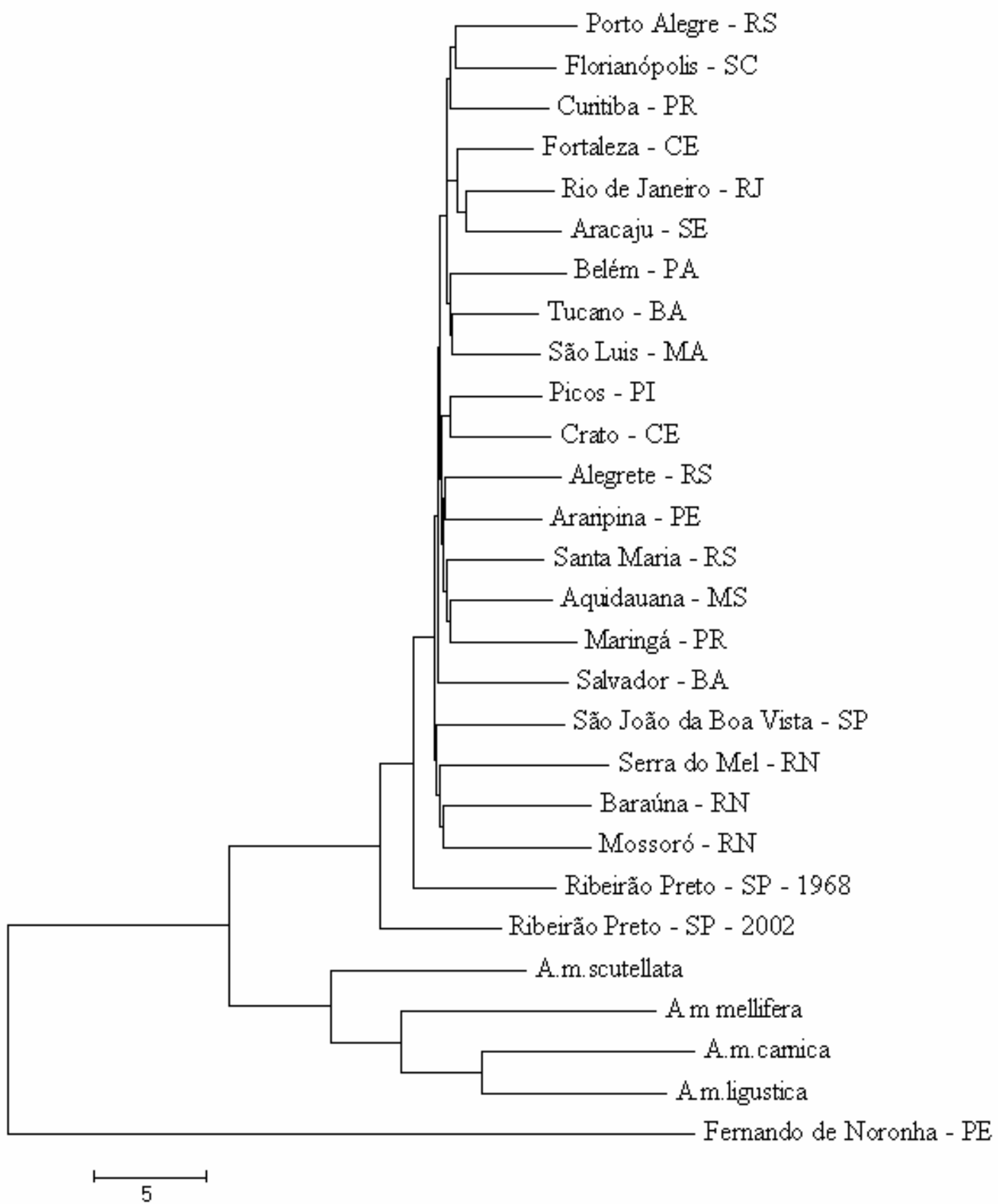

Figura 24: Dendograma de proximidade morfológica entre os grupos estudados construído a partir das distâncias quadradas de Mahalanobis entre pares de populações calculadas a partir de análises discriminantes não lineares (KDA) pelo software ABIS. 
Tabela 16: Distâncias quadradas de Mahalanobis entre os pares de grupos estudados calculadas de acordo com funções discriminantes não lineares (KDA).

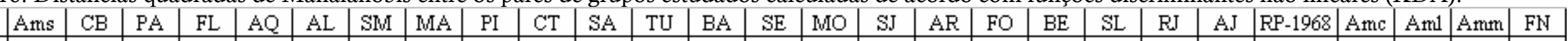

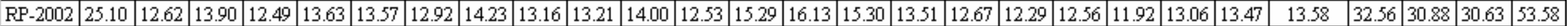

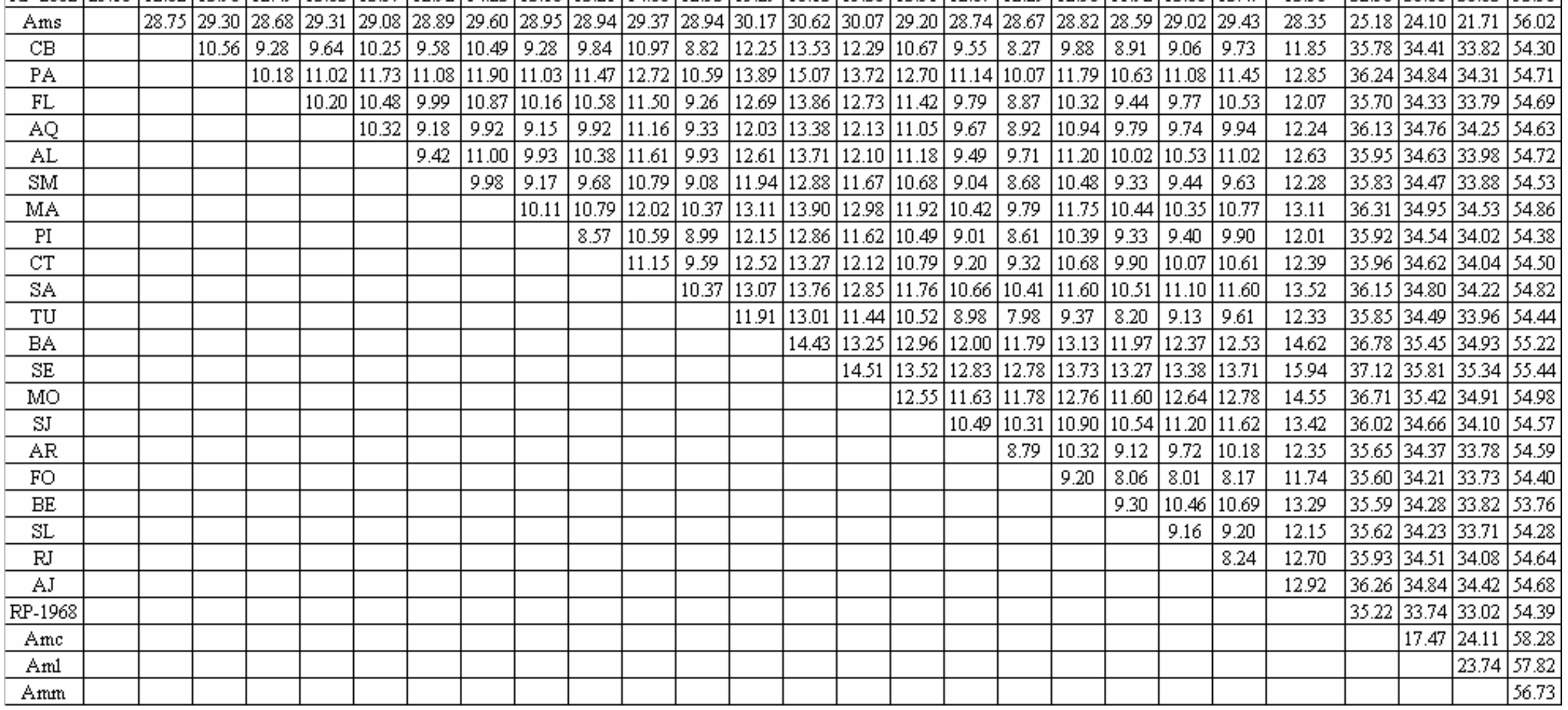


Como um dos objetivos do presente trabalho é testar as novas metodologias morfométricas na identificação das diferentes populações de abelhas africanizadas, uma análise adicional foi feita, retirando-se da amostra as subespécies puras e as populações de Fernando de Noronha - PE e de Ribeirão Preto - SP coletada em 1968. Desta maneira, assim como na análise anterior realizada junto ao ABIS, os dois tipos de análises discriminantes foram realizados com as populações de abelhas africanizadas.

Na primeira delas, utilizando análises discriminantes lineares, o ABIS foi capaz de distinguir $86,6 \%$ dos indivíduos dentro de seus respectivos grupos enquanto os testes de validação cruzada foram capazes de identificar $31,7 \%$ e $39,7 \%$ quando foram utilizados, respectivamente, $10 \%$ e $20 \%$ dos indivíduos como desconhecidos para identificação.

O dendograma de proximidade morfológica (Figura 25), assim como nas outras abordagens, mostra alguns agrupamentos esperados, como é o caso das populações do Rio Grande do Norte e de algumas populações do Sul do Brasil, como Porto Alegre - RS, Florianópolis - SC e Curitiba - PR. As distâncias quadradas de Mahalanobis utilizadas na construção do dendograma são apresentadas na Tabela 17. 


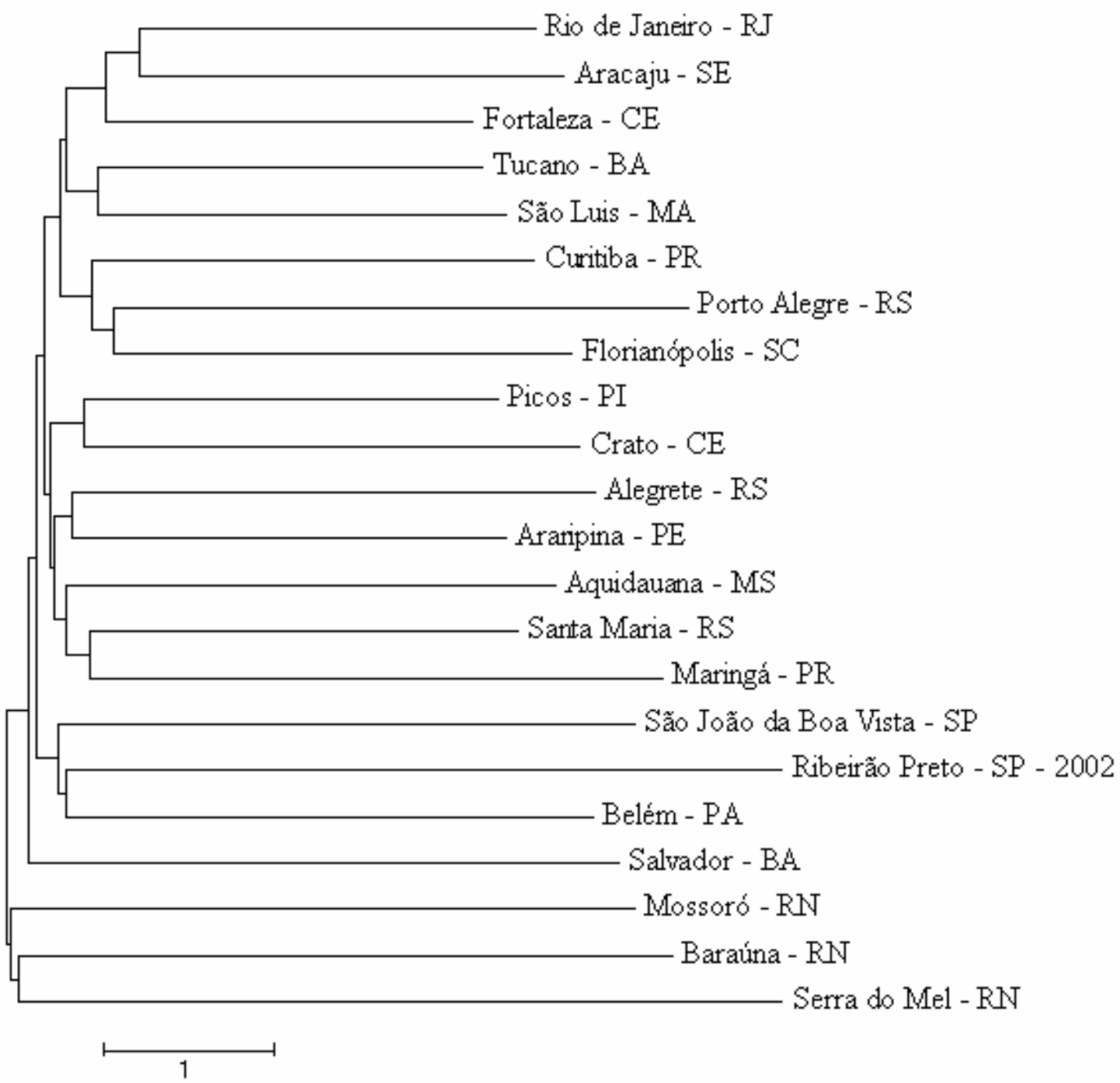

Figura 25: Dendograma de proximidade morfológica das populações de abelhas africanizadas construído a partir das distâncias quadradas de Mahalanobis calculadas pelo ABIS através de análises discriminantes lineares (LDA).

Por fim, foram ainda testadas as análises discriminantes não lineares (Tabela 18) nas populações de abelhas africanizadas. Tais análises atingiram 100\% de classificações corretas de acordo com as análises discriminantes e $38,2 \%$ e $37,5 \%$ nos testes de validação cruzada utilizando $10 \%$ e $20 \%$ respectivamente como indivíduos desconhecidos para classificação. As distâncias quadradas de Mahalanobis foram utilizadas na construção do dendograma da Figura 26, que mostra as proximidades morfológicas das amostras das populações de abelhas africanizadas. As abelhas de Ribeirão Preto 2002 estão posicionadas na base do dendograma isoladas das demais amostras analisadas, independente da posição geográfica delas. 
Tabela 17: Distâncias quadradas de Mahalanobis entre os pares de populações de abelhas africanizadas calculado a partir de análises lineares (LDA) pelo software ABIS.

\begin{tabular}{|l|l|l|l|l|l|l|l|l|l|l|l|l|l|l|l|l|l|l|l|l|} 
CB & PA & FL & AQ & AL & SM & MA & PI & CT & SA & TU & BA & SE & MO & SJ & AR & FO & BE & SL & RJ & AJ \\
\hline
\end{tabular} \begin{tabular}{|l|l|l|l|l|l|l|l|l|l|l|l|l|l|l|l|l|l|l|l|l|l|}
\hline RP-2002 & 7.25 & 7.89 & 7.19 & 7.48 & 7.76 & 7.20 & 8.23 & 7.36 & 7.66 & 8.09 & 7.10 & 8.57 & 9.03 & 8.30 & 7.57 & 7.17 & 6.92 & 7.26 & 6.86 & 7.39 & 7.60 \\
\hline
\end{tabular}

\begin{tabular}{|c|c|c|c|c|c|c|c|c|c|c|c|c|c|c|c|c|c|c|c|c|}
\hline $\mathrm{CB}$ & 6.05 & & 5.86 & 6.11 & 5.72 & 6.44 & 5.45 & 6.24 & 6.49 & 5.27 & 7.09 & 7.87 & 6.90 & 6.37 & 5.69 & 5.10 & 5.79 & 5.22 & 5.26 & 5.90 \\
\hline PA & & 6.04 & 6.66 & 7.10 & 6.43 & 7.26 & 6.54 & 6.86 & 7.27 & 6.19 & 8.05 & 8.85 & 7.74 & \begin{tabular}{|l|l|}
7.49 \\
\end{tabular} & 6.62 & 6.03 & 7.12 & 6.37 & 6.70 & 6.89 \\
\hline FL & & & 6.14 & 6.54 & 5.92 & 6.61 & 5.90 & 6.52 & 6.79 & 5.48 & 7.42 & 7.97 & 7.41 & \begin{tabular}{|l|}
6.82 \\
\end{tabular} & 5.79 & 5.50 & 6.22 & 5.70 & 5.69 & 6.29 \\
\hline $\mathrm{AQ}$ & & & & 6.26 & 5.61 & 6.33 & 5.37 & 6.16 & 6.71 & 5.61 & 6.92 & 7.77 & 7.14 & 6.64 & 5.83 & 5.46 & 6.52 & 5.92 & 5.88 & 5.96 \\
\hline $\mathrm{AL}$ & & & & & 5.75 & 6.80 & 6.07 & 6.59 & 6.96 & 5.87 & 7.43 & 8.29 & 6.92 & 6.54 & 5.83 & 5.97 & 6.62 & 6.06 & 6.17 & 6.51 \\
\hline SM & & & & & & 6.09 & \begin{tabular}{|l}
5.47 \\
\end{tabular} & 6.05 & 6.51 & 5.47 & 7.03 & 7.42 & 6.70 & 6.26 & \begin{tabular}{|l|l|}
5.30 \\
\end{tabular} & \begin{tabular}{|l|}
5.22 \\
\end{tabular} & 6.20 & 5.53 & \begin{tabular}{|l|}
5.63 \\
\end{tabular} & 5.77 \\
\hline MA & & & & & & & 6.14 & 6.82 & 7.19 & 6.25 & 7.99 & 7.97 & 7.80 & 7.38 & 6.48 & 6.23 & 7.24 & 6.65 & 6.43 & 6.76 \\
\hline PI & & & & & & & & 5.55 & 6.27 & 5.22 & 6.90 & 7.22 & 6.41 & 6.10 & 5.29 & \begin{tabular}{|l|}
5.03 \\
\end{tabular} & 6.19 & 5.41 & 5.48 & 5.75 \\
\hline CT & & & & & & & & & 6.77 & 5.90 & $7.40^{\circ}$ & 7.76 & 7.07 & 6.45 & \begin{tabular}{|l|}
5.76 \\
\end{tabular} & \begin{tabular}{|l|l|}
5.75 \\
\end{tabular} & 6.49 & 5.98 & 6.17 & 6.60 \\
\hline $\mathrm{SA}$ & & & & & & & & & & 6.10 & 7.66 & 8.15 & 7.34 & 6.84 & 6.24 & \begin{tabular}{|l|l|}
6.13 \\
\end{tabular} & 6.73 & 6.12 & 6.59 & 6.77 \\
\hline TU & & & & & & & & & & & 7.19 & \begin{tabular}{|l|}
7.37 \\
\end{tabular} & 6.21 & 6.10 & 5.27 & 4.78 & 5.55 & 4.76 & 5.36 & 5.64 \\
\hline $\mathrm{BA}$ & & & & & & & & & & & & 8.25 & 7.57 & 7. & 6.92 & 6.88 & 7.47 & 6.79 & 7.0 & 7.26 \\
\hline $\mathrm{SE}$ & & & & & & & & & & & & & 8.02 & 7.68 & \begin{tabular}{|l|l|}
7.38 \\
\end{tabular} & \begin{tabular}{|l|l|}
7.32 \\
\end{tabular} & 7.94 & 7.54 & \begin{tabular}{|l|}
7.63 \\
\end{tabular} & 7.85 \\
\hline MO & & & & & & & & & & & & & & $\begin{array}{ll}7.26 \\
\end{array}$ & 6.56 & 6.60 & 7.38 & 6.47 & 7.08 & 7.14 \\
\hline SJ & & & & & & & & & & & & & & & 6.19 & \begin{tabular}{|c|}
6.20 \\
\end{tabular} & 6.50 & 6.20 & 6.48 & 6.78 \\
\hline $\mathrm{AR}$ & & & & & & & & & & & & & & & & \begin{tabular}{|l|l|}
5.37 \\
\end{tabular} & 6.06 & 5.44 & 5.78 & 5.84 \\
\hline $\mathrm{FO}$ & & & & & & & & & & & & & & & & & 5.41 & 4.86 & \begin{tabular}{|l|}
4.86 \\
\end{tabular} & 4.82 \\
\hline $\mathrm{BE}$ & & & & & & & & & & & & & & & & & & 5.54 & 6.22 & 6.28 \\
\hline $\mathrm{SL}$ & & & & & & & & & & & & & & & & & & & 5.56 & 5.47 \\
\hline $\mathrm{RJ}$ & & & & & & & & & & & & & & & & & & & & 4.98 \\
\hline
\end{tabular}

O dendograma de proximidade morfológica (Figura 26) mostra ainda algumas

divergências entre quando comparado com o dendograma construído com as distâncias

lineares, mas no geral, os ramos estão de acordo, aumentando somente as distâncias entre

os grupos, uma vez que as análises não lineares se mostram mais eficientes na

discriminação dos grupos.

Tabela 18: Distâncias quadradas de Mahalanobis entre os pares de populações de abelhas africanizadas calculadas por funções discriminantes não lineares (KDA) pelo ABIS.

\begin{tabular}{|l|l|l|l|l|l|l|l|l|l|l|l|l|l|l|l|l|l|l|l|l|} 
CB & PA & FL & AQ & AL & SM & MA & PI & CT & SA & TU & BA & SE & MO & SJ & AR & FO & BE & SL & RJ & AJ \\
\hline
\end{tabular}

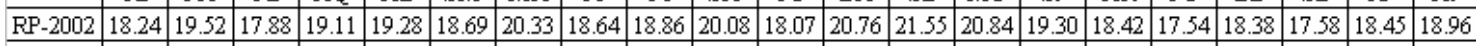

\begin{tabular}{|c|c|c|c|c|c|c|c|c|c|c|c|c|c|c|c|c|c|c|c|c|}
\hline $\mathrm{CB}$ & 12.43 & 11.14 & 11.40 & 12.38 & 11.61 & 13.10 & 11.12 & 11.87 & 13.15 & 10.41 & 14.58 & 15.52 & 14.62 & 12.88 & 11.35 & 9.91 & 12.35 & 10.69 & 10.94 & 11.63 \\
\hline PA & & 12.24 & 13.00 & 13.87 & 13.09 & 14.54 & 12.93 & 13.58 & 14.90 & 12.55 & 16.23 & 17.18 & 16.09 & 14.90 & 13.14 & 12.01 & 14.48 & 12.73 & 13.13 & 13.52 \\
\hline FL & & & 12.05 & 12.61 & 11.90 & 13.41 & 11.93 & 12.52 & 13.54 & 10.78 & 14.98 & 15.88 & 14.99 & 13.45 & 11.61 & 10.31 & 12.77 & 11.11 & 11.52 & 12.45 \\
\hline $\mathrm{AQ}$ & & & & 12.05 & 10.93 & 12.15 & 10.78 & 11.66 & 13.16 & 11.10 & 14.40 & 15.15 & 14.23 & 13.17 & 11.34 & 10.47 & 13.46 & 11.50 & 11.47 & 11.86 \\
\hline $\mathrm{AL}$ & & & & & 11.34 & 13.32 & 11.76 & 12.35 & 13.70 & 11.91 & 15.00 & 15.83 & 14.40 & 13.43 & 11.47 & 11.55 & 13.75 & 12.08 & 12.47 & 13.15 \\
\hline SM & & & & & & 12.21 & 10.88 & 11.53 & 12.84 & 10.86 & 14.40 & 14.76 & 13.94 & 12.83 & 10.76 & 10.40 & 13.05 & 11.15 & 11.34 & 11.86 \\
\hline MA & & & & & & & 12.38 & 13.27 & 14.43 & 12.74 & 15.93 & 16.21 & 15.41 & 14.47 & 12.59 & 12.25 & 14.95 & 12.96 & 12.88 & 13.42 \\
\hline PI & & & & & & & & 10.40 & 12.39 & 10.56 & 14.43 & 14.69 & 13.83 & 12.54 & 10.50 & 10.21 & 12.90 & 11.08 & 11.18 & 11.84 \\
\hline $\mathrm{CT}$ & & & & & & & & & 13.19 & 11.40 & 14.85 & 15.18 & 14.39 & 12.89 & 11.03 & 11.10 & 13.41 & 11.79 & 12.08 & 12.70 \\
\hline SA & & & & & & & & & & 12.28 & 15.74 & 15.85 & 15.21 & 14.00 & 12.65 & 12.24 & 14.27 & 12.61 & 13.22 & 13.92 \\
\hline TU & & & & & & & & & & & 14.28 & 14.82 & 13.66 & 12.52 & 10.68 & 9.22 & 11.52 & 9.65 & 10.67 & 11.42 \\
\hline $\mathrm{BA}$ & & & & & & & & & & & & 17.10 & 16.13 & 15.57 & 14.18 & 13.96 & 16.10 & 14.44 & 14.78 & 15.18 \\
\hline $\mathrm{SE}$ & & & & & & & & & & & & & 16.97 & 15.66 & 14.69 & 14.51 & 16.20 & 15.24 & 15.42 & 15.93 \\
\hline $\mathrm{MO}$ & & & & & & & & & & & & & & 15.17 & 13.81 & 13.88 & 15.76 & 13.92 & 15.01 & 15.39 \\
\hline SJ & & & & & & & & & & & & & & & 12.36 & 12.20 & 13.74 & 12.65 & 13.30 & 14.04 \\
\hline $\mathrm{AR}$ & & & & & & & & & & & & & & & & 10.25 & 12.78 & 10.88 & 11.47 & 12.10 \\
\hline $\mathrm{FO}$ & & & & & & & & & & & & & & & & & 11.29 & 9.42 & 9.57 & 9.90 \\
\hline $\mathrm{BE}$ & & & & & & & & & & & & & & & & & & 11.62 & 12.82 & 13.31 \\
\hline $\mathrm{SL}$ & & & & & & & & & & & & & & & & & & & 10.96 & 11.17 \\
\hline $\mathrm{RJ}$ & & & & & & & & & & & & & & & & & & & & 10.09 \\
\hline
\end{tabular}




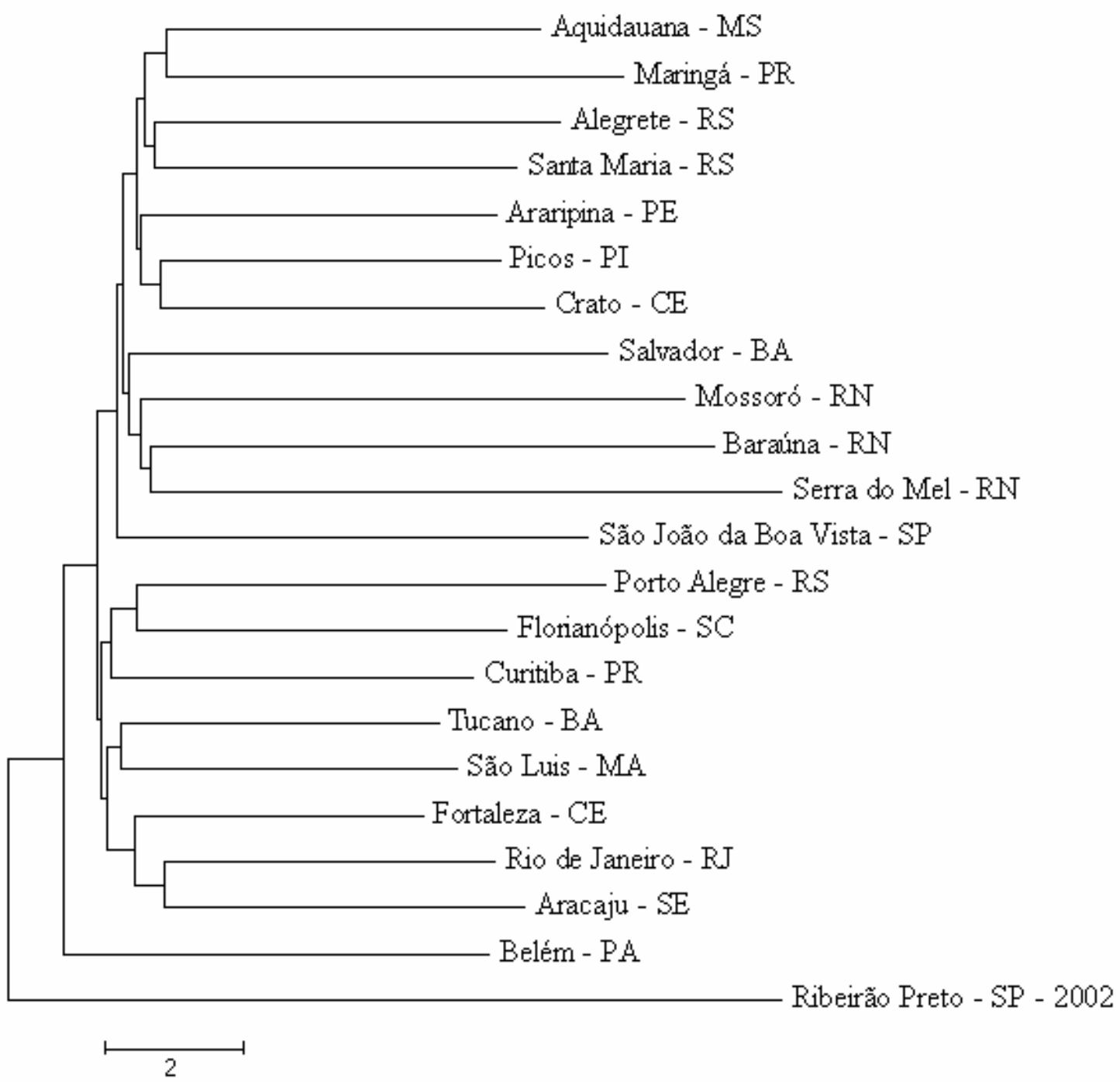

Figura 26: Dendograma de proximidade morfológica construído a partir das distâncias quadradas de Mahalanobis calculadas com funções discriminantes não lineares (KDA) pelo software ABIS.

\subsection{4 - DNA Mitocondrial.}

De acordo com Hall \& Smith (1991), existe um polimorfismo dentro do locus Cit B do DNA mitocondrial de Apis mellifera que diferencia as subespécies de origem Européia e Africana. Tal polimorfismo é evidenciado quando o produto de PCR deste locus é digerido com a enzima de restrição $B g l \mathrm{II}$, uma vez que o sítio de restrição está presente somente nas abelhas de origem européia. Assim, a presença de uma única banda no gel após a digestão do produto indica uma origem materna africana enquanto a presença de duas bandas indica a origem européia. 
Dentre as 394 colônias de abelhas africanizadas de populações brasileiras que tiveram seu mitótipo identificado neste trabalho, 391 apresentaram mitótipo africano (Figura 27) e somente duas colônias de Florianópolis - SC e uma de Maringá - PR apresentaram mitótipo europeu, o que representa menos de $1 \%$ de todas as amostras estudadas.

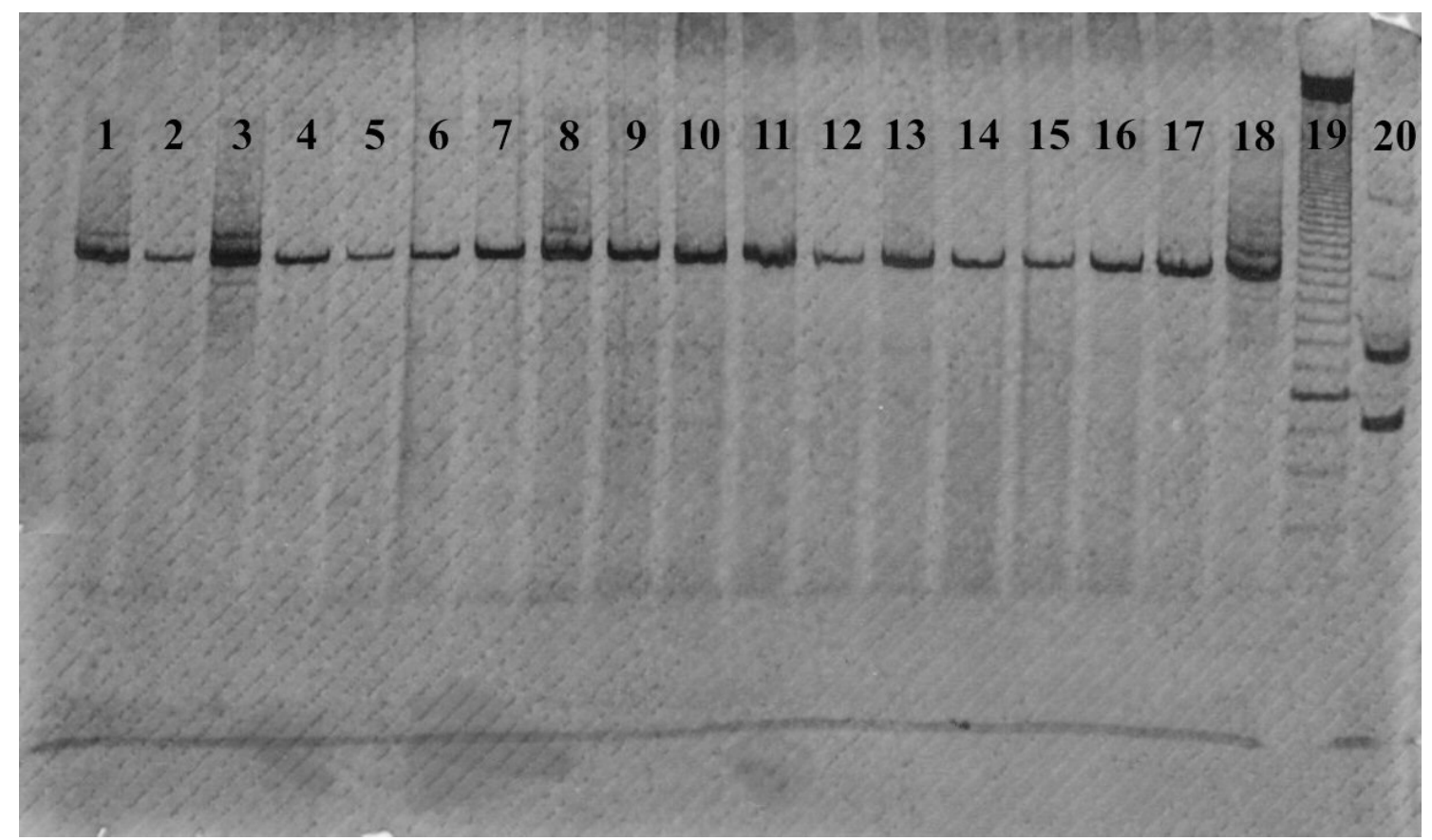

Figura 27: Gel com as amostras de DNA mitocondrial de Salvador - BA (raias 1 a 13) e Severiano Melo - RN (raias 14 a 18). O marcador de peso molecular encontra-se na raia 19 e a amostra controle com DNA mitocondrial de A. m. ligustica encontra-se na raia 20.

As três colônias que apresentaram o DNA mitocondrial como sendo de origem européia foram ainda identificadas quanto a sua origem européia, ou seja, como sendo pertencente ao ramo evolutivo $\mathrm{M}$ ou ao ramo $\mathrm{C}$, sendo que todos os mitótipos apresentaram a região de restrição para a região intergênica COI-COII sendo, portanto, identificadas como pertencendo ao ramo $\mathrm{C}$, o mesmo de $A$. m. ligustica.

\section{2 - Mudanças na população de Ribeirão Preto - SP entre 1968 e 2002.}

\subsection{1 - Morfometria Tradicional.}

Juntamente com os indivíduos das populações de abelhas africanizadas de Ribeirão Preto 1968 e 2002, foram também medidas as três características (comprimento e largura 
da asa anterior e comprimento da célula radial da asa anterior) em 50 exemplares de $A . m$. scutellata provenientes de 10 colônias da região da Pretória na África do Sul. Todos os valores medidos nas abelhas africanas se mostraram intermediários aos encontrados nas duas populações de Ribeirão Preto - SP, mesmo que às vezes não apresentassem diferenças estatísticas.

As medidas tomadas junto às asas das duas populações de Ribeirão Preto - SP e de A. m. scutellata mostram que a população de 1968 apresenta uma média maior para todas as medidas quando comparada com as outras populações, sendo que o comprimento da asa anterior é a única medida estatisticamente diferente nas três populações $(\mathrm{P}<0,05)$. $\mathrm{A}$ largura da asa anterior não foi estatisticamente diferente em nenhum dos grupos e o comprimento da célula radial é diferente entre as duas populações de abelhas africanizadas $(\mathrm{P}<0,05)$ sendo que a medida de $A . m$. scutellata não difere de nenhuma das duas (Tabela 19).

Tabela 19: Medidas de morfometria tradicional nas duas populações de Ribeirão Preto - SP coletadas nos anos de 1968 e 2002. CA = comprimento da asa anterior, LA = largura da asa anterior e $C R=$ comprimento da célula radial. Letras iguais na mesma coluna indicam ausência de diferenças estatísticas e letras diferentes indicam presença de diferença estatística $(P=0,05)$

\begin{tabular}{|c|c|c|c|c|}
\hline & CA & LA & CR & N \\
\hline RP 2002 & $0.822 \pm 0.014^{\mathrm{a}}$ & $0.289 \pm 0.008^{\mathrm{a}}$ & $0.296 \pm 0.007^{\mathrm{a}}$ & 82 \\
\hline RP 1968 & $0.867 \pm 0.012^{\mathrm{b}}$ & $0.303 \pm 0.010^{\mathrm{a}}$ & $0.315 \pm 0.010^{\mathrm{b}}$ & 112 \\
\hline A.mscutellata & $0.844 \pm 0.010^{\mathrm{c}}$ & $0.301 \pm 0.011^{\mathrm{a}}$ & $0.309 \pm 0.012^{\mathrm{a}} \mathrm{b}$ & 50 \\
\hline
\end{tabular}

\subsection{2 - Morfometria Geométrica}

Assim como na comparação das abelhas africanizadas do Brasil, neste item as amostras também foram analisadas quanto aos indivíduos e quanto à média dos indivíduos de mesma colônia, visando estabelecer o melhor protocolo de análise para esta nova metodologia.

$\mathrm{Na}$ análise utilizando as médias de todos os indivíduos, 31 das 34 medidas de deformações relativas geradas $\mathrm{p}$ contribuíram significativamente $(\mathrm{P}<0,05)$ para a separação dos seis grupos estudados (A. m. ligustica, A. m. carnica, A. m. mellifera, A. m. scutellata e as duas amostras de populações de abelhas africanizadas). 
De acordo com a MANOVA, diferenças significativas foram encontradas entre os grupos (Wilk's $\lambda=0.00687 ; \mathrm{P}<0.0001$ ). A análise discriminante mostrou que as distâncias quadradas de Mahalanobis (Tabela 20) entre os centróides das distribuições foram estatisticamente significantes a um $\mathrm{P}<0,0001$.

Tabela 20: Distâncias morfológicas entre os pares de grupos estudados calculados a partir das deformações relativas. $\mathrm{Na}$ metade superior da tabela encontram-se as distâncias quadradas de Mahalanobis e na metade inferior sua significância estatística

\begin{tabular}{|c|c|c|c|c|c|c|}
\hline & A.m. carnica & $\mathrm{RP}-2002$ & A.m. ligustica & $\mathrm{RP}-1968$ & A.m. mellifera & A.m. scutellata \\
\hline A.m. carnica & & 37.68 & 9.32 & 32.98 & 34.54 & 27.08 \\
\hline $\mathrm{RP}-2002$ & 0.0001 & & 34.04 & 12.43 & 24.18 & 15.14 \\
\hline A.m. ligustica & 0.0001 & 0.0001 & & 29.83 & 29.68 & 23.65 \\
\hline $\mathrm{RP}-1968$ & 0.0001 & 0.0001 & 0.0001 & & 21.60 & 12.40 \\
\hline A.m. mellifera & 0.0001 & 0.0001 & 0.0001 & 0.0001 & & 22.47 \\
\hline A.m. scutellata & 0.0001 & 0.0001 & 0.0001 & 0.0001 & 0.0001 & \\
\hline
\end{tabular}

As funções lineares discriminantes geradas foram capazes de classificar corretamente $92,7 \%$ de todos os indivíduos dentro de seus respectivos grupos (Tabela 21) e 85\% dos indivíduos foram corretamente identificados nos testes de validação cruzada (Tabela 22).

Tabela 21: Classificação de indivíduos dentro de seus respectivos grupos. As linhas representam as classificações observadas e as colunas representam as classificações esperadas. Em destaque estão os valores em porcentagem de indivíduos corretamente classificados dentro de seus grupos.

\begin{tabular}{|c|c|c|c|c|c|c|}
\hline & A.m. carnica & $\mathrm{RP}-2002$ & A.m. ligustica & $\mathrm{RP}-1968$ & A.m. mellifera & A.m. scutellata \\
\hline A.m. carnica & 96.0 & 0.0 & 4.0 & 0.0 & 0.0 & 0.0 \\
\hline $\mathrm{RP}-2002$ & 2.0 & 96.0 & 0.0 & 2.0 & 0.0 & 0.0 \\
\hline A.m. ligustica & 12.0 & 0.0 & 88.0 & 0.0 & 0.0 & 0.0 \\
\hline $\mathrm{RP}-1968$ & 0.0 & 8.0 & 0.0 & 82.0 & 2.0 & 8.0 \\
\hline A.m. mellifera & 0.0 & 0.0 & 0.0 & 0.0 & 100.0 & 0.0 \\
\hline A.m. scutellata & 0.0 & 0.0 & 0.0 & 6.0 & 0.0 & 94.0 \\
\hline
\end{tabular}

Tabela 22: Identificação de indivíduos por validação cruzada dentro dos grupos estudados. As linhas representam as classificações observadas e as colunas representam as classificações esperadas. Em destaque estão os valores percentuais de indivíduos corretamente classificados dentro de seus grupos.

\begin{tabular}{|c|c|c|c|c|c|c|} 
& A.m. carnica & $\mathrm{RP}-2002$ & A.m. ligustica & $\mathrm{RP}-1968$ & A.m. mellifera & A.m. scutellata \\
\hline A.m. carnica & 92.0 & 0.0 & 8.0 & 0.0 & 0.0 & 0.0 \\
\hline $\mathrm{RP}-2002$ & 4.0 & 82.0 & 4.0 & 6.0 & 0.0 & 4.0 \\
\hline A.m. ligustica & 16.0 & 0.0 & 82.0 & 0.0 & 0.0 & 2.0 \\
\hline $\mathrm{RP}-1968$ & 0.0 & 10.0 & 0.0 & 76.0 & 2.0 & 12.0 \\
\hline A.m. mellifera & 0.0 & 0.0 & 0.0 & 0.0 & 98.0 & 2.0 \\
\hline A.m. scutellata & 0.0 & 6.0 & 2.0 & 10.0 & 2.0 & 80.0 \\
\hline
\end{tabular}


A partir das distâncias quadradas de Mahalanobis foi construído um dendograma de proximidade morfológica (Figura 28) entre os grupos estudados e nesta topologia, as subespécies da linhagem C (Ruttner, 1988) A. m. ligustica e A. m. carnica ficam agrupadas em um ramo na base do dendograma, seguidas de um ramo simples onde $A$. $m$. mellifera fica isolada. Como grupo irmão deste ramo, ficam agrupadas as duas populações africanizadas e A. m. scutellata, sendo que as duas populações africanizadas são mais próximas entre si do que quando comparadas com a subespécie africana.

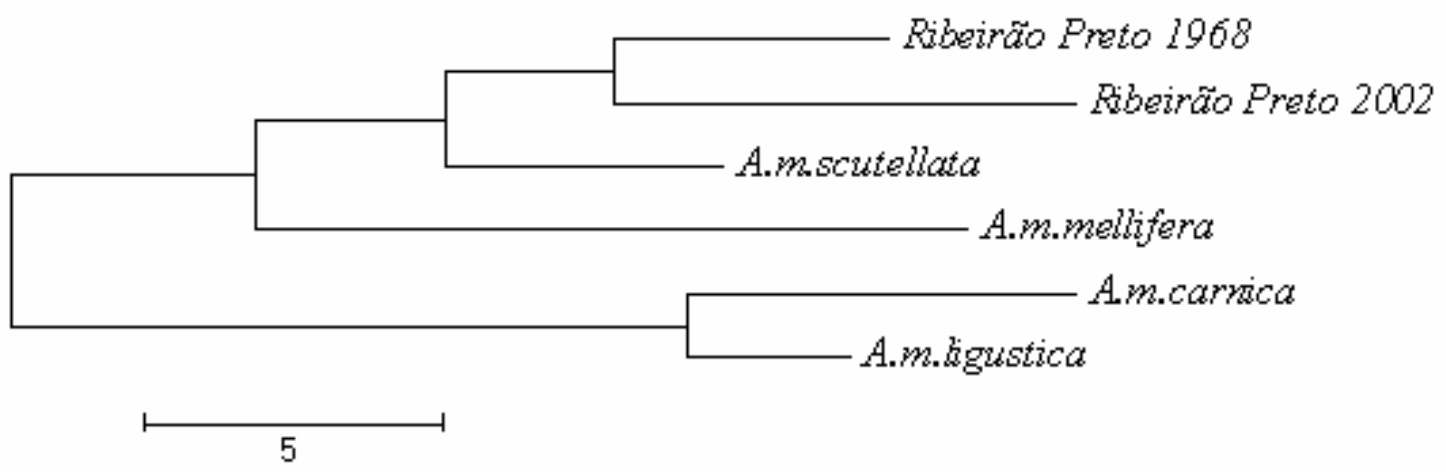

Figura 28: Dendograma de proximidade morfológica construído a partir das distâncias quadradas de Mahalanobis geradas a partir das análises de deformações relativas.

A distribuição gráfica dos pontos mostra três grupamentos bem distintos que correspondem aos ramos evolutivos propostos por Ruttner (1988). As A. m. ligustica e as A. m. carnica formam um grupo, A. m. mellifera fica separada das demais e um terceiro grupo, formado por A. m. scutellata e as populações africanizadas se sobrepõe (Figura 29). 


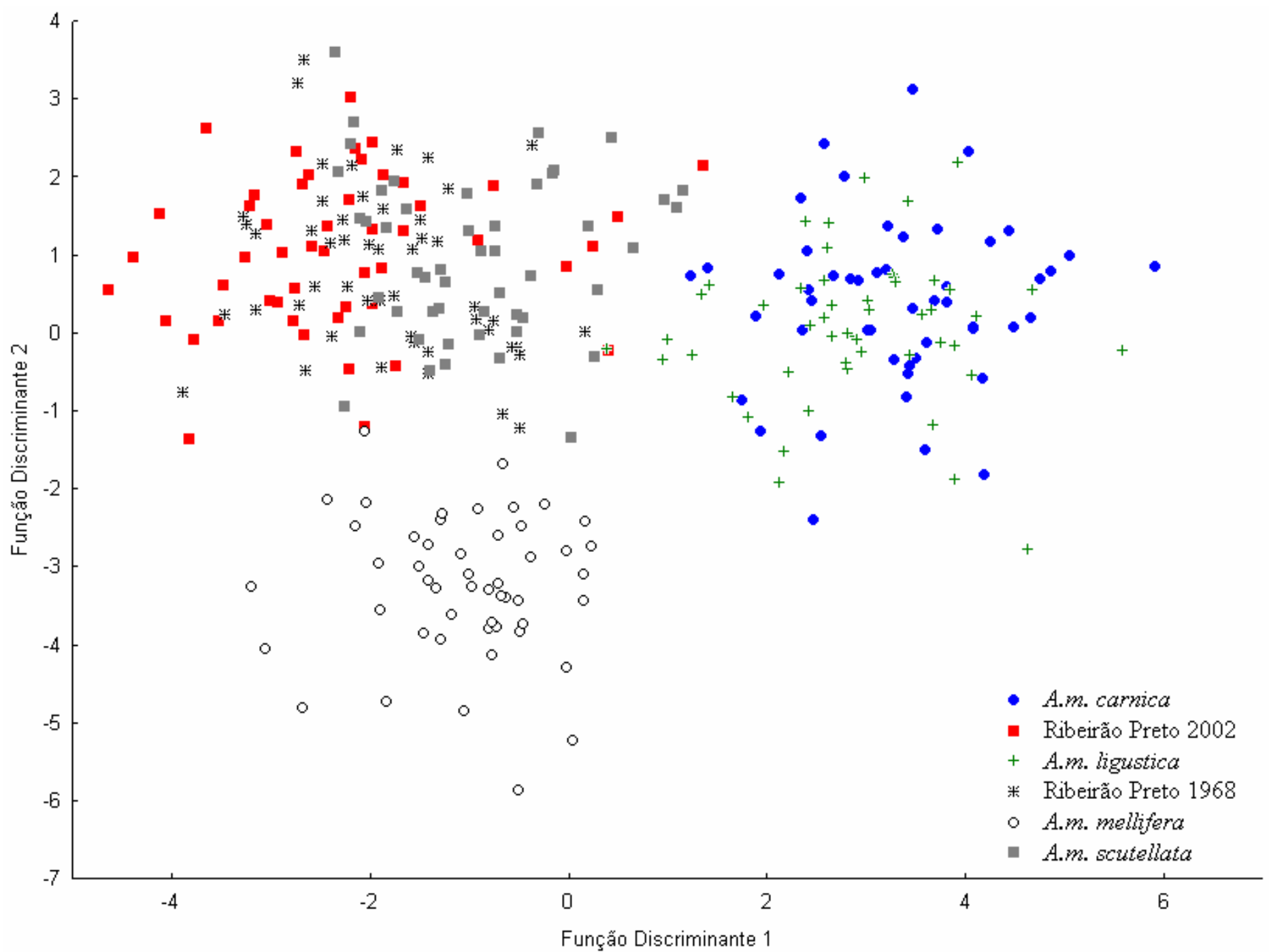

Figura 29: Análise de discriminantes canônicas das populações de abelhas africanizadas de Ribeirão Preto de 1968 e 2002 juntamente com as subespécies formadoras das abelhas africanizadas. 
As análises também foram realizadas utilizando as médias das abelhas pertencentes à mesma colônia. Assim, a separação dos grupos teve a contribuição de 12 dentre as 34 deformações relativas geradas $(\mathrm{P}<0,05)$. A MANOVA de todas as deformações relativas acusou a presença de diferenças significantes entre os grupos (Wilk's $\lambda=0,00001 \mathrm{P}<$ 0,00001), sendo que as distâncias quadradas de Mahalanobis entre os centróides das distribuições se mostraram estatisticamente diferentes $(\mathrm{P}<0,05)$ (Tabela 23).

Tabela 23: Distâncias quadradas de Mahalanobis entre os centróides dos pares de populações. A metade superior da tabela mostra as distâncias entre os centróides e a metade inferior indica sua significância estatística.

\begin{tabular}{|c|c|c|c|c|c|c|} 
& A.m.carnica & $\mathrm{RP}-2002$ & A.m.ligustica & $\mathrm{RP}-1968$ & A.m.mellifera & A.m.scutellata \\
\hline A.m.carnica & & 327.73 & 60.32 & 252.48 & 249.30 & 162.85 \\
\hline $\mathrm{RP}-2002$ & 0.000 & & 249.27 & 66.55 & 163.34 & 164.14 \\
\hline A.m.ligustica & 0.004 & 0.000 & & 178.76 & 223.40 & 106.30 \\
\hline RP-1968 & 0.000 & 0.002 & 0.000 & & 159.57 & 82.39 \\
\hline A.m.mellifera & 0.000 & 0.000 & 0.000 & 0.000 & & 212.52 \\
\hline A.m.scutellata & 0.000 & 0.000 & 0.000 & 0.000 & 0.000 & \\
\hline
\end{tabular}

A partir das distâncias de Mahalanobis foi construído um dendograma de proximidade morfológica (Figura 30) no qual a disposição dos grupos é idêntica à disposição da abordagem anterior (Figura 28), sendo que a única diferença é a escala das distâncias.

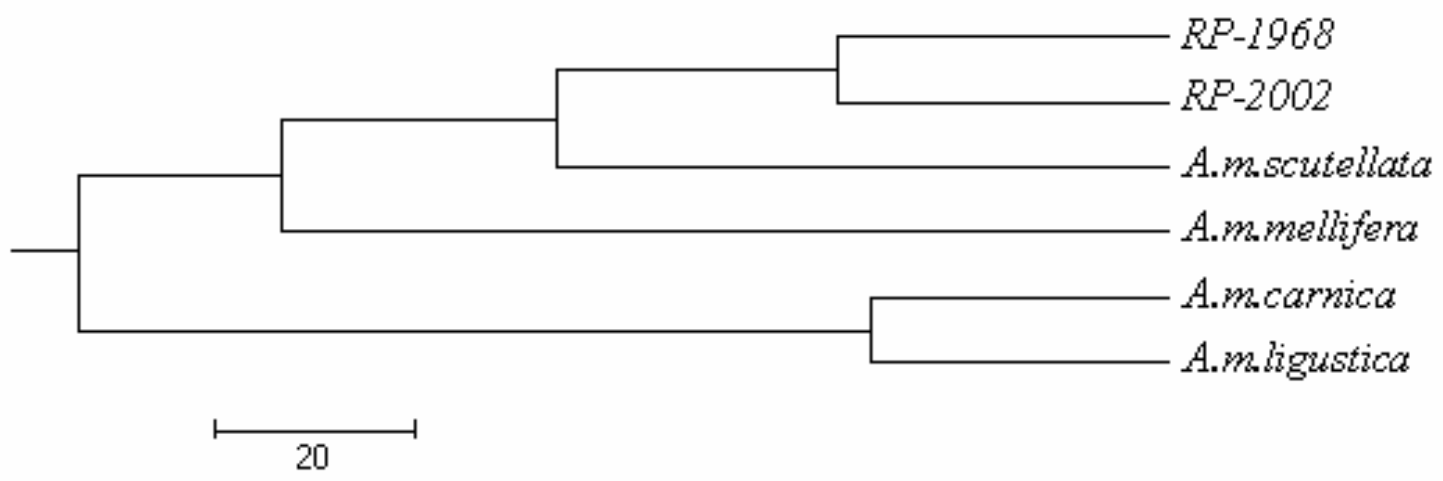

Figura 30: Dendograma de proximidade morfológica construído a partir das distâncias quadradas de Mahalanobis entre os pares de populações calculadas por análises de deformações relativas obtidas das colônias dos grupos.

As equações discriminantes foram capazes de classificar 100\% das colônias dentro de seus respectivos grupos (Tabela 24) e 81,7\% foram corretamente identificadas nos testes de validação cruzada (Tabela 25). 
Tabela 24: Classificação das colônias dentro de seus respectivos grupos através das análises discriminantes. As linhas correspondem às classificações esperadas e as colunas às classificações observadas. Os valores em destaque correspondem ao número em porcentagem de colméias corretamente classificadas.

\begin{tabular}{|c|c|c|c|c|c|c|} 
& A.m.carnica & $\mathrm{RP}-2002$ & A.m.ligustica & $\mathrm{RP}-1968$ & A.m.mellifera & A.m.scutellata \\
\hline A.m.carnica & 100 & 0 & 0 & 0 & 0 & 0 \\
\hline RP-2002 & 0 & 100 & 0 & 0 & 0 & 0 \\
\hline A.m.ligustica & 0 & 0 & 100 & 0 & 0 & 0 \\
\hline RP-1968 & 0 & 0 & 0 & 100 & 0 & 0 \\
\hline A.m.mellifera & 0 & 0 & 0 & 0 & 100 & 0 \\
\hline A.m.scutellata & 0 & 0 & 0 & 0 & 0 & 100 \\
\hline
\end{tabular}

Tabela 25: Identificação de colônias dentro de seus respectivos grupos através dos testes de validação cruzada. As linhas correspondem às identificações esperadas e as colunas às identificações observadas. Os valores em destaque correspondem ao número em porcentagem de colméias corretamente identificadas.

\begin{tabular}{|c|c|c|c|c|c|c|} 
& A.m.carnica & RP-2002 & A.m.ligustica & $\mathrm{RP}-1968$ & A.m.mellifera & A.m.scutellata \\
\hline A.m.carnica & 100 & 0 & 0 & 0 & 0 & 0 \\
\hline RP-2002 & 0 & 90 & 0 & 10 & 0 & 0 \\
\hline A.m.ligustica & 20 & 0 & 80 & 0 & 0 & 0 \\
\hline RP-1968 & 0 & 20 & 0 & 40 & 20 & 20 \\
\hline A.m.mellifera & 0 & 0 & 0 & 0 & 100 & 0 \\
\hline A.m.scutellata & 0 & 0 & 0 & 20 & 0 & 80 \\
\hline
\end{tabular}

A disposição gráfica dos grupos (Figura 31) fica muito parecida com a anterior, sendo que a diferença mais marcante é a não sobreposição dos grupos de $A$. m. scutellata e as duas populações africanizadas, muito embora elas ainda formem um agrupamento distinto. Os grupos de $A$. m. ligustica e $A$. m. carnica também não ficam mais sobrepostos, mostrando uma clara delimitação entre eles. 


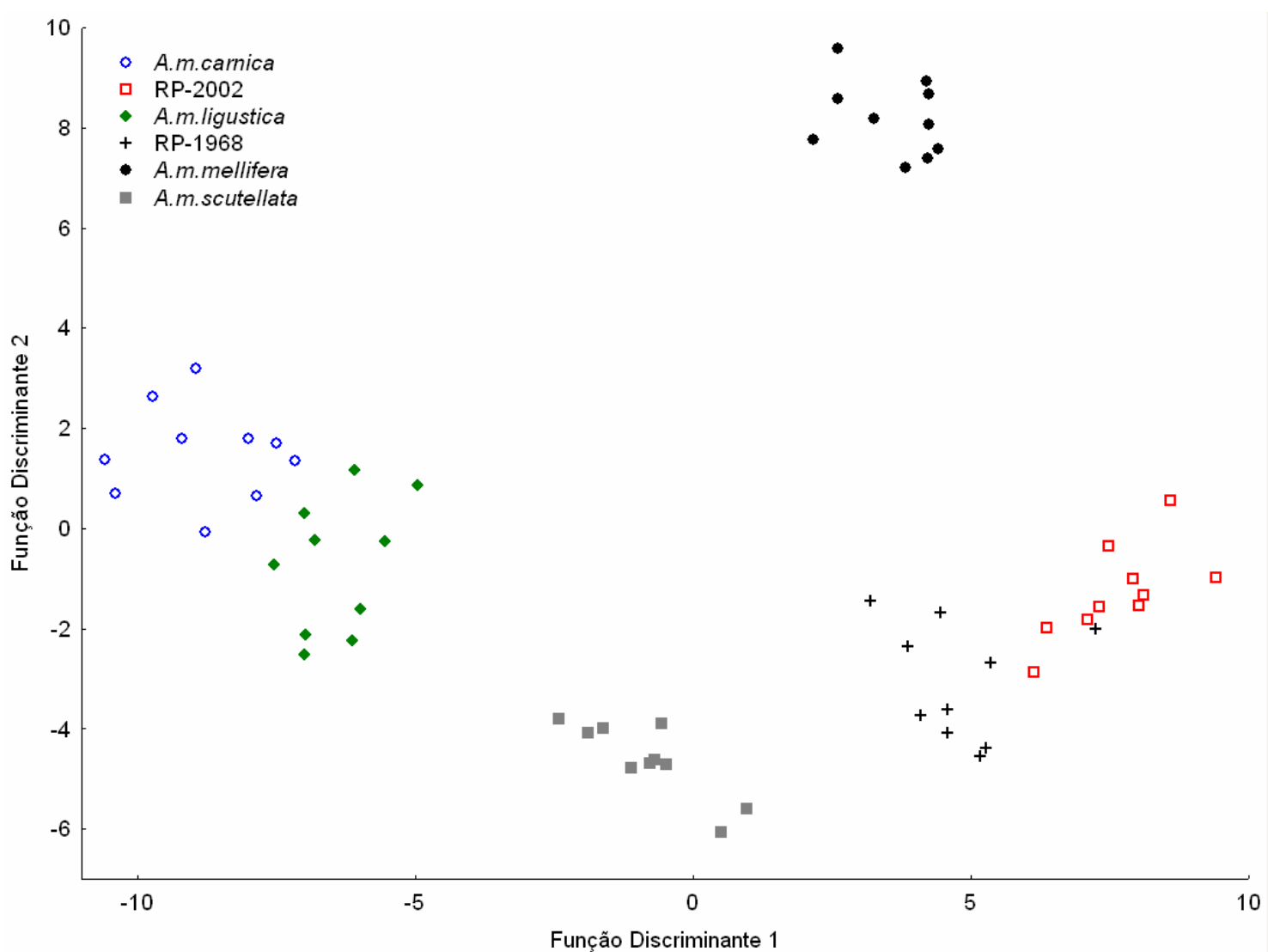

Figura 31: Análise de discriminantes canônicas dos grupos a partir das medidas de deformações relativas calculadas a partir das médias dos indivíduos de mesma colônia.

A partir das coordenadas geométricas obtidas a partir dos espécimes alinhados, foi possível realizar uma comparação de forma entre as asas das duas populações de Ribeirão Preto (Figura 32). Numa comparação visual, fica claro que os principais pontos de mudança são na região dos marcos anatômicos $1,4,6,10,17,18$ e 19, sendo que as mudanças mais pronunciadas ficam por conta dos marcos anatômicos 1, 6 e 19 . 


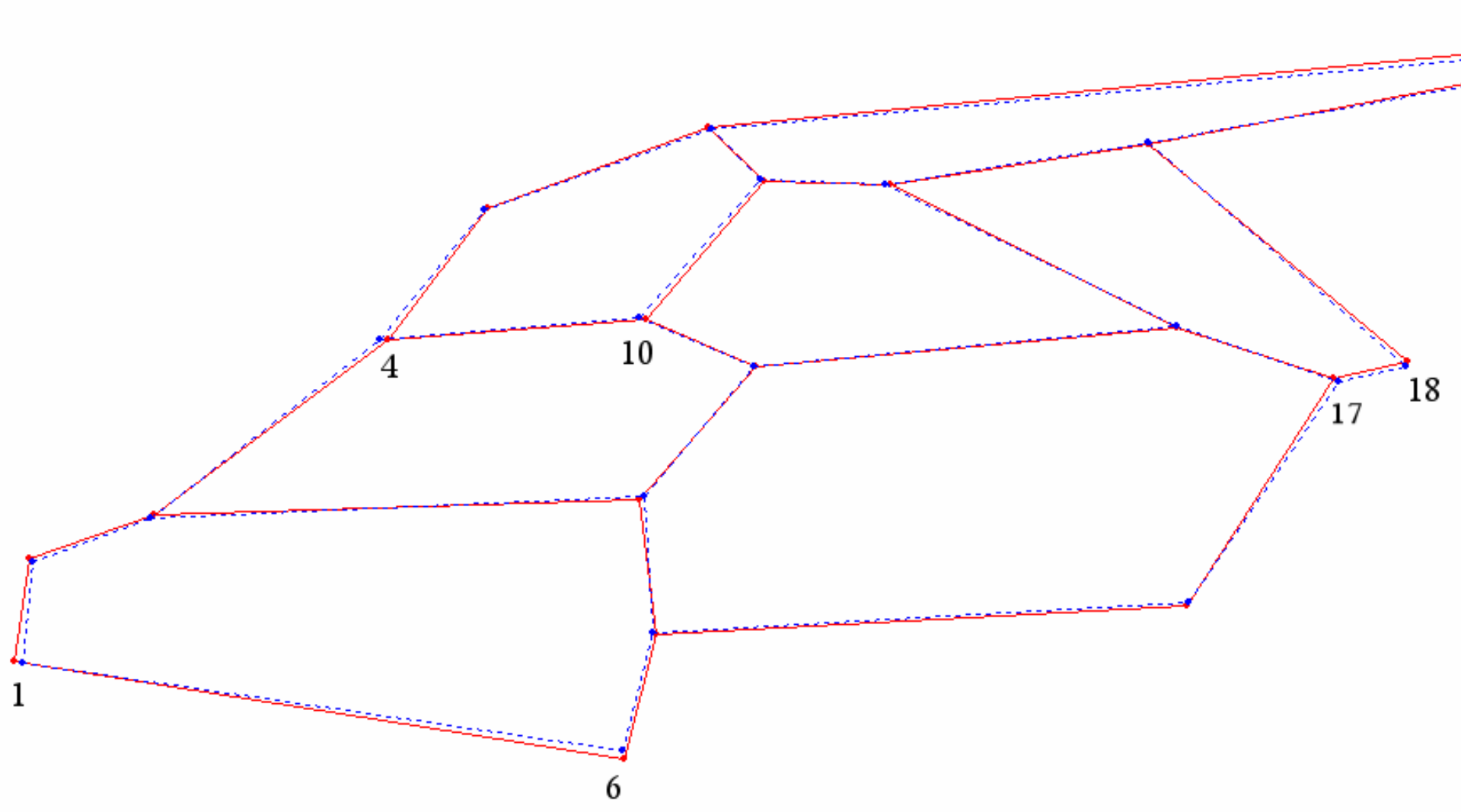

\section{RP $2002>$ RP 1968}

Figura 32: Formas médias das asas das duas populações de Ribeirão Preto. A população de 2002 é representada pela forma das linhas em azul e a população de 1968 é representada pela forma das linhas em vermelho. Em destaque estão os marcos anatômicos com maior deslocamento. 


\subsection{3 - J - ABIS.}

De acordo com as análises discriminantes lineares, 99,7\% dos indivíduos foram corretamente classificados dentro de seus respectivos grupos, sendo que destes, $85,3 \%$ e $80,9 \%$ foram corretamente identificados nos testes de validação cruzada utilizando respectivamente $10 \%$ e $20 \%$ dos indivíduos como desconhecidos. A partir das distâncias quadradas de Mahalanobis (Tabela 26) entre os pares de populações, um dendograma de proximidade morfológica (Figura 33) foi construído e apresentou uma conformação dos grupos um pouco diferente das análises com morfometria geométrica. Os grupos são separados em dois ramos, um com as abelhas africanas e as duas populações africanizadas e um outro ramo com as subespécies européias, sendo que A. m. mellifera fica mais próxima de $A$. m. ligustica do que A. m. carnica.

Tabela 26: Distâncias quadradas de Mahalanobis entre os pares de populações calculadas pelo software ABIS a partir de análises discriminantes lineares.

\begin{tabular}{|c|c|c|c|c|c|} 
& A.m.ligustica & A.m.carnica & A.m.scutellata & $\mathrm{RP}-1968$ & $\mathrm{RP}-2002$ \\
\hline A.m.mellfera & 2.32 & 2.29 & 2.12 & 2.16 & 2.34 \\
\hline A.m.ligustica & & 2.31 & 2.27 & 2.31 & 2.45 \\
\hline A.m.carnica & & & 2.19 & 2.24 & 2.44 \\
\hline A.m.scutellata & & & & 2.09 & 2.24 \\
\hline RP-1968 & & & & & 2.23 \\
\hline
\end{tabular}

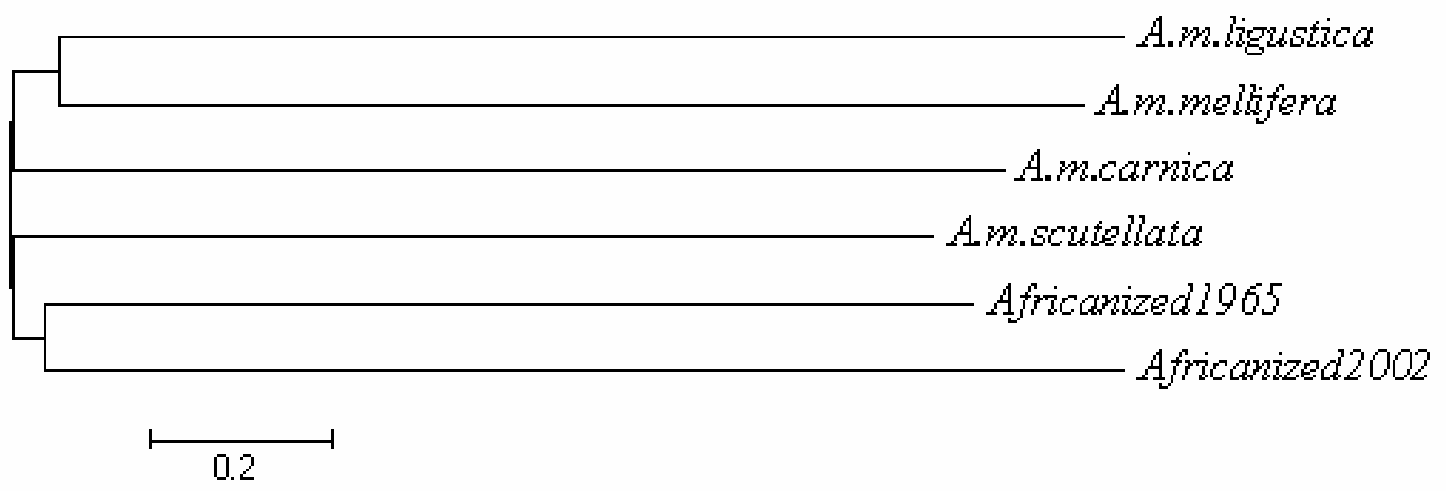

Figura 33: Dendograma de proximidade morfológica construído a partir das distâncias quadradas de Mahalanobis entre os pares de populações de acordo com análises discriminantes lineares. 
A representação gráfica das análises discriminantes (Figura 34) mostra uma grande diferença entre os grupos de abelhas africanizadas e os demais grupos, sendo que $A$. $m$. scutellata e $A$. m. mellifera ficam mais isolados enquanto $A$. m. ligustica e $A$. m. carnica ficam mais próximas. 
KEY ( 6 ol asses〉

mell ifera

ligustica

Gornica

soutel lata

africanizada ribei rao 1968

africanizada ribei rao 2002

* Center

- Training Sample

+ Test Sample

-Unknown Sample

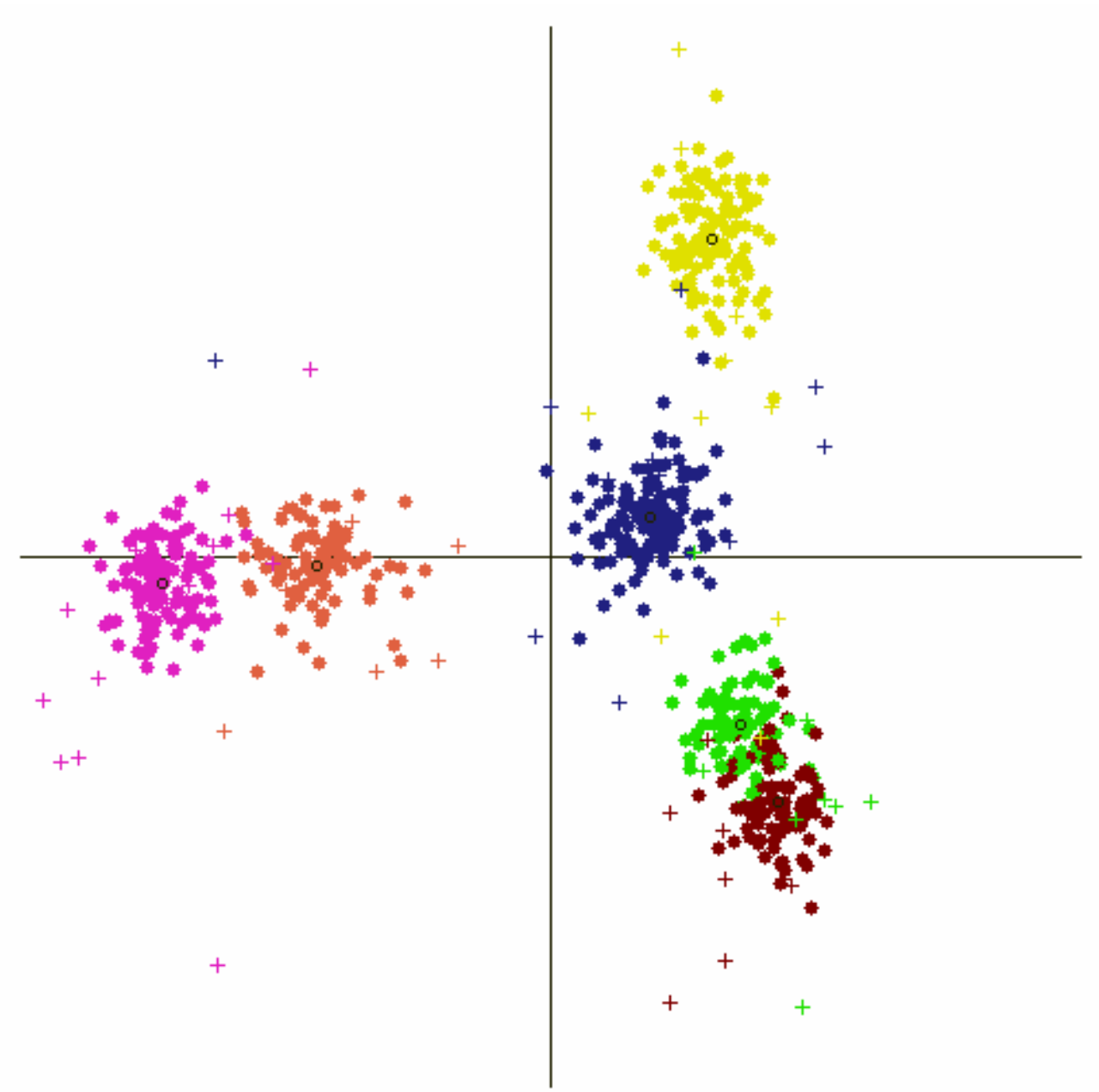

Figura 34: Representação gráfica da análise discriminante linear (LDA) realizada pelo ABIS mostrando os seis grupos estudados. 
Já as análises discriminantes com funções não lineares de Kernel foram capazes de distinguir $100 \%$ dos indivíduos dentro de seus respectivos grupos, sendo que $92,6 \%$ e $92 \%$ de identificações corretas foram obtidas com respectivamente $10 \%$ e $20 \%$ dos indivíduos utilizados como desconhecidos nos testes de validação cruzada. Quando comparadas com as distâncias quadradas de Mahalanobis geradas pelas análises lineares, as atuais são muito maiores (Tabela 27) e o dendograma de proximidade morfológica construído a partir destas distâncias (Figura 35) também se mostra diferente do anterior. Este também se mostra dividido em dois ramos, entretanto com algumas mudanças. Nele, A. m. ligustica e A. m. carnica ficam agrupadas, seguidas de $A$. m mellifera e por $A$. $m$. scutellata que muda de ramo em relação à topologia anterior. No outro ramo ficam as duas populações de abelhas africanizadas de Ribeirão Preto

Tabela 27: Distâncias quadradas de Mahalanobis entre os centróides das distribuições dos grupos calculados pelo software ABIS a partir de análises discriminantes não lineares.

\begin{tabular}{|c|c|c|c|c|c|} 
& A.m.ligustica & A.m.carnica & A.m.scutellata & $\mathrm{RP}-1968$ & $\mathrm{RP}-2002$ \\
\hline A.m.melifera & 12.45 & 12.37 & 11.63 & 21.78 & 18.42 \\
\hline A.m.ligustica & & 8.68 & 12.81 & 21.75 & 18.00 \\
\hline A.m.carnica & & & 13.16 & 22.35 & 18.85 \\
\hline A.m.scutellata & & & & 19.80 & 15.43 \\
\hline RP-1968 & & & & & 12.51 \\
\hline
\end{tabular}

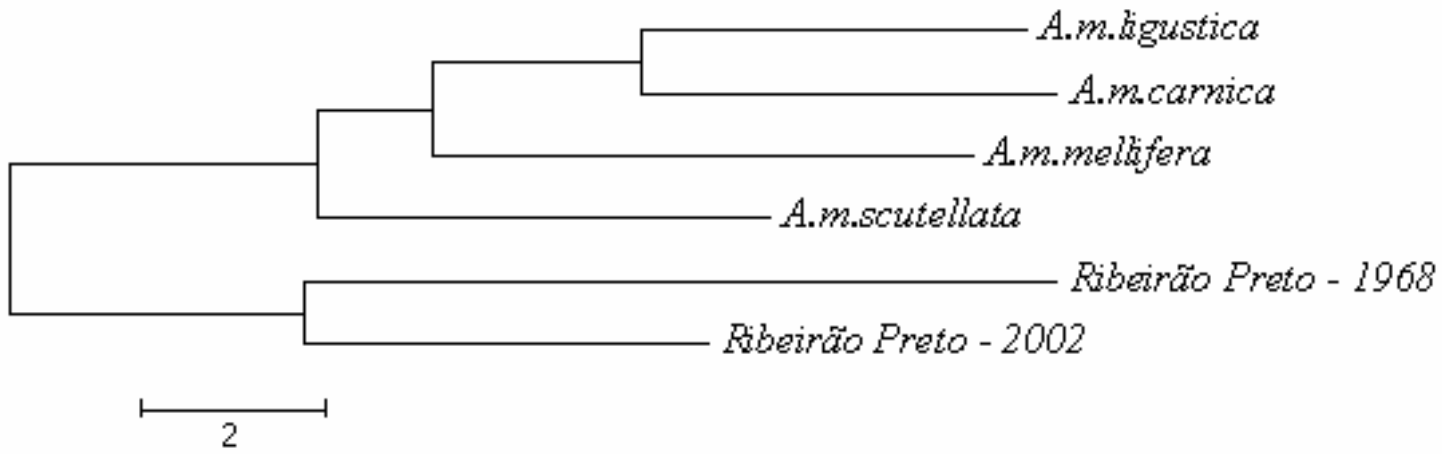

Figura 35: Dendograma de proximidade morfológica entre os grupos estudados construído a partir das distâncias quadradas de Mahalanobis entre os pares de populações.

A representação gráfica das análises discriminantes não lineares (Figura 36) apresenta todos os grupos bem definidos, com sobreposição somente de $A$. m. ligustica com A. m. carnica. 
KEY ( 6 ol asses)

melli fera

1 i gustica

Garnica

Ecutel lata

africanizada ribei nao1968

africanizada ribei rao2002

* Center

- Training Sample

+ Test Sample

-Unknown Sample

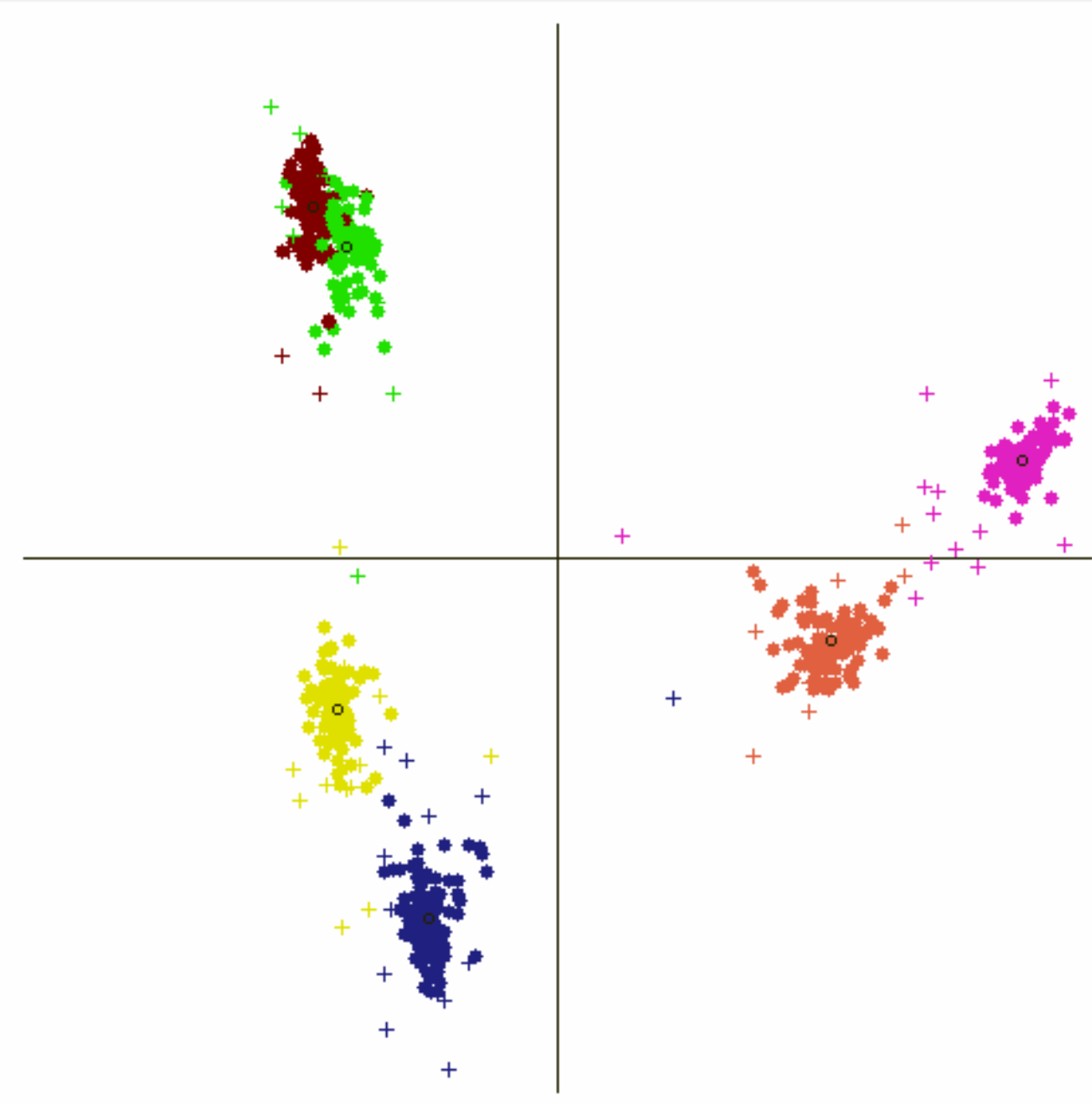

Figura 36: Representação gráfica dos grupos após classificação por análises discriminantes não lineares (KDA) realizadas pelo software ABIS. 


\subsection{4 - DNA Mitocondrial.}

Amostras das mesmas 25 colônias que estão em nosso poder também foram enviadas para o Laboratório de Genética e Evolução de Abelhas do Instituto de Biociências da USP, onde nove colônias já haviam tido seu DNA mitocondrial identificado quanto a sua origem (Arias et al., não publicado). Desta maneira, nossos esforços foram concentrados nas 16 colônias restantes. Uma vez que tais abelhas se encontram conservadas a seco, o DNA contido nestas amostras estava bastante degradado. Assim sendo, somente foi obtido DNA com integridade suficiente para que a origem materna de mais nove colônias pudesse ser identificada.

Das nove colônias que tiveram sua origem materna identificada por Arias et al (dados não publicados), cinco apresentaram DNA mitocondrial de origem européias e quatro apresentaram origem africana. Já nas outras nove colônias que foram identificadas neste trabalho, sete apresentaram DNA mitocondrial de origem africana e duas apresentaram sítio de restrição no fragmento amplificado, indicando origem européia. No total, para a amostra de 1968, 11 colônias apresentaram origem materna africana e sete apresentaram origem européia, ou $61 \%$ e $39 \%$ respectivamente.

Já nas 18 colônias amostradas no ano de 2002 não foi encontrado nenhum DNA mitocondrial de origem européia, indicando uma completa substituição dos mitótipos europeus por africanos.

\section{3 - Mudanças na população do Panamá entre os anos de 1982 e 2006.}

\subsection{1 - Morfometria tradicional.}

Assim como feito anteriormente, as $A$. $m$. scutellata foram utilizadas como fator de comparação entre os grupos, uma vez que é a subespécie que mais influencia as abelhas africanizadas de uma maneira geral. A população de abelhas africanizadas do Panamá de 1982, que representa o início do processo de africanização naquele país, apresentou as medidas de comprimento da asa anterior e comprimento da célula radial maior que os 
outros dois grupos $(\mathrm{P}<0,05)$. A medida de largura da asa anterior não foi estatisticamente diferente entre as três amostras e o comprimento da célula radial também não apresenta diferenças quando comparamos os grupos de $A$. m. scutellata e a população de 2006 (Tabela 28). Mesmo que diferenças significantes não tenham sido encontradas entre algumas das amostras analisadas, as medidas realizadas seguem o mesmo padrão das mudanças temporais na cidade de Ribeirão Preto - SP, onde as abelhas do princípio do processo de africanização são, de uma maneira geral, maiores, as $A$. m. scutellata apresentam-se intermediárias aos dois tipos e as abelhas atuais apresentam as menores médias dos três grupos.

Tabela 28: Medidas de morfometria tradicional nas duas populações Panamenhas coletadas nos anos de 1982 e 2006 , bem como nas $A$. m. scutellata. CA = comprimento da asa anterior, LA = largura da asa anterior e $\mathrm{CR}=$ comprimento da célula radial. Letras iguais na mesma coluna indicam ausência de diferenças estatísticas e letras diferentes indicam presença de diferença estatística $(\mathrm{P}=0,05)$

\begin{tabular}{|c|c|c|c|c|} 
& CA & LA & CR & $\mathrm{N}$ \\
\hline Panamá 1982 & $0.856 \pm 0.02^{\mathrm{a}}$ & $0.303 \pm 0.008^{\mathrm{a}}$ & $0.317 \pm 0.009^{\mathrm{b}}$ & 48 \\
\hline Panamá 2006 & $0.830 \pm 0.02^{\mathrm{b}}$ & $0.292 \pm 0.008^{\mathrm{b}}$ & $0.306 \pm 0.008^{\mathrm{a}}$ & 50 \\
\hline A.mscutellata & $0.844 \pm 0.010^{\mathrm{c}}$ & $0.301 \pm 0.011^{\mathrm{a}}$ & $0.309 \pm 0.012^{\mathrm{a}}$ & 50 \\
\hline
\end{tabular}

\subsection{2 - Morfometria Geométrica.}

Como tínhamos como um dos objetivos deste trabalho testar as novas metodologias morfométricas na tarefa de discriminar grupos de abelhas e também estabelecer protocolos que melhor apresentem os resultados, esta análise também foi feita utilizando as medidas dos indivíduos e as médias de indivíduos de mesma colônia, com a diferença de que nesta parte do trabalho, foram utilizados 10 indivíduos por colônias de cada uma das subespécies ao invés de cinco. O número original de cinco asas por colônia foi mantido apenas para as populações panamenhas, uma vez que não dispúnhamos de mais exemplares destas amostras. O número de individuos foi testado visando estabelecer um número adequado de indivíduos que deve ser amostrado por colônia. 
Quando da utilização das medidas extraídas dos indivíduos nas análises, 33 das 34 deformações relativas contribuíram significantemente $(\mathrm{P}<0,05)$ para a separação dos seis grupos estudados (A. m. mellifera, A. m. ligustica, A. m. carnica, A. m. scutellata, a população do Panamá de 1982 e de 2006) enquanto a MANOVA com as 34 características evidenciou a presença de diferenças significantes entre os grupos (Wilk's $\lambda=0,0109 \mathrm{P}<0,0001$ ). Todas as distâncias quadradas de Mahalanobis entre os centróides das distribuições (Tabela 29) apresentaram diferenças estatísticas significantes $(\mathrm{P}=0,05)$.

Tabela 29: Distâncias quadradas de Mahalanobis entre os centróides das distribuições dos grupos de abelhas do Panamá e das subespécies formadoras das abelhas africanizadas. A metade superior da tabela mostra as distâncias entre os centróides e a metade inferior mostra a respectiva significância estatística

\begin{tabular}{|c|c|c|c|c|c|c|} 
& A.m.ligustica & A.m.carnica & A.m.mellifera & A.m.scutellata & Panamá 1982 & Panamá 2006 \\
\hline A.m.ligustica & & 7.55 & 32.55 & 28.85 & 28.90 & 36.57 \\
\hline A.m.carnica & 0.001 & & 40.68 & 28.13 & 27.60 & 38.79 \\
\hline A.m.mellfera & 0.001 & 0.001 & & 24.52 & 26.33 & 31.46 \\
\hline A.m.scutellata & 0.001 & 0.001 & 0.001 & & 7.73 & 9.28 \\
\hline Panamá 1982 & 0.001 & 0.001 & 0.001 & 0.001 & & 3.50 \\
\hline Panamá 2006 & 0.001 & 0.001 & 0.001 & 0.001 & 0.001 & \\
\hline
\end{tabular}

A partir destas distâncias de Mahalanobis foi construído um dendograma de proximidade morfológica (Figura 37) que se assemelha muito ao construído na comparação das populações de abelhas de Ribeirão Preto - SP de 1968 e 2002, sendo que o posicionamento das populações do Panamá é o mesmo, e a população atual é mais distante das A. m. scutellata que a população de 1982. A única diferença entre os dois dendogramas está na magnitude das distâncias entre os grupos. 


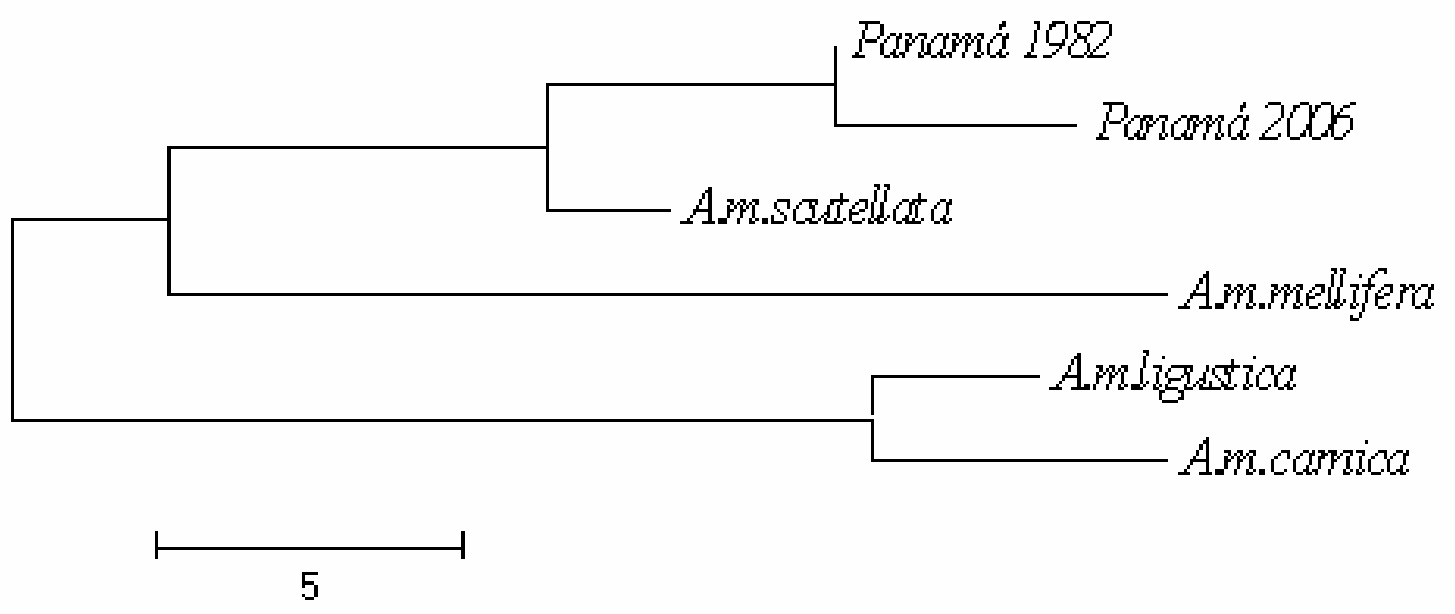

Figura 37: Dendograma de proximidade morfológica entre as subespécies de $A$. mellifera e as populações de abelhas do Panamá de 1982 e 2006 construído a partir das distâncias quadradas de Mahalanobis entre os grupos.

As funções discriminantes foram capazes de classificar 90,3\% dos indivíduos dentro de seus respectivos grupos (Tabela 30) e 84,5\% dos indivíduos foram corretamente identificados nos testes de validação cruzada (Tabela 31).

Tabela 30: Classificação dos indivíduos das amostras estudadas dentro de seus respectivos grupos através das análises discriminantes. As linhas correspondem às classificações esperadas e as colunas às classificações observadas. Os valores em destaque correspondem ao número em porcentagem de indivíduos corretamente classificados.

\begin{tabular}{|c|c|c|c|c|c|c|}
\hline & A.m.ligustica & A.m.carnica & A.m.mellifera & A.m.scutellata & Panamá 1982 & Panamá 2006 \\
\hline A.m.ligustica & 92.8 & 6.2 & 0.0 & 0.0 & 0.0 & 1.0 \\
\hline A.m.carnica & 6.0 & 94.0 & 0.0 & 0.0 & 0.0 & 0.0 \\
\hline A.m.mellifera & 0.7 & 0.0 & 99.3 & 0.0 & 0.0 & 0.0 \\
\hline A.m.scutellata & 0.7 & 0.0 & 0.0 & 92.1 & 5.0 & 2.1 \\
\hline Panamá 1982 & 2.0 & 4.0 & 0.0 & 18.0 & 56.0 & 20.0 \\
\hline Panamá 2006 & 0.0 & 0.0 & 0.0 & 12.0 & 12.0 & 76.0 \\
\hline
\end{tabular}

Tabela 31: Identificação de indivíduos das amostras estudadas dentro de seus respectivos grupos através dos testes de validação cruzada. As linhas correspondem às identificações esperadas e as colunas às identificações observadas. Os valores em destaque correspondem ao número em porcentagem de indivíduos corretamente identificados.

\begin{tabular}{|l|c|c|c|c|c|c|} 
& A.m.ligustica & A.m.carnica & A.m.mellifera & A.m.scutellata & Panamá 1982 & Panamá 2006 \\
\hline A.m.ligustica & 84.5 & 13.4 & 0.0 & 1.0 & 0.0 & 1.0 \\
\hline A.m.carnica & 6.0 & 94.0 & 0.0 & 0.0 & 0.0 & 0.0 \\
\hline A.m.mellifera & 1.3 & 0.0 & 98.7 & 0.0 & 0.0 & 0.0 \\
\hline A.m.scutellata & 0.7 & 0.0 & 1.4 & 85.7 & 5.7 & 6.4 \\
\hline Panamá 1982 & 2.0 & 6.0 & 2.0 & 20.0 & 42.0 & 28.0 \\
\hline Panamá 2006 & 0.0 & 0.0 & 2.0 & 20.0 & 26.0 & 52.0 \\
\hline
\end{tabular}

A distribuição gráfica dos grupos na análise discriminante (Figura 38) também é extremamente similar àquela apresentada na comparação temporal dos grupos de Ribeirão 
Preto (Figura 29). As populações do Panamá e A. m. scutellata formam um grupo distinto, e as subespécies européias ficam agrupadas em dois outros grupos, $\operatorname{com} A$. m. ligustica e $A . m$. carnica em um cluster e A. m. mellifera num cluster isolado. 


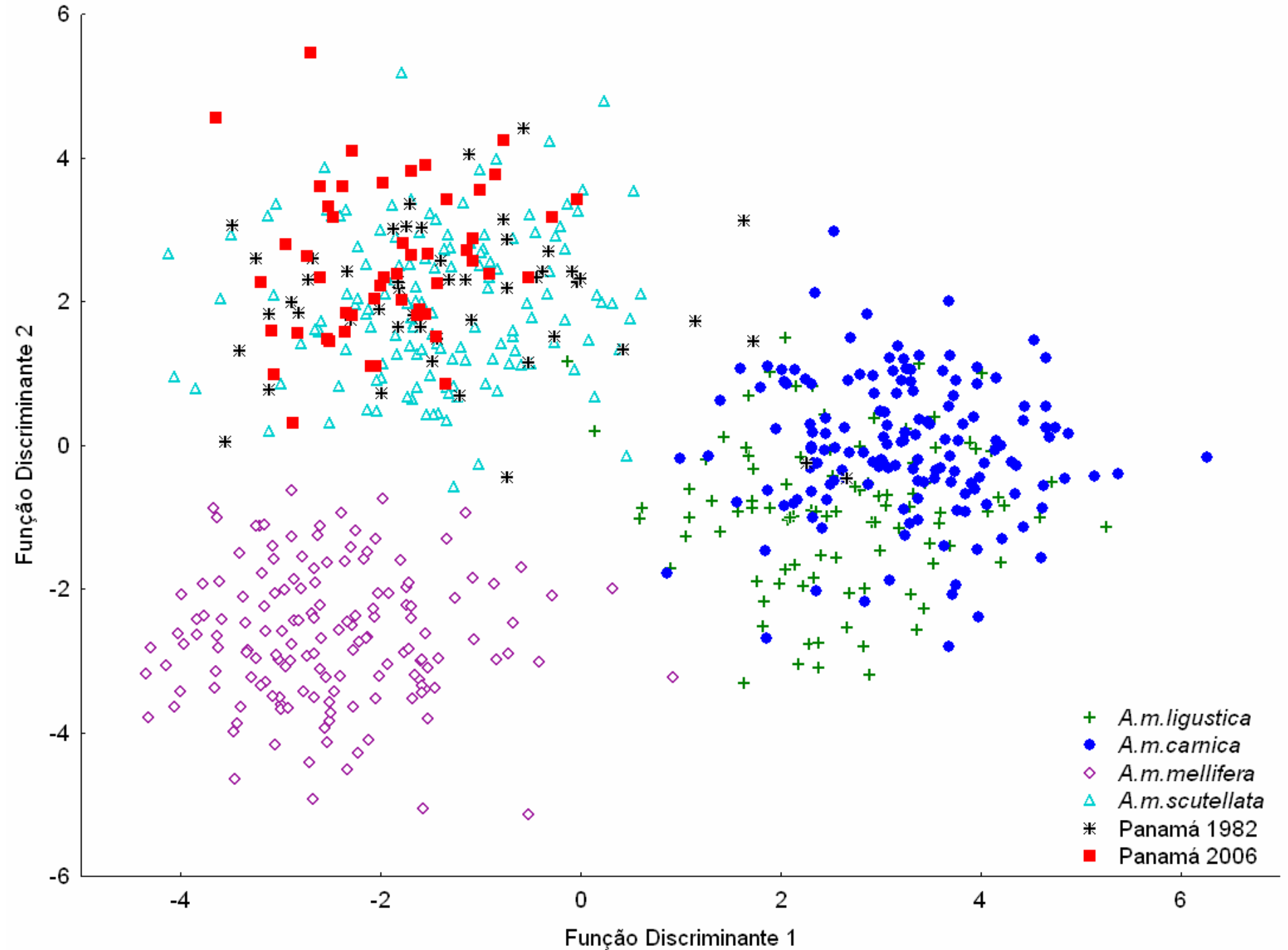

Figura 38: Análise de discriminantes canônicas das populações estudadas de abelhas africanizadas do Panamá e das subespécies de Apis mellifera. 
A análise seguinte foi realizada utilizando as médias de indivíduos de mesma colônia como base de dados para as análises. Dentre as 34 deformações relativas geradas pelas análises, 16 contribuíram significativamente $(\mathrm{P}<0,05)$ para a separação dos grupos. A MANOVA com as 34 medidas de deformações relativas revelou a presença de diferenças estatísticas significantes entre os grupos (Wilk's $\lambda=0,00002 \mathrm{P}<0,00001$ ). As distâncias quadradas de Mahalanobis entre os centróides das distribuições (Tabela 32) se mostraram estatisticamente diferentes para todos os grupos $(\mathrm{P}<0,05)$ exceto para os dois grupos panamenhos.

Tabela 32: Distâncias quadradas de Mahalanobis entre os centróides dos pares de populações. A metade superior da tabela indica os valores das distâncias de Mahalanobis e a metade inferior indica a significância estatística das mesmas.

\begin{tabular}{|c|c|c|c|c|c|c|} 
& Panamá 2006 & Panamá 1982 & A.m.scutellata & A.m.carnica & A.m.mellifera & A.m.ligustica \\
\hline Panamá 2006 & & 19.68 & 56.08 & 188.38 & 214.55 & 232.07 \\
\hline Panamá 1982 & 0.2 & & 62.87 & 167.75 & 207.85 & 240.57 \\
\hline A.m.scutellata & 0.001 & 0.001 & & 117.98 & 139.94 & 161.08 \\
\hline A.m.carnica & 0.001 & 0.001 & 0.001 & & 250.25 & 54.72 \\
\hline A.m.mellifera & 0.001 & 0.001 & 0.001 & 0.001 & & 242.88 \\
\hline A.m.ligustica & 0.001 & 0.001 & 0.001 & 0.001 & 0.001 & \\
\hline
\end{tabular}

A partir destas distâncias quadradas de Mahalanobis, foi construído um dendograma de proximidade morfológica (Figura 39). Assim como nas outras análises, as posições dos grupos permanecem inalteradas, sendo que a diferença entre os dois dendogramas fica concentrada nas distâncias entre os grupos. Novamente as $A$. m. ligustica e as $A$. m. carnica ficam agrupadas em um ramo separado. A. m. mellifera fica mais próxima das subespécies do ramo A (Ruttner, 1988) e as duas populações do Panamá ficam agrupadas juntamente com $A$. m. scutellata. 


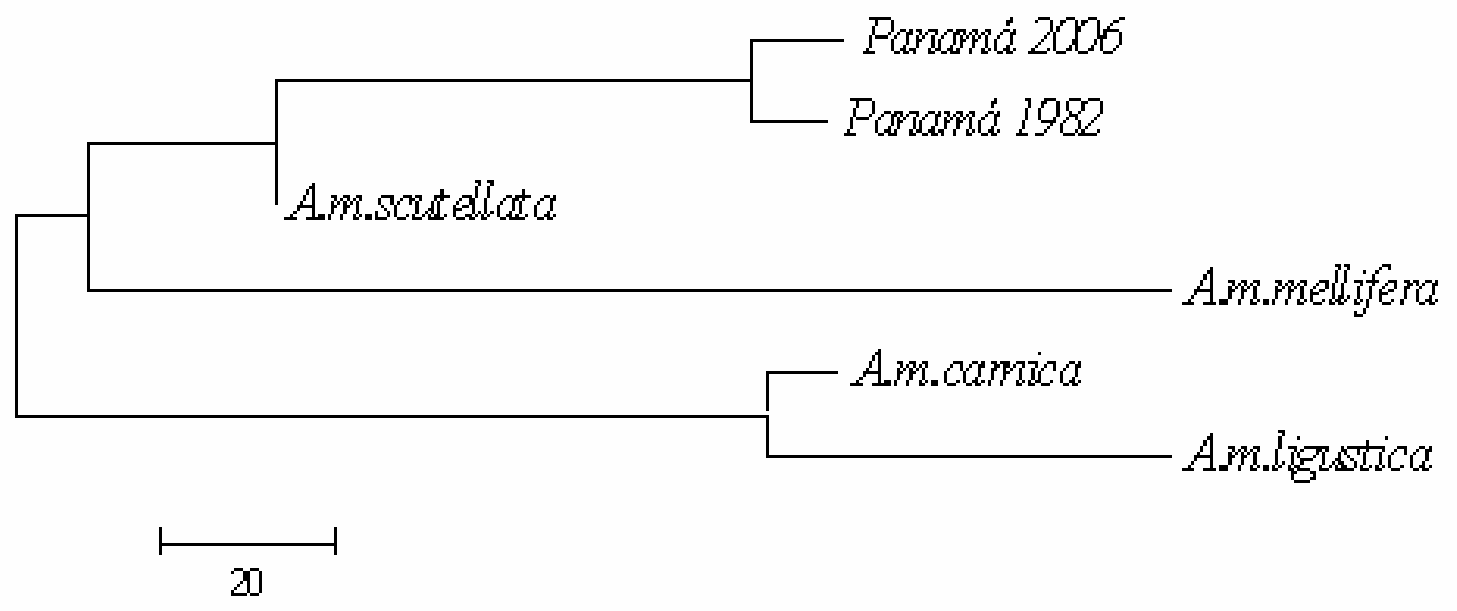

Figura 39: Dendograma de proximidade morfológica entre as populações do Panamá de 1982 e 2006 e as principais subespécies formadoras das abelhas africanizadas construído a partir das distâncias de Mahalanobis entre os grupos calculadas por análise de deformações relativas.

As funções discriminantes geradas a partir das medidas de deformações relativas foram capazes de classificar $100 \%$ das colméias dentro de seus respectivos grupos (Tabela 33) e $81,1 \%$ das colméias foram identificadas corretamente nos testes de validação cruzada (Tabela 34).

Tabela 33: Classificação das colônias dos diferentes grupos de acordo com as análises discriminantes geradas a partir das análises de deformações relativas. Os valores em destaque indicam os valores em porcentagem de colméias corretamente classificadas dentro de seus respectivos grupos.

\begin{tabular}{|l|c|c|c|c|c|c|} 
& A.m.ligustica & A.m.carnica & A.m.melljera & A.m.scutellata & Panamá 1982 & Panamá 2006 \\
\hline A.m.ligustica & 100 & 0 & 0 & 0 & 0 & 0 \\
\hline A.m.carnica & 0 & 100 & 0 & 0 & 0 & 0 \\
\hline A.m.mellifera & 0 & 0 & 100 & 0 & 0 & 0 \\
\hline A.m.scutellata & 0 & 0 & 0 & 100 & 0 & 0 \\
\hline Panamá 1982 & 0 & 0 & 0 & 0 & 100 & 0 \\
\hline Panamá 2006 & 0 & 0 & 0 & 0 & 0 & 100 \\
\hline
\end{tabular}

Tabela 34: Identificação de colônias dos diferentes grupos nos testes de validação cruzada. Os valores em destaque indicam os valores em porcentagem de colméias corretamente identificadas.

\begin{tabular}{|c|c|c|c|c|c|c|}
\hline & A.m.ligustica & A.m.carnica & A.m.mellifera & A.m.scutellata & Panamá 1982 & Panamá 2006 \\
\hline A.m.ligustica & 100.0 & 0.0 & 0.0 & 0.0 & 0.0 & 0.0 \\
\hline A.m.carnica & 6.7 & 93.3 & 0.0 & 0.0 & 0.0 & 0.0 \\
\hline A.m.mellfera & 0.0 & 0.0 & 100.0 & 0.0 & 0.0 & 0.0 \\
\hline A.m.scutellata & 0.0 & 0.0 & 0.0 & 85.7 & 7.1 & 7.1 \\
\hline Panamá 1982 & 0.0 & 10.0 & 0.0 & 10.0 & 20.0 & 60.0 \\
\hline Panamá 2006 & 0.0 & 0.0 & 0.0 & 10.0 & 20.0 & 70.0 \\
\hline
\end{tabular}

A distribuição gráfica dos grupos de acordo com as análises discriminantes (Figura 40) mostrou três clusters distintos de pontos. Um deles com A. m. ligustica e A. m. carnica, 
outro com A. m. mellifera e um terceiro com A. m. scutellata e as duas populações panamenhas. Os dois grupos do Panamá mostram grande proximidade e sobreposição.

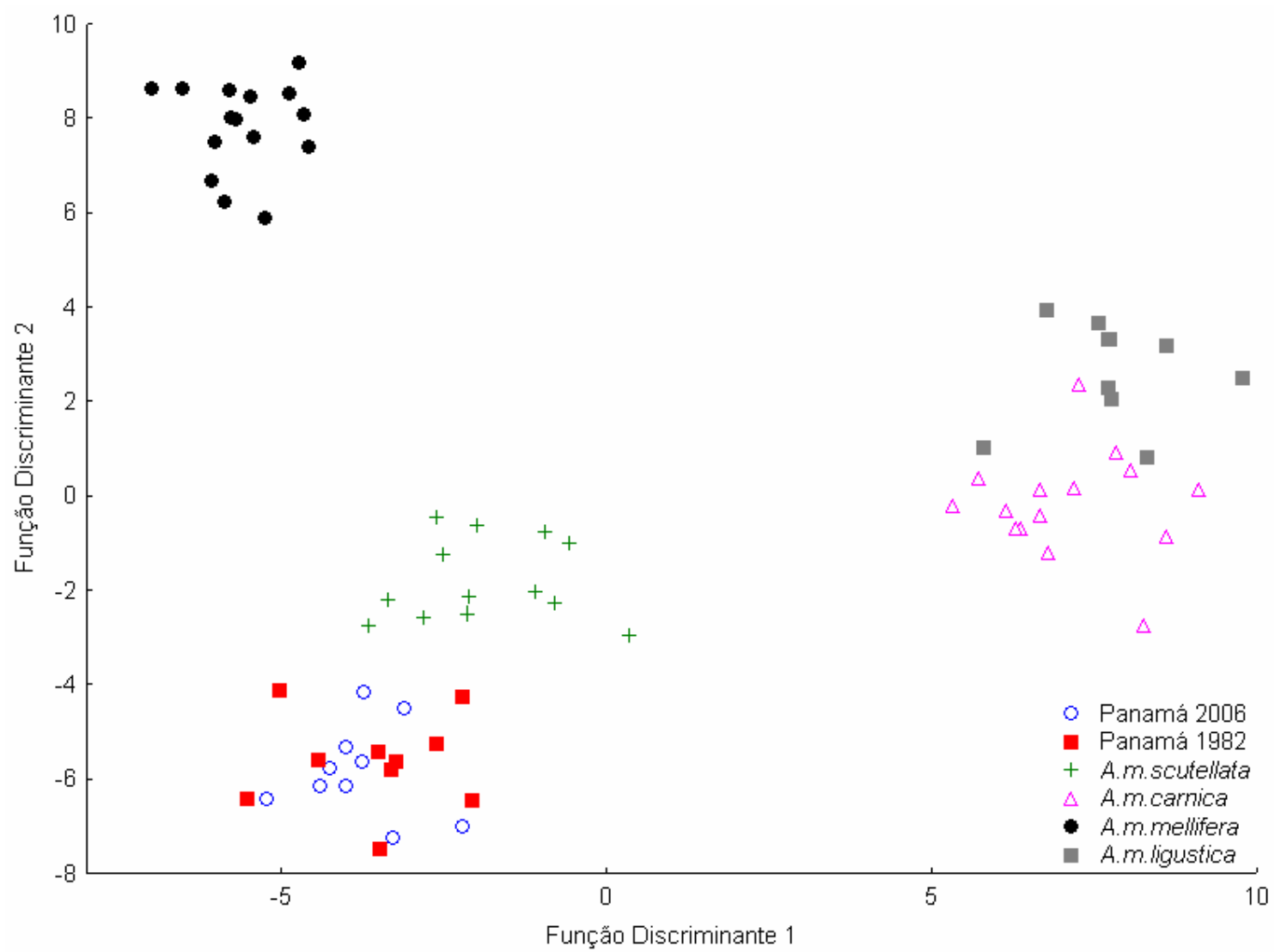

Figura 40: Representação gráfica dos grupos de acordo com as análises discriminantes canônicas geradas a partir das medidas de deformações relativas das colônias dos diferentes grupos.

A comparação das reconstruções gráficas do formato médio das asas das duas populações (Figura 41) mostra que somente diferenças mínimas existem entre os dois grupos e estão localizadas nos marcos anatômicos $1,9,14,15$ e 16, sendo que a diferença mais pronunciada é na região do marco anatômico 15 . 


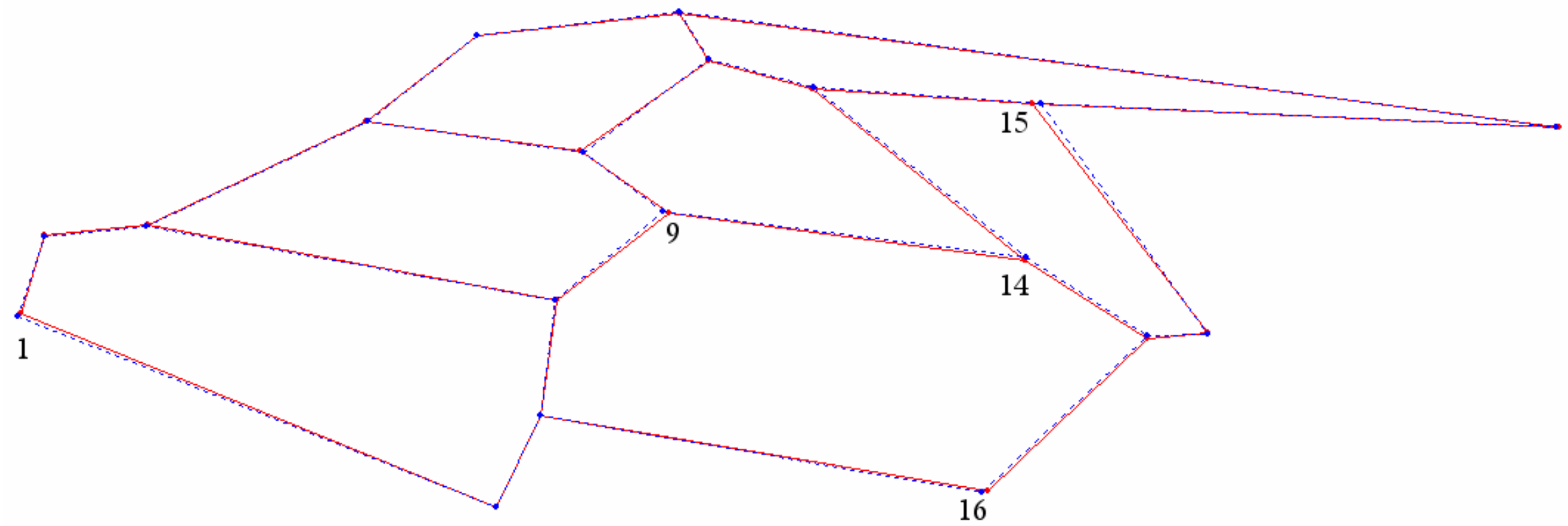

\section{$2006-1982$}

Figura 41: Formas médias das asas das duas populações do Panamá. A forma em azul com linhas pontilhadas representa a população de 2006 e a forma com linhas vermelhas sólidas representa a população de 1982. Em destaque os marcos anatômicos com maior variação entre as duas formas. 


\subsection{3 - JABIS.}

As análises discriminantes lineares foram capazes de classificar $100 \%$ dos indivíduos dentro de seus respectivos grupos, sendo que $59,2 \%$ e $30 \%$ de acerto foram os índices obtidos nos testes de validação cruzada com respectivamente $10 \%$ e $20 \%$ de indivíduos utilizados como desconhecidos nos testes de validação cruzada. A partir das distâncias quadradas de Mahalanobis entre os pares de populações (Tabela 35) foi construído um dendograma de proximidade morfológica entre os grupos (Figura 42) onde os dois grupos de abelhas panamenhas ficam na base do dendograma, com as subespécies formadoras das abelhas africanizadas ficando todas agrupadas na seqüência.

Tabela 35: Distâncias quadradas de Mahalanobis entre os pares de populações de abelhas do Panamá estudadas calculadas a partir de análises discriminantes lineares (LDA) pelo software ABIS.

\begin{tabular}{|l|c|c|c|c|c|} 
& Panamá 2006 & A.m.ligustica & A.m.carnica & A.m.mellifera & A.m.scutellata \\
\hline Panamá 1982 & 5.60 & 5.00 & 4.94 & 5.56 & 4.94 \\
\hline Panamá 2006 & & 4.98 & 4.87 & 5.52 & 4.88 \\
\hline A.m.ligustica & & & 4.09 & 4.85 & 4.13 \\
\hline A.m.carnica & & & & 4.79 & 4.04 \\
\hline A.m.mellifera & & & & 4.79 \\
\hline
\end{tabular}

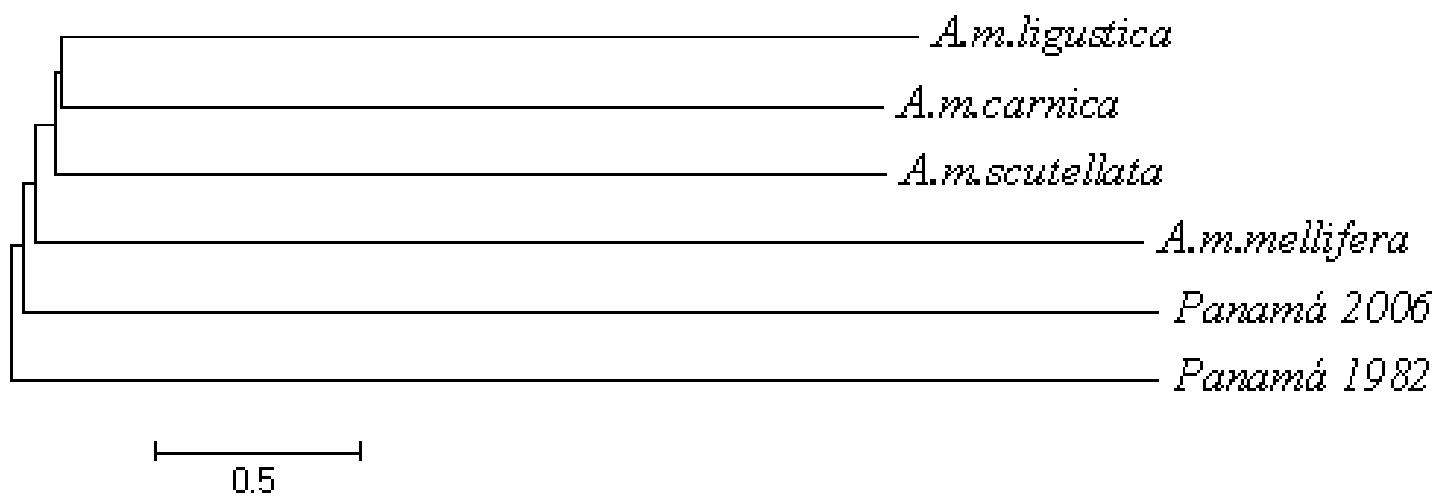

Figura 42: Dendograma de proximidade morfológica construído a partir das distâncias quadradas de Mahalanobis entre os pares de populações.

A representação gráfica das análises discriminantes (Figura 43) mostra os seis grupos claramente distintos e as duas populações africanizadas são as mais diferenciadas, bem como as $A$. m. mellifera, que ficam mais afastadas do centro da distribuição. Assim 
como em todas as outras análises, $A$. m. ligustica e $A$. $m$. carnica ficam mais proximamente agrupadas. 
KEY ( 6 olasses)

africanizada panama1982 africanizada panama2006

1 igustica

carnica

mel 1 i fera

- Center

- Training Sample

+ Test Sample

-Unknown Sample

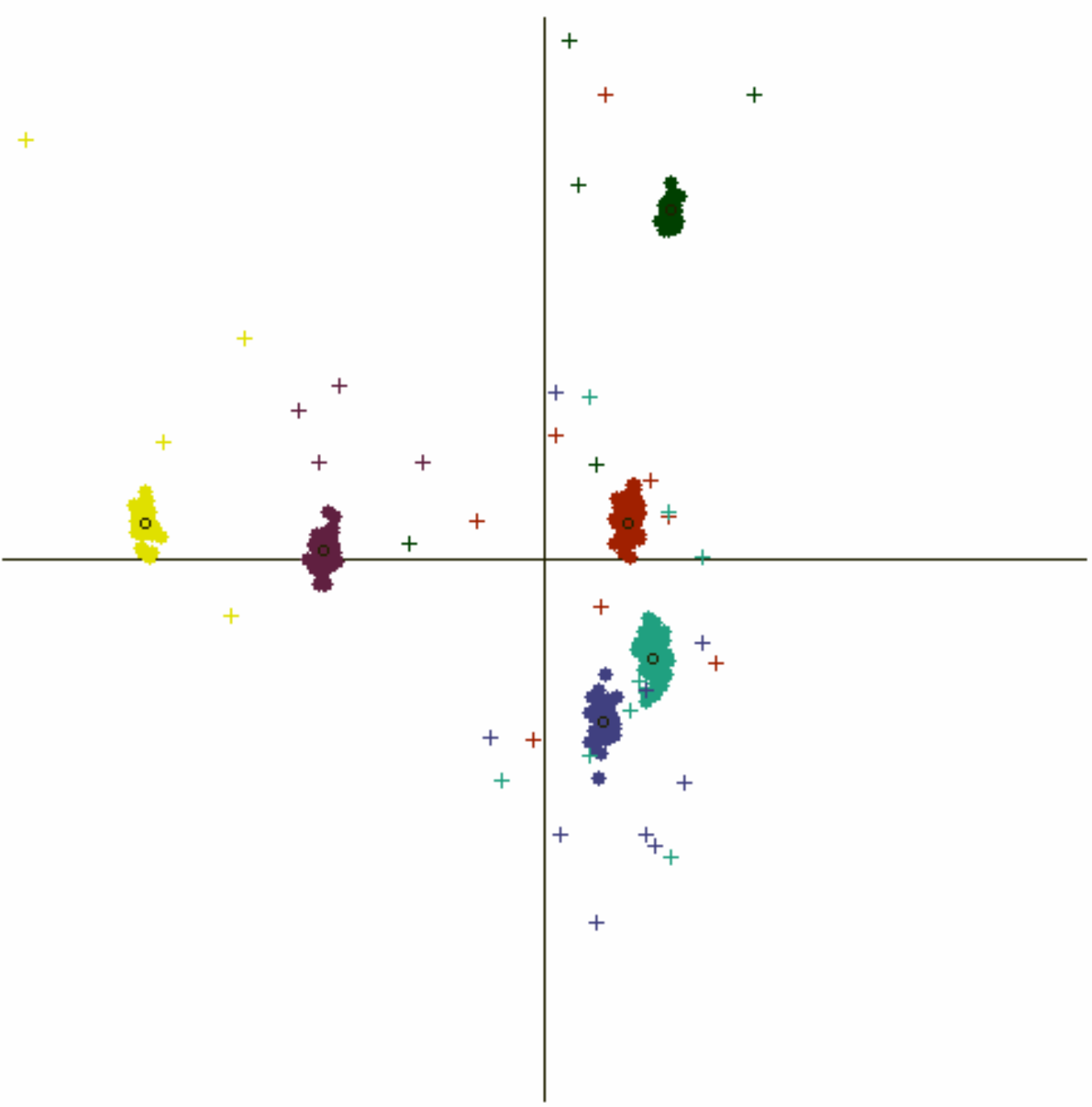

Figura 43: Representação gráfica da distribuição das subespécies de $A$. mellifera e das abelhas do Panamá de acordo com as análises discriminantes lineares (LDA) calculadas pelo software ABIS. 
Já as análises discriminantes não lineares foram capazes de classificar $100 \%$ dos indivíduos dentro de seus respectivos grupos, enquanto nos testes de validação cruzada com $10 \%$ e $20 \%$ de indivíduos utilizados com desconhecidos foram corretamente identificados respectivamente $94,7 \%$ e 94,4\% dos indivíduos. As distâncias quadradas de Mahalanobis entre os centróides dos pares de populações (Tabela 36) se apresentaram muito maiores nas análises discriminantes não lineares do que nas análises lineares.

Tabela 36: Distâncias quadradas de Mahalanobis entre os centróides das distribuições dos grupos estudados calculados pelo software ABIS a partir de equações discriminantes não lineares (KDA).

\begin{tabular}{|c|c|c|c|c|c|}
\hline & Panamá 2006 & A.m.ligustica & A.m.carnica & A.m.mellifera & A.m. scutellata \\
\hline Panamá 1982 & 29.89 & 43.19 & 43.55 & 43.74 & 42.53 \\
\hline Panamá 2006 & & 32.04 & 32.40 & 32.64 & 30.79 \\
\hline A.m.ligustica & & & 8.84 & 16.47 & 12.93 \\
\hline A.m.carnica & & & & 16.65 & 14.17 \\
\hline A.m.mellifera & & & & & 16.44 \\
\hline
\end{tabular}

O dendograma de proximidade morfológica (Figura 44) construído a partir das distâncias quadradas de Mahalanobis mostrou as duas populações panamenhas num ramo distinto das demais. As duas subespécies do ramo C (Ruttner, 1988) A. m. ligustica e A. m. carnica ficam agrupadas em um único ramo, seguidas de $A$. $m$. scutellata e $A$. m. mellifera.

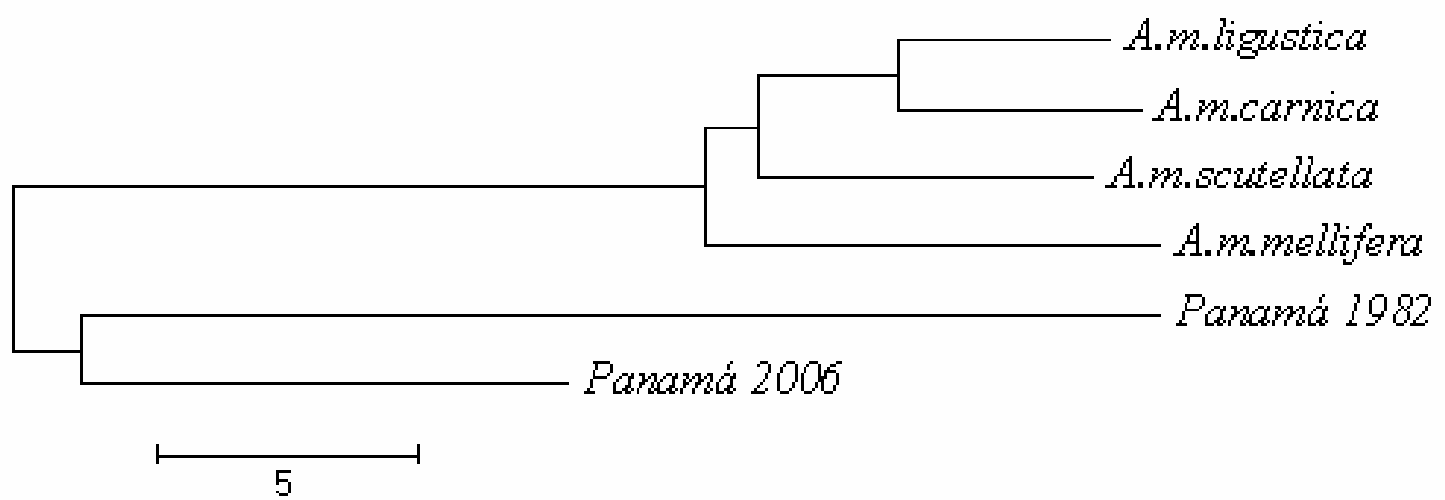

Figura 44: Dendograma de proximidade morfológica entre os grupos de abelhas do Panamá estudados construído a partir das distâncias quadradas de Mahalanobis calculadas pelo software ABIS por análises discriminantes não lineares (KDA).

A representação gráfica dos grupos após as análises discriminantes não lineares (Figura 45) mostrou os dois grupos de abelhas africanizadas bem separados do restante dos 
grupos, sendo que as outras quatro subespécies ficam mais próximas ao centro da distribuição, com $A$. m. ligustica e $A$. m. carnica apresentando certa sobreposição enquanto $A$. m. scutellata e $A$. m. mellifera estão muito proximamente posicionadas. 
KEY ( 6 ol asses)

마 $\operatorname{licanizada~panama1982}$

africanizada panama2006

li gustica

carnica

mellifera

acutel lata

- Center

- Training Samole

+ Test Sample

-Unknown Sample

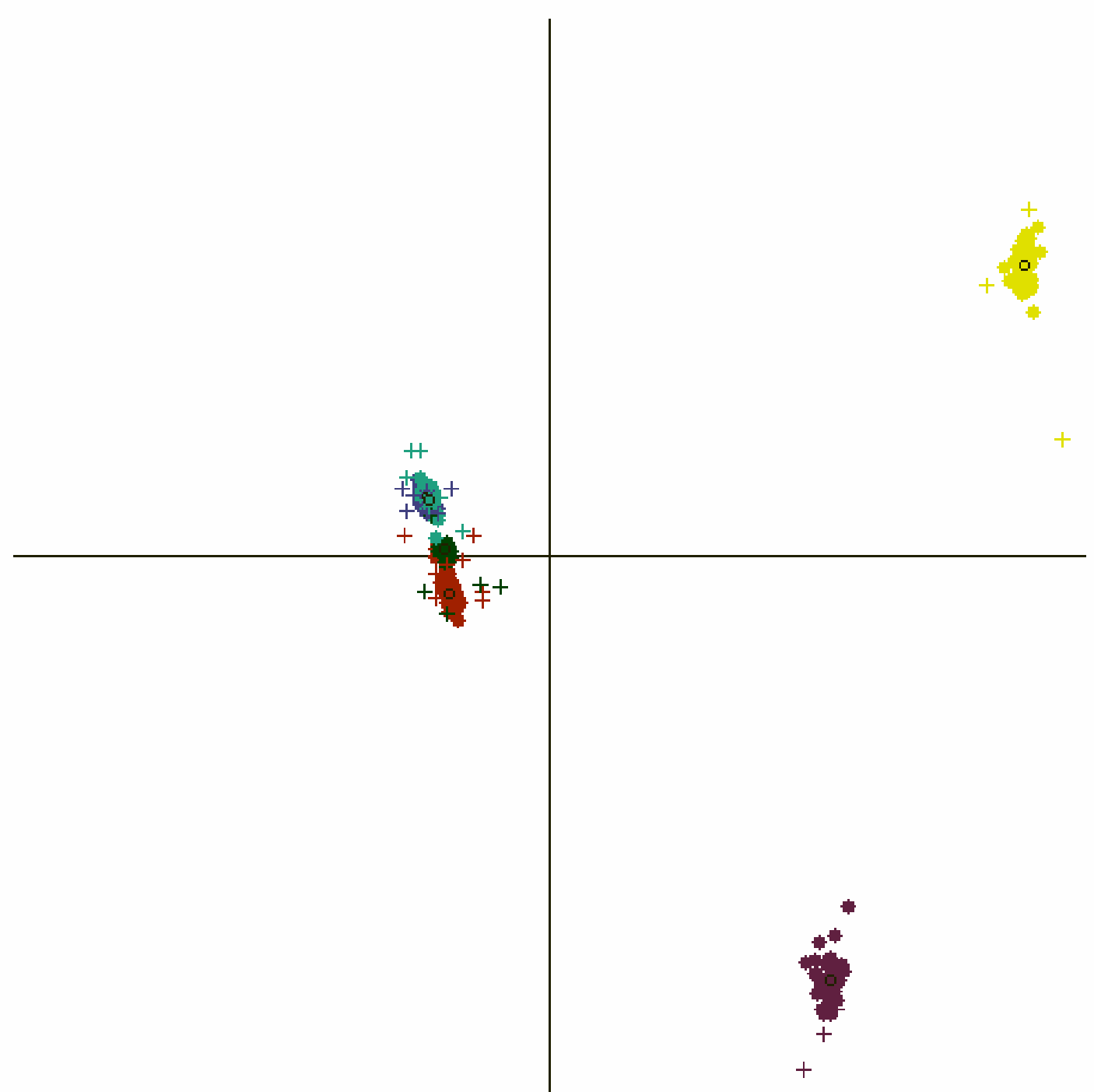

Figura 45: Representação gráfica dos grupos de abelhas do Panamá estudados após análises discriminantes não lineares (KDA) realizadas pelo software ABIS. 


\subsection{4 - DNA mitocondrial.}

Dentre as 10 colônias amostradas no Panamá em 1982, nove delas apresentaram DNA mitocondrial de origem africana e somente uma delas teve sua origem materna identificada como sendo de origem européia (Figura 46).

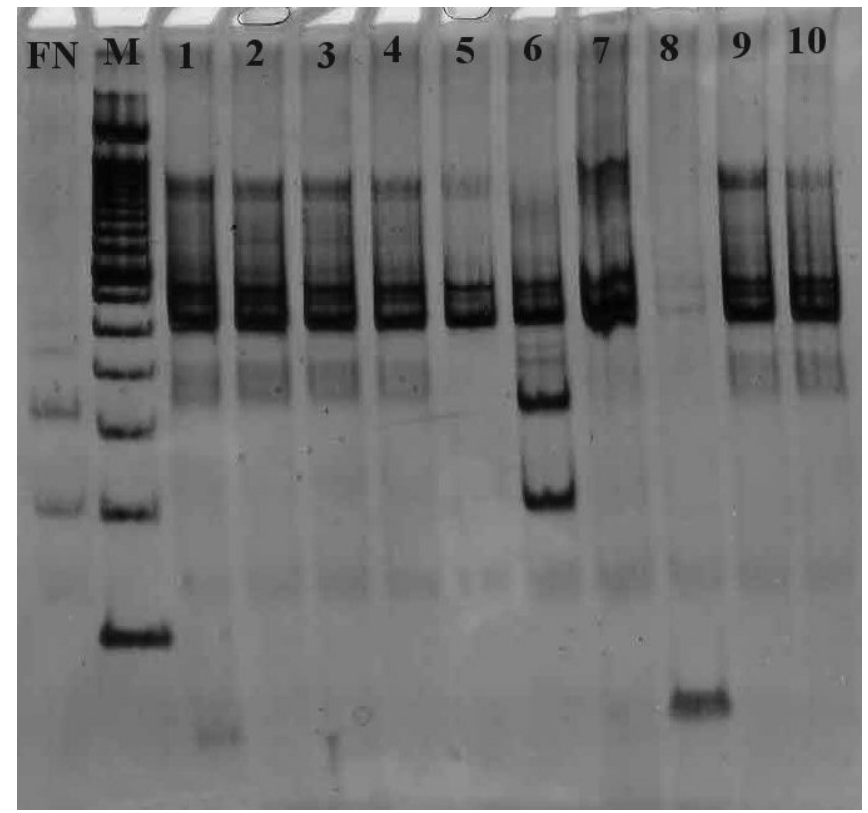

Figura 46: Gel com as amostras de DNA mitocondrial da população do Panamá de 1982. As raias de 1 a 10 representam as amostras panamenhas, a raia $\mathrm{M}$ indica o marcador de peso molecular e a raia FN é a amostra controle de DNA mitocondrial europeu proveniente de Fernando de Noronha. A amostra na raia oito falhou, mas foi repetida em outro gel e foi identificada como sendo de origem africana.

Já as amostras coletadas 24 anos mais tarde apresentaram uma uniformidade nos tipos apresentados, sendo que todas foram identificadas como tendo seu DNA mitocondrial de origem africana, indicando uma completa substituição dos mitótipos europeus na região. 
De

Discussão 
Desde seu surgimento as abelhas africanizadas sempre foram foco de muitos estudos, uma vez que apresentam diversas peculiaridades em sua biologia quando comparadas com as diversas subespécies de origem européia, sobre as quais existem inúmeros trabalhos. Apesar de as abelhas africanas terem escapado da quarentena em 1957, os primeiros estudos sobre essas abelhas somente começaram em meados da década de 60 e, como nada se sabia à época sobre a biologia básica destas abelhas e seu manejo, e como o número de acidentes envolvendo humanos aumentava gradativamente, a identificação deste híbrido foi uma das primeiras grandes preocupações, tendo sido realizados estudos aprofundados já nos primeiros trabalhos desenvolvidos. Gonçalves em 1970 realizou uma série de cruzamentos entre abelhas africanizadas e italianas (A. m. ligustica) com os respectivos retrocruzamentos, de onde foram extraídas diversas medidas da cabeça e tórax de operárias e zangões. Das 63 medidas extraídas, 58 eram maiores nas abelhas européias, fato este que mostrava que as abelhas européias são maiores que as africanizadas de uma maneira geral. De acordo com Ruttner (1988), as abelhas européias são maiores do que as africanas, sendo que os valores de comprimento da asa anterior é um dos caracteres morfológicos mais utilizados nas análises morfométricas clássicas para identificação das subespécies. Dentre as subespécies introduzidas no Brasil, a que apresenta maior valor de comprimento de asa anterior é de $A$. m. carnica, seguida por $A . m$. mellifera, A. m. ligustica e $A$. m. scutellata. Os dados aqui apresentados mostram uma variação das medidas obtidas para cada população quando são analisadas de uma maneira espacial no território brasileiro, demonstrando uma diminuição no tamanho das asas em direção ao norte do país. Essa diminuição sugere um gradiente de africanização, com populações apresentando um menor componente genético em direção ao norte do país. Tal hipótese é corroborada pelos perfis isoenzimáticos das populações brasileiras (Del Lama et al., 1988; 1990; Lobo \& Krieger, 1992; Rotta, 1999; Diniz et al., 2003), que mostram uma variação semelhante à encontrada nas asas das populações estudadas. Em sua maioria, os trabalhos envolvendo isoenzimas utilizam o loco da Malato Desidrogenase 1 (Mdh1) como um dos marcadores, uma vez que esta apresenta três alelos que podem ser considerados como diagnósticos dos 
ramos evolutivos e que, apesar de não estarem fixadas nas respectivas subespécies, apresentam freqüências gênicas bastante diferenciadas, permitindo análises de mistura racial (Contel et al., 1977). As diferenças nas taxas de africanização das populações têm sido constantemente atribuídas aos valores adaptativos de determinados genes que conferem alguma vantagem adaptativa (Lobo \& Krieger, 1992). Entretanto, recentemente também foi levantada a hipótese de o locus da Mdh1 estar sob ação da seleção natural (Del Lama et al., 2006), o que dificultaria as interpretações sobre o uso deste marcador como identificador do grau de africanização das populações.

Estas diferenças na clina das freqüências gênicas de marcadores europeus no eixo norte sul do Brasil também podem refletir a existência de apiários europeus nas regiões sul e sudeste antes da chegada das abelhas africanizadas àquelas regiões (Gonçalves, 1994) bem como as tentativas de diminuir o grau de africanização das populações com a introdução constante de matrizes européias na população, fato muito comum nas primeiras décadas de africanização (Gonçalves, 1974). Tais introduções ocorreram principalmente nas regiões sul e sudeste do país, fato este que pode ter contribuído ainda mais para essa diferença.

Juntamente com explicação de diferentes misturas raciais influenciando a variação do tamanho das asas das abelhas africanizadas, os fatores ambientais não podem ser excluídos, uma vez que são de extrema importância na fisiologia dos organismos (Dillon $e t$ al., 2006). De acordo com Bergmann (1847), o tamanho corporal dos organismos tende a aumentar à medida que as populações se localizem mais distantes da linha do Equador e, consequentemente, mais frios. Esta teoria foi baseada em grupos de organismos endotérmicos e é conhecida como regra de Bergmann. Ray (1960) examinou o tamanho corporal em 17 espécies de ectotérmicos criados em baixas e altas temperaturas e observou que o fenômeno se repete para tais organismos. Em abelhas do gênero Apis, também foi demonstrado que populações de regiões mais frias tendem a ter um maior tamanho corporal (Ruttner, 1988). Desta maneira, provavelmente esse fator também está 
influenciando o tamanho de nossas abelhas juntamente com o componente genético presente nas populações.

Um terceiro, mas não menos importante fator a ser levado em conta é a historia apícola brasileira e a formação de nossos apicultores. Durante muitos anos, a apicultura profissional brasileira ficou restrita ao sul e sudeste do país, sendo que somente nos últimos anos é que a região nordeste começou a apresentar um destacado crescimento na produção apícola nacional (Gonçalves, 2004) e uma prática muito comum entre os apicultores profissionais é o uso de cera alveolada na fundação de novos favos. É sabido que as abelhas constroem as células de cria de acordo com as medidas encontradas na fundação da cera e este tamanho varia de acordo com as subespécies (aproximadamente 5,2 $\mathrm{mm}$ de largura interna para abelhas européias e 4,8 $\mathrm{mm}$ para abelhas africanizadas) (Piccirilo \& DeJong, 2003). Por muito tempo foi e ainda é muito usada em várias localidades no sul e sudeste do país a cera estampada com padrões europeus, devido principalmente ao fato de diversos estampadores de cera terem sido importados da Europa (Gonçalves, informação pessoal). Foi demonstrado recentemente por McMullan \& Brown (2006) que abelhas criadas em células de cria maiores e menores que o padrão natural da subespécie tendem a seguir os padrões das células, ou seja, abelhas criadas em células maiores tendem a ser maiores e abelhas criadas em células menores tendem a ser menores. É importante comentar que a prática do uso de cera estampada é muito mais freqüente no sul e sudeste do Brasil do que nas regiões do norte e nordeste.

Desta maneira, tendo em vista os fatos expostos acima, é possível que as abelhas do sul e sudeste do país sejam criadas em células de maior tamanho e consequentemente também apresentem um tamanho relativamente maior do que as abelhas do norte e nordeste, como evidenciado por nossos dados.

Existe ainda um outro fator a ser levado em consideração, que é a questão do tamanho corporal e a disponibilidade de alimento. É sabido que em Hymenoptera, o tamanho corporal dos adultos está profundamente relacionado com a quantidade e com a qualidade de alimento consumido durante a fase larval (Plowright \& Jay, 1977; Ribeiro, 
1994; Roulston \& Cane 2002; Peruquetti, 2003). É comum na região nordeste do país, durante os meses de seca, onde há pouca ou nenhuma disponibilidade de pólen, que alguns apicultores, na falta de dietas adequadas alimentem suas abelhas com fubá (Gonçalves, informação pessoal), substância essa que é rapidamente coletada pelas abelhas, mas de baixíssimo valor nutricional e que afeta toda a fisiologia das abelhas (Cremonez et al., 1998), inclusive o seu tamanho. Em contraste, essa escassez de pólen acontece muito mais raramente nas regiões sul e sudeste, este pode ser um outro influenciador do tamanho corporal das abelhas e da diferença encontrada nessa variação clinal de norte a sul do país.

Uma vez que os dados de latitude e temperatura apresentam uma correlação, todas as inferências feitas para os dados de temperatura podem também ser utilizadas para os dados de latitude.

Em 2003, Quezada-Euán e colaboradores demonstraram a existência de gradientes de mistura racial em populações peruanas de abelhas africanizadas de acordo com uma variação de altitude. Neste trabalho, realizado em diversas faixas de altitude na cordilheira dos Andes, foi demonstrado que a contribuição das abelhas européias nas populações aumenta à medida que a altitude aumenta e a temperatura consequentemente diminui. Nossos dados não mostraram correlação significante entre as medidas de tamanho de asa e altitude, indicando que este fator não influencia esta característica nas abelhas das populações aqui amostradas. Entretanto, a maior altitude encontrada em nossos dados é de 915 metros na cidade de Curitiba - PR. Quando comparada com as altitudes estudadas no trabalho realizado no Peru, que variavam de 0 a 3500 metros de altitude (Quezada-Euán et al., 2003), a população de Curitiba ficaria na faixa mais baixa entre as altitudes estudadas, onde praticamente todas as colônias analisadas apresentam morfologia africanizada e padrões de DNA mitocondrial correspondentes ao de $A$. $m$. scutellata. É possível que em tais altitudes tão baixas quanto as amostradas neste trabalho não apresentem influência. Um outro fator que dificultaria a comparação dos dados de tamanho de asa com a altitude da localidade amostrada é o fato das populações estarem muito espalhadas pelo Brasil. Uma comparação mais confiável poderia ser feita estudando-se diversas populações dentro de 
uma pequena variação latitudinal, mas com grande variação de altitude, assim como o trabalho realizado no Peru.

Ainda dentro das comparações entre as populações de abelhas africanizadas, os dados de análise de DNA mitocondrial nos fornecem importantes informações quanto à estrutura genética populacional.

Em nossas análises, encontramos uma quase que exclusividade de mitótipos de origem africana, sendo que somente três das 394 colônias analisadas neste trabalho apresentaram DNA mitocondrial de origem européia, sendo que todos os três são padrões tipicamente encontrados em abelhas do ramo $\mathrm{C}$, como em $A$. m. ligustica, por exemplo. Nossos dados são muito parecidos com os encontrados por outros trabalhos, os quais mostram grande contribuição de $A$. $m$. scutellata no tocante à origem do DNA mitocondrial das atuais populações (Hall \& Muralidharan, 1989; Rotta, 1999; Collet et al., 2006).

Alguns trabalhos sugerem que durante o processo de expansão dos enxames africanizados, o acasalamento mais comum a ocorrer é o de zangões africanizados com rainhas européias (Gonçalves, 1970; Michener, 1975; Rinderer, 1986). Entretanto, a quase que completa substituição dos enxames com origem materna européia por populações com predominância africana contradiz essa idéia. Como diversos trabalhos mostram a presença de material genético nuclear de origem européia nas atuais populações (Del Lama et al., 1990; Rotta, 1999; Whitfield et al., 2006), fica ainda uma incongruência entre tais dados de DNA mitocondrial e nuclear. Para tanto, algumas explicações são sugeridas de modo a esclarecer tamanha discrepância, uma vez que a contribuição européia em relação ao material genético nuclear das populações brasileiras varia entre $5 \%$ e $33 \%$, sendo em sua maioria de origem do oeste europeu (Lobo et al., 1989; Del Lama et al., 1990; Rotta, 1999; Cristino 2003) e o DNA mitocondrial gira sempre entre 5\% e 1\% (Rotta 1999; Collet et al., 2006).

Uma destas explicações, que frequentemente vem sendo usada é a heterose negativa ou adaptabilidade reduzida dos híbridos (Clarke et al., 2001). Harrison \& Hall 
(1993) demonstraram que abelhas híbridas apresentam taxas metabólicas menores que de abelhas africanizadas e tão baixas quanto abelhas européias. Mostram ainda que abelhas com maternidade européia e paternidade africanizada apresentam estas taxas metabólicas mais baixas do que híbridos com maternidade africanizada e paternidade européia, sugerindo uma incompatibilidade nuclear-citoplasmática que colocaria os híbrido de maternidade européia em desvantagem na competição com as outras abelhas, fato este que auxilia a explicação da quase extinção dos mitótipos de origem européia nas atuais populações africanizadas.

Um outro método utilizado para medir distúrbios durante o desenvolvimento ontogenético é a assimetria flutuante. Esta pode ser definida como variações aleatórias em pequena escala que afetem a simetria bilateral dos organismos (Schneider et al., 2004a). Como a assimetria flutuante resulta da inabilidade de programas genéticos de desenvolvimento em resistir a perturbações, assume-se que ela está negativamente correlacionada com estabilidade ontogenética e adaptabilidade (Palmer, 1994) e que eventos de hibridização podem aumentar esta assimetria flutuante, devido talvez a coadaptação de complexos gênicos (Smith et al., 1997). Desta maneira, Schneider e colaboradores (2003) demonstram uma maior taxa de assimetria flutuante em híbrido com maternidade européia e paternidade africanizada quando comparada com os grupos parentais e com o híbrido de maternidade africanizada e paternidade européia.

Um outro fenômeno que vem sendo relatado é a usurpação de ninhos de origem européia por parte das abelhas africanizadas. Esta usurpação é uma foram de parasitismo reprodutivo social que consiste da invasão das colônias européias por parte de enxames africanizados, onde as abelhas invasoras matam a rainha européia da colônia e a substituem pela rainha do enxame, causando a imediata perda do DNA mitocondrial de origem européia. As taxas anuais de usurpação giram em torno de 5\% na Venezuela (Danka et al., 1992) e entre 0\% e 40\% no México (Vergara et al., 1993). Ainda é desconhecido o fator que leva as abelhas africanizadas a encontrar e invadir colônias européias, mas é possível que esteja relacionado com feromônios que indiquem a condição 
da colônia e também com a presença de rainhas, uma vez que a grande maioria das invasões ocorre em colônias órfãs ou fracas, com rainhas confinadas para introdução. Rainhas recém introduzidas são usurpadas entre duas a oito vezes mais do que colônias com rainhas já estabelecidas (Schneider et al., 2004b). Entretanto, outros fatores também podem estar envolvidos, uma vez que colônias com rainhas também são invadidas (Danka et al., 1992; Vergara et al., 1993).

Estes fatores em conjunto ajudam a explicar a quase que completa substituição dos mitótipos de origem européia em todas as populações de abelhas africanizadas estudadas neste trabalho. A substituição mais impressionante talvez seja a substituição dos mitótipos europeus por africanos na população de Ribeirão Preto - SP entre os anos de 1968 e 2002, uma vez que é a única documentada ate o momento para populações brasileiras. Em 1968, em torno de $40 \%$ das colônias amostradas em Ribeirão Preto - SP apresentavam seu mitótipo como sendo de origem européia, enquanto que a mesma população, amostrada 34 anos depois não apresentou traços de DNA mitocondrial europeu. Juntamente com os dados de morfometria tradicional das asas anteriores, que claramente indicam que as abelhas de 1968 são híbridas, o fato de uma porcentagem tão alta de mitótipos europeus terem sido encontrados neste pode ser explicado pela distribuição, entre os anos de 1965 e 1972, de mais de 23 mil rainhas italianas virgens que foram entregues aos apicultores pelo Departamento de Genética da Faculdade de Medicina de Ribeirão Preto, em uma tentativa de diminuir a agressividade das abelhas africanizadas. Foi recomendado aos apicultores que substituíssem as rainhas de suas colônias mais agressivas pelas rainhas italianas, de modo a eliminar esses genes para abelhas mais agressivas da população e introduzir novos genes europeus (Gonçalves, 1974). Essa mudança, a priori foi bem recebida pelos apicultores e resultou em uma redução da agressividade das abelhas. Entretanto, ao perceber que os híbridos $\mathrm{F} 1$ eram menos produtivos que as abelhas africanizadas, os apicultores passaram a eliminar as rainhas européias, adaptando-se a trabalhar com rainhas híbridas que davam origem a abelhas mais agressivas, porém mais produtivas (De Jong, informação pessoal). O fato de os apicultores eliminarem as rainhas de origem européia 
após um tempo, ajudou ainda mais a eliminar os mitótipos europeus das populações, que, em conjunto com os outros fatores, contribuiu grandemente para este fato.

Já a situação dos enxames amostrados no Panamá é diferente. Enquanto a população de Ribeirão Preto - SP já estava estabelecida em um apiário experimental por vários anos, sendo constantemente manipulada e obtendo assistência técnica quase que diariamente, as amostras panamenhas de 1982 foram coletadas em colônias selvagens ou em enxames naturais provenientes da natureza. Estas, além de representarem as primeiras ondas migratórias de abelhas africanizadas dentro do país, demonstram uma situação mais natural, pois se tratavam de material coletado na natureza. Os dados de comprimento das asas anteriores da população de 1982 estão de acordo com aqueles publicados por Boreham \& Roubik (1987). Neste trabalho, os autores mostram uma discreta diminuição do tamanho das asas entre os anos de 1982 e 1987, fato este que fica mais claro quando comparamos as populações de 1982 e 2006 . Os dados de DNA mitocondrial se mostram diferentes dos encontrados para a população de Ribeirão Preto, pois somente um dos 10 enxames coletados apresenta DNA mitocondrial de origem européia. É possível que este seja um achado mais próximo da realidade da frente de expansão das abelhas africanizadas, onde elas provavelmente se hibridizam com as abelhas européias existentes em apiários das regiões recém colonizadas e continuam sua expansão, fato este indicado pelos dados de morfometria tradicional e também pela presença de DNA mitocondrial de origem européia nos enxames selvagens coletados. Quando comparamos os dados de 1982 com os de 2006, podemos observar diminuição do tamanho médio das asas das populações até um tamanho menor que o encontrado para as abelhas $A . m$. scutellata, fato este constantemente encontrado nas abelhas africanizadas presentes em outras populações descritas neste trabalho, principalmente as de regiões mais quentes. É interessante notar que mesmo com a presença de apiários comerciais com a presença de abelhas européias antes da chegada das abelhas africanizadas no Panamá, Boreham \& Roubik (1987) comentam que nunca haviam encontrado enxames naturais estabelecidos naquele país antes da chegada das abelhas africanizadas. 
Nos estudos de morfometria, quando diversos caracteres de amostras são medidos simultaneamente, as distâncias de Mahalanobis podem ser tomadas como estimativas de diversidade genética entre os grupos. Essa diversidade é obtida segundo diferenças fisiológicas, morfológicas e ecológicas, avaliadas a partir de um grupo de genótipos (Ghadery et al., 1984). No presente trabalho sobre variabilidade genético-morfológica de populações Neotropicais de Apis mellifera, as medidas de deformações relativas das asas são os caracteres que nos permitem avaliar a variabilidade genética das populações de abelhas africanizadas.

Desta maneira, quando foram comparadas as populações de abelhas africanizadas juntamente com as subespécies ancestrais e também com as abelhas italianas de Fernando de Noronha - PE, foram observadas distâncias de Mahalanobis muito grandes quando levadas em consideração as distâncias entre populações africanizadas e as subespécies ancestrais européias, sendo que as $A$. m. ligustica e $A$. m. carnica foram as mais distantes, alternando-se nessa posição de acordo com a população, seguidas de A. m. mellifera (Tabela 3). Estes dados podem refletir os dados moleculares e isoenzimáticos, que mostram que a subespécie européia que mais contribui para as populações africanizadas é justamente $A$. m. mellifera (Del Lama et al., 1990; Rotta, 1999; Whitfield et al., 2006). Esta influência é confirmada quando analisado o dendograma de proximidade morfológica (Figura 10), onde $A . m$. ligustica e $A . m$. carnica ficam agrupadas em um ramo isolado na base do dendograma, seguidos pela população de Fernando de Noronha - PE e depois $A . m$. mellifera. Logo em seguida ficam a população de Ribeirão Preto 1968 e A. m. scutellata, com todas as populações africanizadas agrupadas na seqüência. Isso confirma também por essa nova metodologia aplicada pela primeira vez em abelhas africanizadas com o intuito de avaliação da variabilidade populacional, que tais abelhas são muito parecidas ou próximas a A. m. scutellata, confirmando também os dados de outros marcadores moleculares, como isoenzimas (Lobo et al., 1989; Del Lama et al., 1990; Sheppard et al., 1991b; Rotta, 1999), DNA mitocondrial (Sheppard et al., 1991a; Rotta, 1999; Diniz et al., 2003; Collet et al., 
2006) microssatélites (Clarke et al., 2001) e mutações pontuais de DNA nuclear (Whitfield et al., 2006).

Este dendograma, além de nos indicar a maior influência de $A . m$. scutellata nas populações africanizadas, fato que também é evidenciado pelas distâncias de Mahalanobis, mostra ainda que as abelhas de Fernando de Noronha - PE, que foram introduzidas na ilha em 1984 (Malagodi et al., 1986) são descendentes de abelhas européias, mas que não se encaixam no perfil morfométrico de nenhuma das subespécies estudadas. Quando tais abelhas foram introduzidas na ilha, as rainhas do tipo comercial italiana (predominantemente $A . m$. ligustica) foram importadas da Califórnia e os zangões foram produzidos por uma rainha importada da Geórgia, ambas localidades do EUA, que na ocasião se encontrava livre da presença de abelhas africanizadas. Embora os dados de freqüências isoenzimáticas e de DNA mitocondrial indiquem que estas abelhas apresentem um perfil genético típico de abelhas A. m. ligustica (Rotta, 1999), tais resultados não parecem ser os mesmos quando o padrão de venação de asas é estudado. Devido ao fato de todas as colônias da ilha serem filhas de rainhas de cinco colônias inseminadas com zangões de uma única colônia não seja representativa da variabilidade morfológica das asas da subespécie. Como tais abelhas estão na ilha, isoladas de qualquer contato com outras colônias há mais de 20 anos, um possível efeito de inbreeding pode estar influenciando os padrões de venação de asas. Em 1976, Brückner mostrou a importância da variabilidade genética na simetria das asas anteriores de $A$. mellifera, endocruzando abelhas por quatro gerações e medindo as disfunções ontogenéticas a partir da simetria das asas. Neste experimento, operárias e zangões provenientes de colônias endocruzadas apresentavam um maior desvio nas medidas tomadas, distanciando-se das demais. Assim, é possível que as abelhas introduzidas na ilha tenham passado por um efeito gargalo no que diz respeito aos genes de posicionamento das nervuras de asa e que, na re-expansão da população, um novo perfil tenha se formado. 
Não se pode descartar também a possibilidade de que alguma adaptação ambiental tenha ocorrido nestas abelhas, uma vez que estão em um clima completamente diferente do qual a subespécie se desenvolveu bem como um efeito carona de determinados genes de posicionamento ligados a algum gene sob efeito da seleção natural.

Nossos dados indicam que, embora as abelhas de Fernando de Noronha apresentem seus perfis isoenzimático e de DNA mitocondrial típicos de $A$. m. ligustica, as mesmas não podem ser utilizadas com tal finalidade no que diz respeito a morfometria das asas, devendo ser tratada diferencialmente quando utilizada em estudos morfométricos.

Quando tratamos das populações africanizadas, estas se encontram todas agrupadas em um único ramo. Uma certa concordância entre os agrupamentos é encontrada quando comparamos as distâncias morfológicas e geográficas das populações, e, apesar de discrepâncias serem encontradas, podemos reconhecer, por exemplo, um ramo com as populações do sul do Brasil e outro com todas as populações do Rio Grande do Norte.

Um padrão similar e mais exato em relação à correlação distância morfológica $\mathrm{X}$ distância geográfica das populações foi encontrado por Mendes (2006) ao estudar populações de Nannotrigona testaceicornis provenientes de três estados brasileiros diferentes.

No presente estudo, as taxas de acerto nas classificações e identificações dos indivíduos dentro dos respectivos grupos são relativamente baixas, ficando na casa dos $43,5 \%$ e $36,5 \%$ respectivamente. Estas baixas taxas podem ser explicadas pela grande similaridade entre as populações de abelhas africanizadas pode ser atribuída a algumas causas, como a grande capacidade enxameatória apresentada por estas abelhas (Kerr et al., 1970), o que aumenta muito o fluxo gênico entre as populações e acaba por dificultar a diferenciação morfológica dos grupos.

Outro fator que ajuda na rápida mistura das populações é a existência de apicultura migratória, principalmente nos estados do nordeste do Brasil (Gonçalves, informação pessoal). Tal prática leva os apicultores a transportarem milhares de colméias para os diversos lugares onde existirem floradas para que a produção de mel seja aumentada. 
Entretanto, no nordeste brasileiro as taxas de enxameação chegam a atingir 50\%, fato este que significa uma grande introdução de genótipos de uma região em outra.

Esse transporte de material genético de uma região para outra tem sido mais frequentemente observado no nordeste brasileiro nos últimos 10 anos. Porém, também pode ocorrer em menor escala introdução de rainhas adquiridas de produtores de rainhas e que são transportadas via correio. Sempre que grandes quantidades de rainhas compradas de outras regiões são introduzidas em um apiário há a alteração de freqüências gênicas e consequentemente, uma maior mistura das populações.

De acordo com Ruttner (1988), as amostragens para classificação dos grupos devem ser feitas tomando-se entre 10 e 20 operárias por colônia e os valores utilizados nas análises discriminantes e de componente principal devem sempre ser representados pelas médias da colônia de cada uma das medidas, utilizando assim a colônia como unidade evolutiva. Ao utilizarmos as médias das colônias como medidas, eliminamos uma parte da variabilidade intracolonial que passa a ser considerada aleatória, o que é razoável quando estamos comparamos grupos distintos, como populações e subespécies, por exemplo. Em nosso trabalho, as médias das colônias foram realizadas a partir de cinco indivíduos por colônias e também com 10 indivíduos por colônia no caso das amostras da análise das populações panamenhas.

Neste trabalho, apesar de uma taxa de acerto muito baixa ter sido obtida na média de todas as populações, chama a atenção do poder discriminatório da técnica quando comparadas somente as subespécies, com taxas de acerto girando acima de $90 \%$ de acerto para as subespécies européias. A. m. scutellata, apesar de apresentar somente uma taxa de $55,7 \%$ de acerto, não apresenta nenhuma de nossas amostras classificada como as outras subespécies, sendo que os indivíduos erradamente classificados sempre são classificados como pertencentes a alguma população africanizada (Tabela 5). Quando estas taxas de acerto nas classificações e identificações corretas são comparadas com as taxas de classificação e identificação das colônias, ela sobe para $70 \%$ e $41 \%$ respectivamente. Novamente, as subespécies puras apresentam altas taxas de acerto nas identificações dos 
grupos, com todas as subespécies européias apresentando $100 \%$ de acerto nos testes de validação cruzada e novamente $A$. $m$. scutellata somente apresenta colônias classificadas erradamente como populações de abelhas africanizadas e não com as outras subespécies (Tabela 11). Estes dados são muito animadores, uma vez que abrem a possibilidade de uma nova metodologia para identificação das subespécies de $A$. mellifera, mais rápida e tão eficiente quanto as atuais. A atual técnica de morfometria tradicional usada na discriminação das subespécies envolve medições de várias partes do corpo das abelhas e relativamente demorada (Prof. Dr. Stephan Fuchs, informação pessoal). Assim sendo, muito tempo é ganho em relação ás medidas de morfometria tradicional, que também possui uma taxa de $100 \%$ de acerto nas classificações subespecíficas dos grupos estudados neste trabalho.

Quando comparados com as taxas de acerto nas classificações de Melipona bicolor bicolor e $M$. b. schencki (Francoy et al., dados não publicados), os dados subespecíficos de $A$. mellifera se mostram melhores, uma vez que $86 \%$ dos indivíduos pertencentes às duas subespécies são corretamente classificados dentro dos respectivos grupos de Melipona bicolor. Entretanto, estas subespécies ainda não foram analisadas quanto à discriminação de suas colônias.

Quando analisamos a distribuição gráfica da análise discriminante (Figura 11) é possível distinguir quatro grupos que correspondem aos ramos evolutivos propostos por Ruttner (1988). As abelhas africanas e africanizadas formam um cluster, correspondendo ao ramo A e confirmando a maior influência das abelhas africanas nas populações africanizadas, A. m. ligustica e A. m. carnica formam um segundo grupo, representando o ramo $\mathrm{C}, A . m$. mellifera, representante do ramo $\mathrm{M}$ também fica isolada das demais e um quarto grupo, somente com a população de Fernando de Noronha pode ser observado. Estudos adicionais utilizando-se as asas de todas as 26 subespécies de $A$. mellifera estão sendo realizados para a verificação da acurácia da técnica de morfometria geométrica na discriminação de todas as subespécies. 
Já o software ABIS apresentou resultados ligeiramente melhores do que os da morfometria geométrica em relação à classificação e identificação dos indivíduos das populações de abelhas africanizadas quando analisados em conjunto com os grupos ancestrais, principalmente quando as funções discriminantes não lineares foram utilizadas, sendo que estas atingiram taxas de $52 \%$ de identificações corretas nos testes de validação cruzada. Tanto os dendogramas de proximidade morfológica (Figuras 25 e 26) construídos a partir das distâncias (Tabelas 15 e 17) calculadas pelo software quanto às próprias distâncias mostram uma maior similaridade entre as medidas obtidas para as abelhas africanizadas e para as $A$. m. scutellata.

O ABIS trabalha com medidas de morfometria tradicional como distâncias, ângulos e curvaturas e estas, quando estudadas com as análises discriminantes não lineares, mostram um melhor poder de discriminação do que as deformações relativas analisadas com equações discriminantes lineares. Talvez, uma associação das medidas de deformações relativas com análises discriminantes não lineares aumente mais as taxas de acerto dos grupos estudados.

Uma vez que as subespécies puras apresentaram os padrões de venação de asa muito distintos, as populações de abelhas africanizadas, por apresentarem uma menor variabilidade, ficaram agrupadas em um cluster muito próximo de $A$. m. scutellata. Desta maneira, foi realizado também um estudo utilizando somente as populações de abelhas africanizadas atuais, de modo a avaliar somente a variabilidade das atuais populações viventes.

As taxas de acerto nas classificações e identificações, tanto para indivíduos quanto para colônias das populações de abelhas africanizadas se apresentam mais baixas do que quando comparadas com as análises anteriores com as subespécies envolvidas, novamente refletindo que estas abelhas apresentam padrões de venação de asa muito parecidos entre suas populações, somente apresentando pequenas diferenças. Os valores das análises anteriores estavam aumentados pelas altas taxas de acerto nas classificações das subespécies puras e também da população de Fernando de Noronha. Quando analisadas 
somente as populações atuais de abelhas africanizadas, seja por morfometria geométrica ou pelo ABIS, as taxas de acerto nas classificações são extremamente baixas, ficando na casa dos $20 \%$ para os testes de validação cruzada com morfometria geométrica e perto dos $40 \%$ para os testes com o ABIS. Quando as populações são analisadas quanto às colônias, a taxa de acerto gira em torno de $33 \%$ e, nenhuma dessa taxas nos parece satisfatória para que as técnicas tenham sua utilização recomendadas para a discriminação de populações de abelhas africanizadas. Como discutido anteriormente, todas as populações apresentam seus padrões de venação de asa muito parecidos, dificultando assim uma diferenciação maior. Os fatores dessa grande similaridade também já foram discutidos anteriormente.

Em 2006, Mendes encontrou taxas de acerto bem mais altas nos testes de validação cruzada utilizando indivíduos de diferentes populações de Nannotrigona testaceicornis. Tais taxas, que ficaram em torno de $66 \%$ de acerto nas classificações populacionais foram atribuídas a diversos fatores, como a baixa dispersão por enxameação das colônias desta espécie, ao fato de não haver transporte comercial de colônias, fatos estes que mantém baixo o fluxo gênico entre populações muito distantes e também à baixa variabilidade genética encontrada dentro de uma colméia, uma vez que as rainhas de $N$. testaceicornis acasalam com um único macho. Como esta análise foi realizada somente com indivíduos e não com colônias, não podemos comparar tal parâmetro.

Em 1995, Estoup e colaboradores realizaram um grande estudo envolvendo diversas subespécies dos ramos $\mathrm{M}, \mathrm{A}$ e $\mathrm{C}$ analisadas com microssatélites obtiveram taxas de classificação dos indivíduos tão boas quanto ou piores que nossos dados utilizando as médias das colméias das deformações relativas para as subespécies puras. Enquanto os dados de microssatélite identificam as abelhas com taxas que giram entre $63 \%$ e $100 \%$ dentro dos ramos evolutivos, nossos dados de morfometria geométrica giram entre $86 \%$ e 96\% quando utilizados os valores dos indivíduos (Tabela 5) e ficam na casa dos $100 \%$ quando utilizadas as médias dos indivíduos de mesma colônia (Tabela 10). Vale lembrar que as taxas de erro quando utilizados os indivíduos aparecem somente quanto comparadas abelhas pertencentes ao mesmo ramo evolutivo, com é o caso de $A$. m. ligustica 
e A. m. carnica e também o caso de $A$. m. scutellata e das populações africanizadas. Entretanto, os microssatélites se mostraram mais adequados para a discriminação de populações, com taxas muito altas de classificação, girando entre $22 \%$ e $95 \%$ mas com a grande maioria das taxas de acerto nas classificações populacionais girando entre $75 \% \mathrm{e}$ 95\%. Nossos dados ficam muito aquém disso quando tratados em termos de classificação populacional, girando entre $0 \%$ e $47 \%$ quando tratados os indivíduos (Tabela 8) e entre $0 \%$ e 78,9\% quando tratadas as médias de indivíduos de mesma colônia (Tabela 14).

As distribuições gráficas e os dendogramas de proximidade morfológica calculados nas análises sem as subespécies não parecem mostrar um padrão definido, sendo que somente alguns grupos se aglomeram de maneira coerente, como é o caso de algumas populações do Rio Grande do Norte e do Sul do país. Isso mostra que, apesar de algumas vezes agrupar as populações coerentemente, tais dados não devem ser interpretados com um cunho cladístico e sim como dados fenéticos que mostram a proximidade morfológica das estruturas estudadas entre as diferentes populações ou grupos.

De fato, alguns trabalhos propuseram a utilização das deformações parciais como caracteres em análises cladísticas pelo fato de que, por se basearem em uma configuração de referência, estas poderiam ser utilizadas como caracteres homólogos (Zelditch et al., 1995; Fink \& Zelditch, 1995). Entretanto, após alguma discussão, os trabalhos de Naylor (1996) e de Rohlf (1998) demonstraram diversos problemas na utilização das deformações parciais como caracteres homólogos, como a não independência dos caracteres, entre outros.

Quando comparamos a morfologia de asa da população de Ribeirão Preto - SP em uma escala temporal, podemos verificar que de uma maneira geral, as duas populações apresentam uma grande similaridade com $A$. $m$. scutellata, sendo que a subespécie européia que mais se parece com esse grupo é $A$. m. mellifera e que $A$. m. ligustica e $A$. m. carnica se mostram mais diferenciadas do restante das amostras. Quando comparados com dados de isoenzimas para populações africanizadas do Estado de São Paulo, nossos dados se mostram concordantes com as quantificações do sistema isoenzimático $M d h$, que mostra 
entre $80 \%$ e $85 \%$ de genes africanos pra este locus, entre $12 \%$ a $15 \%$ de genes de $A . m$. mellifera e muito pouca contribuição de A. m. ligustica (Lobo et al., 1989; Sheppard et al., 1991b). Nossos dados parecem indicar que $A$. m. mellifera é a subespécie européia que mais influencia as populações africanizadas. Entretanto, muito provavelmente isso é somente uma coincidência tendo em vista que os dados de morfometria geométrica somente mostram quão parecidos são os grupos estudados. Como Ruttner (1988) demonstra por dados de morfometria tradicional que as subespécies do oeste europeu são muito mais parecidas com as subespécies da África do que com as subespécies do leste europeu, a maior proximidade de $A$. m. mellifera com o ramo das abelhas africanizadas e africanas parece refletir tal constatação. Esta proximidade entre as subespécies africanas e do oeste europeu já foi confirmada também por outros marcadores, como microssatélites (Estou et al., 1995), DNA mitocondrial (Franck et al., 2000) e também por mutações pontuais de DNA nuclear (Whitfield et al., 2006).

As taxas de acerto de identificações ficaram na casa dos $85 \%$ quando analisadas os indivíduos (Tabela 22) e 82\% quando foram avaliadas as médias de indivíduos de mesma colônia (Tabela 25) sendo que em ambos os casos, as maiores taxas de erro ficaram por conta da população de 1968. Talvez por apresentar sinais ainda muito claros de hibridização, como evidenciado pelos padrões de DNA mitocondrial e pelos dados de morfometria tradicional, estas abelhas apresentem uma variabilidade muito grande no posicionamento de suas veias ficando, portanto prejudicada a identificação das abelhas deste grupo.

Observando-se a figura 32, podemos encontrar variações em praticamente todas as posições médias dos marcos anatômicos para os dois grupos de abelhas africanizadas, o que nos permite diferenciá-los. Apesar de pequenas, as variações de todos os marcos anatômicos, quando combinadas nos permitem diferenciar os grupos.

Com estes dados podemos observar uma informação adicional que se refere à quantidade de indivíduos necessários para a caracterização dos grupos de modo a conseguirmos uma identificação consistente de seus respectivos representantes. Esta foi a 
única análise da tese onde somente cinco abelhas por colméia foram utilizadas como base de referência para as subespécies puras de $A$. mellifera. As outras duas, tanto as populações brasileiras quanto com as amostras panamenhas tiveram sua base de comparação formada com 10 abelhas por colméia para cada uma das subespécies e foi justamente na análise relacionada com as mudanças temporais da população de Ribeirão Preto - SP que conseguimos as menores taxas de acerto na identificação das subespécies. Podemos concluir então que para a minimização da variabilidade dos grupos, a melhor amostragem para cada um dos grupos deve ser em torno de 10 abelhas por colméia. Ruttner (1988), em seu tratado sobre biologia e taxonomia do gênero Apis propõe o uso de 10 a 20 abelhas por colméia baseado no desvio padrão das medidas tomadas das diversas colméias. Já Hepburn \& Radloff (1998) propõe que o número de 10 indivíduos por colônia já é suficiente. Entretanto, trabalhos com abelhas africanizadas que utilizaram cinco operárias por colônia também apresentaram resultados muito bons (Diniz-Filho \& Malaspina, 1996; Rotta 1999; Francoy et al., 2006a; b). Desta maneira, esta análise serviu para nos ajudar a estabelecer um protocolo de amostragem e análise para futuros estudos, tendo em vista que os trabalhos apresentados nesta tese constituem os primeiros com fins de identificação populacional de $A$. mellifera.

Quando comparamos os resultados de morfometria geométrica com os resultados apresentados pelo ABIS, este último se mostra mais eficiente na discriminação dos grupos quando as análises discriminantes não lineares são utilizadas, com acertos próximos a 93\% e em torno dos $85 \%$ quando são utilizadas as funções discriminantes lineares, taxa esta parecida com as obtidas com as análises de morfometria geométrica. Infelizmente, o ABIS ainda não nos permite um acesso direto aos dados extraídos para a realização das análises discriminantes e, portanto, não nos permite uma análise de identificação por colônias, mas os contatos sobre esse assunto já foram feitos com o grupo de pesquisa que desenvolveu o software na Universidade de Bonn - Alemanha e esta nova função já está sendo desenvolvida, o que vai nos permitir atingir melhores taxas de identificação subespecíficas no futuro. Vale lembrar que os valores de identificação do ABIS já são extremamente altos 
se levarmos em consideração que o software se utiliza apenas de características extraídas das asas e trata de indivíduos, enquanto as técnicas tradicionais se utilizam de medidas de todo o corpo das abelhas e se utilizam de médias de indivíduos de mesma colônias para discriminação. Vale lembrar que o ABIS é ainda um sistema totalmente automatizado que analisa e identifica cada um dos indivíduos em menos de um minuto. Todo o processo de treinamento e aprendizagem pelo qual o software tem que passar precisa ser feito somente uma vez, o que proporciona um enorme avanço em termos de identificação das subespécies deste grupo. Uma análise adicional envolvendo a identificação de todas as subespécies de $A$. mellifera com a utilização do ABIS está sendo realizada neste momento e os resultados devem ser obtidos em breve.

Quando tratamos as mudanças populacionais na população do Panamá, encontramos a mesma topologia do dendograma construído a partir das deformações relativas para as populações temporais de Ribeirão Preto, com a única diferença sendo que no lugar das populações de Ribeirão Preto aparecem as populações do Panamá.

A taxa de acerto nas identificações dos grupos analisados com morfometria tradicional fica na casa dos $84 \%$ quando utilizados os indivíduos (Tabela 31) e $81 \%$ quando utilizadas as colônias (Tabela 34). Novamente, a maior taxa de erro fica na população com maiores sinais de hibridização recente, ou seja, a população de 1982. Assim como a população de Ribeirão Preto de 1968 , esta população mostra sinais de hibridização evidenciados pelos dados de DNA mitocondrial e também por morfometria tradicional. Como as colônias devem apresentar diferentes graus de contribuição genética das subespecies formadoras nas abelhas de 1982, uma maior variabilidade dos dados é encontrada nas abelhas do início do processo de africanização panamenho, dificultando sua identificação pelas técnicas de morfometria geométrica.

A análise das formas médias das asas das duas populações africanizadas do Panamá não mostra grandes diferenças, o que explica as altas taxas de confusão entre os indivíduos dos dois grupos (Tabelas 31 e 34). 
Novamente, o ABIS é mais eficiente na discriminação dos grupos quando estes são avaliados por análises discriminantes não lineares, com as taxas de acerto ficando na casa dos $94 \%$, indicando uma maior eficiência deste software na identificação dos grupos. Estes resultados se mostram muito similares aos apresentados pelo ABIS na análise temporal das populações de Ribeirão Preto.

Ao observarmos as distâncias de Mahalanobis entre as duas populações atuais de abelhas africanizadas que foram analisadas temporalmente, podemos perceber que as distâncias entre as populações atuais e as subespécies aumentam quando comparadas com as mesmas distâncias das populações antigas. Isso indica que as populações africanizadas adquirem um perfil morfométrico distinto daqueles apresentados por suas subespécies formadoras, reforçando seu caráter único e rechaçando a idéia de que as populações Neotropicais de $A$. mellifera sejam simples populações de $A$. $m$. scutellata que se estabeleceram no Novo Mundo (para revisão sobre o assunto, ver Schneider et al., 2004a). 


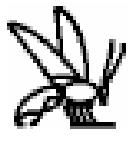

Conclusões

e Considerações Finais 
De uma maneira geral, este trabalho avalia o atual status de variabilidade de DNA mitocondrial e também de morfometria de asa de populações Neotropicais de Apis mellifera, introduzindo duas novas metodologias de análise morfométrica inéditas em estudos com abelhas africanizadas. Destes dados, alguns pontos merecem destaque como sendo inovadores ou confirmando outras hipóteses já levantadas em outros trabalhos:

- As abelhas africanizadas apresentam um gradiente de tamanho no sentido norte-sul do país, sendo que as abelhas maiores se encontram na região sul e as menores na região norte e nordeste do Brasil;

- Menos de $1 \%$ das colônias brasileiras atuais estudadas neste trabalho apresentam DNA mitocondrial de origem européia, indicando uma quase que completa substituição destes marcadores por DNA mitocondrial de origem africana;

- Os padrões de venação de asa das abelhas do Brasil apresentam-se mais parecidos com os padrões de $A$. m. scutellata do que com os padrões apresentados pelas outras subespécies. Entretanto, apesar desta maior similaridade, as abelhas africanizadas podem ser distinguidas das abelhas africanas com base nos dados gerados neste trabalho, o que indica que tais abelhas apresentam um perfil morfométrico único;

- As novas metodologias de morfometria geométrica e também o software ABIS mostraram resultados promissores na discriminação das subespécies de $A$. mellifera, tópico este que merece mais atenção em trabalhos futuros. Entretanto, devido ao alto grau de fluxo gênico entre as populações de abelhas africanizadas, nenhuma das duas metodologias se mostrou adequada para a identificação das populações de abelhas de acordo com sua localidade de origem;

- Apesar de apresentar padrões de DNA mitocondrial e de isoenzimas típicos de $A$. m. ligustica, as abelhas de Fernando de Noronha apresentam um perfil 
de morfometria de asa completamente distinto desta subespécie, sendo necessário que este cuidado seja levado em conta em trabalhos futuros envolvendo a morfometria destas abelhas;

- A população de Ribeirão Preto sofreu diversas mudanças no seu perfil morfométrico e de DNA mitocondrial, apresentando diversas diferenças quando comparadas as populações de 1968 e 2002;

- O mesmo aconteceu com as populações panamenhas de 1982 e 2006, com a diferença que a população de 1982 era uma população selvagem enquanto a população de Ribeirão Preto de 1968 era uma população estabelecida em um apiário experimental. É provável que os dados das populações panamenhas reflitam melhor os acontecimentos na natureza do que os dados das populações de Ribeirão Preto.

Certamente que ainda restam muitas questões em aberto quanto à variabilidade genética e morfológica das populações africanizadas, mas este trabalho apresenta um ama contribuição no sentido de avaliar por quatro metodologias diferentes um alto número de populações de abelhas $A$. mellifera da região Neotropical, abrindo as portas para a aplicação de duas novas metodologias nunca dantes utilizadas nestas abelhas. 
Referências Bibliográficas 
ARIAS, M. C.; BRITO, R. M.; FRANCISCO, F. O.; MORETTO, G.; DE OLIVEIRA, F. F.; SILVESTRE, D. \& SHEPPARD, W. S. 2006. Molecular markers as a tool for population and evolutionary studies of stingless bees. Apidologie 37 259-274.

AVISE, J. C.; ARNOLD, J.; BELL, K. M.; BERMINGHAM, F.; LAMB, T.; NEIGEL, J. B.; REEB, C. A. \& SAUNDERS, N. C. 1987. Intraespecific phylogeography: the mitochondrial DNA bridge between population genetics and systematics. Annual Review of Ecological Systems 18489 - 522.

BERGMANN, C. 1847. Ueber die Verhaltnisse der Warmeokonomie der Thiere zu ihrer Grosse. Göttinger Studien 3 595-708.

BITONDI, M. M. G. \& MESTRINER, M. A. 1983. Esterase Isozymes of Apis-mellifera Substrate and Inhibition Characteristics, Developmental Ontogeny, and Electrophoretic Variability. Biochemical Genetics 21 985-1002.

BOOKSTEIN, F. L. 1989. Principal Warps - Thin-Plate Splines and the Decomposition of Deformations. Ieee Transactions on Pattern Analysis and Machine Intelligence 11 567-585.

BOOKSTEIN, F. L. 1991 Morphometric tools for landmark data. Cambridge: Cambridge University Press

BOREHAM, M. M. \& ROUBIK, D. W. 1987. Population change and control of Africanized honeybees in the Panama Canal area. Bulletin of the Entomological Society of America 33 34-39. 
BRUCKNER, D. 1976. The Influence of Genetic Variability on Wing Symmetry in Honeybees (Apis mellifera). Evolution 30 100-108.

BUCO, S. M.; RINDERER, T. E.; SYLVESTER, H. A.; COLLINS, A. M.; LANCASTER, V. A. \& CREWE, R. M. 1987. Morphometric Differences between South-American Africanized and South-African (Apis-Mellifera-Scutellata) HoneyBees. Apidologie 18 217-222.

CHALINE, N.; RATNIEKS, F. L. W. \& BURKE, T. 2002. Anarchy in the UK: Detailed genetic analysis of worker reproduction in a naturally occurring British anarchistic honeybee, Apis mellifera, colony using DNA microsatellites. Molecular Ecology 11 $1795-1803$.

CLARKE, K. E.; RINDERER, T. E.; FRANCK, P.; QUEZADA-EUAN, J. G. \& OLDROYD, B. P. 2002. The Africanization of honeybees (Apis mellifera L.) of the Yucatan: A study of a massive hybridization event across time. Evolution 56 14621474.

CLARKE, K. E.; OLDROYD, B. P.; JAVIER, J.; QUEZADA-EUAN, G. \& RINDERER, T. E. 2001. Origin of honeybees (Apis mellifera L.) from the Yucatan peninsula inferred from mitochondrial DNA analysis. Molecular Ecology 10 1347-1355.

COLLET, T.; FERREIRA, K. M.; ARIAS, M. C.; SOARES, A. E. E. \& DEL LAMA, M. A. 2006. Genetic structure of Africanized honeybee populations (Apis mellifera L.) from Brazil and Uruguay viewed through mitochondrial DNA COI-COII patterns. Heredity 97 329-335. 
CONTEL, E. P. B.; MESTRINER, M. A. \& MARTINS, E. 1977. Genetic-Control and Developmental Expression of Malate-Dehydrogenase in Apis mellifera. Biochemical Genetics 15 859-876.

CORNUET, J. M. \& GARNERY, L. 1991. Mitochondrial DNA variability in honeybees and it's phylogeographic implications. Apidologie 22627 - 642.

CRANE, E. 1999 The world history of beekeeping and honey hunting. London: Ducksworth. $712 \mathrm{p}$

CREMONEZ, T.; DEJONG, D. \& BITONDI, M. M. G. 1998. Quantification of hemolymph proteins as a fast method for testing protein diets for honey bees (Hymenoptera: Apidae). Journal of Economical Entomology 91 1284-1289.

CRISTINO, A. S. 2003 Aspectos reprodutivos envolvidos no processo de africanização das abelhas Apis mellifera no Brasil. Dissertação apresentada à FMRP, USP, Ribeirão Preto. 99p.

CROZIER, R. H. \& CROZIER, Y. C. 1993. The mitochondrial genome of the honeybee Apis mellifera: complete sequence and genome organization. Genetics 13397 - 117.

DALY, H. V., BALLING, S. S. 1978. Identification of Africanized honeybees in the Western Hemisphere by discriminat analysis. Journal of Kansas Entomological Society 51 857-869. 
DALY, H. V., HOELMER, K., NORMAN, P., ALLEN, T. 1982. Computer assisted measurement and identification of honey bees. Annals of the Entomological Society America 75 591-594.

DANKA, R. G.; HELLMICH, R. L. \& RINDERER, T. E. 1992. Nest Usurpation, Supersedure and Colony Failure Contribute to Africanization of Commercially Managed European Honey-Bees in Venezuela. Journal of Apicultural Research 31 119123.

DEL LAMA, M. A.; MESTRINER, M. A. \& PAIVA, J. C. A. 1985. Est-5 and Pgm1 New Polymorphisms in Apis mellifera. Revista Brasileira de Genetica 8 17-27.

DEL LAMA, M. A.; FIGUEIREDO, R. A.; SOARES, A. E. E. \& DEL LAMA, S. N. 1988. Hexoquinase polymorphism in Apis mellifera and its use for africanized honeybee identification. Revista Brasileira de Genetica 11 287-297.

DEL LAMA, M. A., LOBO, J. A., SOARES, A. E. E., DEL LAMA, S. N. 1990. Genetic differentiation estimated by isozymic analysis of Africanized honey bee populations from Brazil and from Central America. Apidologie 21 271-280.

DEL LAMA, M. A.; SOUZA, R. O.; DURAN, X. A. A. \& SOARES, A. E. E. 2004. Clinal variation and selection on $\mathrm{MDH}$ allozymes in honeybees in Chile. Hereditas 140 149-153.

DEL LAMA, M. A.; SOARES, A. E. E.; COLLET, T. \& FERREIRA, K. M. 2006 Racial admixture and level of interpopulation differentiation among South American 
Africanized honeybee (Apis mellifera L.) populations. Anais do VII Encontro sobre Abelhas. Ribeirão Preto. 84-89 p.

DILLON, M. E.; FRAZIER, M. R. \& DUDLEY, R. 2006. Into thin air: Physiology and evolution of alpine insects. Integrative and Comparative Biology 46 49-61.

DINIZ, J. A. F. \& MALASPINA, O. 1996. Geographic variation of Africanized honey bees (Apis mellifera L) in Brazil: Multivariate morphometrics and racial admixture. Brazilian Journal of Genetics 19 217-224.

DINIZ, N. M.; SOARES, A. E. E.; SHEPPARD, W. S. \& DEL LAMA, M. A. 2003. Genetic structure of honeybee populations from southern Brazil and Uruguay. Genetics and Molecular Biology 26 47-52.

DOBIGNY, G.; BAYLAC, M. \& DENYS, C. 2002. Geometric morphometrics, neural networks and diagnosis of sibling Taterillus species (Rodentia, Gerbillinae). Biological Journal of the Linnean Society 77 319-327.

DRAUSCHKE, M., V. STEINHAGE, A. POGODA, S. MÜLLER, T. M. FRANCOY, AND D. WITTMANN. 2007. Reliable Biometrical Analysis in Biodiversity Information Systems. pp. 25-36 in Fred, A. \& Jain, A. K. eds. Proceedings of the 7th International Workshop on Pattern Recognition in Information Systems - PRIS 2007, Funchal, Portugal.

DUPRAW, E. J. 1964. Non-Linnean Taxonomy. Nature 202849 - 852. 
DUPRAW, E. J. 1965a. Non-Linnean taxonomy and the systematics of honeybees. Systematics Zooogy. 141 - 24.

DUPRAW, E. J. 1965b. The recognition and handling of honeybee specimens in nonLinnean taxonomy. Journal of Apicultural Research 471 - 84.

ESTOUP, A., SOLIGNAC, M., HARRY, M. CORNUET, J. M. 1993. Characterization of (GT)n and (CT)n microsatellites in two insect species: Apis melifera and Bombus terrestris. Nucleic Acids Research 211427 - 1431.

ESTOUP, A., SOLIGNAC, M., CORNUET, J. M. 1994. Precise assessment of the number of patriline and of genetic relatedness in honeybee colonies. Proccedings of the. Royal Society of London B 258 1-7.

ESTOUP, A.; GARNERY, L.; SOLIGNAC, M. \& CORNUET, J. M. 1995. Microsatellite Variation in Honey-Bee (Apis-Mellifera L) Populations - Hierarchical GeneticStructure and Test of the Infinite Allele and Stepwise Mutation Models. Genetics 140 679-695

FINK, W. L. \& ZELDTICH, M. L. 1995. Phylogenetics analysis of ontogenetic chape transformations: a reassessment of the piranha genus Pygocentrus (Teleostei). Systematics Biology 44 343-360.

FRANCK, P.; GARNERY, L.; SOLIGNAC, M. \& CORNUET, J. M. 1998. The origin of west European subspecies of honeybees (Apis mellifera): New insights from microsatellite and mitochondrial data. Evolution 52 1119-1134. 
FRANCK, P.; GARNERY, L.; SOLIGNAC, M. \& CORNUET, J. M. 2000. Molecular confirmation of a fourth lineage in honeybees from the Near East. Apidologie 31 167180.

FRANCOY, T. M.; PRADO, P. P. R.; GONCALVES, L. S.; COSTA, L. D. \& DE JONG, D. 2006a. Morphometric differences in a single wing cell can discriminate Apis mellifera racial types. Apidologie 37 91-97.

FRANCOY, T. M.; GONCALVES, L. S. \& WITTMANN, D. 2006b. Changes in the patterns of wing venations of Africanized honey bees over time. Anais do VII Encontro sobre Abelhas. Ribeirão Preto. 173-177 p.

FRIESS, M. 2003. An application of the relative warps analysis to problems in human paleontology - with notes on raw data quality. Image Anal Stereol 22 63-72.

GHADERI, A.; ADAMS, M. W. \& NASSIB, A. M. 1984. Relationship between genetic distance and heterosis for yield and morphological traits in dry edible bean and fava bean. Crop Science 14 24-27.

GOETZE, G. 1940 Die beste Biene. Leipzig: Liedlof Loth Michaelis

GONÇALVES, L. S. 1970 Análise genética do cruzamento entre Apis mellifera ligustica e Apis mellifera adansonii. Escolha e análise genética de caracteres morfológicos da cabeça e do tórax. (Doutoramento). Tese de doutoramento apresentada à Faculdade de Medicina de Ribeirão Preto, USP, Ribeirão Preto. 141 p. 
GONÇALVES, L. S. 1974. The introduction of the African Bees (Apis mellifera adansonii) into Brazil and some comments on their spread in South America. American Bee Journal 114414 - 415, 419.

GONÇALVES, L. S. 1975. A abelha, símbolo do bem estar. Anais do $3^{\circ}$ Congresso Brasileiro de Apicultura. Piracicaba. pp. 43-53.

GONÇALVES, L. S. 1994. Africanização das abelhas nas Américas, impactos e perspectivas de aproveitamento do material genético. Anais do $9^{\circ}$ Congresso Brasileiro de Apicultura. Candelária, 1992. 35-41 p.

GONÇALVES, L. S. 2004. The big chalenge: Development of beekeeping with Africanized honey bees in northeast Brazil. Proceedings of the $8^{\text {th }}$ International Conference on Tropical Bees and VII Encontro sobre Abelhas. Ribeirão Preto. 241$247 \mathrm{p}$

HABERL, M. \& TAUTZ, D. 1998. Sperm usage in honey bees. Behavioral Ecology and Sociobiology 42 247-255.

HALL, H. G. \& MURALIDHARAN, K. 1989. Evidence from mitochondrial DNA that African honey bee spread as continuous maternal lineages. Nature 339211 - 213.

HALL, H. G. \& SMITH, D. R. 1991. Distinguishing African and European Honeybee Matrilines Using Amplified Mitochondrial-DNA. Proceedings of the National Academy of Sciences of the United States of America 88 4548-4552. 
HARD, J. J.; BEREJIKIAN, B. A.; TEZAK, E. P.; SCHRODER, S. L.; KNUDSEN, C. M. \& PARKER, L. T. 2000. Evidence for morphometric differentiation of wild and captively reared adult coho salmon: a geometric analysis. Environmental Biology of Fishes $\mathbf{5 8}$ 61-73.

HARRISSON, J. F. \& HALL, H. G. 1993. African-European honeybee hybrids have low nonintermediate metabolic capacities. Nature 363 258-260.

HEPBURN, H. R. \& RADLOFF, S. 1998 Honeybees of Africa. Berlin: Springer Verlag. 370p.

HUGHES, C. R. \& QUELLER, D. C. 1993. Detection of highly polymorphic microsatellite loci in a specie with little allozyme polymorfism. Molecular Ecology 2 $131-137$

INNIS, M. A., GELFAND, D. H., SNINSKY, J. J., WHITE, T. J. 1990 PCR Protocols. San Diego: Academic Press

KERR, W. E. 1957. Introdução de abelhas africanas no Brasil. Brasil Apícola 3 211-213.

KERR, W. E. 1967. The history of the introduction of africanized bees to Brazil. South African Bee Journal 39 3-5.

KERR, W. E. \& PORTUGAL-ARAÚJO, V. 1958. Raças de abelhas da Africa. Garcia de Orta 6 53-59. 
KERR, W. E.; GONÇALVES, L. S.; STORT, A. C. \& BUENO, D. 1967 Biological and genetical information on Apis mellifera adansonii. Proceedings of the $21^{\text {st }}$ International Apiculture Congress APIMONDIA. Maryland. 76 p.

KERR, W. E.; GONCALVES, L. S.; BLOTTA, L. F. \& MACIEL, H. B. 1970 Comparative Biology of Italian Bees (Apis mellifera ligustica), Africanized Bees (Apis mellifera adansonii), and their hybrids. Anais do $1^{\circ}$ Congresso Brasileiro de Apicultura. Florianópolis - SC. 151-185 p.

KERR, W. E., DEL RIO, S. L. BARRIONUEVO, M. D. 1982. The southern limits of the distribution of the Africanized honey bees in South America. American Bee Journal $122196-198$.

Kumar, S.; Tamura K., Jakobsen, I. B. \& Nei, M. 2001. MEGA2: Molecular Evolutionary Genetics Analysis software, Arizona State University, Tempe, Arizona, USA.

LOBO, J. A., DEL LAMA, M. A., MESTRINER, M. A. 1989. Population differentiation and racial admixture in the Africanized honey bee (Apis melifera L.). Evolution 43794 802.

LOBO, J. A. \& KRIEGER, H. 1992. Maximum-likelihood estimates of gene frequencies and racial admixture in Apis melifera L. (Africanized honeybees). Heredity 68441 - 448.

LOPER, G. M. \& DANKA, R. G. 1991. Pollination Tests with Africanized Honey-Bees in Southern Mexico, 1986-88. American Bee Journal 131 191-193. 
MALAGODI, M.; KERR, W. E. \& SOARES, A. E. E. 1986. Introdução de abelhas na Ilha de Fernando de Noronha. 2. População de Apis mellifera ligustica. Ciência e Cultura 38 1700-1704.

MARTINS, E.; MESTRINER, M. A. \& CONTEL, E. P. B. 1977. Alcohol-Dehydrogenase Polymorphism in Apis mellifera. Biochemical Genetics 15 357-366.

MCMULLAN, J. B. \& BROWN, M. J. F. 2006. The influence of small-cell brood combs on the morphometry of honeybees (Apis mellifera). Apidologie 37 665-672.

MENDES, M. F. M. 2006 Variabilidade inter e intra-populacional de Nannotrigona testaceicornis analisadas com técnicas de morfometria geométrica. Monografia apresentada a FFCLRP USP, Ribeirão Preto. 55 p.

MESTRINER, M. A. 1969. Biochemical Polymorphisms in Bees (Apis mellifera ligustica). Nature 223 188-189.

MESTRINER, M. A. \& CONTEL, E. P. B. 1972. P-3 and Est Loci in Honeybee Apis mellifera. Genetics 72 733-738.

MICHENER, C. D. 1975. The Brazilian bee problem. Annual Review of Entomology 20390 416.

MONTEIRO, L. R. \& REIS, S. F. 1999 Princípios de Morfometria Geométrica. Ribeirão Preto: Holos Editora. 198 p. 
MORITZ, R. F. A.; HAWKINS, C. F.; CROZIER, R. H. \& MACKINLEY, G. A. 1986. A mitochondrial DNA polymorphisms in honeybees (Apis mellifera L.). Experientia 42 $322-324$

NAYLOR, G. J. P. 1996. Can partial warp scores be used as cladistic characters? In: MARCUS, L. F.; CORTI, M.; LOY, A.; NAYLOR, G. \& SLICE, D. (Eds.). Advances in Morphometrics. New York: Plenum Publishing Corp., p. 519-530

NOGUEIRA-NETO, P. 1972. Notas sobre a história da apicultura brasileira. In: CAMARGO, J. M. F. (Ed.). Manual de Apicultura: Agronômica Ceres,p. 17-32

PALMER, A. R. 1994. Fluctuating asymmetry analyses: a primer. In: MARKOW, T. A. (Ed.). Developmental Instability: Its Origins and Evolutionary Implications. Dordrecht: Kluwer, p. 335-364

PAMILO, P. \& CROZIER, R. H. 1982. Measuring Genetic Relatedness in NaturalPopulations - Methodology. Theoretical Population Biology 21 171-193.

PAMILO, P., GERTSCH, P., THOREN, P., SEPPA, P. 1997. Molecular population genetics of social insects. Annual Review of Ecological Systems 28 1-25.

PAMILO, P.; ROSENGREN, R.; VEPSALAINEN, K.; VARVIOAHO, S. L. \& PISARSKI, B. 1978. Population-Genetics of Formica Ants . 1. Patterns of Enzyme Gene Variation. Hereditas 89 233-248. 
PERUQUETTI, R. C. 2003. Variação do tamanho dos machos de Eulaema nigrita (Hymenoptera, Apidae, Euglossini). Resposta materna à flutuação de recursos?Revista Brasileira de Zoologia 20 207-212.

PICCIRILO, G. A. \& DE JONG, D. 2003. The influence of brood comb cell size on the reproductive behavior of the ectoparasitic mite Varroa destructor in Africanized honey bee colonies. Genetics and Molecular Research 2 36-42.

PINTO, M. A.; SHEPPARD, W. S.; JOHNSTON, J. S.; RUBINK, W. L.; COULSON, R. N.; SCHIFF, N. M.; KANDEMIR, I. \& PATTON, J. C. 2007. Honey bees (Hymenoptera : Apidae) of African origin exist in non-Africanized areas of the Southern United States: Evidence from mitochondrial DNA. Annals of the Entomological Society of America 100 289-295.

PIRES, H. H. R.; BARBOSA, S. E.; MARGONARI, C.; JURBERG, J. \& DIOTAIUTI, L. 1998. Variations of the external male genitalia in three populations of Triatoma infestans Klug, 1834. Memorias do Instituto Oswaldo Cruz 93 479-483.

PLOWRIGHT, R. C. \& JAY, S. C. 1977. Size Determination of Bumble Bee Castes (Hymenoptera-Apidae). Canadian Journal of Zoology-Revue Canadienne De Zoologie 55 $1133-1138$.

QUELLER, D. C., STRASSMANN, J. E., HUGHES, C. R. 1993. Microsatellites and kinship. Trends in Ecology and Evolution 8 285-288. 
QUEZADA-EUAN, J. J. G.; PEREZ-CASTRO, E. E. \& MAY-ITZA, W. D. 2003. Hybridization between European and African-derived honeybee populations (Apis mellifera) at different altitudes in Peru. Apidologie 34 217-225.

RAY, C. 1960. The application of Bergmann's and Allen's rules to the poikilotherms. Journal of Morphology 106 85-108.

RIBEIRO, M. F. 1994. Growth in Bumble Bee Larvae - Relation between Development Time, Mass, and Amount of Pollen Ingested. Canadian Journal of Zoology-Revue Canadienne De Zoologie 72 1978-1985.

RINDERER, T. E. 1986. Africanized Bees - an Overview. American Bee Journal 126 98-\& .

RINDERER, T. E.; SYLVESTER, H. A.; BROWN, M. A.; VILLA, J. D.; PESANTE, D. \& COLLINS, A. M. 1986. Field and simplified techniques for identifying africanized and european honey-bees. Apidologie 1733 - 48.

RINDERER, T. E.; DALY, H. V.; SYLVESTER, H. A.; COLLINS, A. M.; BUCO, S. M.; HELLMICH, R. L. \& DANKA, R. G. 1990. Morphometric Differences among Africanized and European Honey-Bees and Their F1 Hybrids (Hymenoptera, Apidae). Annals of the Entomological Society of America 83 346-351.

RINDERER, T. E.; OLDROYD, B. P. \& SHEPPARD, W. S. 1993a. Africanized honeybees in the United States. Scientific American 26952 - 58.

RINDERER, T. E.; BUCO, S. M.; RUBINK, W. L.; DALY, H. V.; STELZER, J. A.; RIGGIO, R. M. \& BAPTISTA, F. C. 1993b. Morphometric Identification of 
Africanized and European Honey-Bees Using Large Reference Populations. Apidologie 24 569-585.

ROHLF, F. J. 1993 Relative warp analysis and an example of its aplication to mosquito wings. Madrid: Museo de Ciencias Naturales. 131-159 p.

ROHLF, F. J. 1996. Morphometric spaces, shape components and the effect of linear transformations. In: MARCUS, L. F.; CORTI, M.; LOY, A.; NAYLOR, G. \& SLICE, D. (Ed.). Advances in Morphometrics. New York: Plenum Publishing Corp.,p. $117-130$

ROHLF, F. J. 1998. On applications of geometric morphometrics to studies of ontogeny and phylogeny. Systematic Biology 47 147-158.

ROHLF, F. J. 1999. Shape statistics: Procrustes superimpositions and tangent spaces. Journal of Classification 16 197-223.

ROHLF, F. J. 2004. tpsUtil, versão 1.33. Department of Ecology and Evolution, State University of New York, Stony Brook.

ROHLF, F.J. 2005a. tpsDig, versão 2.04. Department of Ecology and Evolution, State University of New York, Stony Brook.

ROHLF, F.J. 2005b. tpsRelw, versão 1.42. Department of Ecology and Evolution, State University of New York, Stony Brook. 
ROHLF, F. J. \& MARCUS, L. F. 1993. A Revolution in Morphometrics. Trends in Ecology \& Evolution 8 129-132.

ROTH, V. \& STEINHAGE, V. Nonlinear Discriminant Analysis Using Kernel Functions. Boletim informativo da Universität Bonn. Bonn. 1999

ROTTA, I. T. 1999 Análise aloenzimática, morfométrica e dos padrões do DNA mitocondrial das abelhas Africanizadas do Brasil. Tese apresentada à Universidade Federal de São Carlos, São Carlos. 114 p.

ROUBIK, D. W. 1982. Africanized honey bee confirmed in Panama. American Bee Journal 122322.

ROULSTON, T. H. \& CANE, J. H. 2002. The effect of pollen protein concentration on body size in the sweat bee Lasioglossum zephyrum (Hymenoptera: Apiformes). Evolutionary Ecology 16 49-65.

RUTTNER, F. 1988 Biogeography and taxonomy of honeybees. Berlin: Springer. 284 p.

RUTTNER, F. 1992 Naturageschichte der Honigbienen. München: Ehrenwirth Verlag. 357 p.

RUTTNER, F.; TASSENCOURT, L. \& LOUVEAUX, J. 1978. Biometrical statistical analysis of the geographic variability of Apis mellifera L. 1. Material and Methods. Apidologie 9 363-381. 
SANGUINETTI, C., DIAS NETO, E., SIMPSON, A. J. G. 1994. Rapid silver staining and recovery of PCR products separeted on polyacrylamide gels. Biotehniques 17209 214.

SCHNEIDER, S. S.; LEAMY, L. J.; LEWIS, L. A. \& DE GRANDI-HOFFMAN, G. 2003. The influence of hybridization between African and European honeybees, Apis mellifera, on asymmetries in wing size and shape. Evolution 57 2350-2364.

SCHNEIDER, S. S.; HOFFMAN, G. D. \& SMITH, D. R. 2004a. The African honey bee: Factors contributing to a successful biological invasion. Annual Review of Entomology $49351-376$.

SCHNEIDER, S. S.; DEEBY, T.; GILLEY, D. C. \& DEGRANDI-HOFFMAN, G. 2004b. Seasonal nest usurpation of European colonies by African swarms in Arizona, USA. Insectes Sociaux 51 359-364.

SCHRÖDER, S.; DRESCHER, W.; STEINHAGE, V. \& KASTENHOLZ, B. 1995 An Automated Method for the Identification of Bee Species (Hymenoptera: Apoidea). Proceedings of the International Symposium on Conserving Europe's Bees: IBRA \& Linnean Society. 6-7 p.

SCHRÖDER, S.; WITTMANN, D.; DRESCHER, W.; ROTH, V.; STEINHAGE, V. \& CREMERS, A. B. 2006. The new key to bees: Automated Identification by image analysis of wings. In: KEVAN, P. \& IMPERATRIZ-FONSECA, V. L. (Ed.). Pollinating Bees. The conservation link between agriculture and nature.,p. 229-236 
SEGURA, J. A. L. 2000. Highly polymorphic DNA markers in an Africanized honey bee population in Costa Rica. Genetics and Molecular Biology 23 317-322.

SHEPPARD, W. S., RINDERER T. E., MAZZOLI J., STELZER J. A., SHIMANUKI H. 1991a. Gene flow between African- and European-derived honey bee populations in Argentina. Nature 321674 - 679.

SHEPPARD, W. S., SOARES, A. E. E., DE JONG, D., SHIMANUKI. 1991b. Hybrid status of honey bee populations near the historic origin of Africanization in Brazil. Apidologie 22643 - 652.

SHEPPARD, W. S.; ARIAS, M. C.; GRECH, A. \& MEIXNER, M. D. 1997. Apis mellifera ruttneri, a new honey bee subspecies from Malta. Apidologie 28 287-293.

SHEPPARD, W. S.; RINDERER, T. E.; GARNERY, L. \& SHIMANUKI, H. 1999. Analysis of Africanized honey bee mitochondrial DNA reveals further diversity of origin. Genetics and Molecular Biology 22 73-75.

SHEPPARD, W. S. \& SMITH, D. R. 2000. Identification of African-derived bees in the Americas: A survey of methods. Annals of the Entomological Society of America 93 159176.

SHEPPARD, W. S. \& MEIXNER, M. D. 2003. Apis mellifera pomonella, a new honey bee subspecies from Central Asia. Apidologie 34 367-375. 
SILVA, R. A. O. 2006 A morfometria geométrica e a diferenciação de espécies do gênero Plebeia (Apidae, Meliponini). Monografia apresentada à FFCLRP USP, Ribeirão Preto. $42 \mathrm{p}$.

SLICE, D. 1998. Morpheus. Department of Ecology and Evolution, State University of New York, Stony Brook.

SMITH, D. R. \& BROWN, W. M. 1990. Restriction endonuclease cleavage site and lenght polymorphisms in mitochondrial DNA of Apis mellifera mellifera and Apis mellifera carnica (Hymenoptera: Apidae). Annals of the Entomological Society of America 8381 - 88.

SMITH, D. R.; CRESPI, B. J. \& BOOKSTEIN, F. L. 1997. Fluctuating assimetry in the honey bee Apis mellifera: effects of ploidy and hybridization. Journal of Evolutionary Biology 10 551-574.

SMITH, F. G. 1961. The races of honeybees in Africa. Bee World 42 255-260.

STATSOFT, Inc. STATISTICA (data analysis software system), version 6. www.statsoft.com. 2001.

STEINHAGE, V.; KASTENHOLZ, B.; SCHRÖDER, S. \& DRESCHER, W. 1997 A Hierarchical Approach to Classify Solitary Bees Based on Image Analysis. XIX DAGM-Symposium. Braunschweig: Springer. 419-426 p.

STEINHAGE, V.; ARBUCKLE, T.; SCHRÖDER, S.; CREMERS, A. B. \& WITTMANN, D. 2001. ABIS: Automated Identification of Bee Species. BIOLOG Workshop, German Programme on Biodivserity and Global Change, Status Report 194-195. 
STORT, A. C. 1972 Estudo genético da agressividade em Apis mellifera. Tese apresentada à FMRP USP, Ribeirão Preto.

SUTHERLANDS, G. R. \& RICHARDS, R. I. 1995. Simple tandem DNA repeats and human gentic disease. PNAS U. S. A. 923636 - 3641.

TAYLOR, O. R. 1977. The past and possible future spread of Africanized honeybees in the Americas. Bee World 5819 - 30.

THOMPSON, D. W. 1917 On growth and form. London: Cambridge University Press. 753 p.

VERGARA, C.; DIETZ, A. \& DELEON, A. P. 1993. Female parasitism of European honey-Bees by Africanized honey-Bee swarms in Mexico. Journal of Apicultural Research 32 34-40.

WARRIOR, R. \& GALL, J. 1985. The Mitochondrial-DNA of Hydra attenuata and Hydra littoralis Consists of 2 Linear-Molecules. Archives Des Sciences 38 439-445.

WATKINS, W. S.; BAMSHAD, M. \& JORDE, L. B. 1995. Population genetics of trinucleotide repeat polymorphisms. Human Molecular Genetics 41485 - 1491.

WHITFIELD, C. W.; BEHURA, S. K.; BERLOCHER, S. H.; CLARK, A. G.; JOHNSTON, J. S.; SHEPPARD, W. S.; SMITH, D. R.; SUAREZ, A. V.; WEAVER, D. \& TSUTSUI, N. D. 2006. Thrice out of Africa: Ancient and recent expansions of the honey bee, Apis mellifera. Science 314 642-645. 
WILKINSON, R. H. 1992 Reading Egyptian art. London: Thames and Hudson

ZELDTICH, M. L.; FINK, W. L. \& SWIDERSKI, D. L. 1995. Morphometrics, homology and phylogenetics: quantified characters as synapomorphies. Systematics Biology 44 179-189. 